UCRL-CR-135687

S/C B505188

\title{
Rationale for Wind-Borne Missile Criteria for DOE Facilities
}

James R. McDonald, Ph.D., P.E.

September 1999

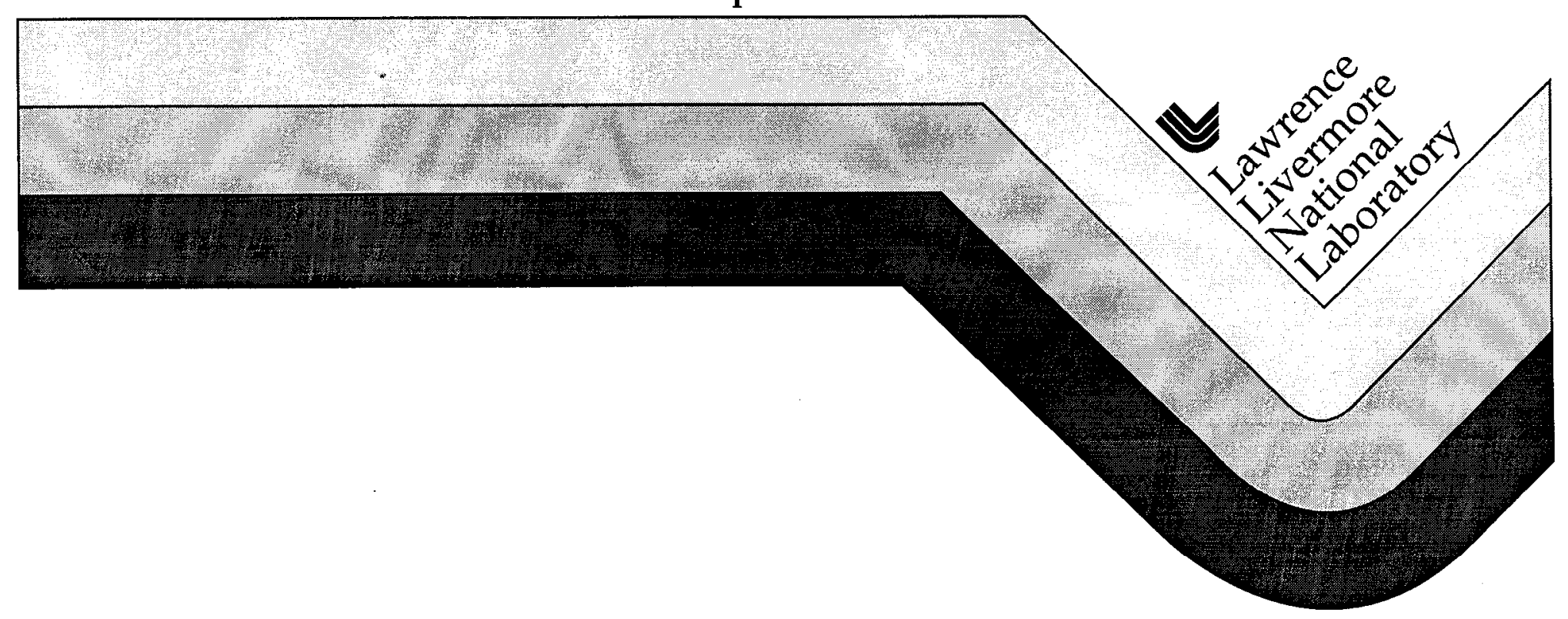




\section{DISCLAIMER}

Work performed under the auspices of the U.S. Department of Energy by Lawrence Livermore National Laboratory under contract number W-7405-ENG-48.

This document was prepared as an account of work sponsored by an agency of the United States Government. Neither the United States Government nor the University of California nor any of their employees, makes any warranty, express or implied, or assumes any legal liability or responsibility for the accuracy, completeness, or usefulness of any information, apparatus, product, or process disclosed, or represents that its use would not infringe privately owned rights. Reference herein to any specific commercial products, process, or service by trade name, trademark, manufacturer, or otherwise, does not necessarily constitute or imply its endorsement, recommendation, or favoring by the United States Government or the University of California. The views and opinions of authors expressed herein do not necessarily state or reflect those of the United States Government or the University of California, and shall not be used for advertising or product endorsement purposes. 


\title{
Rationale for Wind-Borne Missile Criteria for DOE Facilities
}

\author{
By \\ James R. McDonald, Ph.D., P.E. \\ Prepared for \\ Hazards Mitigation Center \\ Lawrence Livermore National Laboratory
}

September 1999

Institute for Disaster Research

Texas Tech University

Lubbock, Texas 


\section{FOREWORD}

This report is the culmination of more than 20 years of research by the author and colleagues at Texas Tech University. One of the first missiles studied was a 13.5-ft diameter by $20 \mathrm{ft}$ long steel tank that was transported by the Lubbock tornado of 1970 . News reports stated that the huge tank had flown through the air for more than 5 miles. Careful study by Texas Tech University personnel showed that the tank actually rolled and tumbled the stated distance and never rose more than a few feet above ground. The incident points to the need for very careful study of tornado missiles in the field. To date, Texas Tech University researchers through the Institute for Disaster Research have studied damage and documented missiles in more than 70 windstorm events, including hurricanes, tornadoes and high winds.

Support for preparation of this report was provided through Contract No. B235251 with Lawrence Livermore National Laboratory, Livermore, California. Dr. Robert C. Murray served as a technical monitor on the project. Dr. James R. McDonald was the Principal Investigator and Project Manager.

The author wishes to acknowledge the contributions of faculty and graduate students, who over the years performed the analyses and impact tests described in this report. Dr. Robert Bailey and Dr. Milton Smith designed and constructed the tornado missile cannon. Brad White performed impact tests on a number of CMU block walls; Peng- Hsiang Luan made estimates of missile speeds in tornadoes by means of trajectory simulations and Blair Nevins conducted impact tests and contributed to the development of the recommended DOE missile barrier criteria. 
Page No.

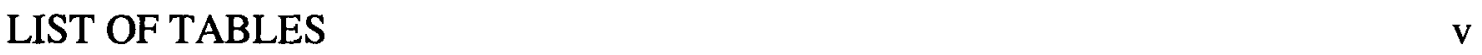

LIST OF FIGURES vii

\section{EXECUTIVE SUMMARY}

1. Introduction 1

1.1 Wind and Tornado Missiles 1

1.2 Objective and Scope of Study 2

1.3 DOE Approach to Natural Phenomena Hazards 3

$\begin{array}{lll}1.4 & \text { Background } & 7\end{array}$

2. Missile Classes Based on Field Observations of Missiles 12

$\begin{array}{ll}2.1 \text { Approach } & 13\end{array}$

$\begin{array}{ll}2.2 \text { Fujita-Scale } & 13\end{array}$

$\begin{array}{ll}2.3 \text { Missile Observations } & 17\end{array}$

$\begin{array}{ll}\text { 2.3.1 General Views of Damage } & 17\end{array}$

2.3.2 Examples of Individual Missiles $\quad 20$

2.4 Distribution of Timber Missiles $\quad 32$

$\begin{array}{ll}2.5 \text { Other Missiles } & 37\end{array}$

2.6 Missiles that Did Not Fly 38

2.7 Recommended Missiles $\quad 40$

$\begin{array}{lll}2.7 .1 & \text { Tornado Missiles } & 40\end{array}$

2.7.2 High Wind Missiles 41

3. Rationale for Missile Speeds and Heights (Computer Simulation of Tornado

$\begin{array}{ll}\text { Missile Trajectories) } & 43\end{array}$

3.1 Introduction 43

$\begin{array}{lll}3.2 & \text { Objectives } & 44\end{array}$

3.3 Requirements for Missile Trajectory Simulation 45

3.4 Literature Review 46

3.5 Factors Affecting Missile Trajectories 49

3.5.1 Tornado Wind-field Model 49

3.5.2 Dynamic Equations $\quad 51$

3.5.3 Aerodynamic Flight Parameter 53

3.5.4 Means of Injection $\quad 55$

3.6 Formulation of IDR Tornado Missile Trajectory Code 57

$\begin{array}{ll}\text { 3.6.1 Equations of Motion } & 58\end{array}$

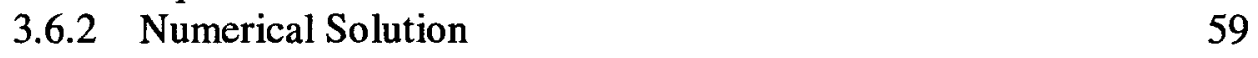

$\begin{array}{ll}\text { 3.6.3 Computer Code } & 60\end{array}$

$\begin{array}{ll}3.7 \text { Validation of IDR Computer Code } & 62\end{array}$

3.7.1 Bossier City, Louisiana, Tornado 63

3.7.2 Comparison with NBS Trajectory Model 66 
3.8 Estimates of Missile Impact Speeds from Trajectory Simulations $\quad 69$

3.8.1 Description of Method $\quad 69$

$\begin{array}{ll}\text { 3.8.2 Distribution of Missiles } & 72\end{array}$

3.8.3 Sample Trajectory Calculations $\quad 74$

3.8.4 Rational for Impact Speed Recommendations $\quad 87$

4. Tornado Missile Impact Criteria $\quad 89$

4.1 Introduction $\quad 89$

4.2 Review of Previous Research 92

4.2.1 Previous Research on 2x4 Timber Plank Impacts 92

4.2.2 Previous Research on 3-Inch Diameter Steel Pipe Impacts 97

4.2.3 Impact Equations 97

$\begin{array}{lll}4.3 & \text { Design of Experiment } & 100\end{array}$

4.3.1 Reinforced Control Panels 103

4.3.2 Reinforced Masonry Panels 106

$\begin{array}{lll}4.4 & \text { Experimental Facility } & 107\end{array}$

4.4.1 Missile Launcher $\quad 110$

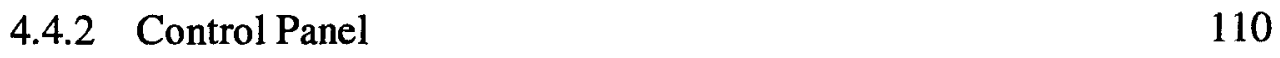

4.4.3 Reaction Frame 116

4.4.4 Missile Velocity Measurement System 116

4.5 Material Properties and Procedures 119

4.5.1 Construction of Test Panels 119

4.5.2 Material Properties 120

4.5.3 Testing Procedures 121

$\begin{array}{lll}4.5 .4 & \text { Prelaunch } & 121\end{array}$

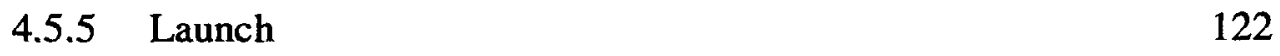

4.5.6 Postlaunch 122

4.5.7 Data Collection 123

4.5.8 Quality Assurance 123

$\begin{array}{lll}4.6 & \text { Test Results } & 124\end{array}$

4.6.1 Six-inch Reinforced Concrete Slabs 124

4.6.2 Eight-Inch Reinforced Concrete Panels 125

4.6.3 Nine-Inch Reinforced Concrete Pancls 135

4.6.4 Concrete Reinforcing Panels 145

4.6.5 Reinforced Masonry Panels 154

4.7 Recommended Missile Barriers $\quad 155$

4.7.1 Barriers for Performance Category 3 167

4.7.2 Barriers for Performance Category $4 \quad 168$

REFERENCES

APPENDIX A:

APPENDIX B:

APPENDIX C:

APPENDIX D:

APPENDIX E:

APPENDIX F:

APPENDIX G:

APPENDIX H:

Pressure Versus Vclocity Calculations

170

Material Properties

Data Sheets

2x4 Timber Missile Impacts on Reinforced Concrete

Percent Steel Calculations for Reinforced Concrete

Calibration Timers

Data Sheets

2x4 Timber Missile Impacts on Reinforced Concrete 
APPENDIX I: $\quad$ Percent Steel Calculations for Reinforced Concrete Panels APPENDIX J: $\quad$ Calibration of Timbers 


\section{IJST OF TABLES}

Table

1.1 Summary of Minimum Wind Design Criteria for DOE SSCs

Page No.

1.2 Tornado Design Criteria for Nuclear Power Plants: Reg. Guide 1.76

1.3 Tornado Missile Criteria for Nuclear Power Plants 9

1.4 Summary of Results of PRAs for Selected Nuclear Power Plants:

Tornado Missiles

2.1 Fujita Scale Classification of Tornadoes Based on Damage

2.2 Tornado Design Wind Speed at DOE Sites

2.3 Tornado Missile Data

2.4 Data Summary for Wood Missiles

2.5 Confidence Limits and Significance Test Results

3.1 Tornado Missile Flight Parameters

3.2 Comparison of Maximum Horizontal Missile Speed from NBS and IDR Models

3.3 Number of Missiles Distributed Across Path of Each F-Scale Tornado

3.4 Results of Trajectory Calculations (2x4 Timber Plank in F3 Tornado)

3.5 Frequency Histogram of 2x4 (15 lb) Timber Missile Released in F3 Tornado 81

3.6 Results of Trajectory Calculations for 3-in dia. Steel Pipe in F5 Tornado 86

3.7 Frequency Histogram of 3-in dia. Steel Pipe Missile Released in F5 Tornado 87

4.1 Impact Speed to Perforate Typical Residential Wall Panels, $2 \times 4$ Timber Plank

4.2 Impact Speed to Perforate CMU Walls

4.3 Tornado Missiles Impact Test on Reinforced Concrete Panels (Texas Tech University, 1989) 
4.5 Reinforced Masonry Barrier Schedule

4.6 Reinforcing Arrangement Comparison 


\section{LIST OF FIGURES}

Figure

Page No.

2.1 Aerial View of Damage Caused by Wichita Falls, Texas, Tornado (F-4, 1979) 18

2.2 Missiles and Debris from Damaged Shopping Center Caused by

Wichita Falls, Texas, Tornado (F-4, 1979)

2.3 Courtyard at McNeil Junior High, Wichita Falls, Texas (F-4, 1979)

2.4 Heavily Damaged Commercial Building in Bossier City, Louisiana (F-4, 1979)

2.5 Aerial View of Apartment Complex Damage in Wichita Falls, Texas $(\mathrm{F} 4,1979)$

2.6 Timber Planks (Perforate 3 Feet into the Ground in Hubbard, Texas $(\mathrm{F} 2,1973)$

2.7 A 2x4 Timber Plank Slices Between Ceiling Channel and Window Frame in Bossier City, Louisiana (F5, 1978)

2.8 Timber Planks Penetrates Mansard roof in Wichita Falls, Texas (F4, 1979) 22

2.9 Timber Planks Penetrate Residential Roof in Cheyenne, Wyoming $(\mathrm{F} 4,1979)$

2.10 A 2x6 Timber Plank Slices Through Unreinforced Concrete Block Wall at Altus, AFB, Oklahoma, (F3, 1982)

2.11 Various Debris Found in the Altus, Oklahoma, AFB Tornado (F3, 1982) 24

2.12 A Piece of $1 / 2$-in. Thick Plywood Slices Through Rear Fender of Automobile in Altus, Oklahoma AFB (F3, 1982)

2.13 Various Pieces of Debris Have Collected Against school Bus in Bossier City, Louisiana (F5, 1978)

2.14 Steel Light Pole Was Ripped from Its Foundation in Omaha, Nebraska (F4, 1975) 
2.15 Anchor Bolts of This Light Pole Have Sheared off in Omaha, Nebraska (F4, 1975)

2.16 A 2-in. dia. Pipe Penetrated Residential Wall in Plainview, Texas (F3, 1973)

2.17 This 3-in. dia. Steel Pipe (Approximately 75 Pounds) was Transported By the Sweetwater, Texas Tornado (F3, 1986)

2.18 A 2-in. Dia. Electrical Conduit Penetrated the Ground in Hubbard, Texas (F2, 1978)

2.19 A Van Rolled in the Omaha, Nebraska, F4 Tornado

2.20 An Automobile That Was Slammed Against a Steel Pole in Bossier City, Louisiana (F5, 1978)

2.21 Steel Wide-Flange Beam Transported 450 Feet from its Original Location in Bossier City, Louisiana (F5, 1978)

2.22 A Bond Beam was Lifted From the Top of a Concrete Block Wall in Altus, Oklahoma, AFB Tornado (F4, 1982)

2.23 Aerial View of Hubbard, Texas, Tornado (F2, 1973)

2.24 Aerial View of Sweetwater, Texas, Tornado (F2, 1973)

2.25 Aerial View of Wichita Falls, Texas (F4, 1979)

2.26 Loose Objects on Ground, Grand Gulf, Mississippi (F3, 1978) 39

3.1 Spatial Relationship Between Tornado and Missile $\quad 61$

3.2 Calculated Missile Trajectories and Observed Impact Points 65

3.3 Missile Position Relative to Tornado Position When Missile Is Released on Left Side of Tornado Path

3.4 Missile Position Relative to Tornado Position When Missile Is Released on Right Side of Tornado Path

3.5 Variation of Wind Speed Across Tornado Path

3.6 Horizontal and Vertical Speeds Versus Time and Height Versus Time for Timber Missile 
3.7 Typical Trajectories of Timber Missiles Located at Various Distances from F3 Tornado Path Centerline

3.8 Horizontal and Vertical Missile Speeds and Height Versus Time for 3-in dia. Steel Missile

3.9 Typical Trajectories of 3-in. dia. Steel Pipe Missiles from F5 Tornado 85

$\begin{array}{lll}4.1 & \text { Missile Impact Nomenclature } & 90\end{array}$

4.2 Comparison of Rotz and Modified NDRC Equations 101

4.3 Plan View of Missile Launching Facility 111

$\begin{array}{lll}4.4 & \text { Elevation View of Missile Launching Facility } & 112\end{array}$

$\begin{array}{lll}4.5 & \text { Missile Launcher } & 113\end{array}$

$\begin{array}{lll}4.6 & \text { Air Tank } & 113\end{array}$

$\begin{array}{lll}4.7 & \text { Ball Valve Assemblies } & 114\end{array}$

$\begin{array}{lll}4.8 & \text { Control Panel } & 115\end{array}$

4.9 Back Side of Reaction Frame 117

4.10 Timing Gates $\quad 118$

$\begin{array}{lll}4.11 & \text { Timers } & 118\end{array}$

$\begin{array}{lll}\text { 4.12 CR-6.1 Data } & 126\end{array}$

$\begin{array}{lll}\text { 4.13a } & \text { Front Face of CR-6.2 } & 127\end{array}$

$\begin{array}{lll}4.13 b & \text { Back Face of CR-6.2 } & 128\end{array}$

$\begin{array}{lll}4.14 & \text { CR-6.2 Data } & 129\end{array}$

4.15a Front Face of CR-6.2 130

4.15b Back Face of CR-6.2 131

$\begin{array}{lll}\text { 4.16 CR-6.3 Data } & 132\end{array}$

$\begin{array}{lll}4.17 \mathrm{a} & \text { Front Face of CR-6.3 } & 133\end{array}$ 
4.17b Back Face of CR-6.3 134

$\begin{array}{lll}4.18 & \text { CR-8.1 Data } & 136\end{array}$

4.19b Front Face of CR-8.1 137

$\begin{array}{lll}4.19 b & \text { Back Face of CR-8.1 } & 138\end{array}$

4.20 CR-8.2 Data $\quad 139$

4.21a Front Face of CR-8.2 140

4.21b Back Face of CR-8.2 141

4.22 CR-8.3 Data 142

4.23a Font Face of CR-8.3 143

4.23b Back Face of CR-8.3 144

4.24 CR-9.1 Data 146

$\begin{array}{lll}4.25 & \text { CR-9.2 Data } & 147\end{array}$

$\begin{array}{lll}4.26 \mathrm{a} & \text { Front Face of CR-9.2 } & 148\end{array}$

4.26b Back Face of CR-9.2 149

$\begin{array}{lll}\text { 4.27 CR-10.1 Data } & 150\end{array}$

4.28a Front Face of CR-10.1 151

4.28b Back Face of CR-10.1 152

$\begin{array}{lll}4.29 & \text { CMU-8.1 Data } & 156\end{array}$

4.30a Front Face of CMU-8.1 157

4.30b Back Face of CMU-8.1 158

$\begin{array}{lll}4.31 & \text { CMU-12.2 Data } & 159\end{array}$

$\begin{array}{lll}\text { 4.32a } & \text { Front Face of CMU-12.2 } & 160\end{array}$

$\begin{array}{lll}4.33 & \text { CBM-(9.5).1 Data } & 161\end{array}$ 
4.34a Front Face of CBM- (9.5).1

4.34b Back Face of CBM- (9.5). 1

4.35 CBCMU-12.1 Data

4.36a Front Face of CBCMU-12.1 


\section{EXECUTIVE SUMMARY}

High winds tend to pick up and transport various objects and debris, which are referred to as wind-borne missiles or tornado missiles, depending on the type of storm. Missiles cause damage by perforating the building envelope or by collapsing structural elements such as walls, columns or frames. The primary objectives of this study are as follows:

1. to provide a basis for wind-borne or tornado missile criteria for the design and evaluation of DOE facilities, and

2. to provide guidelines for the design and evaluation of impact-resistant missile barriers for DOE facilities

The first objective is accomplished through a synthesis of information from windstorm damage documentation experience and computer simulation of missile trajectories. The second objective is accomplished by reviewing the literature, which describes various missile impact tests, and by conducting a series of impact tests at a Texas Tech University facility to fill in missing information.

Damage documentation files at Texas Tech University (TTU) contain data collected from more than 70 windstorm events over the last 25 years. Tornadoes tend to pick up and transport missiles more readily than other windstorms because of their high wind speeds and unique vertical wind speed component. Tornado missiles are addressed, and then criteria for missiles appropriate to other storms are inferred.

The DOE design criterion (DOE -STD- 1020-94) includes tornado wind speeds up to and including Fujita Scale Category F4. Tornadoes rated F2, F3 and F4 that had documented missile data were identified in the TTU damage documentation. The 
missiles were classified into three categories: Lightweight missiles that are lifted and transported by the winds, medium-weight missiles that are accelerated horizontally as they fall to the ground, from some height above ground and large heavy missiles that roll and tumble along the ground. These classes of missiles are represented by a $2 \times 4$ timber (15 lb), a 3-in. dia. steel pipe (75 lb) and an automobile (3000 lb), respectively.

The TTU tornado missile trajectory simulation software was used to estimate the speed, maximum height, and distance traveled by the missiles. The details of the trajectory simulation program are presented in this report along with supporting data for validation. The recommended missile impact speeds in DOE STD 1020-94 were deduced from the trajectory calculations (see Table 1.1 for missile impact criteria).

The literature was reviewed to identify missile impact tests that have been conducted in the past. Most tests conducted prior to about 1985 involved the missile spectrum specified by the US Nuclear Regulatory Commission for design of nuclear power plant facilities. The missiles and impact speeds were very much larger than those in the DOE criteria. Tests were conducted at TTU to fill in information missing from the literature. Tests were conducted to define threshold impact speeds for perforation and backface scabbing. Wall configurations to meet the defined impact criteria were then built and tested. Recommended wall sections are presented that will meet the impact criteria in DOE 1020-94 (see Section 4.7). These include walls constructed of reinforced concrete, clay brick and concrete masonry. 



\section{INTRODUCTION}

\subsection{Wind and Tornado Missiles}

High winds tend to pick up and transport various objects and debris, which are referred to as wind-borne missiles, or simply tornado missiles. Tornado missiles tend to be larger, achieve higher velocities, and travel greater distances than missiles generated by hurricanes and other extreme winds. Wind-borne missiles present a major threat of injury or death to persons caught in the open during a storm. In addition, missiles cause physical damage to buildings and facilities.

In non-tornadic winds (thunderstorm outflows, downslope winds, and hurricanes), there is no significant vertical component to the wind velocity. Objects propelled horizontally by the wind may experience some uplift, but generally are falling under the influence of gravity. Gravity forces are partially overcome by the upward wind velocity component in tornadic winds. Lightweight missiles such as sheet metal or pieces of wood sometimes are carried to great heights before finally falling to the ground.

Wind-borne missiles range in size from roof gravel to large objects such as railroad cars or storage tanks. Bailey (1984) categorized missiles as small, medium or heavy. The small missile category includes roof gravel, tree branches and pieces of lumber. Small diameter pipes, steel roof joists and small beams comprise typical missiles in the medium category. Utility poles, large diameter pipes, automobiles, railroad cars, and storage tanks fit into the heavyweight missile class. The heavyweight missiles are found only in damage of very intense tornadoes. The types of missiles depend on the damage caused by the windstorm. Damage to residences produce numerous timber 
missiles, while damage to commercial or industrial facilities tends to produce heavier and more rigid missiles. Construction sites provide a prime source of both medium and heavy missiles.

\subsection{Objectives and Scope of Study}

Wind-borne missiles are a potential damage mechanism in windstorms.

Protection against wind-borne missiles should be a component of all wind-resistant designs. This report is the culmination of years of study of the effects of wind-borne missiles. The findings and recommendations are based on observations of missiles in post-storm damage investigations, computer simulations of missile trajectories, and tests of the impact resistance of various construction materials. Although the study is primarily directed to the design and evaluation of Department of Energy (DOE) facilities, much of the information is applicable to other wind-resistant buildings and structures.

In the DOE context, a facility can be divided into structures, systems, or components (SSCs) according to DOE-STD-1021-93 (DOE 1993). A Structure is an element, or collection of elements, that provides support or enclosure such as a building, freestanding tank, basin, or stack. A system is a collection of components assembled to perform a function, such as piping, cable trays, conduits, or HVAC installations. A component is an item of equipment, such as a pump, valve or relay, or an element of a larger array, such as a length of pipe, elbow, or reducer. Unlike earthquakes, wind forces in general only affect structures. However, wind-borne missiles are capable of damaging structures, systems, and components. 
The objectives of this study are as follows:

1. to provide a basis for wind-borne missile criteria used in the design and evaluation of SSCs in DOE facilities, and

2. to provide guidelines for design and evaluation of impact-resistant missile barriers for SSCs in DOE facilities.

The first objective is accomplished through synthesis of information from windstorm damage documentation experience and computer simulation of missile trajectories. Data files of more than 70 windstorm events documented by personnel at Texas Tech University were consulted in the course of this study. Damage documentation alone does not give the complete story of missile behavior. One can observe the original location and impact point of a missile, but the maximum velocity and maximum height attained by the missiles are unknown. Occasionally, a movie film or video of a tornado in action will show trajectories of missiles, but these events are rare. Computer simulation is about the only tool available to predict the trajectories of postulated tornado missiles. Although computer simulations of missile trajectories cannot tell the exact story, they indicate general trends in the behavior of missiles that are adequate for design purposes. Indications of missile velocity, height above ground, and distance traveled can be obtained from a missile trajectory simulation model.

The second objective of the study is accomplished by reviewing literature which describes various missile impact tests and by conducting impact tests at Texas Tech University to fill in missing information. This report describes the Texas Tech University tests. 


\subsection{DOE Approach to Natural Phenomena Hazards}

DOE Order 5480.28 establishes DOE policies and requirements for natural phenomena hazard (NPH) mitigation for DOE sites and facilities using a graded approach. The graded approach is one in which SSCs are placed into performance categories such that the required level of analysis, documentation, and actions are commensurate with following factors:

1. the relative importance to safety, safeguards, the environment and security,

2. the expected magnitude of any hazard involved,

3. the programmatic mission of a facility,

4. the particular characteristics of the SSCs, and

5. the cost and replaceability of the SSCs.

SSCs comprising a DOE facility are assigned to appropriate performance categories utilizing the approach described in DOE (1993). The design and evaluation criteria for natural phenomena hazards are specified in DOE STD 1020-94 (DOE 1994). A Natural Phenomena Hazard panel developed the design and evaluation approach, which is consistent with DOE Order 5480.28. Components of the design and evaluation approach include:

1. Natural Phenomena Hazard Probability (NPH) assessment from which loads are derived,

2. Design and evaluation procedures for each performance category with which to evaluate SSC response to the NPH loads, and

3. Standards to assess whether or not the computed response is acceptable. 
Natural Phenomena Hazards Addressed in DOE STD 1020-94 includes

earthquakes, winds, tornadoes and floods. Missiles are a part of the wind and tornado criteria.

Wind hazard models for 25 DOE sites have been published (Coats and Murray, 1985). A wind hazard exceedance model gives probability versus wind speed for a particular site. The model addresses those windstorms that are likely to affect the site, which may include straight winds, hurricanes, or tornadoes. A uniform treatment of wind loads generally follows the procedures of ASCE 7-88 (ASCE 1990).

The DOE STD 1020-94 establishes the level of wind hazard probability for each of the four performance categories, which in turn, establishes the appropriate wind speed for design and evaluation of SSCs. Missile criteria consistent with the design and evaluation wind speeds also are specified in the DOE STD 1020-94. The material presented herein provides a rationale for the wind-borne missile criteria specified in DOE STD 1020-94.

Table 1.1 summarizes the wind-borne missile criteria for design and evaluation of DOE SSCs. Performance Categories 1 and 2 consider only the effects of straight winds and hurricanes, whereas Performance Categories 3 and 4 also consider tornadoes, if they are deemed a viable threat at the site. Wind-borne missile criteria are specified for Performance in Categories 3 and 4 for straight winds, hurricanes or tornadoes, depending on which storms are applicable at a particular site. 
Table 1.1 Summary of Minimum Wind Design Criteria for DOE SSCs

(from DOE STD 1020-94)

\begin{tabular}{|c|c|c|c|c|c|}
\hline & $\begin{array}{c}\text { Performance } \\
\text { Category }\end{array}$ & [1] & [2] & [3] & [4] \\
\hline 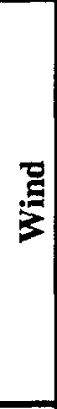 & $\begin{array}{c}\text { Hazard } \\
\begin{array}{c}\text { Annual Probability } \\
\text { of Exceedance }\end{array} \\
\text { Importance Factor * } \\
\text { Missile Criteria }\end{array}$ & $\begin{array}{l}1.00 \\
\text { NA }\end{array}$ & $\begin{array}{l}1.07 \\
\text { NA }\end{array}$ & $\begin{array}{c}1 \times 10^{-3} \\
1.00 \\
2 " \times 4 " \text { timber plank } \\
15 \mathrm{Ib} @ \\
50 \text { mph (horiz.); } \\
\text { max. height } 30 \mathrm{ft} .\end{array}$ & $\begin{array}{c}1.00 \\
\text { 2"x4" timber plank } \\
15 \mathrm{lb} @ \\
50 \text { mph (horiz.); } \\
\text { max. height } 50 \mathrm{ft} .\end{array}$ \\
\hline 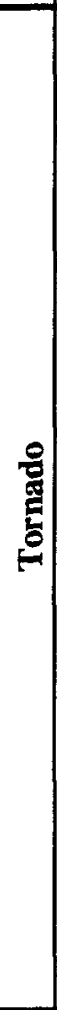 & $\begin{array}{c}\text { Hazard } \\
\begin{array}{c}\text { Annual Probability } \\
\text { of Exceedance }\end{array} \\
\text { Importance Factor * } \\
\text { APC } \\
\text { Missile Criteria }\end{array}$ & $\begin{array}{l}\text { NA } \\
\text { NA } \\
\text { NA } \\
\text { NA }\end{array}$ & $\begin{array}{l}\text { NA } \\
\text { NA } \\
\text { NA } \\
\text { NA }\end{array}$ & $\begin{array}{c}2 \times 10^{-5} \\
1.00 \\
40 \text { Psf @ } \\
20 \text { Psf/sec } \\
\\
2 \text { "x4" timber plank } \\
15 \mathrm{Ib} @ \\
100 \text { mph (horiz.); } \\
\text { max. height } 150 \\
\text { ft.; } 70 \text { mph (vert.) } \\
\\
3 \text { in. dia. Std. Steel } \\
\text { Pipe } 75 \text { lb @ } \\
50 \text { mph (horiz.); } \\
\text { max. height } 75 \mathrm{ft} . \\
35 \text { mph (vert.) }\end{array}$ & $\begin{array}{c}1.00 \\
125 \text { Psf @ } \\
50 \text { Psf/sec } \\
\\
\text { 2"x4" timber plank } \\
15 \mathrm{lb} @ \\
150 \text { mph (horiz.); } \\
\text { max. height } 200 \\
\text { ft.; } 100 \text { mph (vert.) } \\
3 \text { in. dia. Std. Steel } \\
\text { Pipe } 75 \text { Ib @ } \\
75 \text { mph (horiz.); } \\
\text { max. height } 100 \mathrm{ft} . \\
50 \text { mph (vert.) } \\
3000 \mathrm{Ib} \\
\text { automobile @ } 25 \\
\text { mph, rolls and } \\
\text { tumbles }\end{array}$ \\
\hline
\end{tabular}




\subsection{Background}

Appropriate levels of hazard probabilities for DOE SSCs are derived from precedents established by governmental agencies or by established industrial practices.

For hazardous facilities, the practices have evolved from those adopted for nuclear power plant design.

The general design criteria for nuclear power plants are established in Title 10,

CFR, Part 50, Appendix A. General Criterion 2 states:

Structures, systems and components important to safety shall be designed to withstand the effects of natural phenomena such as earthquake, tornadoes, hurricanes, flood, tsunami and seiches without loss of capability to perform their safety function. The design basis shall reflect the following:

1. Appropriate considerations of the most severe natural phenomena that have been historically reported for the site and surrounding area with sufficient margin for limited accuracy, quantity and the period of time in which the historical data have been accumulated,

2. Appropriate combinations of the effect of normal and accidental conditions of the effects of natural phenomena, and

3. The importance of the safety function to be performed.

Ravindra et al. (1993) traces the evolution of tornado design practice for nuclear power plants. In order to meet the Title $10 \mathrm{CFR}$ criteria, the Atomic Energy Commission (AEC) established criteria based on an annual tornado hazard probability of $1 \times 10^{-7}$ per year. The rationale for the $10^{-7}$ value has been lost over the years. Old records suggest it was predicated on the assumption of 2000 operating nuclear power plants in the U. S. by the year 2000 A.D., an assumption which has not been realized.

A study referred to as WASH 1300 was performed by Markee, et al. (1974) to establish the tornado hazard on a probabilistic basis at the $1 \times 10^{-7}$ probability level. The study incorporated several layers of conservatism. Nevertheless, WASH-1300 became 
the basis for Reg. Guide 1.76 (USNRC 1974), which forms the design basis for protection of nuclear power plants against tornadoes (see Table 1.2).

Reg. Guide 1.76 does not specify tornado missile criteria. Standard Review Plan (SRP) 3.5.1.4 (USNRC 1975) provides acceptance criteria for identification of appropriate design missiles and their impact speeds for nuclear power plants. The acceptance criteria were established after a number of topical studies on tornado missiles were submitted by various $\mathrm{A} / \mathrm{E}$ firms engaged in nuclear power plant design. The missile impact speeds are expressed as a function of the design basis for tornado wind speed.

Table 1.3 lists the missiles that were acceptable in June 1975. Later, in 1977, the Nuclear Regulatory Commission (agency that replaced the old AEC) adopted alternative missile criteria consisting of two sets of design missiles denoted Spectrum I and Spectrum II. Spectrum I missiles consisted of a rigid slug and a $2 \times 4$ timber plank. Spectrum II consisted of another list of planks, pipes, poles, and automobiles. A minimum acceptable barrier thickness for damage protection against tornado-generated missiles is listed in SRP Section 3.5.3.

The damage to a nuclear power plant by tornado missiles is a very low probability event because a sequence of events must take place in order for a missile to cause an unacceptable accident. Probabilistic risk assessment (PRA) studies for extreme winds have been published for the Indian Point, Limerick, Millstone, Seabrook and Zion nuclear plants. In addition, extreme wind studies have been conducted for six plants as part of the TAP A-45 abbreviated PRA project. Results of the full-blown PRAs are summarized in Table 1.4. 
Table 1.2 Tornado Design Criteria for Nuclear Power Plants

(Reg. Guide 1.76 (AEC 1974))

\begin{tabular}{|c|c|c|c|c|c|c|c|}
\hline \multirow[t]{2}{*}{ Region } & \multirow{2}{*}{$\begin{array}{l}\text { Maximum } \\
\text { Wind } \\
\text { Speed a } \\
\text { (mph) }\end{array}$} & \multirow{2}{*}{$\begin{array}{l}\text { Rotational } \\
\text { Wind } \\
\text { Speed } \\
\text { (mph) }\end{array}$} & \multicolumn{2}{|c|}{$\begin{array}{c}\text { Translational } \\
\text { Wind Speed } \\
\text { (mph) }\end{array}$} & \multirow{2}{*}{$\begin{array}{c}\text { Radius of } \\
\text { Maximum } \\
\text { Rotational } \\
\text { Wind Speed } \\
\text { (ft.) }\end{array}$} & \multirow{2}{*}{$\begin{array}{c}\text { Pressure } \\
\text { Drop } \\
\text { (psi) }\end{array}$} & \multirow{2}{*}{$\begin{array}{c}\text { Rate of } \\
\text { Pressure } \\
\text { Drop } \\
\text { (psi/sec) }\end{array}$} \\
\hline & & & Maximum & Minimum & & & \\
\hline I & 360 & 290 & 70 & 5 & 150 & 3.0 & 2.0 \\
\hline II & 300 & 240 & 60 & 5 & 150 & 2.25 & 1.2 \\
\hline III & 240 & 190 & 50 & 5 & 150 & 1.5 & 0.6 \\
\hline
\end{tabular}

The maximum wind speed is the sum of the rotational speed component and the maximum translational speed component

Tornado Intensity Regions

Table 1.3 Tornado Missile Criteria for Nuclear Power Plants (NRC 1975)

\begin{tabular}{|l|c|c|ccc|}
\hline \multicolumn{1}{|c|}{ Missile } & $\begin{array}{c}\text { Weight } \\
\text { (Ibs) }\end{array}$ & $\begin{array}{c}\text { Nominal } \\
\text { Dimensions } \\
\text { (in.) }\end{array}$ & \multicolumn{3}{|c|}{$\begin{array}{c}\text { Missile Velocity } \\
\text { (mph) }\end{array}$} \\
\cline { 4 - 6 } & 115 & $4 \times 12 \times 144$ & 288 & II & III \\
A. Wood Plank & 78 & 3-in. dia x 120 & 144 & 120 & 96 \\
C. 1-in. dia. Steel Rod & 9 & 1-in. dia x 36 & 216 & 180 & 144 \\
D. 6-in. dia. Sch 40 Pipe & 285 & 6-in. dia x 180 & 144 & 120 & 96 \\
E. 12-in. dia. Sch 40 Pipe & 750 & 12 -in. dia x 180 & 144 & 120 & 96 \\
F. Utility Pole & 1125 & 13.5 -in. dia x 420 & 144 & 120 & 96 \\
G. Automobile & 4000 & $196 \times 80 \times 50$ & 72 & 60 & 48 \\
\hline
\end{tabular}

Missiles A-E are considered at all elevations;

Missiles F-G are considered up to $30 \mathrm{ft}$. above ground 
The extreme wind studies for the TAP A-45 project were not full-scope PRAs, but the analysis procedure was similar. Plants included in the study were Arkansas NuclearOne, Cooper, Point Beach, Quad Cities, St. Lucie and Turkey Point. In all six cases studied, the estimated core damage frequency was below $1 \times 10^{-8}$ per year when tornado missiles were part of the damage sequence.

The point of this discussion on NRC tornado missile criteria for nuclear power plants is that the regulatory authority adopted a very conservative approach back in the late 1960s and has not substantially reduced it in the last 25 years. The missile criteria adopted in DOE STD 1020-94 for design and evaluation of DOE SSCs are significantly different from the NRC criteria for nuclear power plants. The DOE criteria are different because:

1. missiles are selected from actual field observations,

2. level of risk is different from nuclear power plants and

3. design tornado wind speeds are significantly lower than those in NRC criteria.

In the next section, field observations of missiles are reviewed in order to validate the tornado missile specified in DOE design and the evaluation criteria for SSCs. Section 3 describes the methodology and results of tornado missile trajectory simulation. This information is used to set missile impact speeds and maximum height above ground. Section 4 describes impact tests and recommends appropriate barriers to resist the specified missile impact criteria. 


\section{Table 1.4 Summary of Results of Probabilistic Risk Assessments for Selected Nuclear Power Plants}

\section{(Tornado Missile)}

\begin{tabular}{|c|l|}
\hline Plant & \multicolumn{1}{|c|}{ Results } \\
\hline Indian Point & $\begin{array}{l}\text { Core damage frequently due to tornado missile for each of two units was estimated to be less than } \\
1 \times 10^{-7} \text { per year } \\
\text { Systems analysis were performed and it was found that the contribution of tornado-initiated } \\
\text { accidents to core damage frequency is less than } 1 \times 10^{-9} \text { per year, including missile-caused accidents } \\
\text { Millstone Unit 3 } 3 \text { Using the results from Twisdale }(1981), \text { the frequency of tornado missile-induced core melt accident } \\
\text { sequence was estimated at less than } 1 \times 10^{-7} \text { per year }\end{array}$ \\
Zion & $\begin{array}{l}\text { Core damage frequency due to tornado missiles was estimated at 3.4x } 10^{-10} \text { per year } \\
\text { Based on results of tornado risk analysis repurted in Twisdale (1981), the probability of tornado } \\
\text { missiles striking and scabbing the walls of the Zion plant structure was estimated at } 2 \times 10^{-6} \text { per year. } \\
\text { The probability of damaging certain equipment, thereby leading to core damage was estimated to be } \\
\text { around } 12 \times 10^{-8} \text { per year. The core damage probability was judged to be acceptably small; tornadoes } \\
\text { and tornado missiles were not considered to be significant risk contributors. }\end{array}$ \\
\hline
\end{tabular}




\section{MISSILE CLASSES BASED ON FIELD OBSERVATIONS}

The best available information on the kinds of missiles picked up and transported by extreme windstorms comes from field observations of windstorm damage. The damage documentation files at Texas Tech University contain data collected from more than 70 windstorm events over the last 25 years. Although most of the studies did not have missile documentation as a primary objective, significant amounts of data relating to missiles were collected.

Tornadoes tend to pick up and transport missiles more readily than other windstorms because the wind speeds are higher and tornadoes have a strong vertical wind component in the vortex. The behaviors of tornado missiles are treated first because more information is available. The behavior of missiles in non-tornadic storms is deduced from the results of the tornado missile studies.

The objective of this study is to determine the most probable missiles found in tornado damage paths as a function of tornado intensity. The Fujita Scale is used to rate tornado intensity. The identified missiles are then used in trajectory calculations as described in Chapter 3 of this report to determine missile speed, maximum height and distance traveled. These studies provide the data necessary to establish tornado missile impact criteria for the design and evaluation of DOE facilities (SSCs).

The amount of information on missiles that can be obtained from the field is limited. The impact point is known. Sometimes it is possible to determine the point of origin of the missile, but nothing is known about the trajectory the missile followed as it was transported by the winds. The size and weight of a missile can be measured in the field, but very little information of this type is available. The material and size of 
missiles can be estimated from good quality, low-level aerial photos of the damage path. The Missile material is identified; the weight is then estimated by assuming a unit weight for the material. An approximate scale of aerial photo is determined from objects of known size. This procedure is not precise, but it gives general characteristics of the missiles found in tornado damage paths.

\subsection{Approach}

The following approach is taken in this study:

1. Express the design tornado wind speeds for each DOE site in terms of the Fujita-Scale categories.

2. Identify those tornadoes from the Texas Tech University Damage files that contain missile data and determine their Fujita-Scale rating.

3. Identify the sources and types of missiles visible in aerial photos and estimate mean size and weight.

4. Count the number of individual missiles visible in aerial photos and estimate mean size and weight.

5. Determine a statistical distribution of missiles counted in Step (4)

6. Group missiles into various classes.

7. Identify a representative missile for each class.

\section{$2.2 \quad$ Fujita Scale}

Because it is impossible to obtain direct anemometer measurements of wind speeds in a tornado, indirect methods are relied upon to estimate tornado wind speeds. Several methods have been successfully used, including evaluation of structural damage, photogrammatic analysis of tornado movies, and analysis of cycloidal ground marks. 
The most widely accepted method is the Fujita-Scale. Wind speeds are estimated from the appearance of damage. A Fujita Scale category is assigned to the tornado based on the worst damage observed in the path. Each category is related to range of wind speed. Table 2.1 describes the damage associated with each Fujita Scale category.

Table 2.1 Fujita- Scale Classification of Tornadoes (Fujita 1971)

\begin{tabular}{|c|c|c|}
\hline F-Scale & $\begin{array}{l}\text { Wind } \\
\text { Speed* } \\
\text { (mph) }\end{array}$ & Damage Description \\
\hline $\begin{array}{c}\text { (F0) } \\
\text { Light } \\
\text { Damage }\end{array}$ & $40-72$ & $\begin{array}{l}\text { Some Damage to chimneys or TV antennae; breaks branches off trees; pushes } \\
\text { over shallow-rooted trees; old trees with hollow insides break of fall; sign } \\
\text { boards damaged. }\end{array}$ \\
\hline $\begin{array}{c}\text { (F1) } \\
\text { Moderate } \\
\text { Damage }\end{array}$ & $73-112$ & $\begin{array}{l}\text { Peel surface off roofs; windows broken; trailer houses pushed or overturned; } \\
\text { trees on soft ground uprooted; some trees snapped; moving autos pushed off the } \\
\text { road. }\end{array}$ \\
\hline $\begin{array}{l}\text { (F2) } \\
\text { Considerable } \\
\text { Damage }\end{array}$ & $113-157$ & $\begin{array}{l}\text { Roof torn off frame houses leaving strong upright wall standing; weak structure } \\
\text { or outbuildings demolished; trailer houses demolished; railroad boxcars pushed } \\
\text { over; large trees snapped or uprooted; light object missiles generated; cars blow } \\
\text { off highway; block structures and walls badly damaged. }\end{array}$ \\
\hline $\begin{array}{c}\text { (F3) } \\
\text { Severe } \\
\text { Damage }\end{array}$ & $158-206$ & $\begin{array}{l}\text { Roofs and some walls torn off well-constructed frame houses; some rural } \\
\text { buildings completely demolished or flattened; trains overturned; steel framed- } \\
\text { hanger warehouse structures torn; cars lifted off the ground and may roll some } \\
\text { distance; most trees in a forest uprooted, snapped, or leveled; block structures } \\
\text { often leveled. }\end{array}$ \\
\hline $\begin{array}{c}\text { (F4) } \\
\text { Devastating } \\
\text { Damage }\end{array}$ & $207-260$ & $\begin{array}{l}\text { Well-constructed frame houses leveled, leaving piles of debris; structure with } \\
\text { weak foundation lifted, torn, and blown off some distance; trees debarked by } \\
\text { small flying debris; sandy soil eroded and gravel flies in high winds; cars } \\
\text { thrown some distance or rolled considerable distance, finally to disintegrate; } \\
\text { large missiles generated. }\end{array}$ \\
\hline $\begin{array}{c}\text { (F5) } \\
\text { Incredible } \\
\text { Damage }\end{array}$ & $261-318$ & $\begin{array}{l}\text { Strong frame houses lifted clear off foundation and carried some considerable } \\
\text { distance to disintegrate; steel-reinforced concrete structures badly damaged; } \\
\text { automobile-sized missiles carried a distance of } 100 \text { yards or more; trees } \\
\text { debarked completely; incredible phenomena can occur }\end{array}$ \\
\hline
\end{tabular}

*Fujita Scale wind speed is fastest one-quarter mile wind speed at $10 \mathrm{~m}$ in open terrain. 
Table 2.2 lists those DOE sites that have tornado design criteria. The design wind speeds are given (in terms of fastest-one-quarter mile wind speeds) for Performance Categories PC3 and PC4. The corresponding Fujita Scale class is also listed in the table for each site. The design tornado wind speeds range from F1 to F4.

Table 2.2 Tornado Design Wind Speed at DOE Sites

\begin{tabular}{|l|c|c|c|c|}
\hline \multirow{2}{*}{ DOE Site } & \multicolumn{2}{c|}{ PC3 } & \multicolumn{2}{c|}{ PC4 } \\
\cline { 2 - 3 } \cline { 5 - 6 } & Wind Speed & F-Scale & Wind Speed & F-Scale \\
\hline Kansas City, MO & 144 & F3 & 198 & F4 \\
\hline Mound Lab, OH & 136 & F2 & 188 & F4 \\
\hline Pantex, TX & 132 & F2 & 182 & F3 \\
\hline Argonne-East, IL & 146 & F3 & 196 & F4 \\
\hline Brookhaven, NY & 95 & F1 & 145 & F3 \\
\hline Princeton, NJ & 103 & F2 & 150 & F3 \\
\hline FMPL, OH & 139 & F2 & 192 & F4 \\
\hline Oak Ridge, TN & 113 & F2 & 173 & F3 \\
\hline Paducah, KY & 144 & F3 & 198 & F4 \\
\hline Portsmouth, OH & 110 & F2 & 166 & F3 \\
\hline ETEC, CA & 95 & F1 & 111 & F2 \\
\hline Savannah River, SC & 137 & F2 & 192 & F4 \\
\hline
\end{tabular}




\subsection{Tornado Missile Data}

Table 2.3 lists the tornadoes for which missile data are available from the TTU archives along with the Fujita Scale rating of each storm.

Table 2.3

Tornadoes with Documented Missile Data

\begin{tabular}{|l|l|c|}
\hline \multicolumn{1}{|c|}{ Tornado } & Year & Fujita-Scale \\
\hline Burnett, TX & 1973 & F2 \\
Hubbard, TX & 1973 & F2 \\
Monahans, TX & 1977 & F2 \\
Grand Island, NE & 1980 & F2 \\
\hline Plainview, TX & 1972 & F3 \\
Grand Island, NE & 1980 & F3 \\
Kalamazoo, MI & 1980 & F3 \\
Altus AFB, OK & 1982 & F3 \\
Sweetwater, TX & 1986 & F3 \\
West Memphis, AR & 1987 & F3 \\
\hline Louisville, KY & 1974 & F4 \\
McComb, MS & 1975 & F4 \\
Omaha, NE & 1975 & F4 \\
Bossier City, LA & 1978 & F4 \\
Cheyenne, WY & 1979 & F4 \\
Wichita Falls, TX & 1979 & F4 \\
Grand Island, NE & 1980 & F4 \\
Huntsville, AL & 1989 & F4 \\
Plainfield, IL & 1990 & F4 \\
Lancaster, TX & 1994 & F4 \\
\hline Lubbock, TX & 1970 & F5 \\
Xenia, OH & 1974 & F5 \\
Brandenberg, KY & 1974 & F5 \\
Birmingham, AL & 1977 & F5 \\
\hline
\end{tabular}




\subsection{Missile Observations}

\subsubsection{General Views of Damage}

Figure 2.1 shows an aerial view of tornado damage caused by the Wichita Falls, Texas, tornado (F4). The source of missiles in this case was damaged or destroyed residential roofs. The vast majority of pieces are $2 \times 4$ and $2 \times 6$ rafters, joists, or prefabricated truss chords.

Figure 2.2, also from Wichita Falls, shows missiles and debris from the destruction of a shopping mall a half block away. Steel roof joists, steel angles, timber planks, a broken utility pole and sheet metal can be seen in the photo. Figure 2.3 shows an inside courtyard of McNeil Junior High School in Wichita Falls. Light-weight steel channels, angles, chunks of lightweight roofing material, insulation board and tree limbs can be seen in the photo.

Figure 2.4 is a view of a heavily damaged commercial building in Bossier City, Louisiana (F4). One can see pieces of the poured in place light weight gypsum roofing, pieces of metal roof deck, plastic pipe (round white objects), pieces of plywood, and steel angle shapes.

Figure 2.5 is an aerial view of damage from the Wichita Falls, Texas, tornado of 1979 (F4). The source of the missiles is destruction of a large apartment complex. Roofing material and plywood deck have been removed, leaving the prefabricated trusses unsupported on their top chords. The trusses tend to fall over like dominos when this happens. Some trusses have broken into pieces, providing timber plank missiles. 


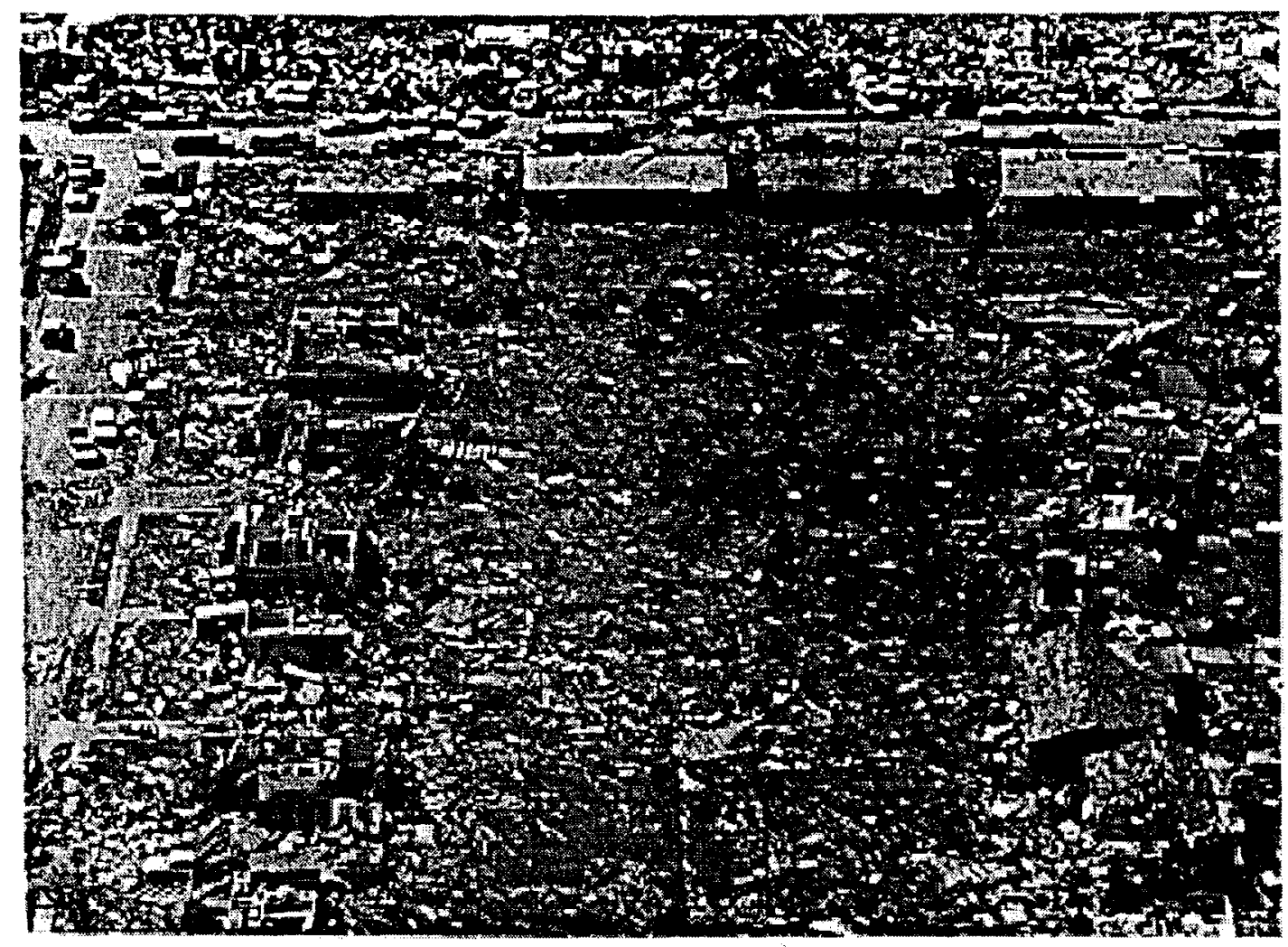

FIGURE 2.1 AERIAL VIEW OF DAMAGE CAUSED BY WICHITA FALLS TORNADO $(\mathrm{F4}, 1979)$

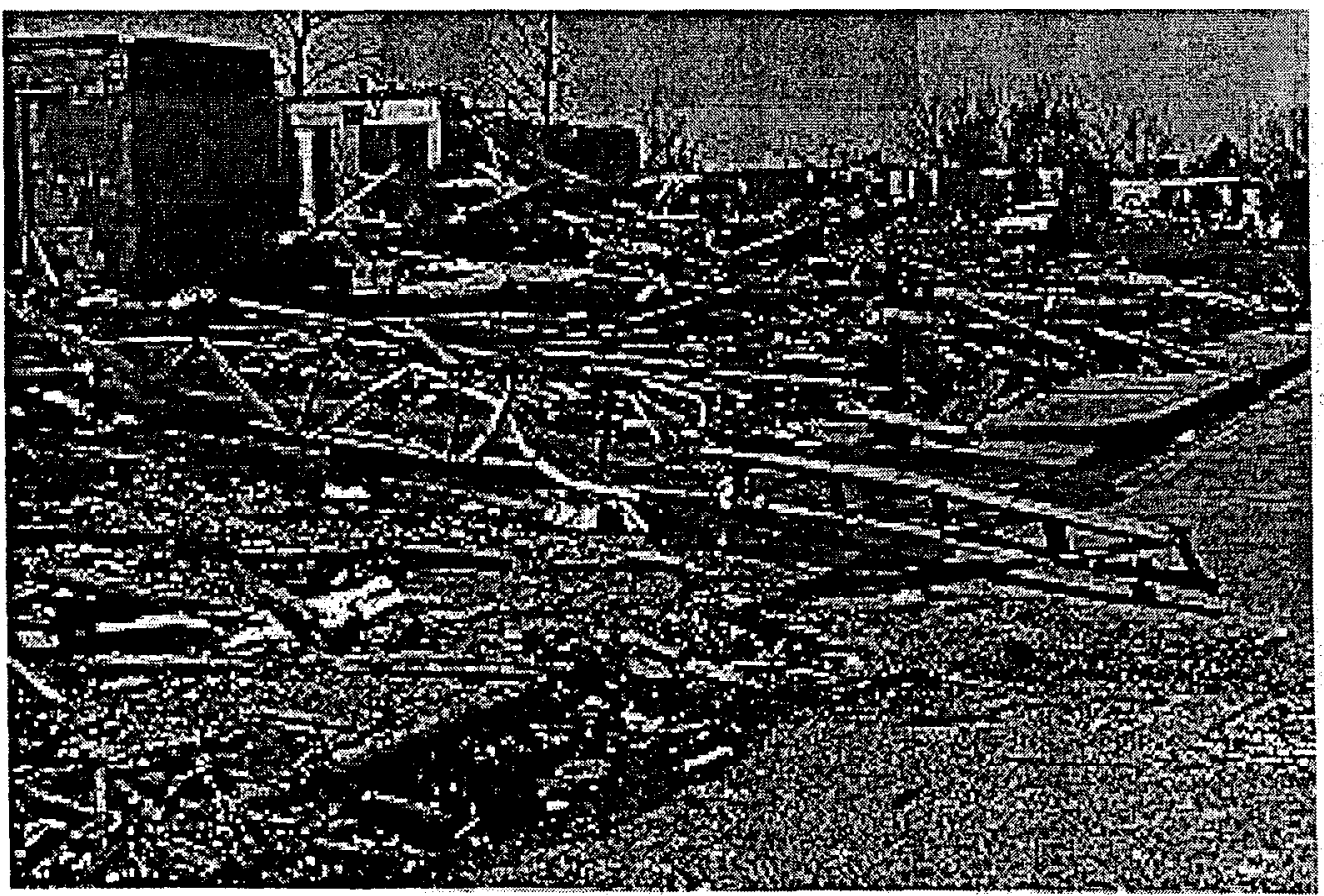

FIGURE 2.2 MISSILES AND DEBRIS FROM DAMAGED SHOPPING

CENTER CAUSED BY WICHITA FALLS, TEXAS TORNADO $(\mathbf{F 4}, \mathbf{1 9 7 9 )}$ 


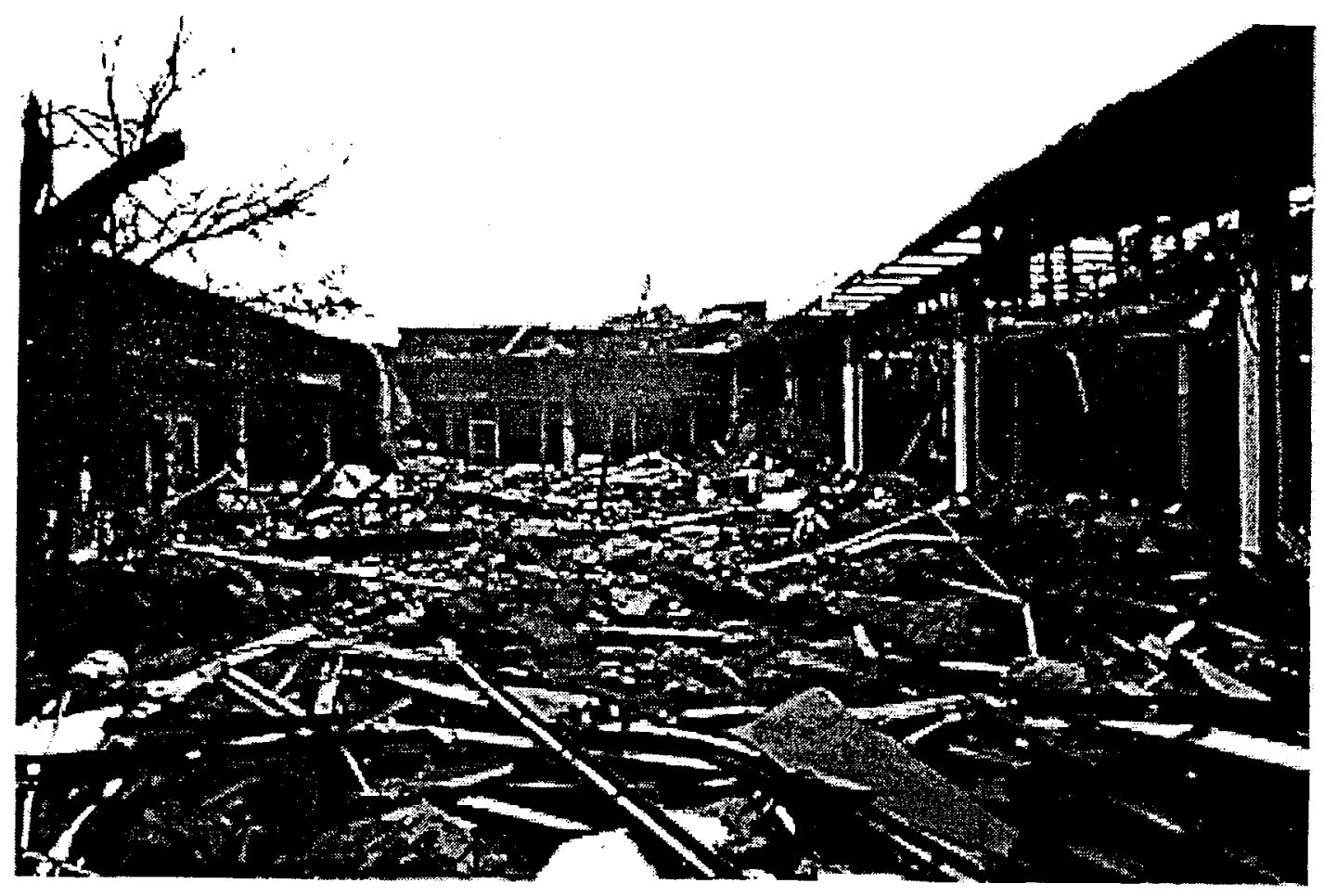

FIGURE 2.3 COURTYARD at MCNEILL JUNIOR HIGH, WICHITA FALLS, TEXAS (F4, 1979)

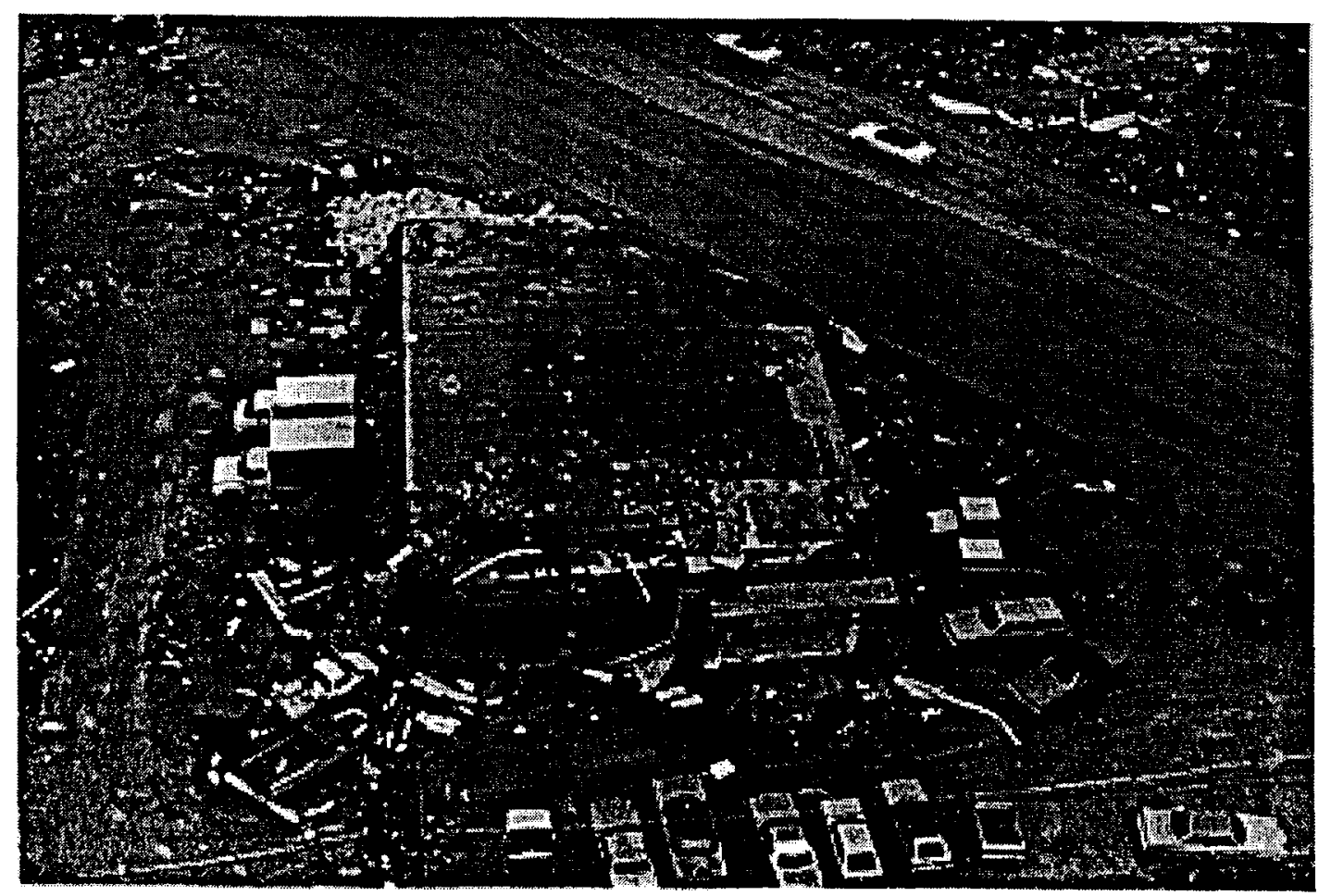

FIGURE 2.4 HEAVILY DAMAGED COMMERCIAL BUILDING IN BOISSIER CITY, LOUISIANA (F4, 1978) 


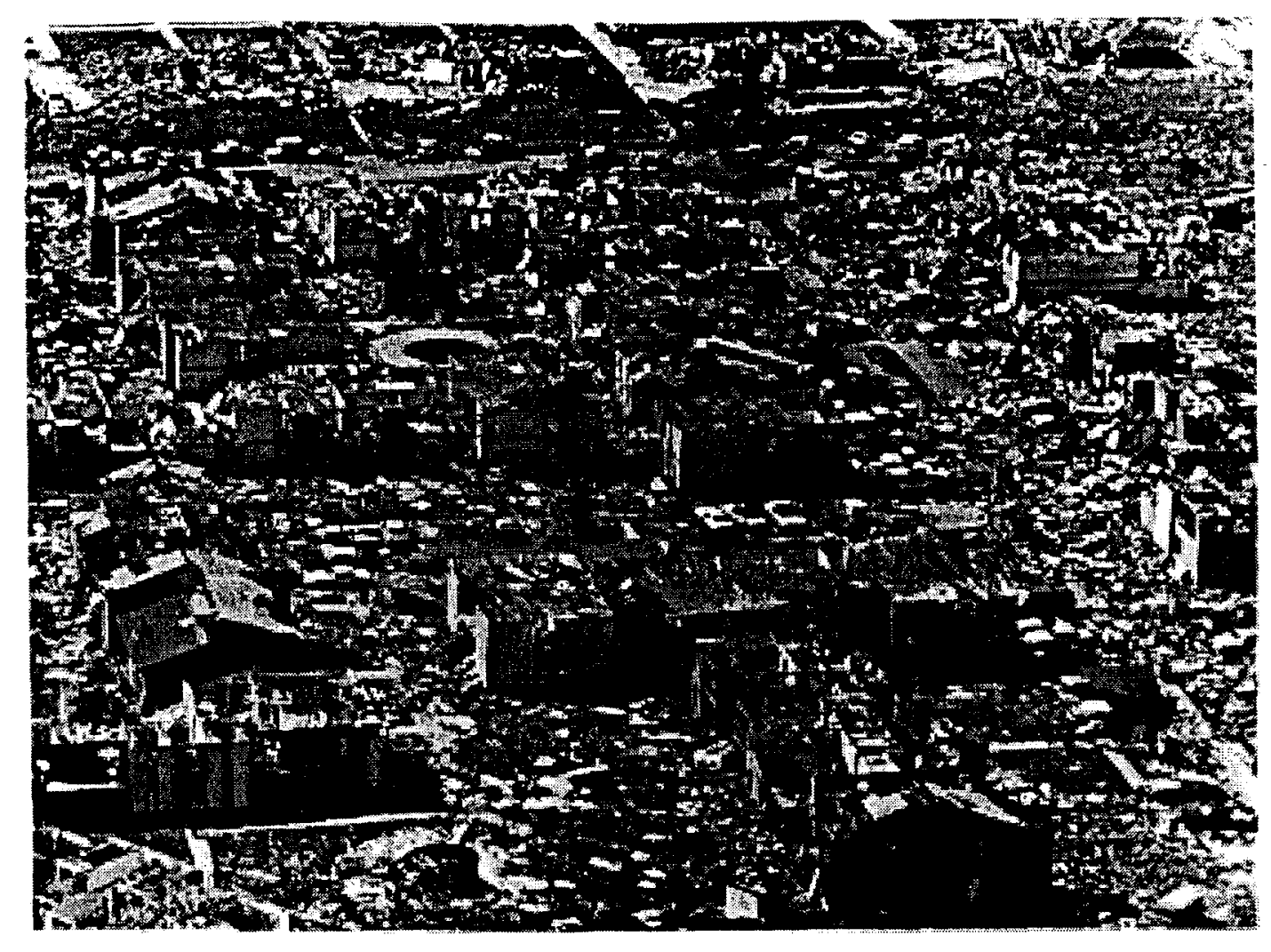

FIGURE 2.5 AERIAL VIEW OF APARTMENT COMPLEX DAMAGE IN WICHITA FALLS, TEXAS (F4, 1979)

\subsubsection{Examples of Individual Missiles}

A number of examples of individual missiles are shown to give a sense of the types that are picked up and transported.

\section{Wood Planks}

Wood planks are the most common missiles found in residential damage. Figure 2.6 in Hubbard, Texas (F2); $2 \times 4$ wood planks perforated 36 in. into the ground. Figure 2.7 in Bossier City, Louisiana (F4); a 2x4 wood plank extended between the ceiling channel and the window frame. The roof may have been lifted slightly during the storm to allow the missile to slip between the two window components. Figure 2.8 in Wichita Falls, Texas (F4); a timber plank penetrated a mansard roof. Figure 2.9 in Cheyenne, 


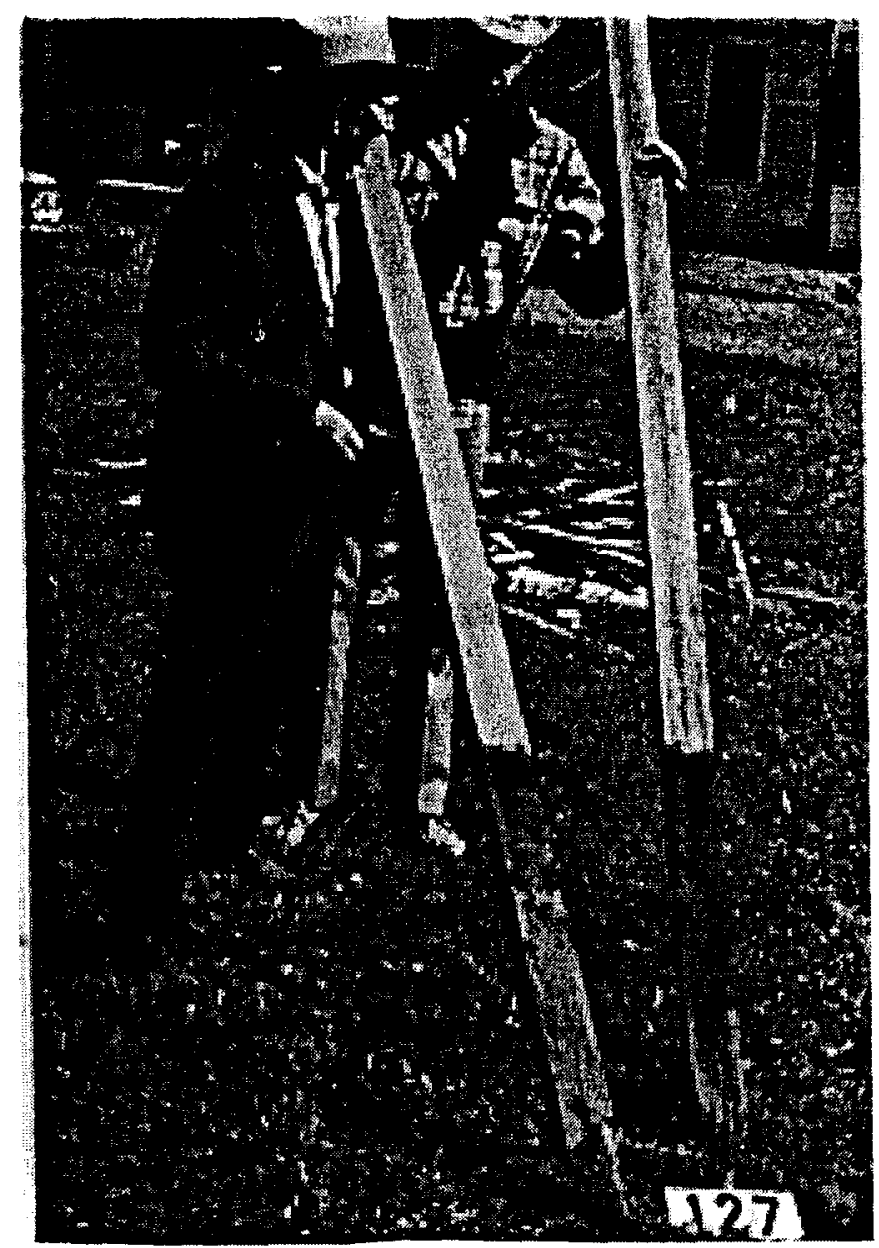

FIGURE 2.6 TIMBER PLANKS (2X4 PENETRTE 3-ft GROUND IN HUBBARD, TEXAS (F2, 1973)

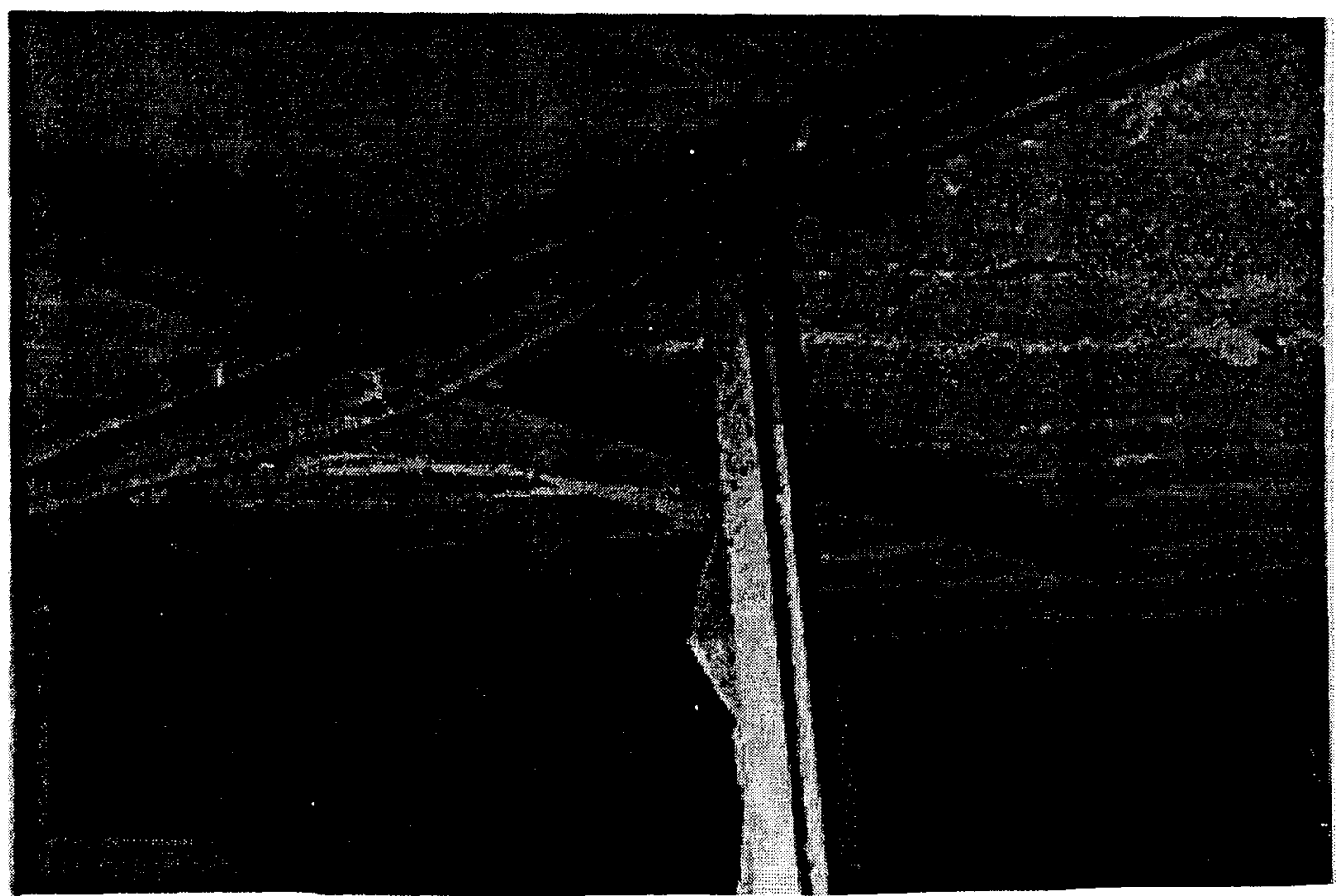

FIGURE 2.7 A 2X4 TIMBER PLANK SLICES BETWEEN CEILING CHANNEL AND WINDOW FRAME IN BOISSIER CITY, LOUSIANA (F5, 1978) 


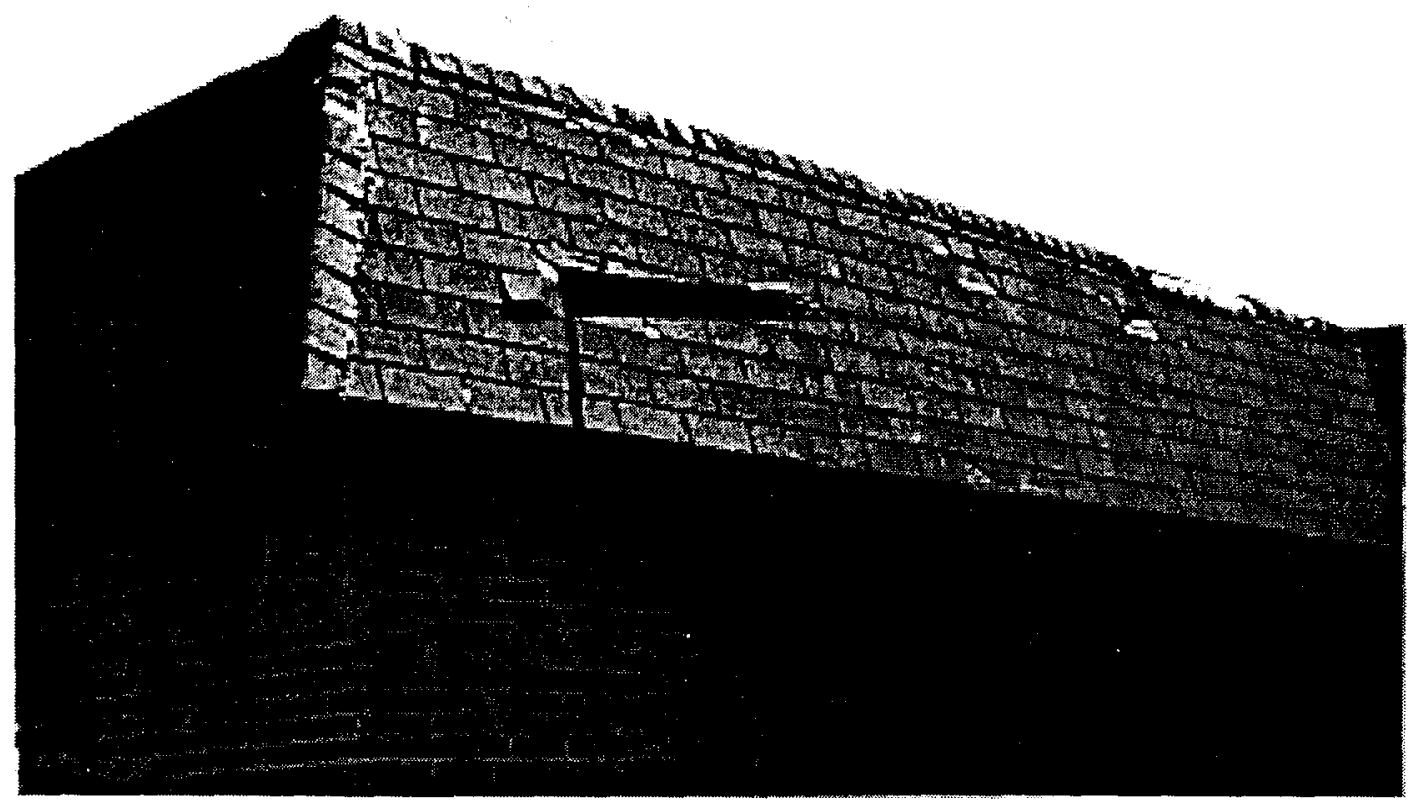

FIGURE 2.8 TIMBER PLANK PENETRATES MANSARD ROOF IN WICHITA FALLS, TEXAS (F4, 1979)

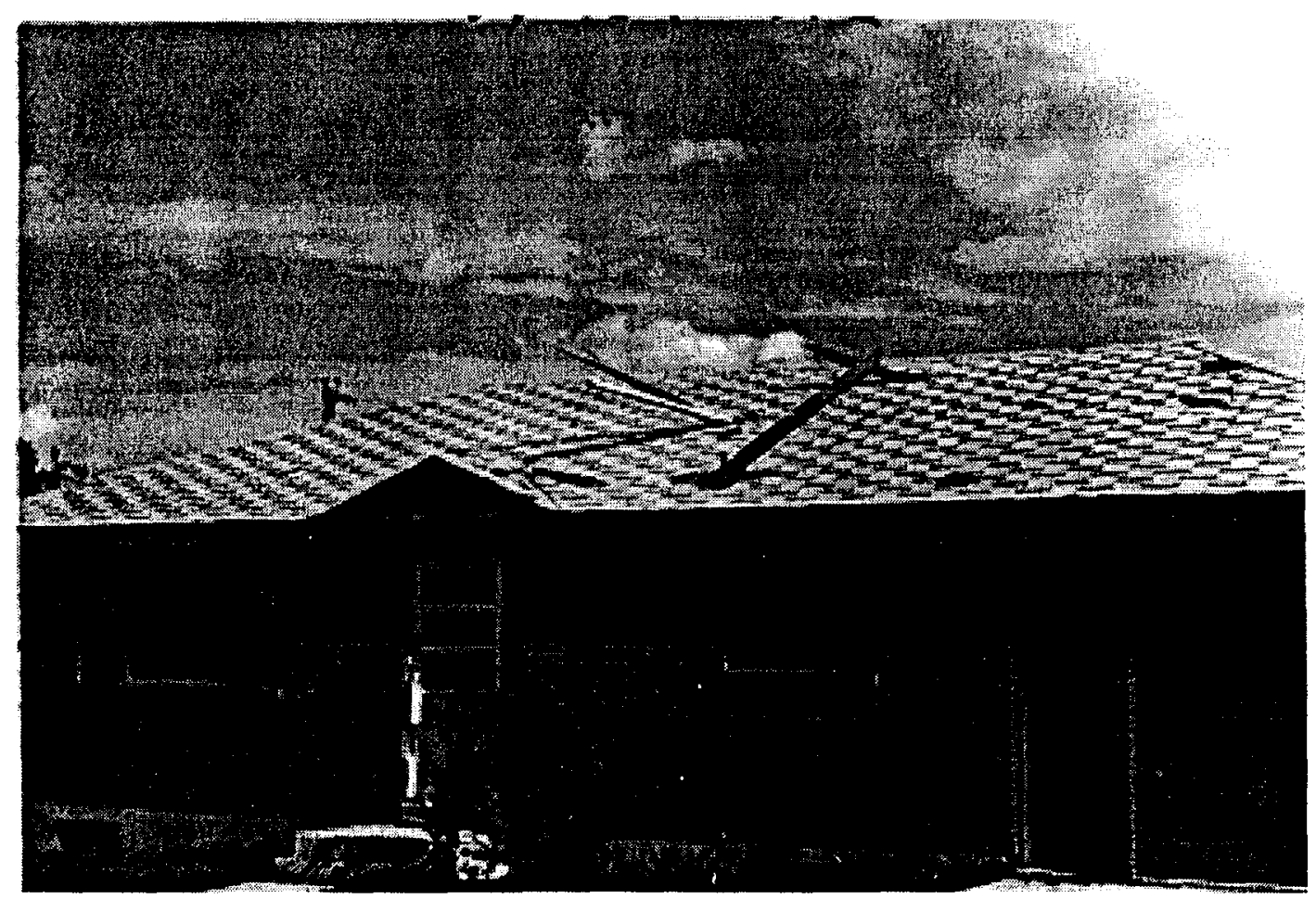

FIGURE 2.9 TIMBER PLANKS PENETRATE RESIDENTIAL ROOF IN CHEYENNE, WYOMING $(F 4,1979)$ 
Wyoming (F3); several timber planks penetrated the roof of a residence. The one nearest the eave in is a $1 \times 6$ wood board. Figure 2.10 in Altus, Oklahoma, AFB. (F3); a $2 \times 6$ timber sliced through an unreinforced concrete block wall in.

\section{Other Debris}

Figure 2.11 shows assorted debris generated by the Altus, Oklahoma, AFB tornado. In addition to various pieces of wood, a section of a utility pole, a roof exhaust vent, and pieces of sheet metal can be seen in the photo. The weight of the broken utility pole is estimated at $110 \mathrm{lbs}$.

A piece of plywood sliced through the rear fender of an automobile in Figure 2.12. Other Debris, including sheet metal, aluminum angles, and pieces of timber, can be seen in the photo. Again, various pieces of debris have collected against the school bus shown in Figure 2.13 (Bossier City, Louisiana, F4). Pieces of plywood, a metal door made from a steel plate, a broken piece of furniture, sheet metal, and pieces of wood are visible in the photo.

\section{Poles and Pipe}

Poles and pipe are often found in the rubble, but they are not as common as the previously examined timber planks. A steel pole along with some timber planks and pieces of plywood are seen in Figure 2.14 (Omaha, Nebraska, F4). The documentation narrative did not indicate how far the pole had traveled. Another light pole was observed in Omaha, Nebraska (F4) (Figure 2.15). The anchor bolts appear to have been sheared off. A two-in. diameter steel pipe penetrated the wall of this residence in Plainview, Texas (F3) as shown in Figure 2.16. Figure 2.17 shows a 3-in. dia. steel pipe 


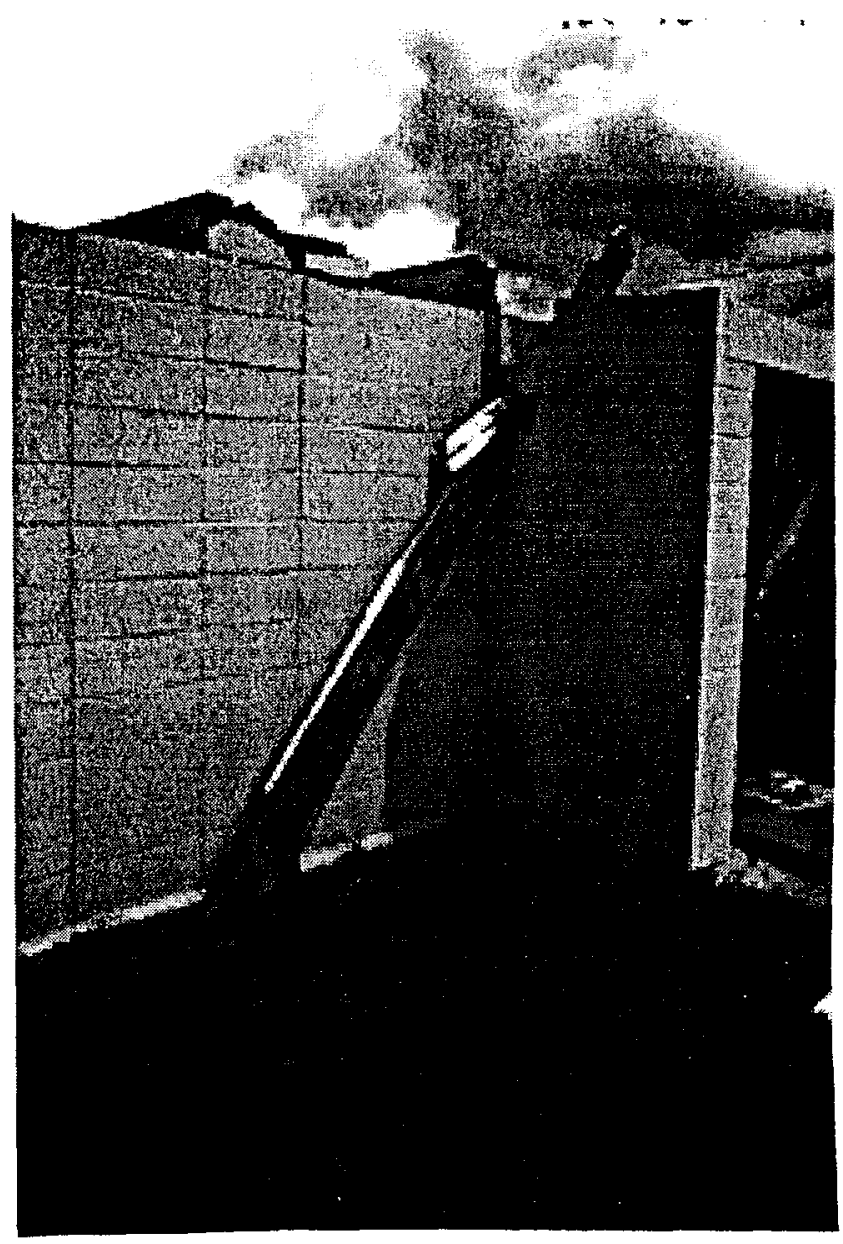

FIGURE 2.10 A 2X6 TIMBER PLANK SLICES THROUGH UNREINFORCED CONCRETE BLOCK WALL AT ALTUS AFB, OKLOHOMA (F3, 1982)

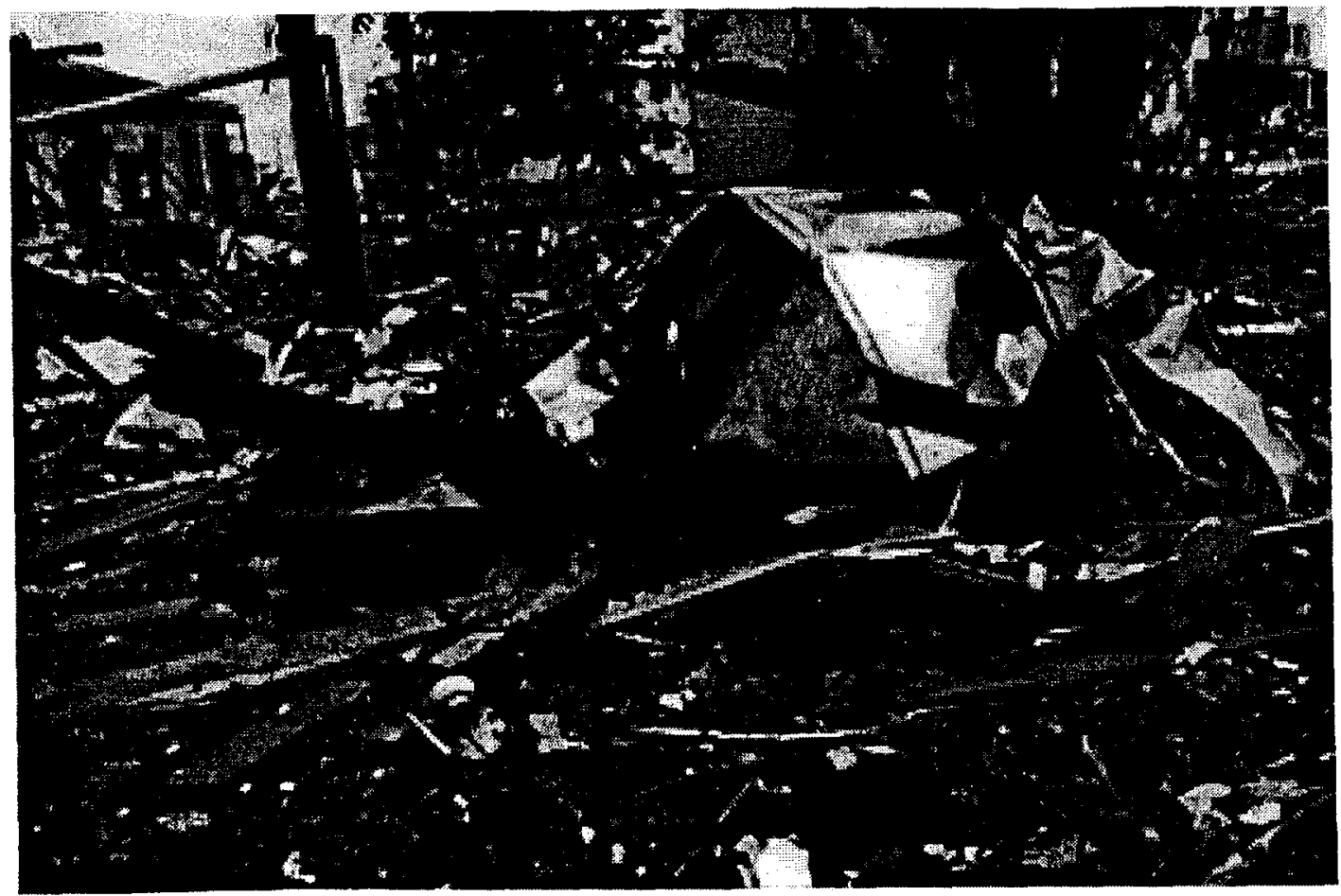

FIGURE 2.11 VARIOUS DEBRIS FOUND IN THE ALTUS, OKLOHAMA AFB TORNADO (F3, 1982) 


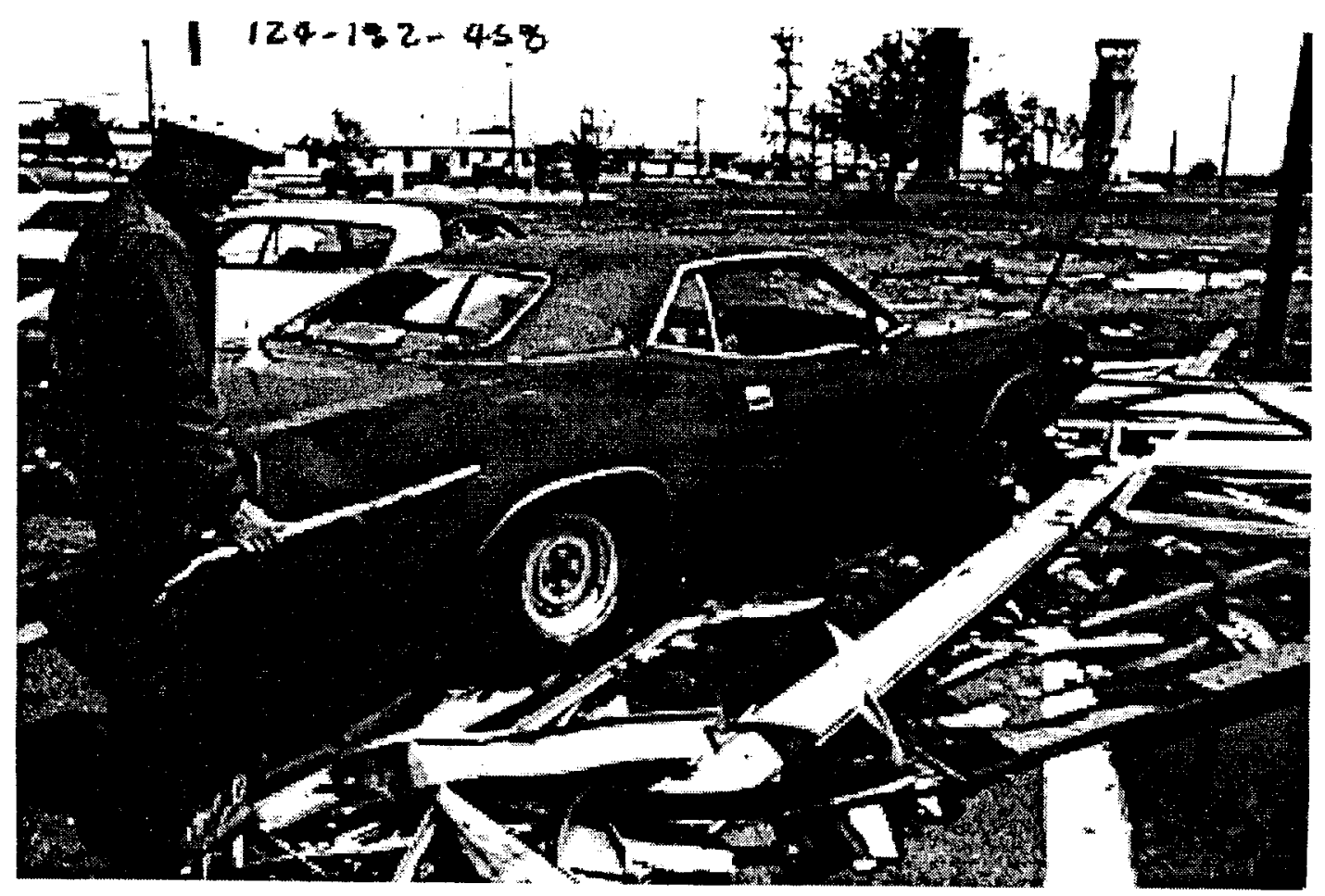

FIGURE 2.12 A PIECE OF 1/2-in.THICK PLYWOOD SLICES THROUGH REAR FENDER OF AUTOMOBILE IN ALTUS, OKLAHOMA AFB (F3, 1982)

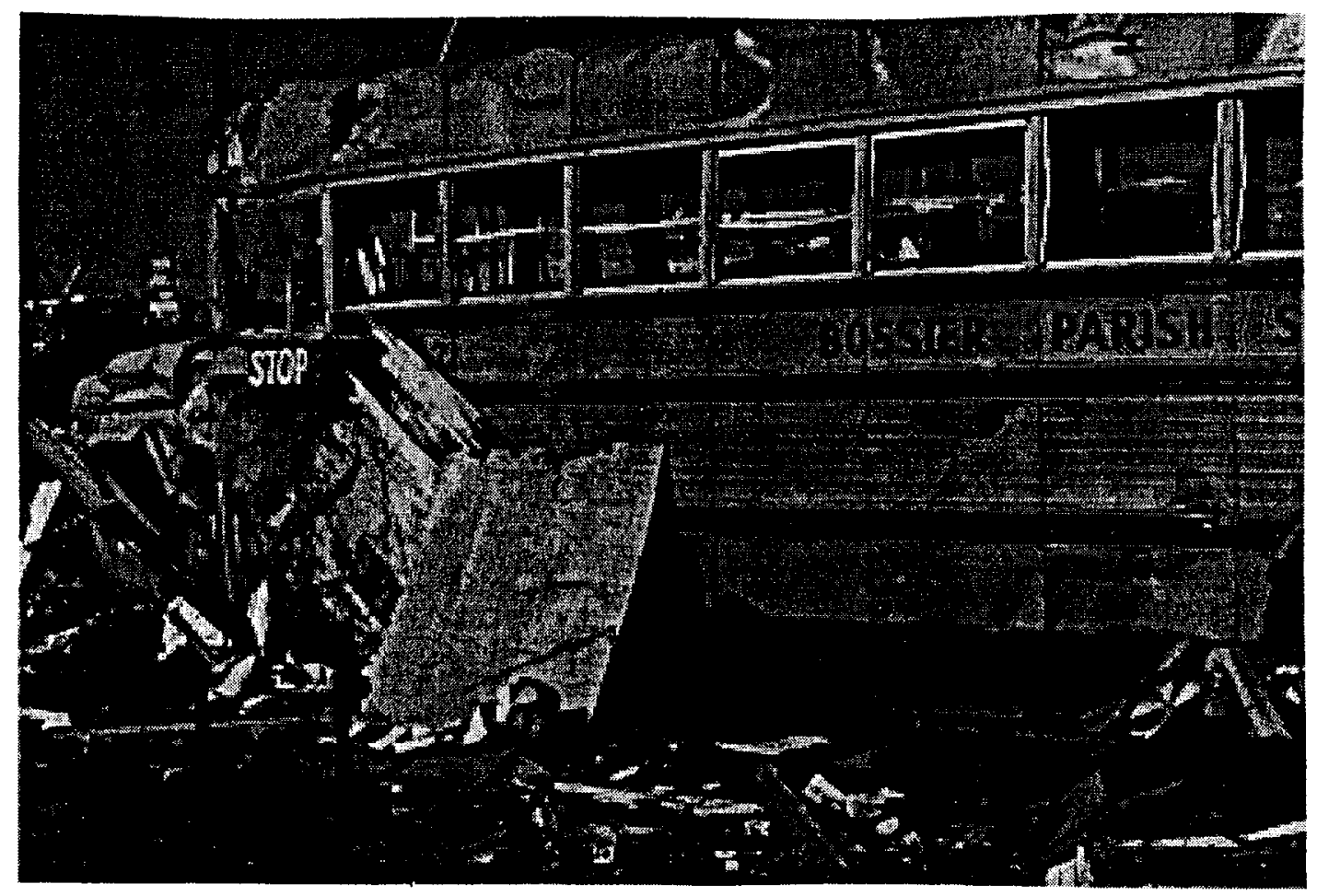

FIGURE 2.13 VARIOUS PIECES OF DEBRIS HAVE COLLECTED AGAINIST SCHOOL BUS IN BOSSIER CITY, (F5, 1978) 


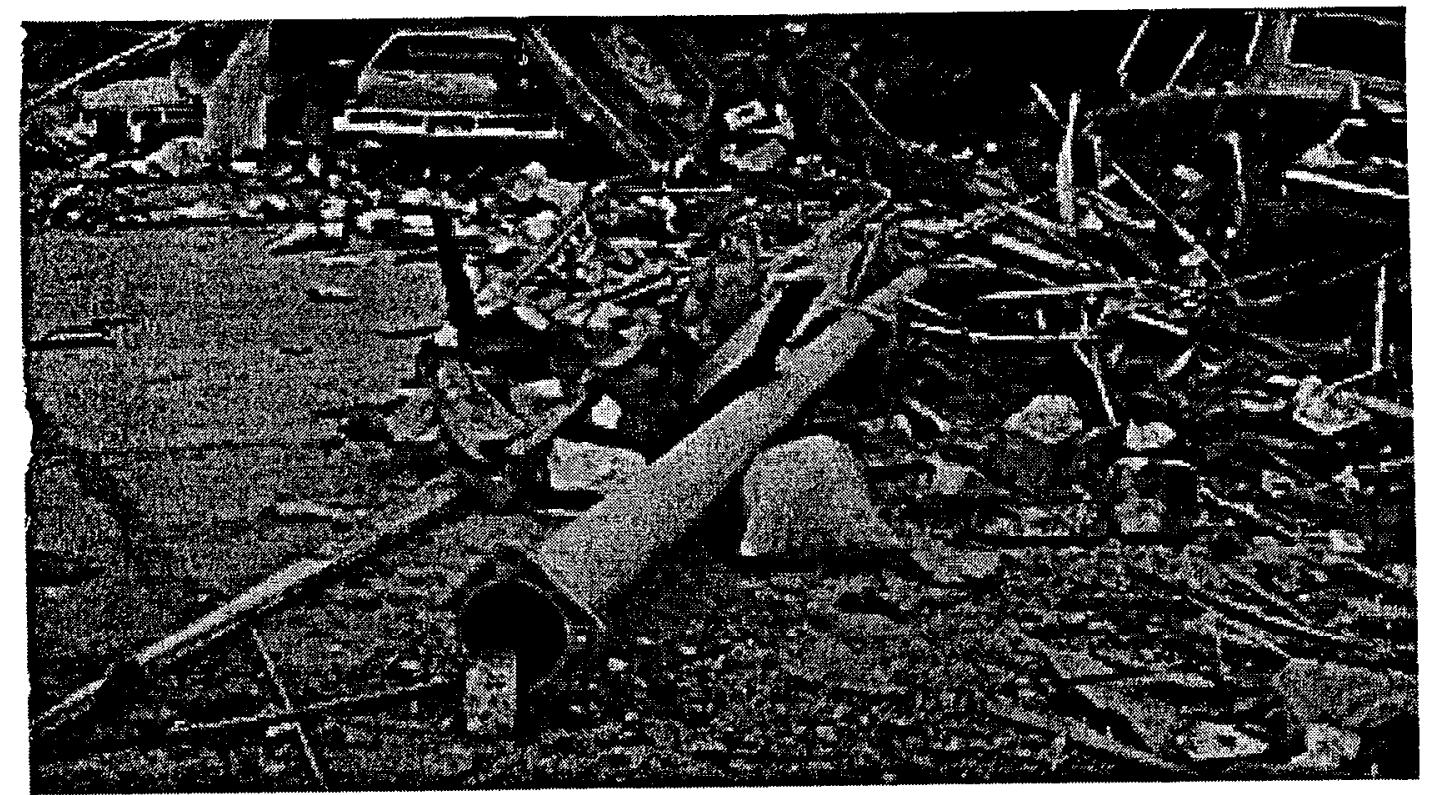

FIGURE 2.14 STEEL LIGHT POLE WAS RIPPED FROM ITS FOUNDATION IN OMAHA, NEBRASKA (F4, 1975)

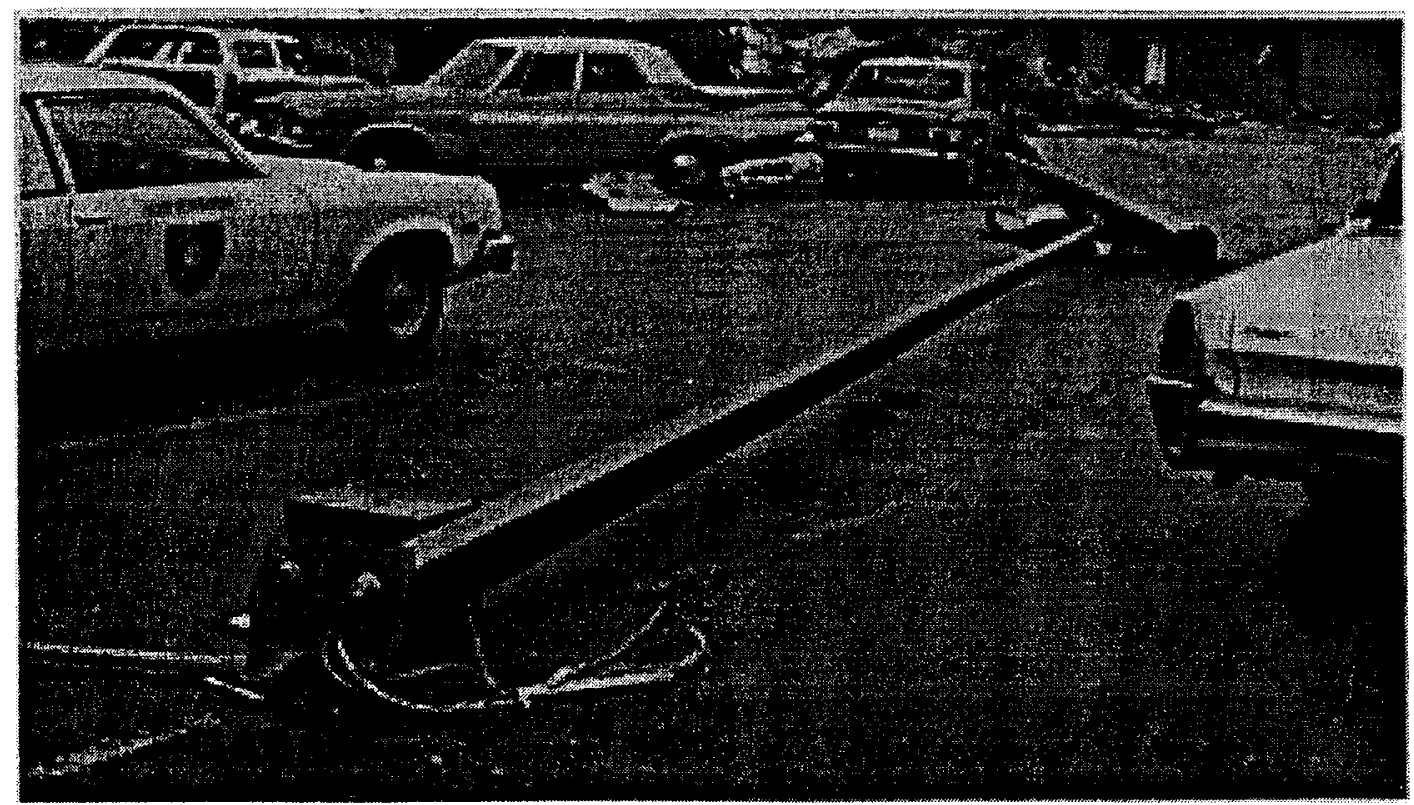

FIGURE 2.15 ANCHOR BOLTS OF THIS LIGHT POLE HAVE SHEARED OFF, OMAHA, NEBRASKA (F4, 1975) 


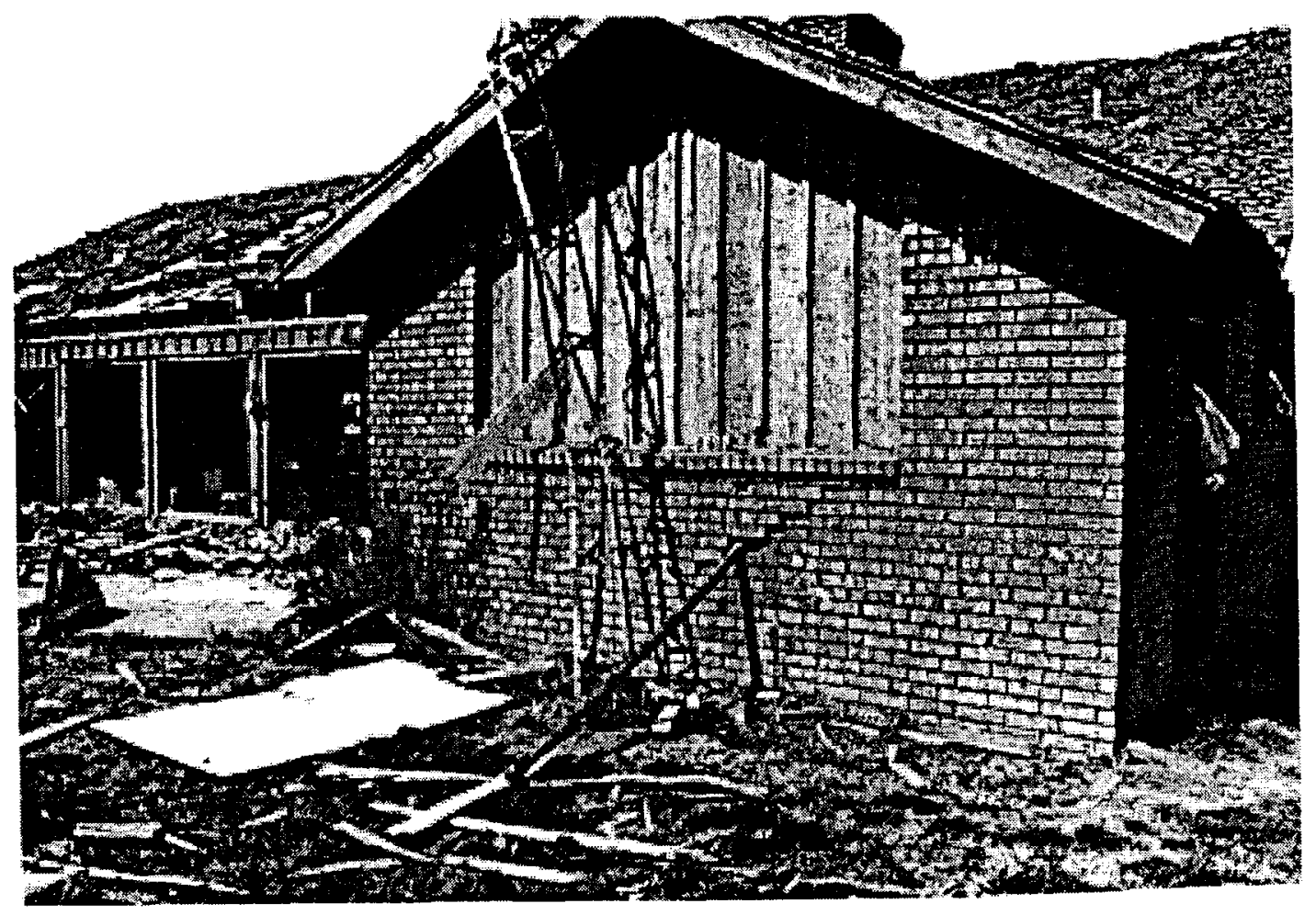

FIGURE 2.16 A 2-in. dia. PIPE PENETRATED RESIDENTIAL WALL IN PLAINVIEW, TEXAS (F3, 1973)

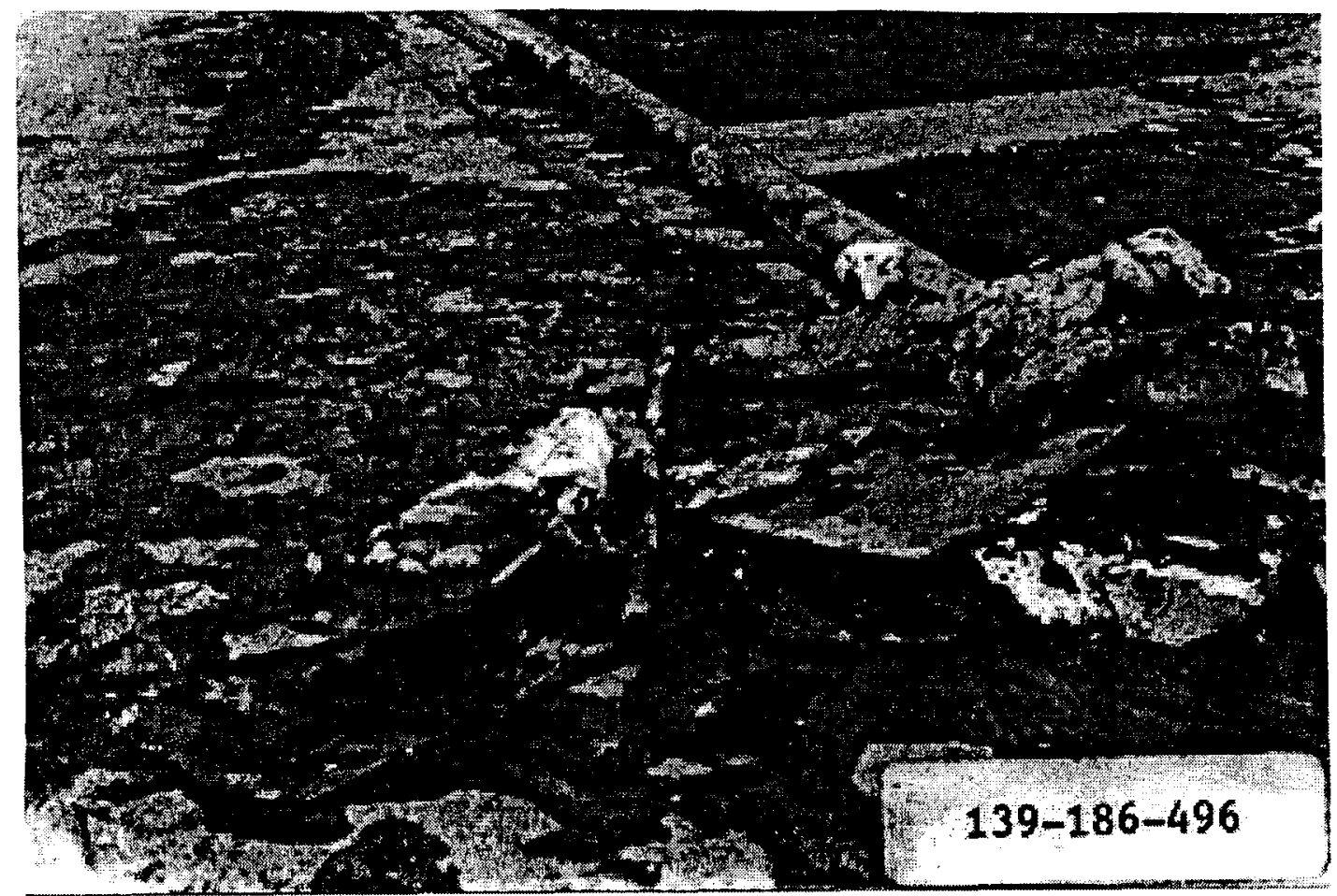

FIGURE 2.17 THIS 3-in. dia. STEEL PIPE (APPROXIMATELY 75 lb) WAS TRANSPORTED BY THE SWEETWATER, TEXAS TORNADO (F3, 1986) 
approximately $10 \mathrm{ft}$. long. This pipe is estimated to weigh 75 lbs. A 2-in. dia. pipe (or electrical conduit) penetrated the ground in Figure 2.18 (Hubbard, Texas, F2).

\section{Automobiles}

Automobiles are frequently rolled and tumbled by tornadic winds. The van shown in Figure 2.19 (Omaha, Nebraska, F4) was reported in the media to have flown over a five-story hospital. The van had been parked on one side of the building before the storm and was found on the opposite side of the building after the storm. Careful examination of the ground surrounding the hospital revealed parts and pieces (including a license plate) of the van that provided evidence it had rolled and tumbled around the building, not flown over it.

Figure 2.20 shows an automobile that was slammed against a steel pole. The point where the automobile struck the pole suggests that the automobile was rolling and tumbling along the ground at the time of impact.

\section{Incredible Missiles}

Heavy missiles include standard steel sections and concrete masonry bond beams. The wide flange steel beam shown in Figure 2.21 is $24 \mathrm{ft}$ long and weighs $720 \mathrm{lbs}$. It penetrated 8-ft into the ground. The missile and five others were observed in Bossier City, Louisiana (F4) (additional discussion found in section 3.7.1). The steel wide flange is one of the largest missiles ever observed in a tornado damage path. The missile traveled approximately $450 \mathrm{ft}$ before penetrating into the relatively soft ground. 


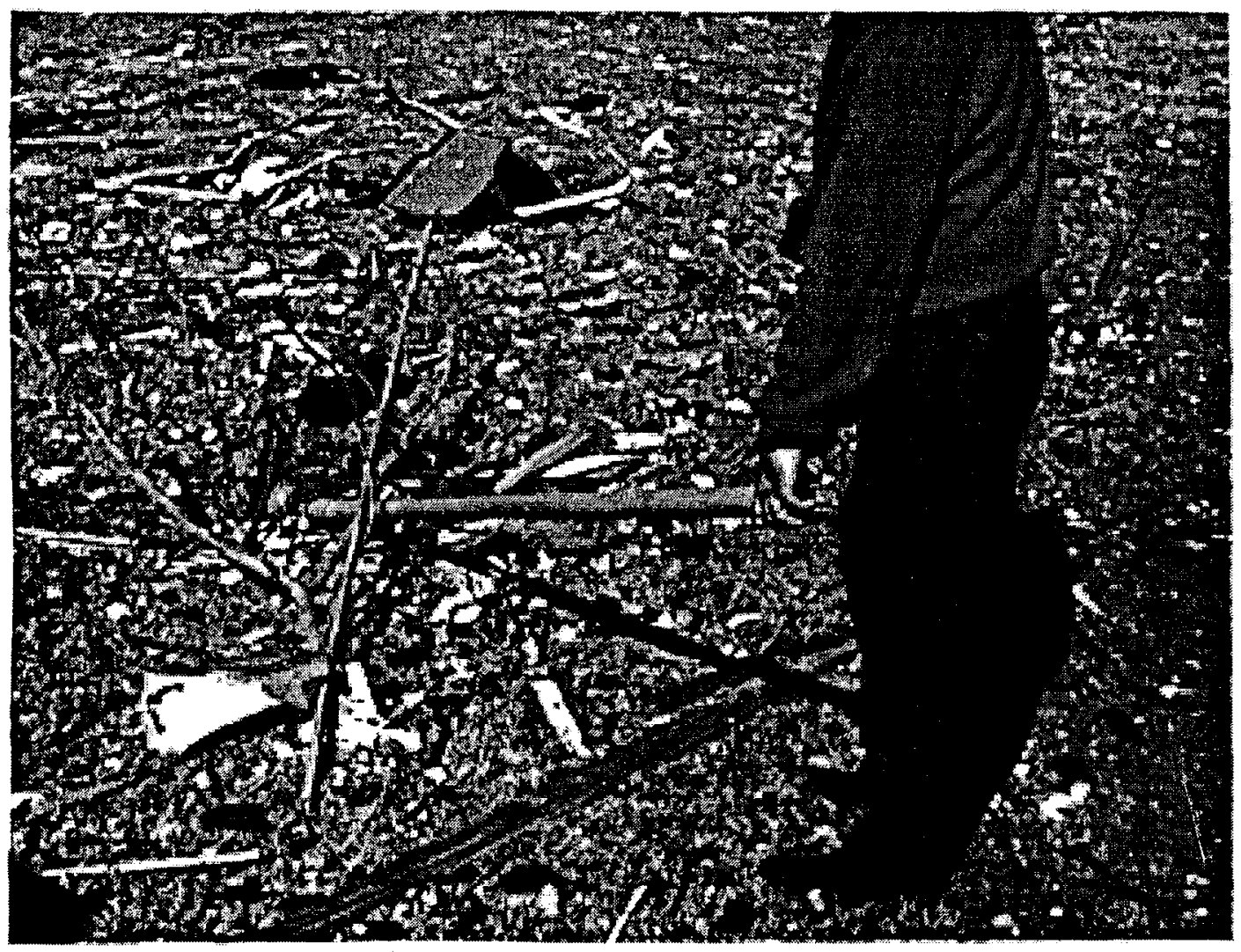

FIGURE 2.18 2-in dia. ELECTRICAL CONDUIT PENETRATED THE GROUND IN HUBBARD, TEXAS TORNADO $(F 2,1978)$ 


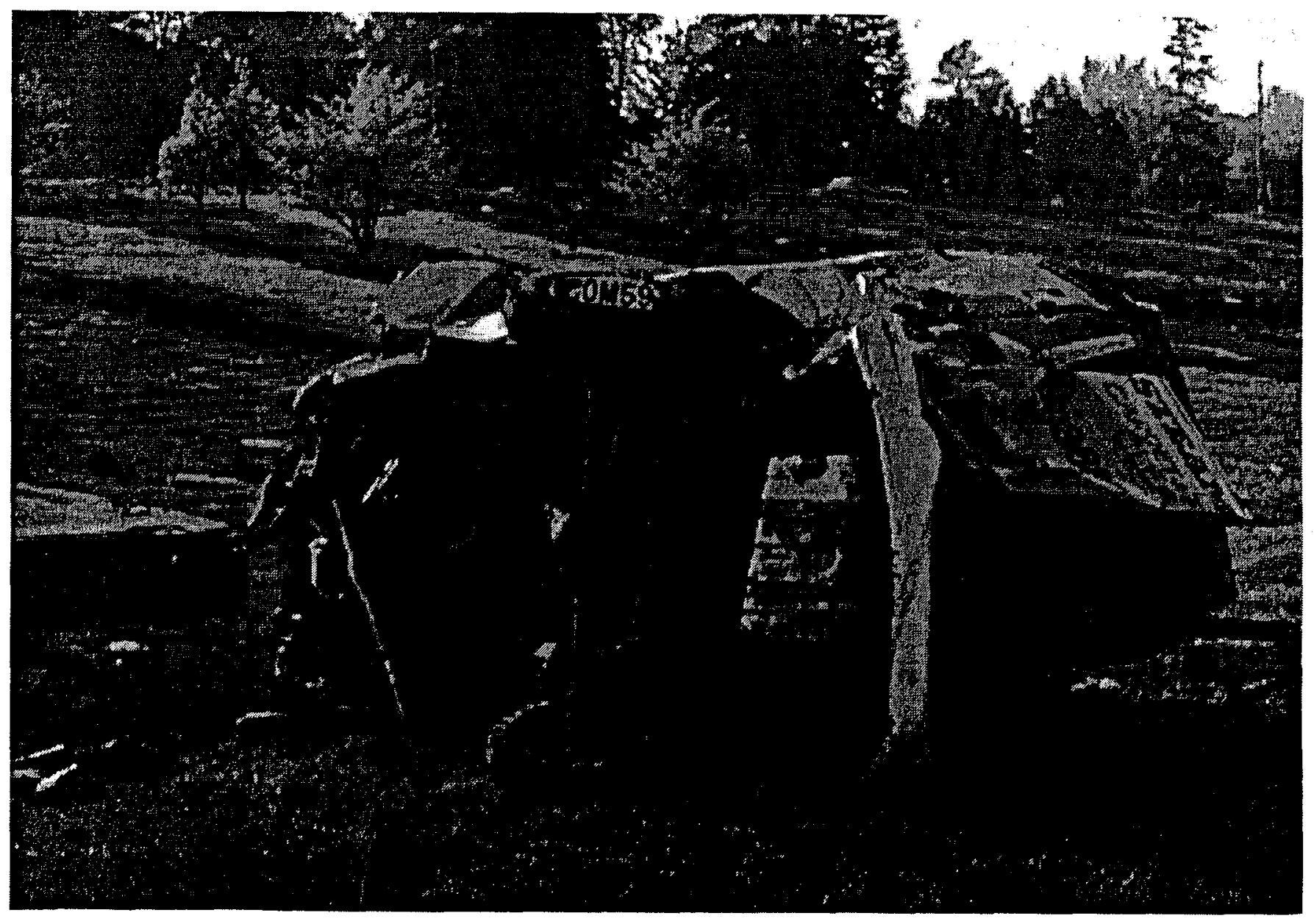

FIGURE 2.19 A VAN ROLLED AND TUMBLED AROUND HOSPITAL IN OMAHA, NEBRASKA TORNADO (F4, 1975) 


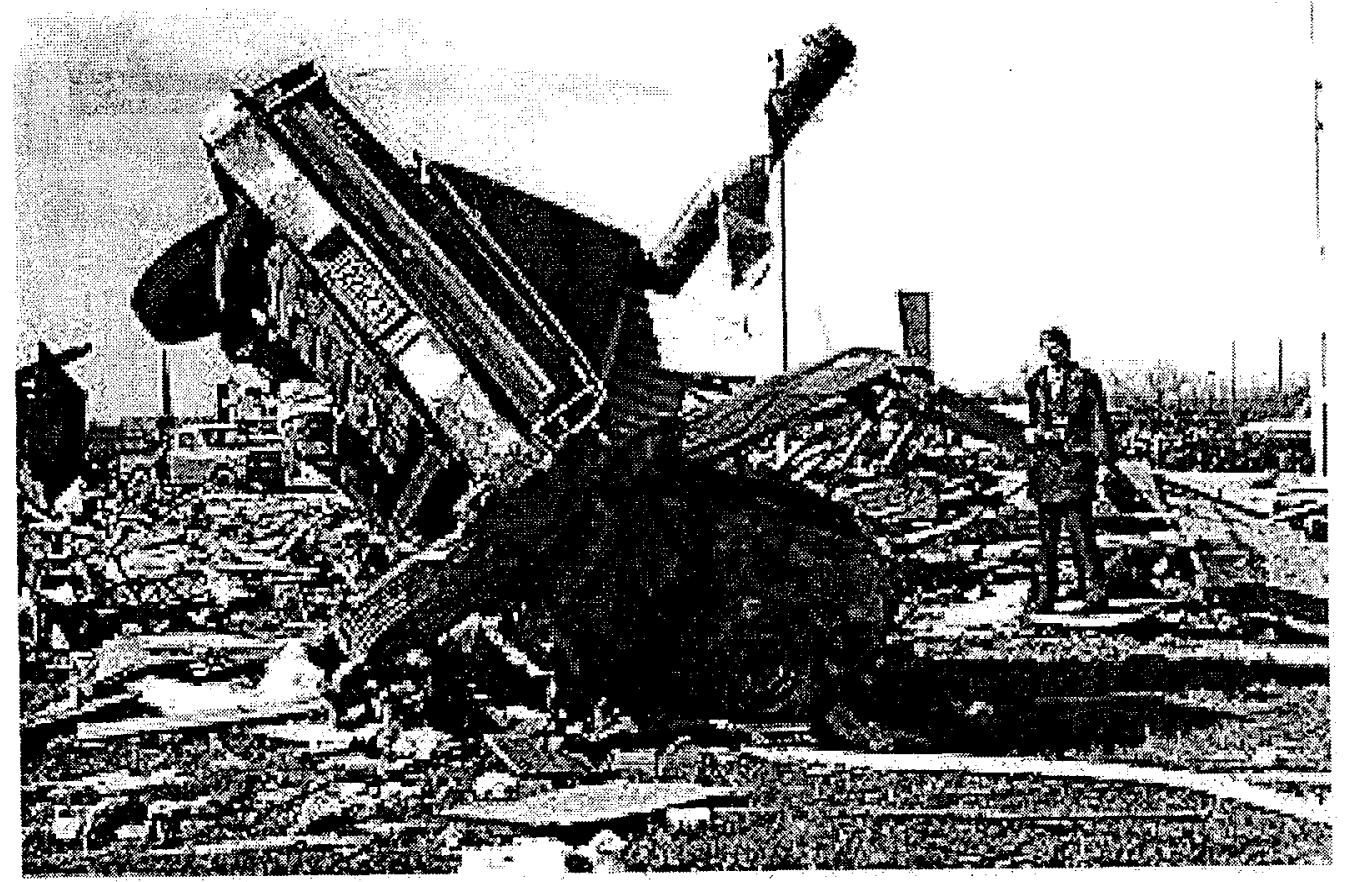

FIGURE 2.20 AN AUTOMOBILE THAT WAS SLAMMED AGAINST A STEEL POLE IN BOSSIER CITY, LOUISIANA (F5, 1978)

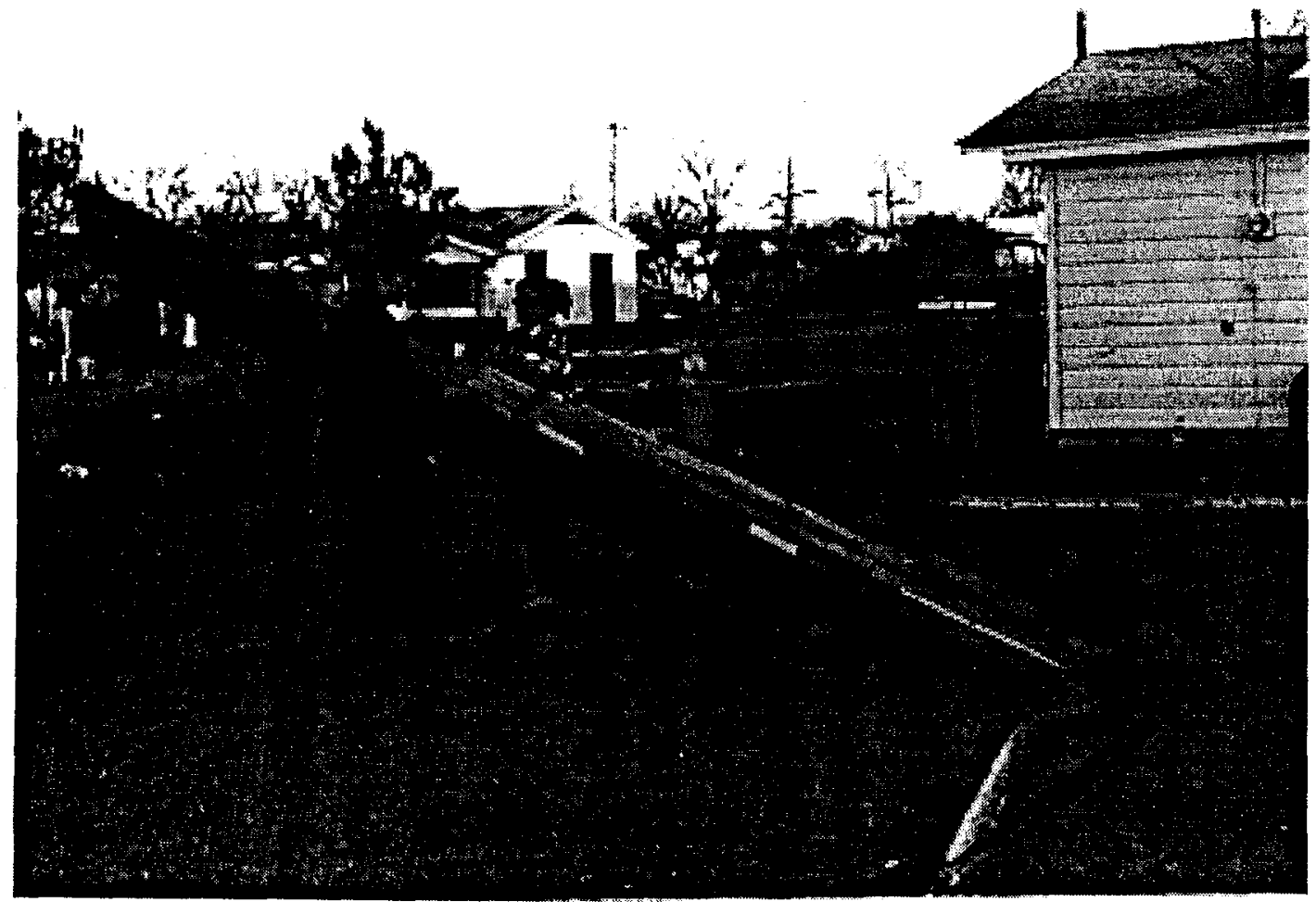

FIGURE 2.21 STEEL WIDE-FLANGE BEAM TRANSPORTED 450-ft FROM ORIGINAL LOCATION IN BOSSIER CITY, LOUISIANA (F5, 1978) 
A bond beam was uplifted from the top of a wall and became airborne when the roof of a building was uplifted by the Altus AFB, Oklahoma, tornado (F3) (see Figure 2.22). Roof joists were anchored into the bond beam, but there was no vertical reinforcement in the wall to prevent the bond beam from being lifting with the roof.

\subsection{Distribution of Timber Missiles}

Field studies of tornado damage indicate that a majority of the missiles originate from the roofs of timber residences and light commercial structures. In all the tornadoes surveyed, pieces of wood plank constituted an overwhelming majority of the missiles observed. The reason for this is that the sources of these missiles are building roofs, which experience higher wind loading than any of the other building components. The wood plank missile itself has a relatively aerodynamically high flight parameter, which enables it to be easily transported by the tornado winds.

A quantitative assessment of the wood plank missile was carried out for three selected tornadoes: Hubbard, Texas in 1973 rated F2, Sweetwater, Texas in 1986 rated F3, and Wichita Falls, Texas in 1979 rated F4. The goal of this investigation was to determine the relative prevalence of the various sizes of wood plank missiles and hence validate or reject a $2 \times 4$ wood plank as a design basis missile.

Figures $2.23,2.24$, and 2.25 contain the aerial photos taken at the three tornado events. Individual pieces of timber plank were identified in the photos. Dimensions were estimated by scaling features of known dimensions on the photographs. The missile width was estimated from its relative size in the aerial photo. The missile thickness was assumed based on the type of structures in the aerial photo. Tables A-1, A-2, and A-3 in 


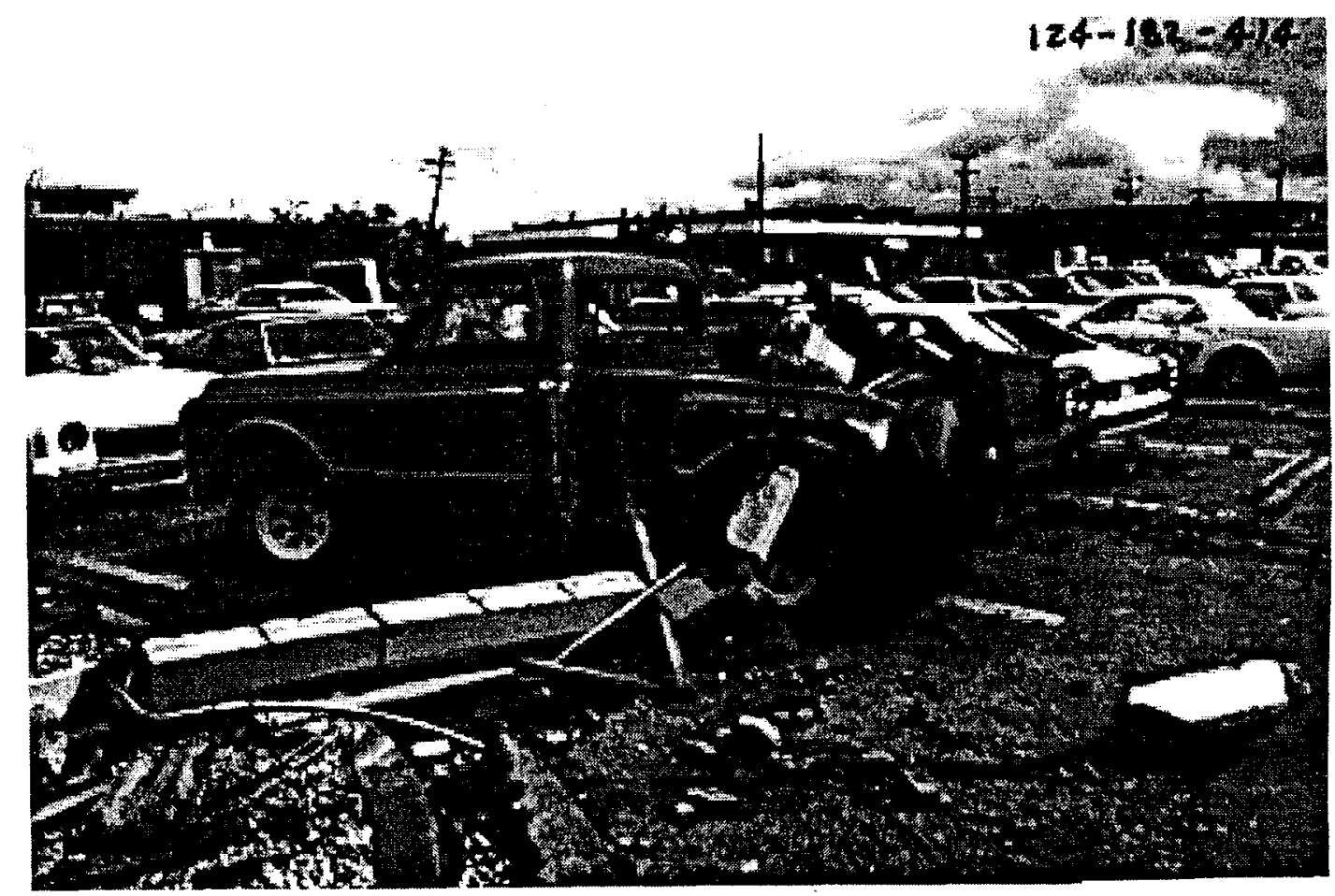

FIGURE 2.22 A BOND BEAM WAS LIFTED FROM THE TOP OF A CONCRETE BLOCK WALL IN ALTUS AFB, OKLAHOMA TORNADO $(F 4,1982)$

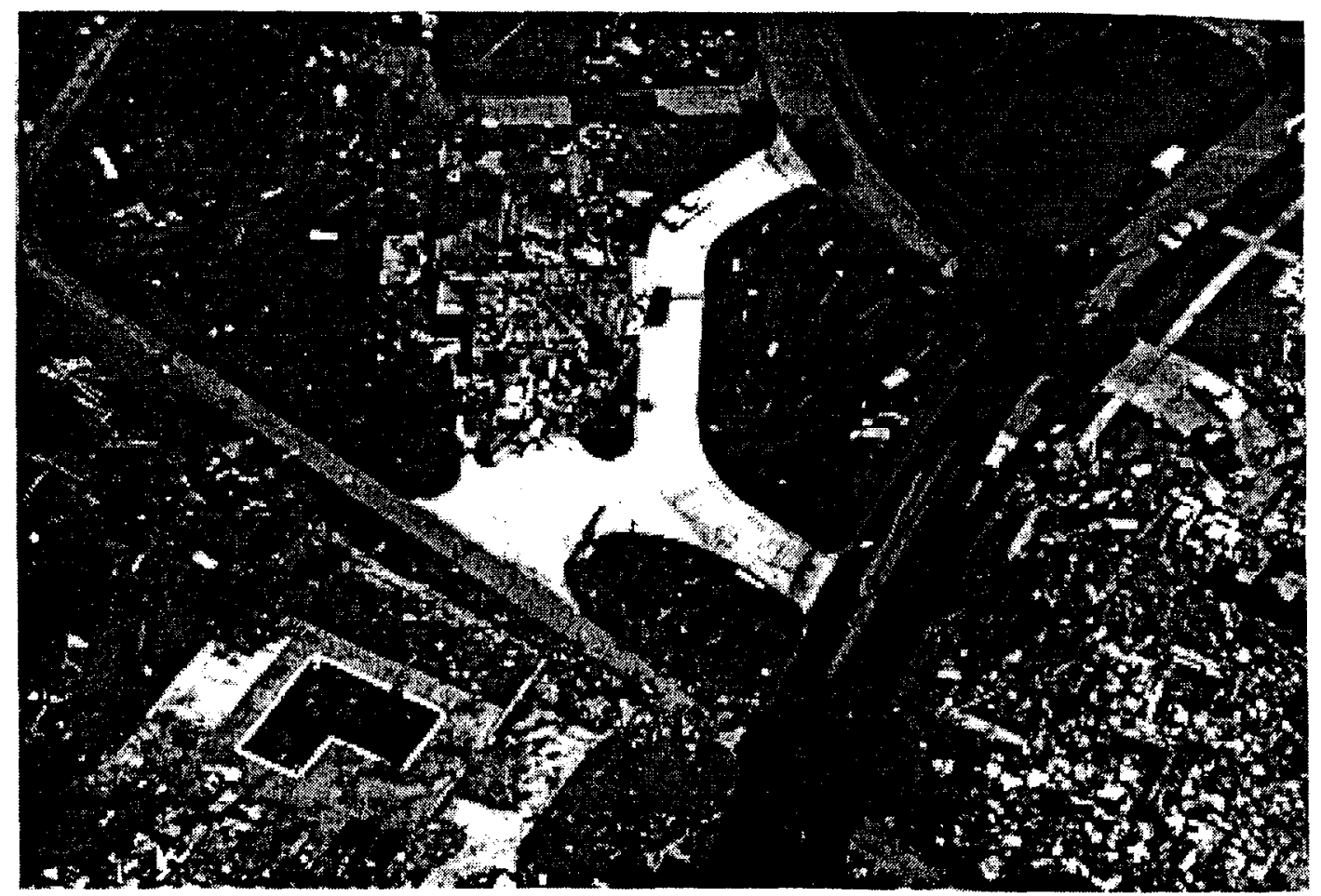

FIGURE 2.23 AERIAL VIEW OF HUBBARD, TEXAS TORNADO DAMAGE PATH (F2, 1973) 


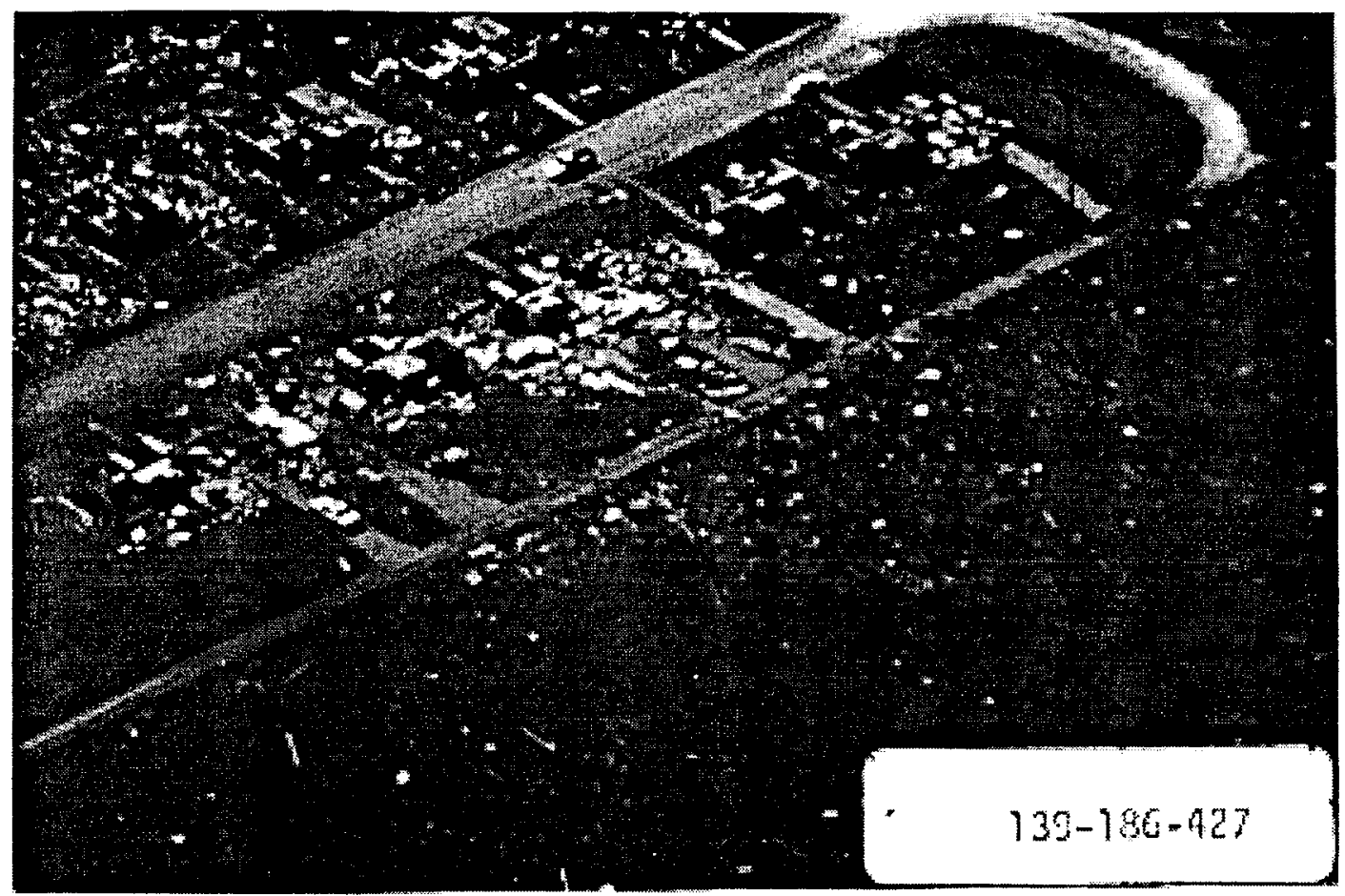

FIGURE 2.24 AERIAL VIEW OF SWEETWATER, TEXAS TORNADO DAMAGE PATH (F3, 1986)

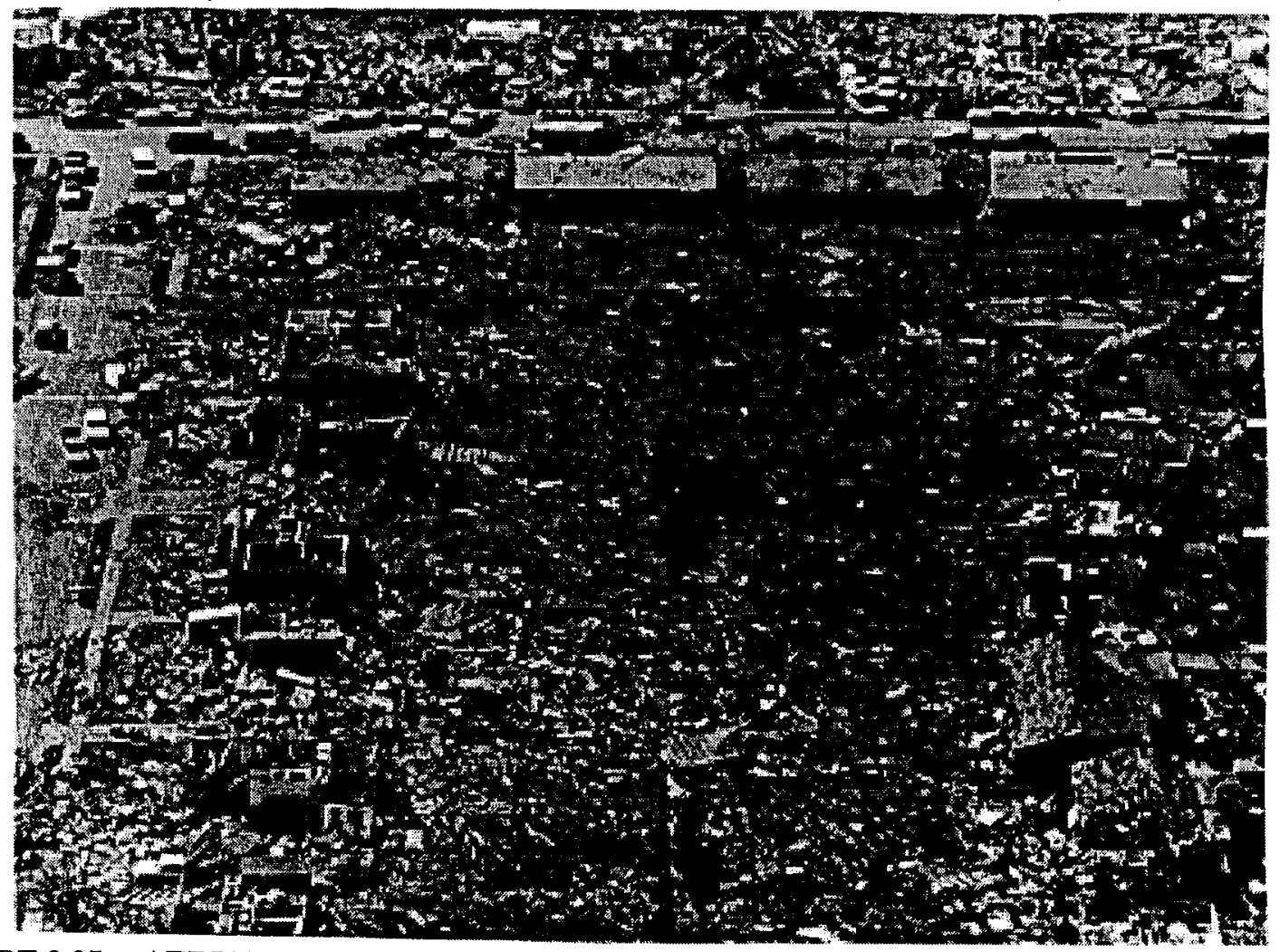

FIGURE 2.25 AERIAL VIEW OF WICHITA FALLS, TEXAS TORNADO DAMAGE PATH (F4, 1979) 
Appendix A. tabulate the estimated sizes of the wood plank missiles and their weights for Hubbard, Texas, Sweetwater, Texas and Wichita Falls, Texas respectively. Mean lengths, and sample sizes from the three aerial photos are summarized in Table 2.4.

Table 2.4 Data Summary for Wood Missiles

\begin{tabular}{|c|c|c|c|}
\hline Tornado & Sample Size & $\begin{array}{c}\text { Mean Length of } \\
\text { Wood Missile(ft) }\end{array}$ & $\begin{array}{c}\text { Mean Weight of } \\
\text { Wood Missile(lb) }\end{array}$ \\
\hline $\begin{array}{c}\text { Hubbard, Tx } \\
\text { (F2) }\end{array}$ & 70 & 5.44 & 7.74 \\
\hline $\begin{array}{c}\text { Sweetwater, TX } \\
\text { (F3) }\end{array}$ & 88 & 6.20 & 8.32 \\
\hline $\begin{array}{c}\text { Wichita falls, TX } \\
\text { (F4) }\end{array}$ & 143 & 6.94 & 9.20 \\
\hline
\end{tabular}

The DOE missile criteria for SSCs (Table 1.1) specifies $2 \times 4$ timber missile which weighs $15 \mathrm{lb}$. This implies that for the mean weights of all observed missiles to correspond to the $2 \times 4$ wood missile, the observed mean weights corresponding to the observed mean lengths of $5.44 \mathrm{ft}, 6.20 \mathrm{ft}$, and $6.94 \mathrm{ft}$, should be, respectively: $6.80 \mathrm{lb}$, $7.75 \mathrm{lb}$, and $8.68 \mathrm{lb}$ for the three tornadoes. The unit weight assumed by the DOE criteria is $34.3 \mathrm{lb}$ per $\mathrm{cu}$. $\mathrm{ft}$. It only remains to show that the observed mean weights of $7.74 \mathrm{lb}$, $8.32 \mathrm{lb}$, and $9.20 \mathrm{lb}$, respectively for the three tornadoes, are not significantly different from the corresponding $2 \times 4$ weights.

The $95 \%$ confidence limits on the observed mean weights were calculated using the usual formula for the large samples and unknown standard deviation:

$$
\bar{x} \pm t_{\alpha / 2}\left(\frac{s}{\sqrt{n}}\right)
$$


where

$$
\begin{aligned}
& \mathrm{x}=\text { sample mean } \\
& \mathrm{s}=\text { sample standard deviation } \\
& \mathrm{n}=\text { sample size } \\
& \mathrm{t}_{\alpha / 2}=\text { confidence limit at the } \alpha \text { percent level }
\end{aligned}
$$

Significance tests on the mean weights were also carried out to test:
1) $H_{0}: \mu=6.80$
2) $\mathrm{H}_{\mathrm{o}}: \mu=7.75$
3) $\mathrm{H}_{\mathrm{o}}: \mu=8.68$

$\mathrm{H}_{1}: \mu \neq 6.80$

$\mathrm{H}_{1}: \mu \neq 6.80$

$\mathrm{H}_{1}: \mu \neq 6.80$

where

$$
\begin{aligned}
& \mathrm{Ho}=\text { null hypothesis } \\
& \mathrm{H}_{1}=\text { alternate hypothesis }
\end{aligned}
$$

The results are tabulated in Table 2.5. It can be seen from Table 2.8 that the weights for the $2 \times 4$ missile fall within the $95 \%$ confidence bounds.

Table 2.5. Confidence Limits and significance Test Results

\begin{tabular}{|c|c|c|c|c|c|c|}
\hline Tornado & $\begin{array}{c}\text { Observed } \\
\text { Mean } \\
\text { Missile } \\
\text { Weight(lb) }\end{array}$ & $\begin{array}{c}\text { 95\% } \\
\text { Confidence } \\
\text { Limit } \\
\text { LCL UCL }\end{array}$ & $\begin{array}{c}\text { Mean wt. } \\
\text { of 2x2 } \\
\text { Missile } \\
\text { (lb) }\end{array}$ & $\begin{array}{c}\text { Mean wt. } \\
\text { of 2x4 } \\
\text { Missile } \\
\text { (lb) }\end{array}$ & $\begin{array}{c}\text { Mean wt. } \\
\text { of 2x6 } \\
\text { Missile } \\
\text { (lb) }\end{array}$ & $\begin{array}{c}\text { P-value for } \\
\text { Test of } \\
\text { Significance }\end{array}$ \\
\hline $\begin{array}{c}\text { Hubbard, } \\
\text { TX (F2) }\end{array}$ & 7.74 & 6.768 .74 & 3.40 & 6.80 & 10.20 & 0.07 \\
\hline $\begin{array}{c}\text { Sweetwater } \\
\text { TX } \\
\text { (F3) }\end{array}$ & 8.32 & 7.359 .29 & 3.88 & 7.75 & 11.63 & 0.26 \\
\hline $\begin{array}{c}\text { Wichita } \\
\text { Falls, TX } \\
\text { (F4) }\end{array}$ & 9.20 & 8.519 .88 & 4.34 & 8.68 & 13.01 & 0.14 \\
\hline
\end{tabular}


At the significance level $\alpha=0.05$, the test of significance leads us not to reject the $\mathrm{H}_{\mathrm{o}}$ hypothesis in each case; i.e., we have no evidence to say that the mean weights of all the missiles are not the same as those corresponding to the mean weights of $2 \times 4$ missiles. Use of the $2 \times 4$ wood missile as the design basis missile is therefore validated.

\subsubsection{Other Missiles}

The observation presented in section 2.3 indicates objects and debris other then timber missiles that can be treated as two distinct classes of tornado missiles. These missiles are heavier than the timber plank and do not fly as readily as the planks.

One class of missiles is represented by the 3-in. diameter schedule to steel pipe. The pipe represents TV antenna poles, electrical conduits, clothlines posts, fence posts, steel roof joints, water and gasoline pipes and small rolled steel sections. These item do not occur frequently enough to conduct an exercise similar to the one for the timber planks. The 3-in. pipe weighing $75 \mathrm{lb}$ was chosen based on experience and judgement to represent the close missiles. A pipe was chosen because it is easier to replicate impact test than with other non-circular shapes.

The third close of tornado missiles included automobiles, light trucks, vans, buses, trailers, track dumpsters and storage tanks. Many automobiles are observed upside down or on their sides, suggesting a rolling, tumbling mode of transport. The argument for the tumbling mode of transport is reinforced by the relatively low flight parameter for these shapes. Based on observations and judgement, a $3000 \mathrm{lb}$ automobile is representative of this class of missiles. 


\subsection{Missiles that Did Not Fly}

Some missiles do not fly because their aerodynamic flight parameter, $C_{D} A / W$ (where $C_{D}$ is an aerodynamic drag coefficient, $A$ is the cross sectional area normal to the relative wind direction, and $\mathrm{W}$ is the missile weight), is small. The loose items lying on the ground in Figure 2.26 were not picked up and transported, even though some have relatively large flight parameters. The wind speed increases as the tornado approaches, but the potential missiles are pushed along and collect against buildings, trees or automobiles, as in shown in Figures 2.12 and 2.13.

Heavy missiles in the USNRC missile spectrum (6-in. diameter steel pipe, 12-in. diameter steel pipe and utility poles) might fly in the $360 \mathrm{mph}$ USNRC design basis tornado, but they are rarely observed in tornadoes rated F3 or F4. The steel beam in Figure 2.21 was an exception. It along with five others, flew in a F4 tornado wind speed reached approximately $100 \mathrm{mph}$ and then were suddenly released. This action gives each missile an impulse load, causing it to accelerate rapidly.

There are other reasons why missiles do not fly in an intense tornado. The highest wind speed in a tornado occupies only a small part of the damage path area (see Figure 3.5). Thus even though an intense tornado passes over a potential heavy missile, it may not release because it does not experience winds of sufficient intensity to release and transport the missile. Racks of pipe of various sizes were passed over by the Washita, Oklahoma tornado (F3) and were not picked up and transported. The Brandenberg, Kentucky, tornado (F5) (1974) passed over a rack of utility poles by they did not fly. Several were blown off the rack, but remained on the ground. In the same storm, $2 \times 4$ in lumber pieces were picked up from stacks in a lumber yard and transported several miles. 


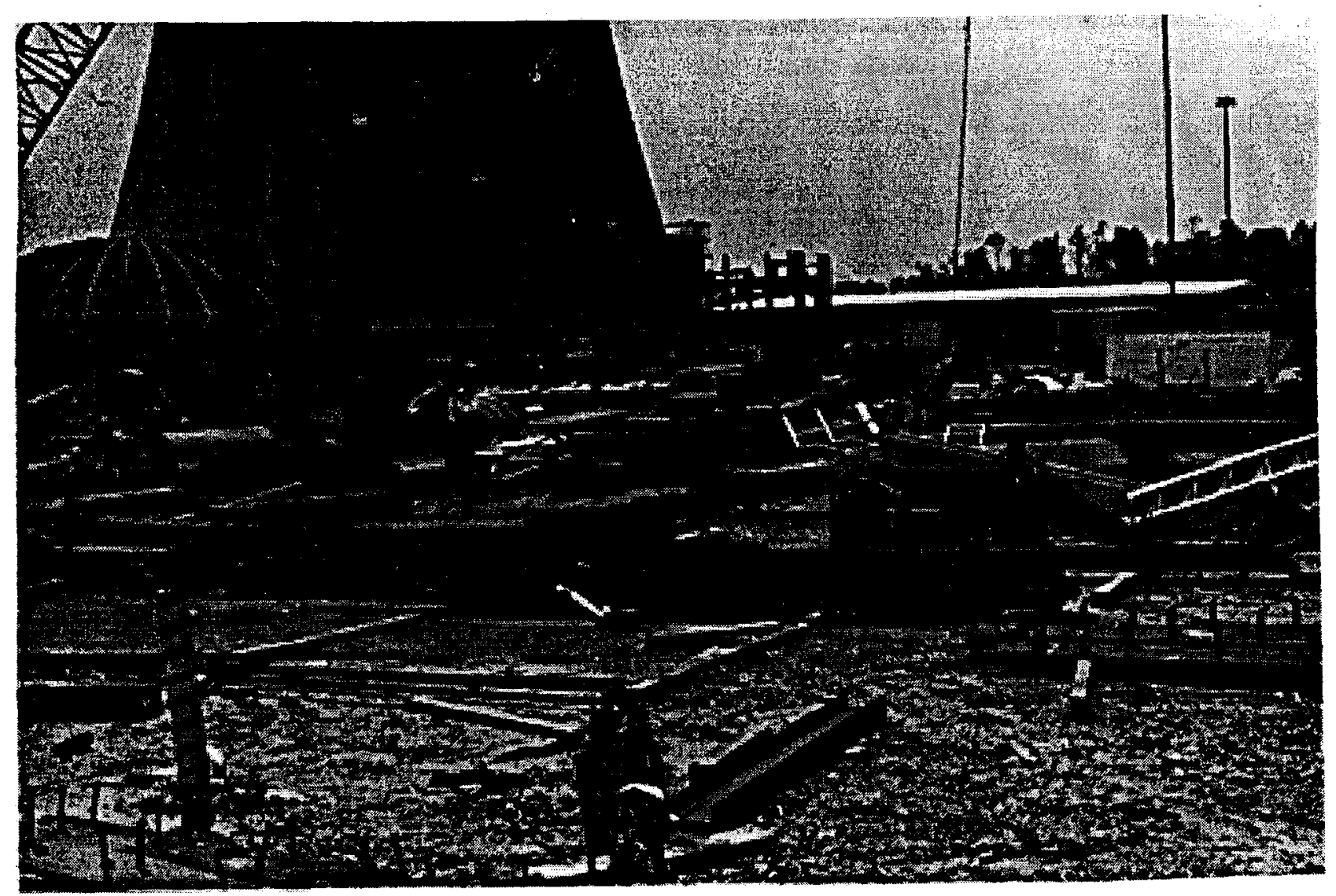

FIGURE 2.26 LOOSE OBJECTS LYING ON THE GROUND ARE NOT PICKED UP BY TORNADO WINDS, GRAND GULF, MISSISSIPPI (F3, 1978) 


\subsection{Recommended Missiles}

\subsubsection{Tornado Missiles}

Many different missiles have been observed in field investigations of tornado damage. The missiles that have been observed in F2, F3, and F4 tornadoes fit into three categories that can be represented by:

- $2 \times 4$ timber plank

- 3-in. diameter steel pipe

- Automobile

The $2 \times 4$-timber missile represents the many pieces of wood from damaged or destroyed structures. In addition wood plank represents other light to medium weight objects such as plastic pipe, electrical conduit, and small diameter pipes. The 3-in. steel pipe represents a class of missiles observed in the field, including TV antenna, clotheslines posts, large direction feve? Posts, open ? steel joints? Electrical conduit and small steel rolled sections. The automobile is representation of other objects that roll and tumble in the mid ? trash dumpster, light trailer and storage tanks.

A survey of timber missiles observed in three tornadoes, rated F2, F3 and F4, suggest mean weights of $6.70,7.75$, and 8.68 for the $2 \times 4$ missile. Significance tests show that the mean weights of all missiles in each storm are not significantly different than the $2 \times 4$ missile weights. Thus, it is appropriate to use the $2 \times 4$ as a design missile. Because of other objects represented by the $2 \times 4$ classification, with a weight greater than the mean weight of the $2 \times 4$. Hence, a weight of 15 pound is recommended to represent the $2 \times 4$ missile classification. 
The 3-in. diameter pipe represents a class of missiles that are not lifted significantly by the winds, but can be accelerated horizontally as they fall to the ground from their initial elevation due to gravity. Objects by the 3-in. diameter pipe missile can be represented by a 75 -pound weight.

Missiles represented by the automobile roll and tumble along the ground. There is no field evidence to support their being lifted to high elevations. Stories of flying automobiles and trucks are sometimes printed in the news media, but in cases investigated by Texas Tech University personnel, there was no scientific evidence to support these claims. The mass of automobile missiles will produce a structural response failure of wall panels and columns upon impact.

Thus, from field observations, the following design missiles are recommended for tornado design of SSCs in the PC3 and PC4 categories:

$2 \times 4$ Timber weighing $15 \mathrm{lb}$

3-in. Diameter Schedule 40 steel pipe-weighing $75 \mathrm{lbs}$

Automobile weighing $3000 \mathrm{lbs}$

The impact speeds of the recommended missiles are obtained in Chapter 3.

\subsubsection{High Wind Missiles}

Straight winds and hurricane winds are less intense than tornado winds. In addition, straight wind and hurricane winds do not have the strong vertical component observed in tornadoes. Missiles observed in straight wind and hurricane damage are in the class represented by the $2 \times 4$ timber. Typical damage includes broken window glass, perforation of metal panel walls and stud walls with various wood, aluminum and vinyl 
cladding. Thus, the $2 \times 4$-timber missile is selected for high wind design criteria. The recommended impact speeds are obtained in Chapter 3. 


\section{COMPUTER SIMULATION OF TORNADO MISSILE TRAJECTORIES}

\subsection{Introduction}

Before the missile speeds can be defined and before impact resistance of various materials used in construction can be evaluated, information is needed on the flight trajectories of missiles that are transported by tornadoes. In addition to identifying the types and sizes of missiles, information is needed on the speed and height achieved by the missiles as they are transported by the tornado winds. Their means of injection into the tornado and simulation of the missile trajectories are needed for design or evaluation of SSCs.

As with the determination of most tornado characteristics, direct measurements are difficult, if not impossible. Damage investigation following a destructive tornado reveals the origin and final location of a missile, but determining its trajectory from the field observations is almost impossible. Occasionally, a rolling or tumbling automobile or trash dumpster will leave evidence of its path by marks on the ground, but if the object becomes airborne, its speed and trajectory cannot be determined in the field.

Motion pictures of tornadoes sometimes show large pieces of debris being transported by the tornado winds. Hoecker (1960) tracked sheets of plywood which were picked up by the Dallas tornado of 1957 . Through photogrammetric analysis techniques, he was able to deduce velocities achieved by pieces of plywood. Hoecker used the calculated missile speeds to estimate wind speeds in the Dallas tornado. Photogrammetric analyses have not produced sufficient data for establishing tornado missile design criteria to date. For this reason, researchers resorted to tornado missile 
trajectory simulations to obtain the needed information. This chapter describes a study. conducted at Texas Tech University.

\subsection{Objectives}

The primary objective of this study is to estimate the probable speed achieved by the two tornado missiles ( $2 \times 4$ timber plank and 3-in. diameter steel pipe) identified in Chapter 2 for design and evaluation of DOE SSCs in tornadoes of various intensities. The estimates include the horizontal speeds and the vertical speeds of the missile, which are of interest in designing walls and roofs, respectively. The maximum height above ground that the missile reaches also is of interest. Missile speeds and trajectories are estimated by means of computer simulation of the tornado-missile interaction in the wind field.

A tornado missile trajectory simulation code developed at the Institute for Disaster Research is used for trajectory calculations. Tornadoes of various intensities are passed over an array of missiles that are uniformly spaced across the tornado path. A trajectory calculation is made for each missile in the path. At each time step, the missile's position in space, its speed and its acceleration are calculated by the numerical technique. Depending upon the location within the tornado path, some missiles are transported, while others remain stationary. The tornado wind speeds must reach certain minimum value before the missile is released from its restraint in a building or structure. Tornado intensities are expressed in terms of the Fujita Scale (Fujita, 1971). Statistical analyses of the computer-generated data on missile speeds associated with various probability levels. 
The scope of this study is limited to the timber plank and steel pipe missiles, although the method is applicable to other objects. As shown in Chapter 2, objects representative of medium weight missiles are by far the most common ones found in damage to residential and commercial construction.

\subsection{Requirements for Missile Trajectory Simulation}

There are two basic requirements for tornado missile trajectory simulation:

1. the transport of a tornado missile is a random event that depends on a number of factors, and

2. each parameter affecting tornado missile transport has a range of values that affects the trajectory outcome.

Random factors that affect the transport of a missile include:

1. characteristics of the tornado wind field,

2. location of missile within tornado path,

3. degree to which missile is restrained, and

4. physical characteristics of the missile.

Characteristics of a tornado wind field that affect missile transports are maximum wind speed, variation of wind speed within the tornado wind ficld (assumed wind ficld model), radius of maximum wind speed, and transnational wind speed. Wind speed varies across the width of a tornado path. Most tornado wind field models including the one used in this study assume that the maximum wind speed occurs at some distance from the tornado path centerline (radius of maximum wind speed). From this point, the wind speed decays with increasing distance from the centerline. The edge of the tornado path is defined at the 75-mph wind speed boundary. 
A missile becomes airborne more readily if it is restrained as the tornado approaches and then suddenly releases when the wind speed reaches a certain value. Wind forces overcome the restraint and the missile is released for transport by the winds. Because the release wind speed for planks and pipes are typically greater than $75 \mathrm{mph}$, all missiles distributed across the tornado path will not be transported by the winds.

The physical characteristics of missiles that affect their tendency to fly include shape, surface area, and weight. Aerodynamic drag on the missile produces the wind forces that cause it to translate and lift. Medium weight missiles have a relatively large surface area-to-weight ratio, which allows them to be transported more easily than heavyweight missiles.

Parameters that affect tornado missile transport includes tornado wind speed, translational wind speed, initial height of missile above ground and the missile release wind speed. Each of these parameters affects the missile speed and its trajectory.

\subsection{Literature Review}

There have been numerous attempts to simulate tornado missile trajectories and thus obtain information on maximum speeds achieved by certain types of missiles as well as the heights above ground attained by them.

Studies of tornado missiles in the late 1960s and early 1970 s were attempts to establish criteria for the design of nuclear power plants. Most missiles considered were in the heavywcight category (large diameter pipes, utility poles, automobiles), although missiles in the medium-weight category (timber planks, pipes and rods) also were included in the studies. Missile trajectory simulations were performed by Bates and 
Swanson (1967), Paddleford (1967), Lee (1973), Burdette at al., (1974) and Beeth and Hobbs (1975).

The missiles were treated as particles (three-dimensional model). Hoecker's (1960) analysis of the Dallas tornado of 1957 was used to define the tornado wind field models. Different assumptions were made on injection mechanism and initial position of the missiles relative to the tornado path. A variety of values of drag and lift coefficients were assumed. As a result of the different assumptions, a wide range of maximum missiles impact speeds were calculated, depending on the particular set of missile and wind field parameters assumed.

Redmann et al. (1976) introduced a six-degree-of-freedom (rigid) model for missile trajectory calculations. While the model has distinct advantages over the particle model in that it is possible to account for lift forces independently of drag forces, the model is more complex and requires additional aerodynamic coefficients (Castello, 1976). Drag, lift and rotation coefficients as a function of missile orientation in space (pitch, yaw and roll) were determined from the wind tunnel tests (Redmann, et al., 1976).

While a six-degree-of-freedom model has the potential of more accurately predicting actual missile motion, Costello (1976) speculated that given knowledge of the wind field and aerodynamic coefficients, it might be that rotations about one or two axes will not significantly affect the trajectory. This would certainly seem to be a reasonable conjecture concerning rotation of a slender body about its long axis.

Iotti (1975) presented a novel approach to the tornado missile problem based on deterministic calculations of tornado missile trajectories using a particle model. By uniformly placing a large number of identical missiles in a volume surrounding the 
tornado center and calculating their trajectories, he determined a probability distribution of missile speeds, which turned out to be nearly normal. Using the missile distribution and the tornado strike probability, he was able to estimate the total probability of a given missile having a velocity larger than some value $\mathrm{V}_{\mathrm{m}}$.

While the basic concept of Iotti is valid, several improvements have been made in recent years. Since 1976, better wind field models have been proposed, more accurate drag and lift coefficients have been obtained, and the concept of minimum wind speed to release a missile from its restrained position has been introduced. This latter concept suggests a different arrangement of the missiles in the tornado path prior to running the trajectory calculations and a slightly different approach to probabilistic assessment. The factors mentioned above are discussed in greater detail in subsequent sections of this document.

Monte Carlo simulation of the tornado missile events is an alternative approach to the missile problem. The basic premise of Monte Carlo simulation is that certain parameters affecting a process are repeatedly selected at random until an adequate sample is obtained for statistical analysis. Johnson and Abbot (1977) performed a Monte Carlo simulation of tornado missiles on the Piligrium 2 Nuclear Power Plant site. The tornado trajectories were calculated using a particle model and deterministic methods. The approach modeled the plant and identified specific impact points on the roof and walls.

The most sophisticated code for Monte Carlo simulation of tornado generated missiles is the TORMIS code by Twisdale and Dunn (1981). The missile targets are modeled so that missile impact points can be visualized. The approach provides excellent estimates of the uncertainties in the model. The two limitations of the code are that site 
specific studies must be performed (as opposed to generic studies) and the degree of sophistication of the model may not be justified in light of available wind and missile data. The approach presented in this study is an alternative to Monte Carlo simulation.

\subsection{Factors Affecting Missile Trajectories}

Tornado generated missile trajectories are determined by computer calculations. The deterministic solution of a tornado missile trajectory involves

1. a tornado wind field model

2. dynamic equations,

3. an aerodynamic flight parameter, and

4. a means of injection. Each item discussed in the paragraphs below.

\subsubsection{Tornado Wind Field Model}

Tornado wind field models can be grouped into two general categories:

1. meteorological models, and

2. engineering models.

Meteorological models attempt to satisfy thermodynamic and hydrodynamic balances associated with tornado dynamics. The objective of an engineering model is to represent the tornado wind field in a simplistic manner that bounds the magnitudes of the various wind components (Lewellen, 1976). The discussion presented herein is restricted to enginecring modcls.

Early wind field models used for tornado missile trajectory studies were based on Hoecker's (1960) analysis of the Dallas tornado of April 2, 1957. The wind field model 
was determined from photogrammetric analyses of movies of the tornado. Bates and Swanson (1967) first used the Hoecker windfiled model to calculate tornado missile trajectories. Other researchers (Lee, 1973 and Burdette et al., 1974) used slightly modified forms of the Bates and Swanson wind field model.

Beeth and Hobbs (1975) and Simiu and Cordes (1976) simplified the wind field model to a combined Rankine vortex for the assumption of tangential wind speed. Simple linear relationship for radial and vertical wind speed components as a function of the tangential wind speed were assumed which did not satisfy continuity of flow.

Fujita (1978) presented wind field models that represent two types of tornadoes observed in the field. The models are based on photogrammetric analysis of tornado movie films, on ground marks left by tornadoes, and on damage patterns observed in post-storm investigations. Fluid mechanics equations of motion and continuity are satisfied and scaling to adjust tornado size and intensity is consistent and has a physical basis. DBT-77 (Design Basis Tornado based on 1977 tcchnology) represents a typical single vortex tornado. DBT-78 represents a multiple-vortex tornado in that it has several small satellite vortices rotating around the center of the parent vortex. The satellite vortices were thought, at one time, to be a principal damaging mechanism (see e.g. Fujita, 1970). They were used to explain cases where one house would have been completely destroyed, while the one next door would have been virtually untouched, even though they were both in the tornado's path.

Studies since the carly 1970's (see e.g. Minor et al., 1977) point out that satellite vortices are very unstable and tend to dissipate over rough terrain (as in a suburban area). Most authorities no longer believe they are a significant factor in tornado damage. 
Hence, they are not considered a significant factor in propelling tornado missiles. For this reason and others, the DBT-77 model is selected as the wind field model for the trajectory calculations in this study. The model has the following advantage over other models used in previous work:

1. Fluid mechanics equations of continuity are satisfied,

2. Flow patterns are consistent with the spatial distribution of flow observed in photogrammetric analysis of tornado movies,

3. The model accounts for the presence of a boundary layer within a few hundred feet of ground, and

4. A minimum number of parameters must be assumed to obtain a complete description of the model.

Details of the Fujita DBT-77 tornado wind field model are given in Appendix D.

\subsubsection{Dynamic Equations}

The dynamic motion of tornado missiles can be modeled with three or six degrees of freedom. For reasons discussed in Section 3.3, a three degree-of-freedom model is selected for this study.

Equation of motion of the missile when subjected to the forces of the wind is well known. The equation can be formulated in either a polar or rectangular coordinate system. A rectangular system is used herein. The drag force acting on the missile is

$$
F=0.5 \rho V_{r}^{2} C_{D} A
$$

where

$\rho$ is mass density of air, slug/ft ${ }^{3}$, 
$\mathrm{C}_{\mathrm{D}}$ is a drag coefficient,

$\mathrm{V}_{\mathrm{r}}$ is the magnitude of the wind vector relative to the missile, $\mathrm{ft} / \mathrm{sec}$, and

$A$ is a specified surface area of the missile, $\mathrm{ft}^{2}$.

Using Newton's second Law of motion, this force is divided by the mass of the missile to obtain the acceleration.

$$
a=F / m=0.5(\rho / m) \mathrm{V}_{r}^{2} C_{D} A
$$

Replacing $\rho / m$ with $y / W$ the equation reduces to

$$
a=0.5 \gamma \mathrm{V}_{r}^{2}\left(C_{D} A / W\right)
$$

where

$m$ is the mass of missile, slugs

is the weight of the missile, and

$\gamma$ is the density of air, $\mathrm{lb} / \mathrm{ft}^{3}$

$\mathrm{C}_{\mathrm{D}} \mathrm{A} / \mathrm{W}$ is called the flight parameter, $\mathrm{ft}^{2} / \mathrm{lb}$.

Recognizing that acceleration is the second derivative of displacement with respect to time, the initial value problem is described by a set of ordinary differential equations which can be solved by integrating forward in time from prescribcd initial conditions until the missile impacts the ground or reaches some other prescribed initial condition. A numerical technique is described later for solving the equations of motion. 


\subsubsection{Aerodynamic Flight Parameter}

It follows from Equation (3) that for a given flow field and initial conditions, the motion of the missile depends only upon the value of the parameter $C_{D} A / W$. Values of $C_{D}$ are determined in wind tunnel tests. The values tend to be a function of Reynolds number, depending on the shape of the missile.

According to Simiu and Cordes (1976), Equation (3) is a reasonable model if, during motion, the missile cither maintains a constant or almost constant attitude rclative to the relative wind velocity vector or has a tumbling motion such that some mean value of $C_{D} A$ can be used with no significant error. Furthermore, for a body to maintain a constant attitude, the resultant aerodynamic force would have to be applied exactly at the center of mass of the body, which is highly unlikely, given the turbulence and wind velocity gradients in a tornado. Since no stabilizing effect is produced by the flow of air past a bluff body, the assumption that tornado missiles tumble during their flight appears to be reasonable. The assumption of a tumbling mode is used in this work.

Simiu and Cordes (1976) accounted for random tumbling by assuming that an equivalent value of the product of $C_{D} A$ is given by the expression as follows:

$$
C_{D} A=c\left(C_{D 1} A_{1}+C_{D 2} A_{2}+C_{D 3} A_{3}\right)
$$

in which $\mathrm{C}_{\mathrm{Di}} \mathrm{A}_{\mathrm{i}}(\mathrm{I}=1,2,3)$ are products of the projected areas corresponding to the principal axes of the body, and the corresponding static drag coefficients. The area A is specified as the largest projected surface area of the missile. In Equation (4), c is a weighting coefficient assumed to be 0.50 for timber planks, rods, pipes and poles. Table 3.1 lists the flight parameters for the $2 \times 4$ timber plank and $3 \mathrm{in}$. dia. steel pipe. 
Table 3.1 Tornado Missile Flight Parameters

\begin{tabular}{|c|c|c|c|c|c|c|c|}
\hline \multirow{2}{*}{$\begin{array}{l}\text { Missile } \\
\text { Type }\end{array}$} & \multirow{2}{*}{$\begin{array}{c}\text { Missile } \\
\text { Dimensions } \\
\text { (in.) }\end{array}$} & \multirow{2}{*}{$\begin{array}{l}\text { Missile } \\
\text { Weight } \\
\text { (Ib./ft) }\end{array}$} & \multicolumn{5}{|c|}{ Drag Coefficients and Areas } \\
\hline & & & $\begin{array}{r}C_{D 1} \\
\left(A_{1}\right) \\
\end{array}$ & $\begin{array}{c}C_{D 2} \\
\left(A_{2}\right) \\
\end{array}$ & $\begin{array}{c}\mathbf{C}_{\mathrm{D3}} \\
\left(\mathbf{A}_{\mathbf{3}}\right) \\
\end{array}$ & $\begin{array}{c}\mathbf{C}_{\mathrm{D}} \mathbf{A}^{*} \\
\left.\text { (ft. }^{2}\right)\end{array}$ & $\begin{array}{c}\mathrm{C}_{\mathrm{D}} \mathrm{A} / \mathrm{W} \\
\left(\mathrm{ft}^{2} / \mathrm{Ib} .\right)\end{array}$ \\
\hline $\begin{array}{c}(2 \times 4) \\
\text { Timber } \\
\text { Plank }\end{array}$ & $\begin{array}{c}15 / 8 \times 35 / 8 \\
\times 144\end{array}$ & 1.25 & $\begin{array}{c}2.00 \\
(1.63)\end{array}$ & $\begin{array}{c}2.00 \\
(1.63)\end{array}$ & $\begin{array}{c}2.00 \\
(0.04)\end{array}$ & 5.29 & 0.352 \\
\hline $\begin{array}{l}\text { 3-in. } \\
\text { dia. } \\
\text { Steel } \\
\text { Pipe }\end{array}$ & $\begin{array}{c}31 / 2 \text {-in. dia. } \\
\text { x } 120\end{array}$ & 7.58 & $\begin{array}{c}0.70 \\
(2.92)\end{array}$ & $\begin{array}{c}2.00 \\
(0.07)\end{array}$ & $\begin{array}{c}0.70 \\
(2.92)\end{array}$ & 2.11 & 0.028 \\
\hline
\end{tabular}

$A$ is the largest projected surface area
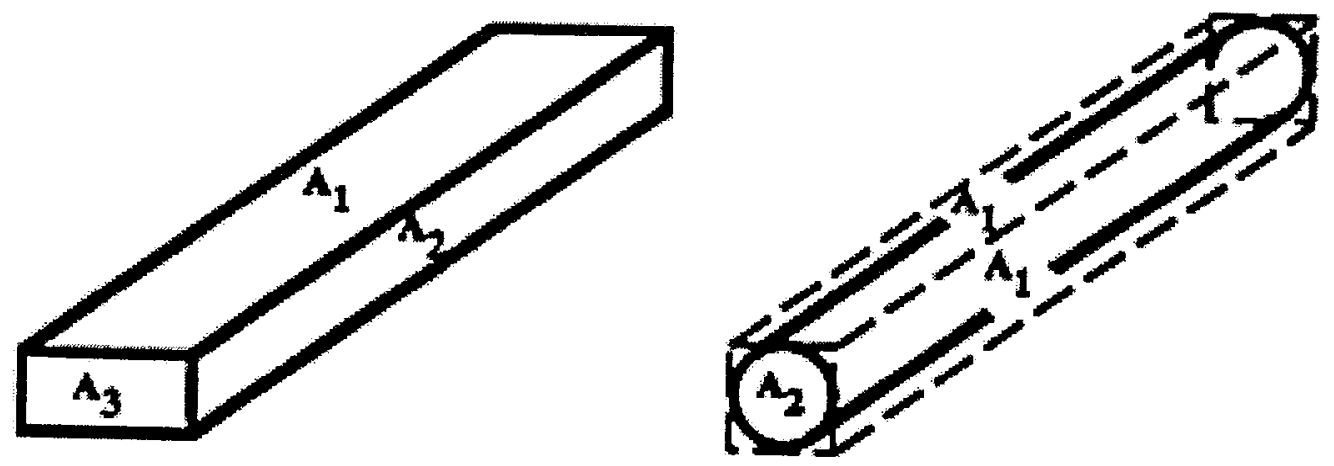

Timber Plank

Steel Pipe 


\subsubsection{Means of Injection}

Bates and Swanson (1967) introduced the idea of three possible ways for a missile to be injected into the tornado wind field as given below:

1. Explosive injection caused be a suddenly-imposed pressure differential,

2. Aerodynamic injection where the shape of an object produces lift in the horizontal air flow while the object is restrained for some brief period of time, and

3. Ramp injection where the object achieves a horizontal speed and then is deflected upward.

These mechanisms have been incorporated in trajectory calculations in various ways. Lee (1973) assumed that missiles are initially lifted off the ground by a vertical lift force caused by both the horizontal and vertical components of the tornado wind. He assumed that the effective lift force only acts for a brief period of time, and thus produces an impulsive force. Although the pipe and plank missiles are not airfoils in the strictest sense, their shapes when combined with random tumbling appear to sustain a limited force produced by the horizontal flow of air. The upward component of the tornado wind alone is not large enough to overcome the pull of gravity and allow light and medium weight missiles to be carried to great heights as observed in available tornado movies. Some lift produced by the horizontal wind component is required for sustained flight.

Most tornado missiles studies simply place the missile at some location in the tornado path and suddenly release it to the wind field. When a missile is released in this fashion, the aerodynamic drag force produces a sudden acceleration and the missile is displaced from its initial position. The problem with this approach is that it does not consider the circumstances under which the missile is released. 
Potential missiles are either attached, loosely attached, or unattached to SSCs. The wind speed at which a missile is released from its attachment is called the missile release wind speed. As a tornado translates along its path, the location of a potential missile experiences wind speed of varying magnitude and direction. When the tornado wind speed reaches the missile release wind speed, the missile is free to be transported by the wind. The direction that the missile will move depends on the direction of the tornado wind speed vector at the instant of release.

The missile release wind speed greatly affects the path taken by the missile and determines if the missile will move at all. If the tornado wind speed is less than the minimum missile release speed, the missile will remain stationary. If the missile releases at a small wind speed, the drag force on the missile will be small and hence the initial acceleration will be small and the missile may not travel very far before failing to the ground. The wind speed at which a missile will release generally can be calculated, if its form of attachment and its material propertics are known.

The wind speeds at which the $2 \times 4$ plank and 3-in. diameter pipe release are estimated at 100 and $150 \mathrm{mph}$, respectively. The timber plank is representative of a class of missiles that result from the destruction of timber residences, trailers or commercial buildings. The wind speed that produces destruction to the extent that individual pieces of timber are released from the roof or wall structures is estimated to be about $100 \mathrm{mph}$ (Minor et al., 1977). The 3-in. diameter pipe is representative of a class of missiles including small pipe columns, electrical conduit, fence posts, and TV antennas. These items are generally more securely attached than the timber missiles. Hence, they have a larger estimated release wind speed than the timber planks. 
The initial height of a missile above ground affects the magnitude of the vertical and horizontal wind component acting on the missile. A plank or pipe missile lying on the ground will not be picked up because the vertical and horizontal wind components approach zero at ground level. Missiles located at some elevation above ground will be picked up and transported by the tornado wind. However, as the initial missile height is decreased, a level is reached where it will not be transported. The vertical and horizontal components of wind are not able to sustain the missile in the wind field. If released, it will fall to the ground. The vertical and horizontal components of the tornado wind increases with the height in the DBT-77 model up to the top of the boundary level (several hundred feet). Thus, the higher the initial missile position, the larger the force trying to lift the missile. In the case of the $2 \times 4$ plank and 3 in. diameter pipe missiles, the source of these missiles is assumed to be buildings from one to three stories high. Their initial heights are likely to range from 12 to $52 \mathrm{ft}$ above ground.

\subsection{Formulation of IDR Tornado Missile Trajectory Code}

A computer program developed at the Institute for Disaster Research (IDR), Texas Tech University (Luan, 1987), calculates the time-history response of missiles generated by an assumed tornado wind field model. The program also predicts values of maximum height achieved by the missiles. Details of the IDR tornado missile trajectory code are described below. 


\subsubsection{Equations of Motion}

The equations of motion used in the code are based on a rectangular coordinate system. The radial, tangential and vertical wind components, $\mathrm{U}, \mathrm{V}, \mathrm{W}$, respectively, are converted to rectangular coordinates by the following transformation equations:

$$
\begin{aligned}
& \mathrm{V}_{\mathrm{x}}=\mathrm{U} \cos \theta-\mathrm{V} \sin \theta \\
& \mathrm{V}_{\mathrm{y}}=\mathrm{U} \sin \theta-\mathrm{V} \cos \theta \\
& \mathrm{V}_{\mathrm{z}}=\mathrm{W}
\end{aligned}
$$

where $V_{x}$ and $V_{y}$ are the horizontal wind speeds in the $x$ and $y$ directions, respectively. $\mathrm{V}_{\mathrm{z}}$ is the vertical wind speed in the $\mathrm{z}$ direction and $\theta$ is the angle that a line joining the tornado center and the missile position makes with the $\mathrm{x}$-axis. The translational velocity of the tornado is added vectorially to the wind velocity components.

Recall from Section 3.5 that the dynamic equation of missilc motion is based on the aerodynamic drag force produced by the wind. Equation (3) is the dynamic missile acceleration equation. Let $\mathrm{P}_{\mathrm{f}}$ represent the aerodynamic flight parameter, $\mathrm{C}_{\mathrm{D}} \mathrm{A} / \mathrm{W}$. Recognizing that

$$
a=\left(a_{x}^{2}+a^{2}{ }_{y}+a^{2}{ }_{z}\right)^{1 / 2}
$$

and

$$
V_{r}=\left(V_{r x}^{2}+V_{r y}^{2}+V_{r z}^{2}\right)^{1 / 2}
$$

the $\mathrm{x}, \mathrm{y}$, and $\mathrm{z}$ components of acceleration can be expressed as follows:

$$
\begin{aligned}
& \mathrm{a}_{\mathrm{x}}=0.5 \gamma \mathrm{P}_{\mathrm{f}} \mathrm{V}_{\mathrm{rx}} \mathrm{V}_{\mathrm{r}} \\
& \mathrm{a}_{\mathrm{y}}=0.5 \gamma \mathrm{P}_{\mathrm{f}} \mathrm{V}_{\mathrm{ry}} \mathrm{V}_{\mathrm{r}} \\
& \mathrm{a}_{\mathrm{z}}=0.5 \gamma \mathrm{P}_{\mathrm{f}} \mathrm{V}_{\mathrm{rz}} \mathrm{V}_{\mathrm{r}}
\end{aligned}
$$

where $V_{r}$ is the wind velocity vector relative to the missile. As such as given below: 


$$
\begin{aligned}
& V_{r x}=V_{x}-V_{m x} \\
& V_{r y}=V_{y}-V_{m y} \\
& V_{r z}=V_{z}-V_{m z}
\end{aligned}
$$

where $V_{r x}, V_{r y}$ and $V_{r z}$ are the components of the relative wind velocity vector and $V_{m x}$, $\mathrm{V}_{\mathrm{my}}$ and $\mathrm{V}_{\mathrm{mz}}$ are the components of the missile velocity vector. In the $\mathrm{z}$ direction, the effect of gravity and lift produced by the horizontal wind component must be taken into account in the acceleration term. Thus, the expression for acceleration in the $\mathrm{z}$ direction is as follows:

$$
\mathrm{a}_{\mathrm{z}}=0.5 \gamma \mathrm{P}_{\mathrm{f}} \mathrm{V}_{\mathrm{rz}} \mathrm{V}_{\mathrm{r}}-\mathrm{g}+0.5 \gamma \mathrm{P}_{\mathrm{fz}} \mathrm{V}_{\mathrm{rz}} \mathrm{V}_{\mathrm{rxy}}^{2}
$$

where $\mathrm{g}$ is gravity acceleration, $32.2 \mathrm{ft} / \mathrm{sec}^{2}$

$$
V_{r x y}^{2}=V_{r x}^{2}-V_{r y}^{2}
$$

\subsubsection{Numerical Solution}

The IDR computer code uses an iterative scheme to numerically solve for the missile propagation along its trajectory. It is assumed that the acceleration over a time step, dt, varies linearly as shown below:

$$
a_{i+1}=K d t+a_{i}
$$

where $\mathrm{dt}$ represents the time interval between steps $\mathrm{i}$ and $\mathrm{i}+1$, and $\mathrm{K}$ is a constant which is initially assumed to be as follows:

$$
K=\left(a_{i}-a_{i-1}\right) / d t
$$

Then, based on this assumption, a new velocity and position of the missile at step i+1 are evaluated by the following equations:

$$
\mathrm{V}_{\mathrm{Mi}+1}=0.5\left(\mathrm{a}_{\mathrm{i}}+\mathrm{a}_{\mathrm{i}+1}\right) \mathrm{dt}+\mathrm{V}_{\mathrm{Mi}}
$$




$$
R_{\mathrm{Mi}+1}=0.5\left(\mathrm{~V}_{\mathrm{i}}+\mathrm{V}_{\mathrm{i}+1}\right) \mathrm{dt}+\mathrm{R}_{\mathrm{Mi}}
$$

where $\mathbf{R}_{M}$ is the position of the missile with respect to the origin of the coordinate axes. Once the new position and velocity of the missile are known, the acceleration of the missile is calculated using Equation (8). Using these new values of the acceleration components, the process is repeated until the accelerations from the previous iteration are within some specified tolerance, e. The above steps are repeated for each time increment dt. The value for $\mathrm{dt}$ is typically $0.1 \mathrm{sec}$.

\subsubsection{Computer Code}

A computer code is used to calculate trajectories and velocities of tornadogenerated missiles. The computer code is written in BASIC language to numerically solve the equations formulated previously in this section. The program calculates the missile position, velocity, and acceleration as a function of time.

The input data required for the program are tornado wind field characteristics, missile flight parameter, and the initial location of the missile. Three tornado parameters are required as input. These are maximum tangential wind speed, radius of maximum wind speed and the translational speed of the tornado. The initial parameters of the missile include the initial coordinates relative to the origin of the coordinate system, and the missile release wind speed.

The tornado starts at the origin of the coordinate system shown in Figure 3.1. The initial position of the missile is specified relative to the coordinate system ( $\mathrm{R}_{\mathrm{mx}}, \mathrm{R}_{\mathrm{my}}$, $R_{m z}$ ). The initial value of $R_{m x}$ is arbitrary. It should be larger than the radius of damaging winds to assure that wind speed is less than release value. The tornado 


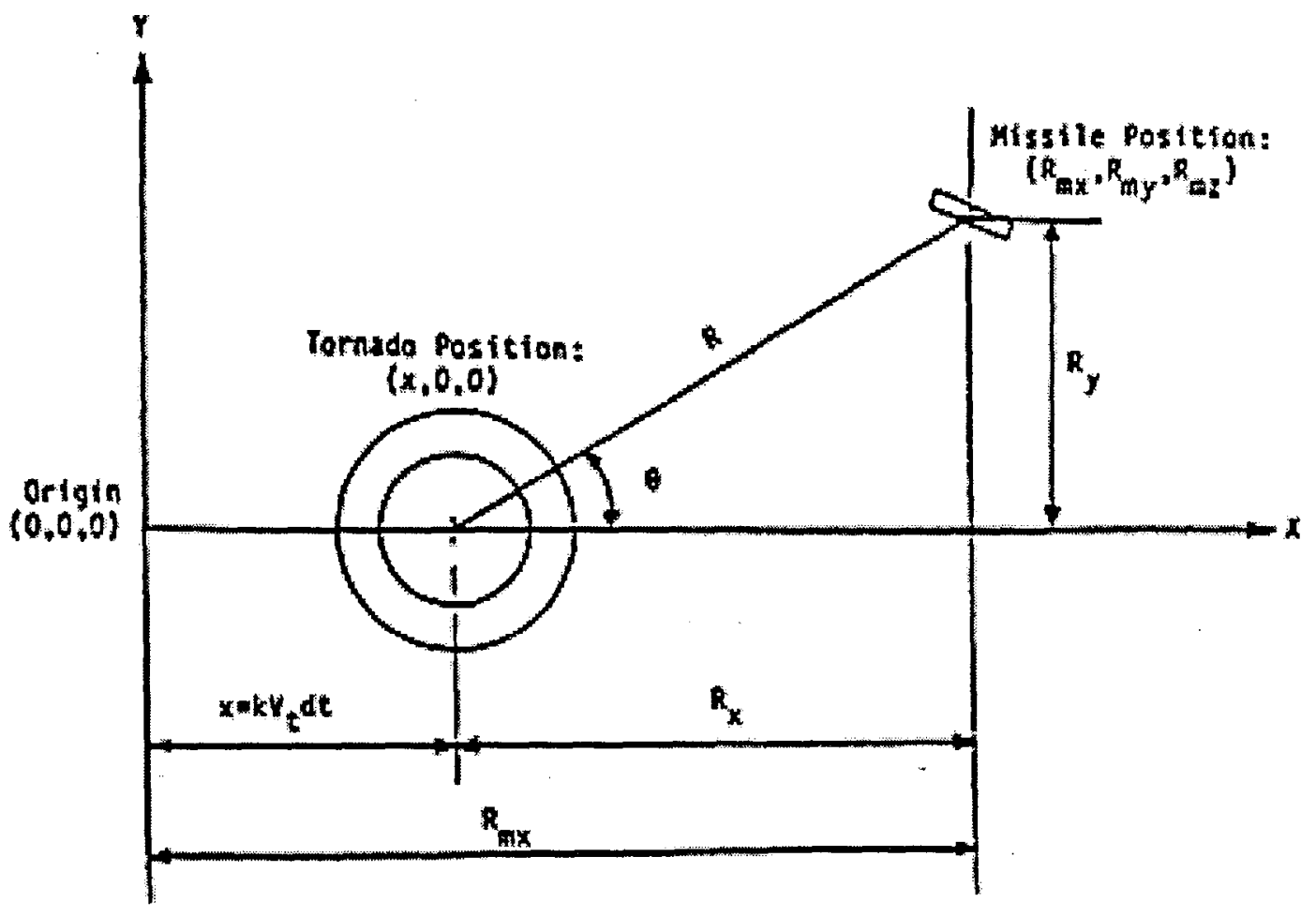

FIGURE 3.1 SPATIAL RELATIONSHIP BETWEEN

TORNADO AND MISSILE 
marches along the $\mathrm{x}$-axis. Its position at any time step is given below:

$$
\mathrm{x}=\mathrm{k} \mathrm{V}_{\mathrm{t}} \mathrm{dt}
$$

where

$k$ is the number of steps from $t$ equals zero,

$V_{t}$ is translational speed of the tornado, $\mathrm{ft} / \mathrm{sec}$, and

$\mathrm{dt}$ is the time step, sec.

The distance from the tornado position to the missile is $\mathbf{R}$ and the angle measured from the tornado path is $\theta$ (see Figure 3.1). The parameters $R$ and $\theta$ determine the magnitude and direction of the wind components acting on the missile. The wind velocity vector at the missile location is obtained from a subroutine called WINDVEL, which models DBT-77. The tornado moves along the $\mathrm{x}$-axes, moving forward with each time step until the horizontal component of wind speed at the missile reaches the missile release speed, at which time the missile is released from its restraint. The tornado continues to move along the $\mathrm{x}$-axis and the missile responds to the tornado winds according to the dynamic equation of motion. The calculations are terminated when the missile strikes the ground. Tornado position, tornado wind speed, missile speed, acceleration and position are recorded at each time step after release. The maximum horizontal speed, maximum vertical speed and maximum height above ground achieved by the missile also are recorded.

\subsection{Validation of IDR Computer Code}

The IDR computer code for tornado missile trajectories has been used since its first development in 1975. Two instances are cited in this section for the purpose of 
validating the code. The first case is an attempt to produce the trajectories of six heavy. weight missiles, whose behavior was observed in the field. The second case is a comparison of results of trajectory calculations with the model published by Simiu and Cordes (1976).

\subsubsection{Bossier City, Louisiana Tornado}

In December 1978 a violent tornado struck Bossier City, Louisiana. Six W14x30 wide-flange steel beams, weighing up to $700 \mathrm{lbs}$ each, were picked up and transported from the roof of Meadowview Elementary school to various locations around the school. One of the six beams impacted the roof of a house located more than $1000 \mathrm{ft}$ from the beam's original location. The others traveled lesser distances and in other directions. The damage at the school was carefully documented by McDonald (1981) and Fujita (1979). From a ground survey, McDonald determined the original location of each beam, its impact point, and the construction details that related to the release wind speed. The Fujita made an aerial survey of the residential damage surrounding the school. From the data collected, Fujita estimated the location of the tornado path center line, as it traveled across the school ground. In addition, he deduced the radius of maximum wind speed and estimated the maximum tangential wind speed and the translational speed of the tornado. Based on other damage to the building, Fujita estimated the maximum wind speed at the school to approximately $200 \mathrm{mph}$. The radius of maximum wind speed was only $50 \mathrm{ft}$, which is an extremely tight tornado core. The tight core contributed to the powerful forces that transported the $700 \mathrm{lb}$ beam sections. The translational speed was estimated at $25 \mathrm{mph}$. 
Maaleb (1980) used the IDR tornado missile trajectory code to try and reproduce the six missile trajectories. The tornado characteristics identified by Fujita were scaled to fit the DBT-77 model. The known quantities for the analyses were tornado wind field characteristics, missile shape and weight, initial location and impact points of the missiles. The unknowns were missile flight parameters and wind speed to release the missiles from their restraints. Reasonable values of both of these parameters could be estimated, but each could vary within a range of values. A number of combinations of the unknown parameters were tried until trajectories were found that began at the original missile locations and terminated in the vicinity of the observed points. Figure 3.2 shows the six trajectories that best matched the initial missile locations and the impact points (Maaleb, 1980). The IDR trajectory code was thus able to reproduce reasonable trajectories using flight parameters and missile release wind speeds that fell within a plausible range. While this is only circumstantial evidence, the results demonstrate the ability of the computer code to predict reasonable trajectories that matched observations in the field. The IDR computer code results also explained why the impact points of the six missiles were dispersed over such a wide area (see Figure 3.2).

In making trajectory calculations, a missile is located at some fixed point, and the tornado is passed along a predetermined path. The missile is restrained by its connections or anchorages until the tornadic wind speed reaches a value to overcome the restraint forces. The trajectory followed by the missile depends on where the missile is located relative to the tornado's location and the value of the wind speed at release. Of major importance is whether the missile is on the right side or the left side of the tornado's center line. Two cases are illustrated using a timber missile. In Figure 3.3, the 


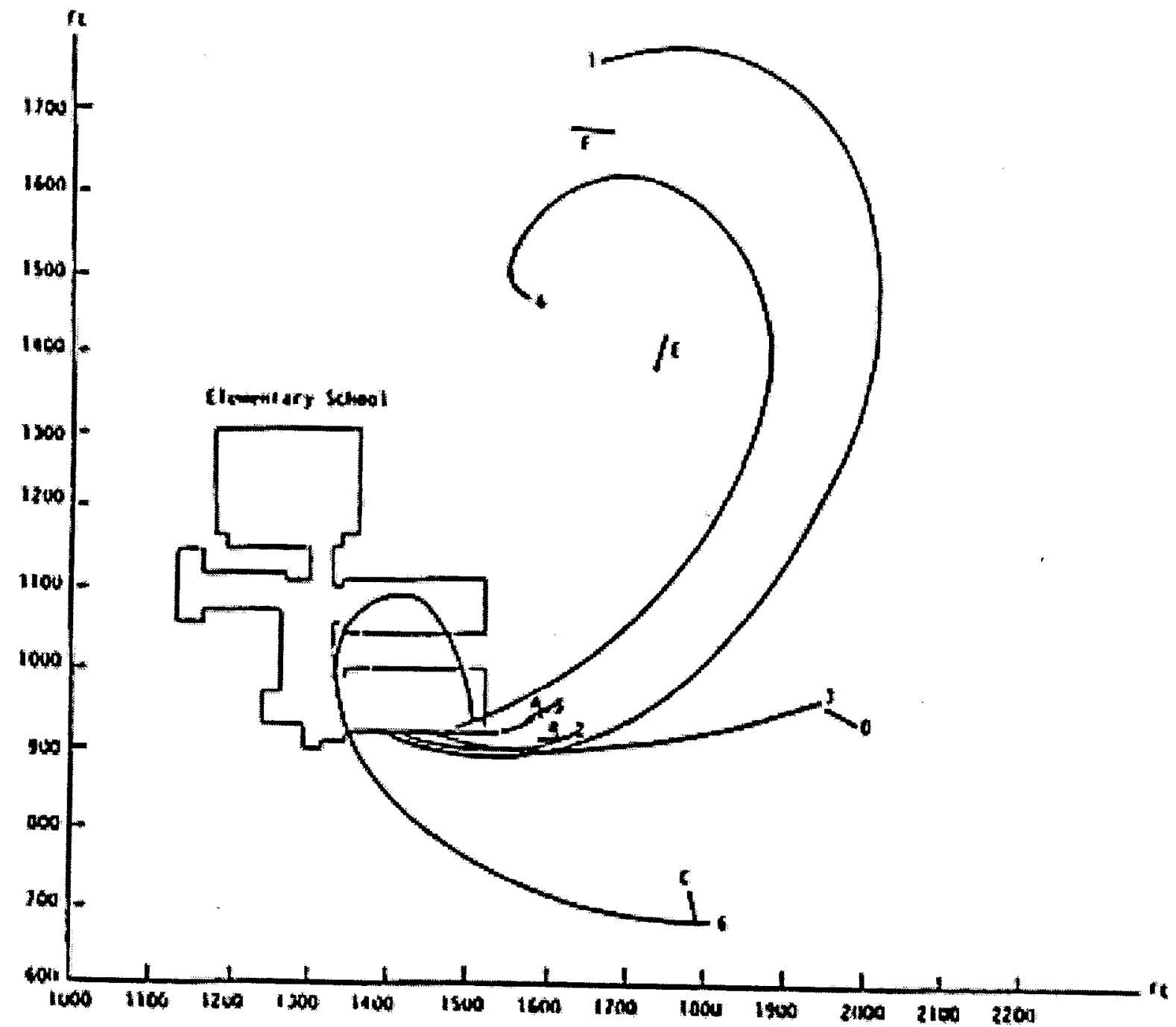

FIGURE 3.2 CALCULATED MISSLE TRAJECTORIES AND OBSERVED IMPACT POINTS (MAALEB, 1980) 
missile is initially located on the left side of the tornado path center line (looking in direction of translation). The missile does not release from its restraint until center of the tornado is past the missile. The trajectory then wraps around the back side of the tornado wind field. It crosses the center line and impacts on the right side of the tornado path. The missile in Figure 3.4 is initially located on the right side of the tornado center line and releases on the front side of the tornado wind field. The missile almost makes a loop. The net distance traveled by the missile from its point of origin to its impact point is small, compared to the first example. However, the distance traveled along the trajectory path is relatively large.

\subsubsection{Comparison with NBS Trajectory Model}

Simiu and Cordes (1976) published a three degree-of-freedom trajectory model (NBS model). Many features of the NBS model are similar to the IDR model, although they were developed independently. The primary differences are in the wind field models and the manner in which the missiles are released from their restraints. The two models essentially use the same dynamic equations, both assume a tumbling mode in evaluating the aerodynamic flight parameters and both use a numerical integration scheme to calculate the trajectories.

The major difference in the two methods is the wind fields. The NBS model uses a wind field that has linear relationship between radial and vertical wind components as a function of tangential wind speed. The tangential wind speed is treated as a Rankine combined vortex model. Table 3.2 Shows a comparison between results of the NBS and IDR trajectory models for the $2 \times 4$ timber plank and 3 -in. diameter steel pipe. When the 


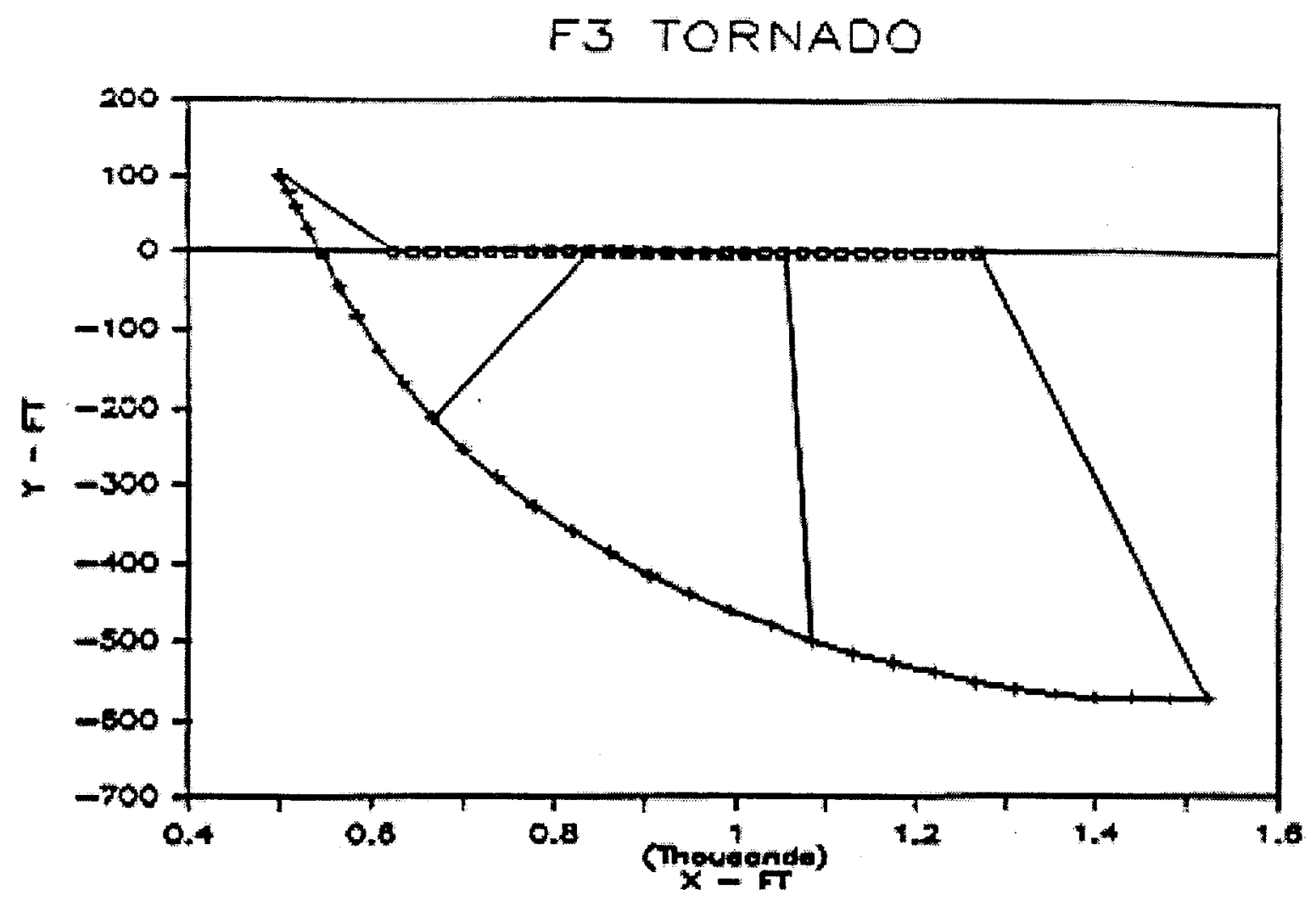

Initial Position of Timber Missile Relative to Tornado path:

$X=500 \mathrm{ft}, \quad Y=100 \mathrm{ft}, \quad Z=12 \mathrm{ft}$ (initial height)

Missile Release Wind Speed: $\quad 100 \mathrm{mph}$

F3 Tornado Parameters:

Maximum Tangential Speed: $148 \mathrm{mph}$

Radius of Maximum Wind: $193 \mathrm{ft}$

Translational Speed: $\quad 50 \mathrm{mph}$

FIGURE 3.3 MISSILE POSITION REALTIVE TO TORNADO POSITION WHEN MISSILE IS RELEASED ON LEFT SIDE OF TORNADO PATH 


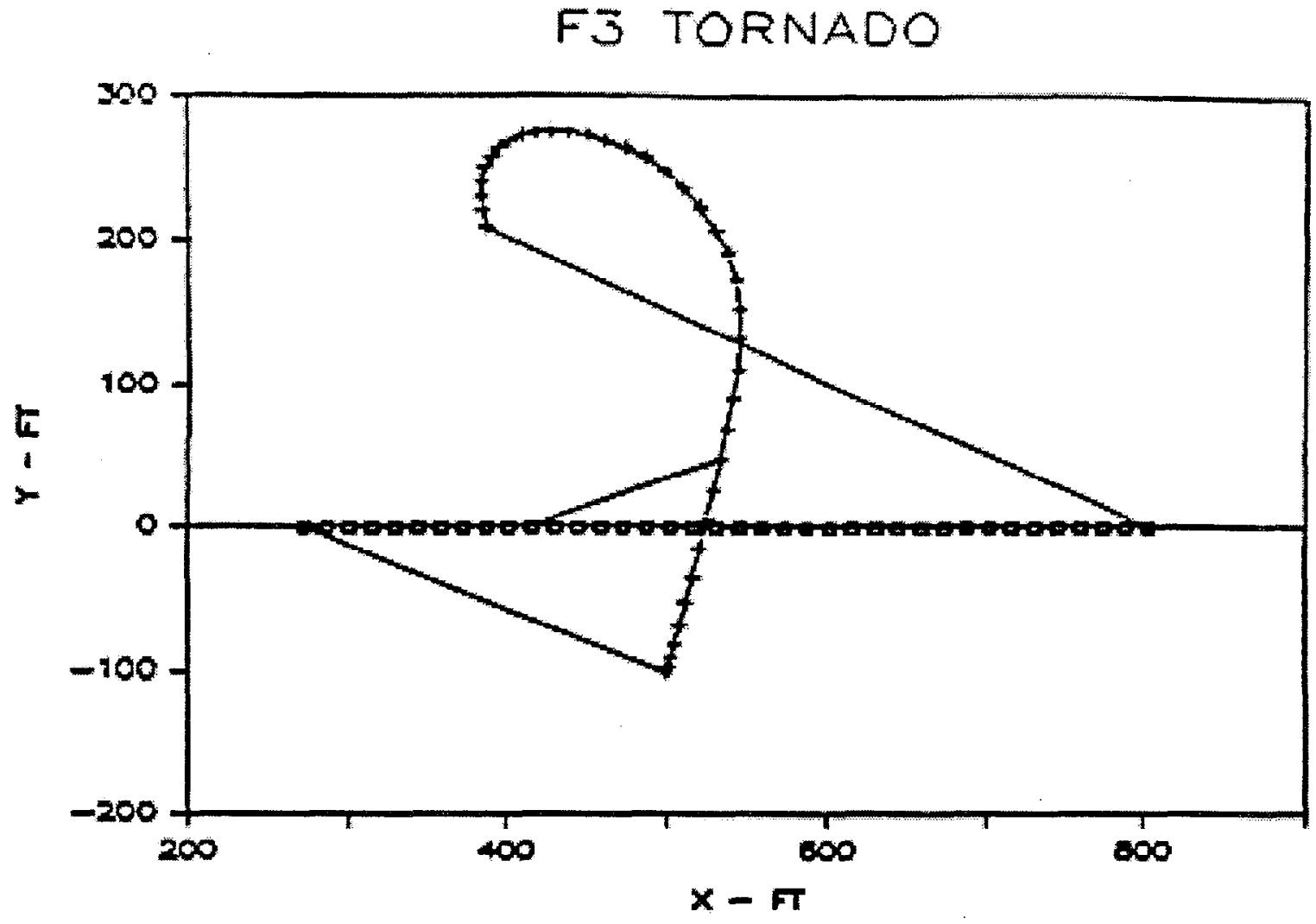

Initial Position of Timber Missile Relative to Tornado path:

$X=500 \mathrm{ft}, \quad Y=-100 \mathrm{ft}, \quad \mathrm{Z}=12 \mathrm{ft}$ (initial height)

Missile Release Wind Speed: $\quad 100 \mathrm{mph}$

F3 Tornado Parameters:

Maximum Tangential Speed: $148 \mathrm{mph}$

Radius of Maximum Wind: $193 \mathrm{ft}$

Translational Speed: $\quad 50 \mathrm{mph}$

FIGURE 3.4 MISSILE POSITION REALTIVE TO TORNADO POSITION WHEN MISSILE IS RELEASED ON RIGHT SIDE OF TORNADO PATH 
NBS wind field is used in the IDR model, the maximum horizontal missile speeds are almost identical. This comparison is presented as quality assurance for the IDR model. When the DBT- 77 wind field is used in the IDR trajectory model, the maximum horizontal missile speeds are on the average 50 percent less than those predicted by the NBS model (see Table 3.2). The reason for the difference is that the DBT-77 tornado wind field only has a strong updraft (vertical wind speed) in the outer core, which extends over a limited area. The NBS tornado wind field model has a strong updraft over the entire tornado vortex diameter. As discussed in Section 1, there are good reasons to believe that DBT-77 is a valid representation of actual tornado wind flow. When used with the DBT-77 wind field, the IDR trajectory model produces estimates of missile speeds that are consistent with observations in the field. The estimated speeds were indirectly verified by Malaeb's work and agree with an independent model (NBS model) when a direct comparison is made.

\subsection{Estimates of Missile Impact Speeds from Trajectory Simulations}

The exercise for determining expected missile speeds in a tornado of specified Fujita Scale is described in this section. Specific missiles considered are the $2 \times 4$-timber plank and the 3-in. diameter steel pipe, although the method is applicable to any object that can be modeled as a three degree-of-freedom missile. The IDR missile code is used in the trajectory simulations.

\subsubsection{Description of Method}

Missiles (e.g. the $2 \times 4$ plank) are assumed to be uniformly placed across the tornado path and are available to be transported by the tornado winds. A tornado model 
Table 3.2 Comparison of Maximum Horizontal Missile Speeds from NBS and IDR Models

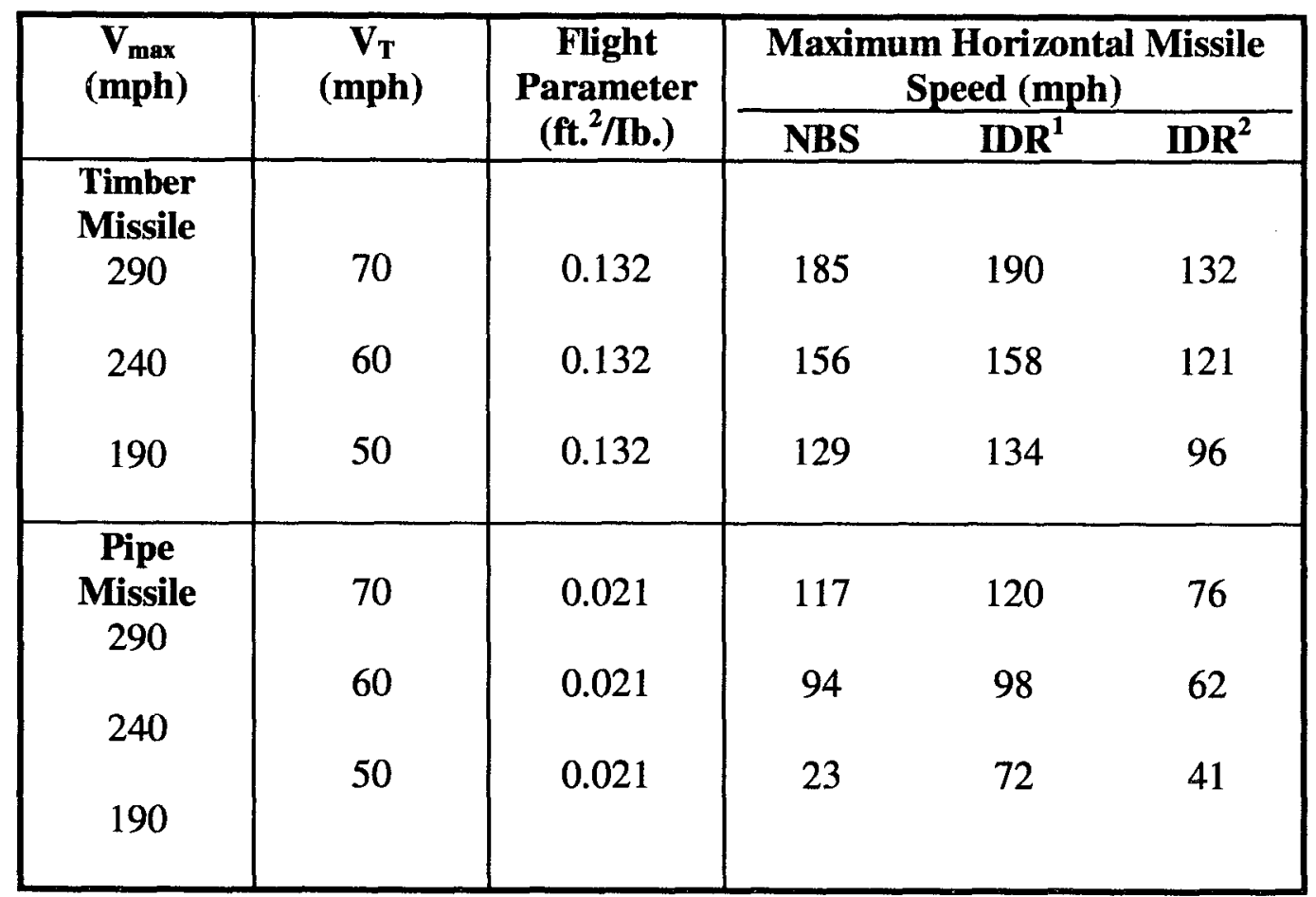

${ }^{2}$ Based on NBS wind field model

${ }^{2}$ Based on DBT-77 wind field model

Notes:

Missile initial position relative to tornado path:

$X=300 \mathrm{ft}, \quad Y=0, Z=130 \mathrm{ft}$ (initial height)

Tornado parameters:

$\mathrm{V}_{\max }:$ Maximum wind speed

VT: Translational wind speed

Radius of Maximum Wind: $150 \mathrm{ft}$. 
(DBT-77) of specified Fujita-Scale intensity is passed over the distributed missiles. The trajectory of each missile is calculated using the IDR missile simulation code. The maximum horizontal and vertical speeds of each missile are tabulated, along with the maximum height each missile achieves. Initial parameters of height above ground, position relative to tornado path and release wind speed are specified for each missile. Each of these parameters has an effect on the missile trajectory, the speed achieved and the height attained by the missile. Specifying the Fujita Scale, $F_{i}$, determines the maximum wind speed and the translational speed of the tornado. Other wind velocity components are then obtained from the DBT-77 tornado wind field model.

All missiles do not release from their restraint, because in some parts of the tornado wind field the wind speed is less than the missile release wind speed. Trajectory calculations are performed for those missiles that are released. Parameters of interest from the trajectory calculations include maximum vertical missile speed and the maximum height achieved by the missile.

Certain parameters that define the tornado wind field and the missile characteristics are not uniquely defined, but vary over a range of values. The initial height of $2 \times 4$ timber plank and 3 in. diameter pipe missiles typically varies from 12 to 50 $\mathrm{ft}$ above ground, if the source of the missiles is destruction of one-to three-story buildings or residences. The maximum tornado wind speed in each Fujita Scale category varies over a range. Likewise, the translational speed ranges typically from 20 to $50 \mathrm{mph}$. These variations are treated in the trajectory calculations. Specific details of the calculations are presented in subsequent sections. 


\subsubsection{Distribution of Missiles}

The number of missiles distributed across the tornado path depends on the path width. The edge of the path is defined by the boundary of $75 \mathrm{mph}$ wind speeds. Because the translational velocity acts in the opposite sense of the tangential velocity on the left side of the path, separate expressions are required for wind speed on the left and right sides of the path. The variation of wind speed across the path width is illustrated in Figure 3.5. The distances from the center of the tornado to the left and right edge (75 mph wind speed), respectively, are:

$$
\mathrm{R}_{\mathrm{L}}=\mathrm{V}_{\mathrm{Lmax}} \mathrm{R}_{\max } / 75
$$

and

$$
\mathrm{R}_{\mathrm{R}}=\mathrm{V}_{\mathrm{R} \max } \mathrm{R}_{\max } / 75
$$

The damage path width is:

$$
\begin{aligned}
\mathrm{W} & =\mathrm{R}_{\mathrm{L}}+\mathrm{R}_{\mathrm{R}} \\
& =\left(\mathrm{R}_{\max } / 75\right)\left(\mathrm{V}_{\mathrm{Lmax}_{\max }}+\mathrm{V}_{\mathrm{R}_{\max }}\right)
\end{aligned}
$$

where

$\mathrm{R}_{\max }$ is the radius of maximum tangential wind speed, $\mathrm{ft}$

$\mathrm{V}_{\mathrm{Lmax}}, \mathrm{V}_{\mathrm{R} \max }$ are maximum wind speeds on the left and right side of the tornado path,respectively, mph

The difference between $V_{\text {rmax }}$ and $V_{\text {Imax }}$ is the translational speed, $V_{t}$.

The missiles are arbitrarily spaced $10 \mathrm{ft}$ apart across the tornado path as illustrated in Figure 3.5. A 10-ft spacing was selected to give a sufficiently large sample for the statistical calculations without requiring an excessive number of trajectory calculations. If the wind to cause the missiles to release from their restraint is greater than $75 \mathrm{mph}$, 


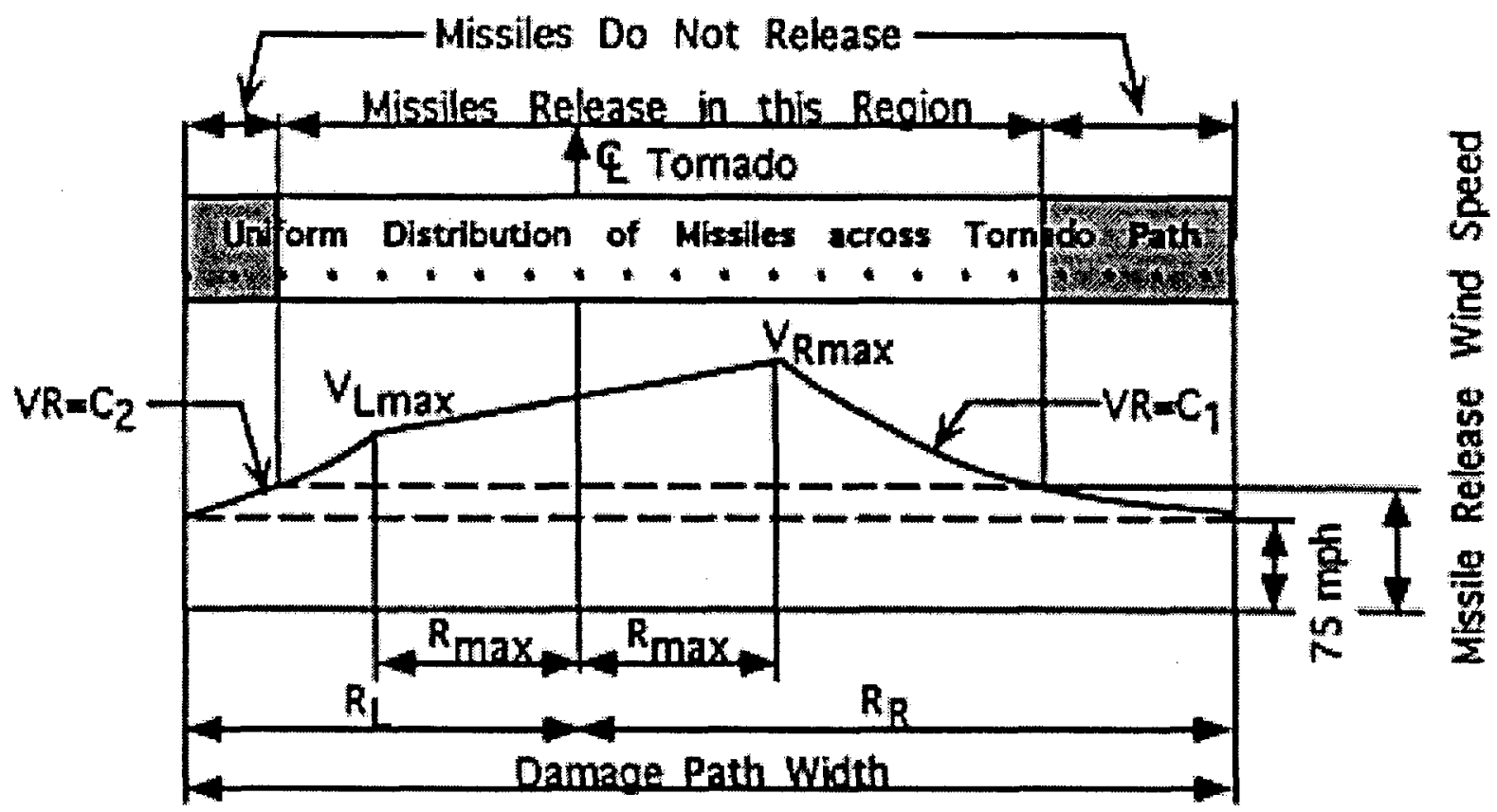

FIGURE 3.5 VARIATION OF WIND SPEED ACROSS TORNADO PATH. MISSLES RELEASE AT WIND SPEEDS GREATER THAN MISSILE RELEASE WIND SPEED 
there will be a strip along each side of the path where missiles are not released (see Fig, 3.5). Table 3.3 lists the number of missiles distributed across the path of each Fujita Scale tornado.

\subsubsection{Sample Trajectory Calculations}

Flight trajectories and the conditional probability distributions are presented in this section for the $2 \times 4$-timber plank in an F3 tornado and the 3 -in. diameter pipe in an F5 tornado. Final results consider both missiles in F2 through F5 tornadoes.

\section{$2 x 4$ Timber Plank}

A study is first performed to identify critical values of initial height and tornado translational speed. Table 3.4 summarizes the results of the study to determine the effect of initial height on the maximum horizontal and vertical missile speeds achieved. Sets of trajectory calculations were run with the initial missile height at 12 and $50 \mathrm{ft}$ above ground. Translatioanal velocity and missile release wind speed were 50 and $100 \mathrm{mph}$, respectively. Missiles released at locations between $420 \mathrm{ft}$ on the left to $980 \mathrm{ft}$ on the right side of the F3 tornado path. The results for missiles located $420 \mathrm{ft}$ on the right side of the path center are listed in Table 3.4. Speeds achieved by the remaining missiles on the right side are not significant. The table shows that missiles released at $12 \mathrm{ft}$ achieve a higher maximum horizontal speed than those that are released at $50 \mathrm{ft}$ above ground. At first glance, this may appear to be an anomaly, because wind speeds in tornadoes tend to increase with height. However, to understand the situation, one must remember that the tornado approaches the missile and the missile releases from its restraint when the wind 
Table 3.3 Number of Missiles Distributed across Path of Each F-Scale Tornado

\begin{tabular}{|c|c|c|c|c|}
\hline $\begin{array}{c}\text { Tornado } \\
\text { F-Scale }\end{array}$ & $\begin{array}{c}\text { Mean Wind } \\
\text { Speed }^{*} \\
\text { (mph) }\end{array}$ & $\begin{array}{c}\text { Radius of } \\
\text { Maximum } \\
\text { Wind Speed } \\
\text { (ft.) }\end{array}$ & $\begin{array}{c}\text { Damage Path } \\
\text { Width } \\
\text { (ft.) }\end{array}$ & $\begin{array}{c}\text { Number of } \\
\text { Distributed } \\
\text { Missiles }^{\star \star}\end{array}$ \\
\hline F2 & 135 & 298 & 940 & 95 \\
F3 & 182 & 416 & 1760 & 177 \\
F4 & 234 & 548 & 2970 & 298 \\
F5 & 290 & 690 & 4620 & 463 \\
\hline
\end{tabular}

${ }_{* *}^{*}$ See Appendix C for details of the F-Scale tornadoes as modeled by DBT-77

${ }^{* *}$ Missiles are uniformly spaced $10 \mathrm{ft}$ apart across damage path 
speed reaches $100 \mathrm{mph}$. Because the wind speed is higher at $50 \mathrm{ft}$ than at $12 \mathrm{ft}$ above ground, the missile at $50 \mathrm{ft}$ releases at a larger distance from the tornado center than the one at $12 \mathrm{ft}$. Because the wind speeds tend to increase with distance from center up to the radius of maximum wind speed, the missile at $12 \mathrm{ft}$ height is initially affected by a higher wind speed gradient than the one at $50 \mathrm{ft}$ and, hence, achieves a higher horizontal speed along its trajectory.

To further illustrate the effect of initial height on maximum horizontal speed achieved by a missile, trajectory calculations were made for missiles located $420 \mathrm{ft}$ left of the tornado center and placed at 12, 20,30,40 and $50 \mathrm{ft}$ above ground. As noted previously, the highest maximum horizontal speed was reached when the missile was released at $12 \mathrm{ft}$ (see Table 3.4). The maximum speed reached by a missile was not significantly affected by initial height. The maximum height reached by a missile was not significantly affected by initial height of the missile. Trajectory calculations that allow the translational speed of the tornado to vary from 20 to $50 \mathrm{mph}$ revealed that the $50 \mathrm{mph}$ translational speed produces highest missile speeds.

These parameters are then used in the set of trajectory calculations that form the basis for the statistical analyses. A summary of the calculation results is given in Appendix A. Figure 3.6 shows a typical plot of horizontal and vertical missile speed and the height of the missile speed and height of the $2 \times 4$ timber as a function of time. Time equals zero at the instant a missile is released. The missile tends to reach its maximum horizontal speed at about the time it reaches maximum height. A positive value of vertical speed means an upward velocity component. 
Table 3.4 Results of Trajectory Calculations (2"x4" Timber Plank in F3 Tornado)

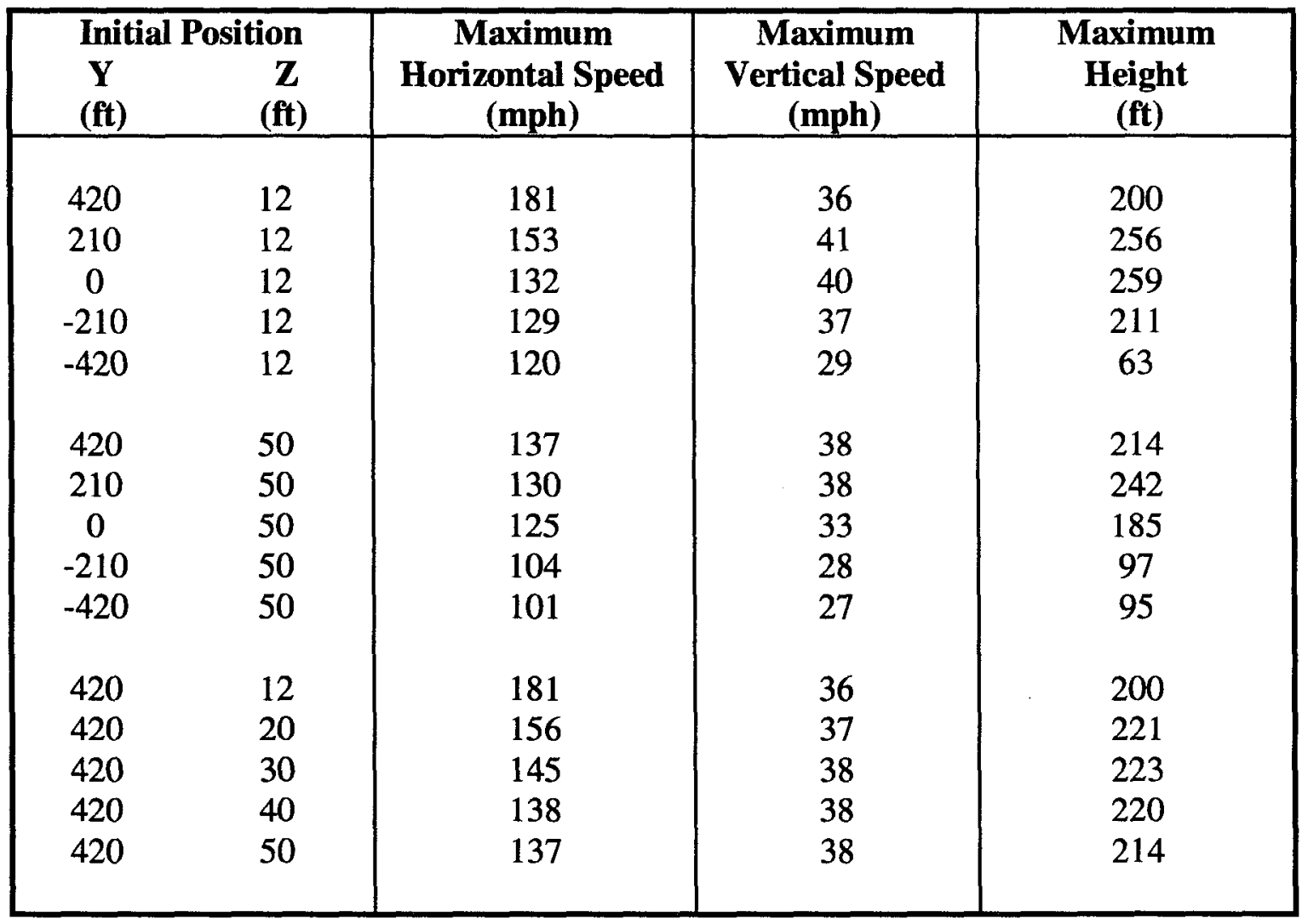

Missile Release Wind Speed: $100 \mathrm{mph}$

Translational Speed: $50 \mathrm{mph}$ 


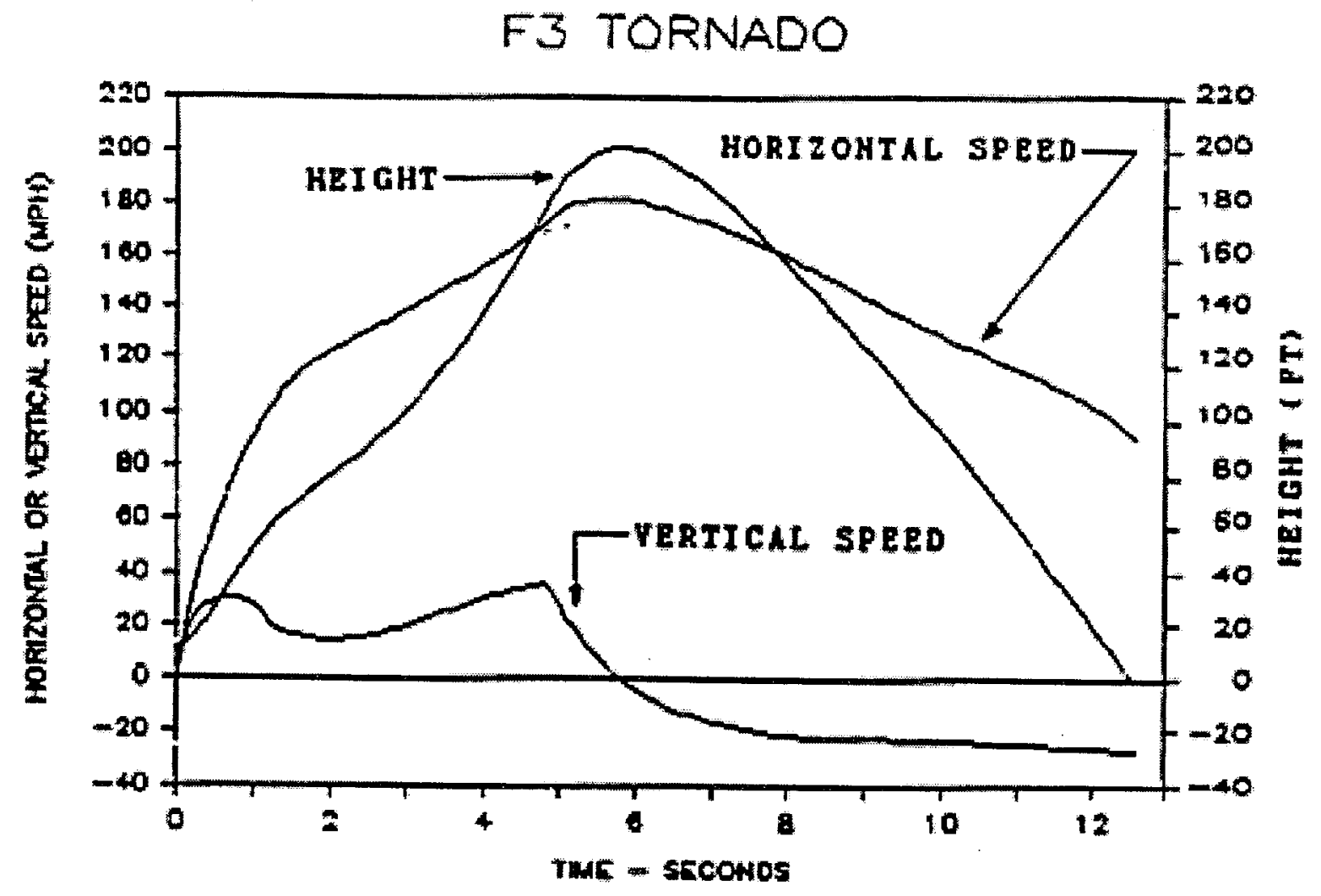

FIGURE 3.6 HORIZONTAL AND VERTICAL MISSILE SPEEDS AND HEIGHT VERSUS TIME FOR 2X4 TIMBER MISSILE 
The horizontal trajectories of five missiles at various locations across the path are shown in Figure 3.7. The timber plank missiles tend to follow the tangential winds around the center of the tornado. Missiles that originate on the left side of the path end up on the right side. Those initially located on the right side of the path do not travel as far as the ones on the left side.

A total of 141 out of 177 missiles were released in the tornado winds. A release frequency histogram of the maximum horizontal $2 \times 4$ timber missile speeds is shown in Table 3.5. Of the missiles that released (at $100 \mathrm{mph}$ wind speed), all of them achieved a speed in the range between $102 \mathrm{mph}$ and $181 \mathrm{mph}$.

From Appendix A, the mean impact speed for the $141,2 \times 4$ timber missile that released in an F3 tornado was $129 \mathrm{mph}$ with a standard deviation of $18 \mathrm{mph}$. From Table 3.5, 77 percent of the released missiles achieved a maximum horizontal impact speed less than $140 \mathrm{mph}$. One of the 141 missile achieved a maximum impact of $181 \mathrm{mph}$ (Trajectory No. 1 in Appendix A). The missile reached a maximum height of $200 \mathrm{ft}$ above ground after being released $12 \mathrm{ft}$ above ground level. The maximum vertical speed of $36 \mathrm{mph}$ was achieved at impact with the ground. Another missile (Trajectory, No. 35 in Appendix A) achieved a maximum height of $275 \mathrm{ft}$ above ground and reached a vertical impact speed of $44 \mathrm{mph}$ at impact with the ground. 


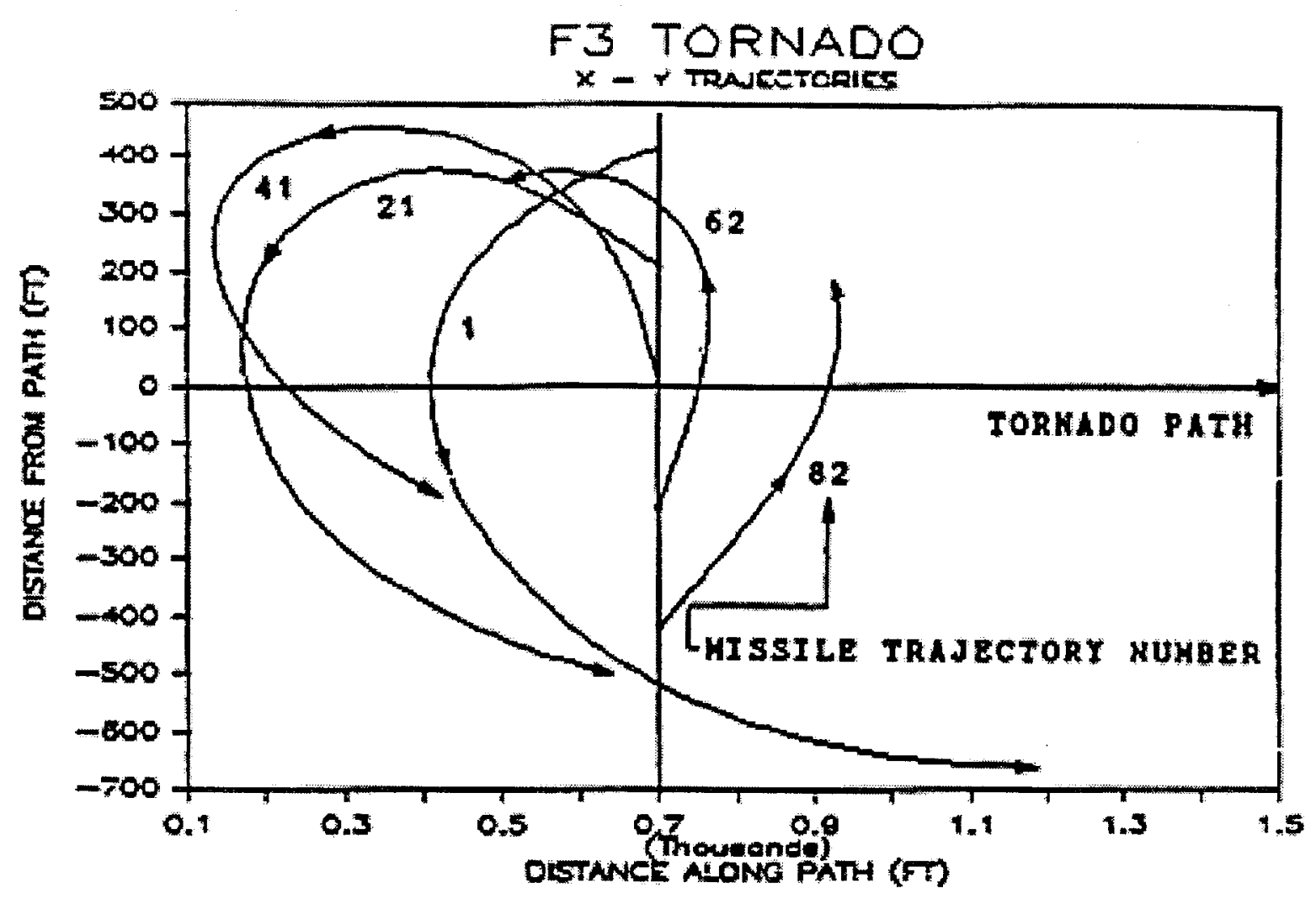

FIGURE 3.7 TYPICAL TRAJECTORIES OF 2X4 TIMBER MISSILES

LOCATED AT VARIOUS DISTANCES FROM F3 TORNADO

PATH CENTERLINE 
Table 3.5 Frequency Histogram of $2 \times 4(15 \mathrm{lb})$ Timber Missile That Released in F3 Tornado

\begin{tabular}{|c|c|c|c|}
\hline $\begin{array}{c}\text { Missile } \\
\text { Speed } \\
(\mathrm{mph})\end{array}$ & $\begin{array}{c}\text { No. of Missiles } \\
\text { Released }\end{array}$ & $\begin{array}{c}\text { Percent } \\
\text { released } \\
(\%)\end{array}$ & $\begin{array}{c}\text { Cumulative } \\
\text { Percent (\%) }\end{array}$ \\
\hline $100-109$ & 21 & 15 & 15 \\
\hline $110-119$ & 34 & 24 & 39 \\
\hline $120-129$ & 23 & 16 & 55 \\
\hline $130-139$ & 31 & 22 & 77 \\
\hline $140-149$ & 9 & 6 & 83 \\
\hline $150-159$ & 12 & 9 & 92 \\
\hline $160-169$ & 7 & 5 & 97 \\
\hline $170-179$ & 3 & 2 & 99 \\
\hline $180-189$ & 1 & 1 & 1.0 \\
\hline Total & 141 & 1.0 & \\
\hline
\end{tabular}

$\mathrm{u}=129 \mathrm{mph}$

$\mathrm{s}=18 \mathrm{mph}$ 


\section{3-Inch Diameter Steel Pipe}

As a second example, calculations are presented for the 3-in. diameter steel pipe missile in an F5 tornado. The procedure is exactly the same as for the $2 \times 4$ timber plank. Table 3.6 summarizes the results of the study to determine the effect of initial height on maximum horizontal and vertical missile speed achieved by the pipe. Again, a set of missile trajectory calculations were run with the initial missile height at 12 and $50 \mathrm{ft}$ above ground. Translational speed of the tornado and missile release wind speed were 50 and $150 \mathrm{mph}$, respectively. Missiles released at locations between $920 \mathrm{ft}$ on the left side to $1630 \mathrm{ft}$ on the right side of F5 the path. Results for missiles located $690 \mathrm{ft}$ on either side of the tornado path are listed in Table 3.6. Speeds achieved by the remaining missiles that released are not significant.

In the case of the pipe, those missiles that released at $50 \mathrm{ft}$ above ground achieved higher speeds than those released at $12 \mathrm{ft}$. The reason is that the pipe basically falls to the ground without experiencing very much lift. Falling from $50 \mathrm{ft}$ rather than $12 \mathrm{ft}$ gives the horizontal components of the wind more time to act on the pipe and accelerate to a higher speed. At $12 \mathrm{ft}$ initial height, neither the horizontal nor vertical speed has time to develop.

The largest horizontal missile speed in Table 3.6 is developed by the missile located $690 \mathrm{ft}$ left of the tornado path center line at an initial height of $50 \mathrm{ft}$. The lower part of Table 3.6 illustrates the effect of increasing the initial height from 12 to $50 \mathrm{ft}$. Both horizontal and vertical missile speeds increase with increasing initial height. 
The maximum vertical missile speeds of the pipes are more sensitive to initial height than those of the $2 \times 4$ plank. The 50 -mph tornado translational speed produces higher missile speeds than those at lower values. These parameters are used in the set of trajectory calculations that form the basis for the statistical analyses. A summary of the pipe missile calculations are given in Appendix B.

Figure 3.8 shows a typical plot of horizontal and vertical missile speed and height of the 3-in. dia. pipe missile as a function of time after release. A comparison of Figures 3.7 and 3.8 clearly shows the difference between the trajectories of the $2 \times 4$ plank and the 3-in. dia. pipe missiles.

The horizontal trajectories of five pipe missiles distributed across the path are shown in Figure 3.9. Missile on the left side of the path tend to move in the opposite direction of the tornado travel. The ones on the right side of the path tend to move across the path and slightly forward.

A total of 256 out of 463 missiles were released in the tornado winds. A release frequency histogram of the maximum horizontal pipe missile speeds is shown in Table 3.7. Of the missiles released (at $150 \mathrm{mph}$ wind speed), the maximum horizontal speeds ranged from 65 to $87 \mathrm{mph}$

From Appendix B, the mean impact speed for the 256 pipe missile that released in an F5 tornado was $78 \mathrm{mph}$ with a standard deviation of $6 \mathrm{mph}$. From Table 3.7, 48 percent of the released pipe missile achieved a maximum horizontal speed greater than or equal to $80 \mathrm{mph}$. The fastest of the 256 missiles that released, reached a top speed of 87 mph (Trajectory, No. 140, Appendix B). The high missile speeds are attributed to the $150 \mathrm{mph}$ release speed. The resulting wind forces suddenly applied to the missile at 


\section{F5 TORNADO}

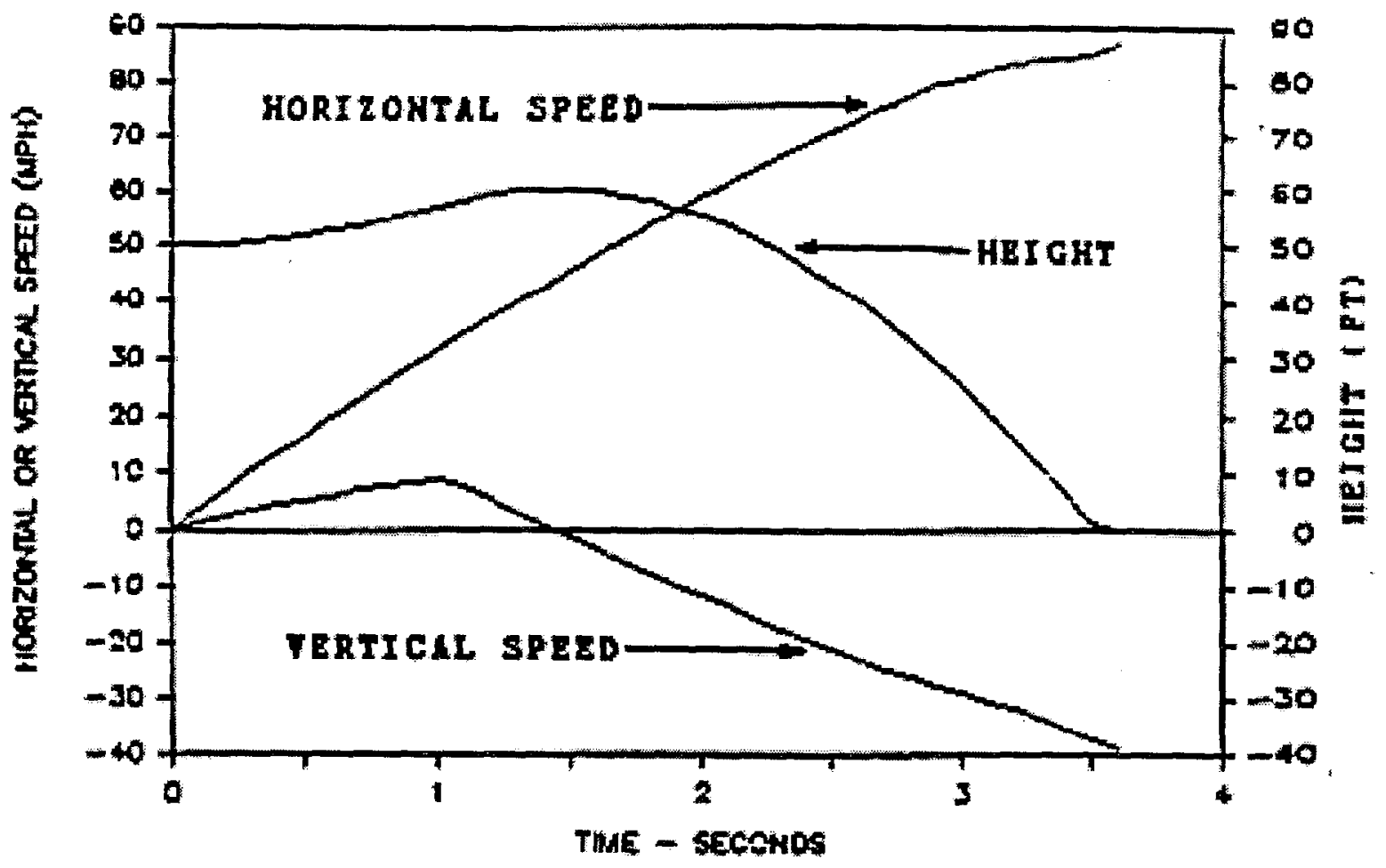

FIGURE 3.8 HORIZONTAL AND VERTICAL MISSILE SPEEDS AND

HEIGHT VERSUS TIME FOR 3-in. dia. STEEL PIPE MISSILE 


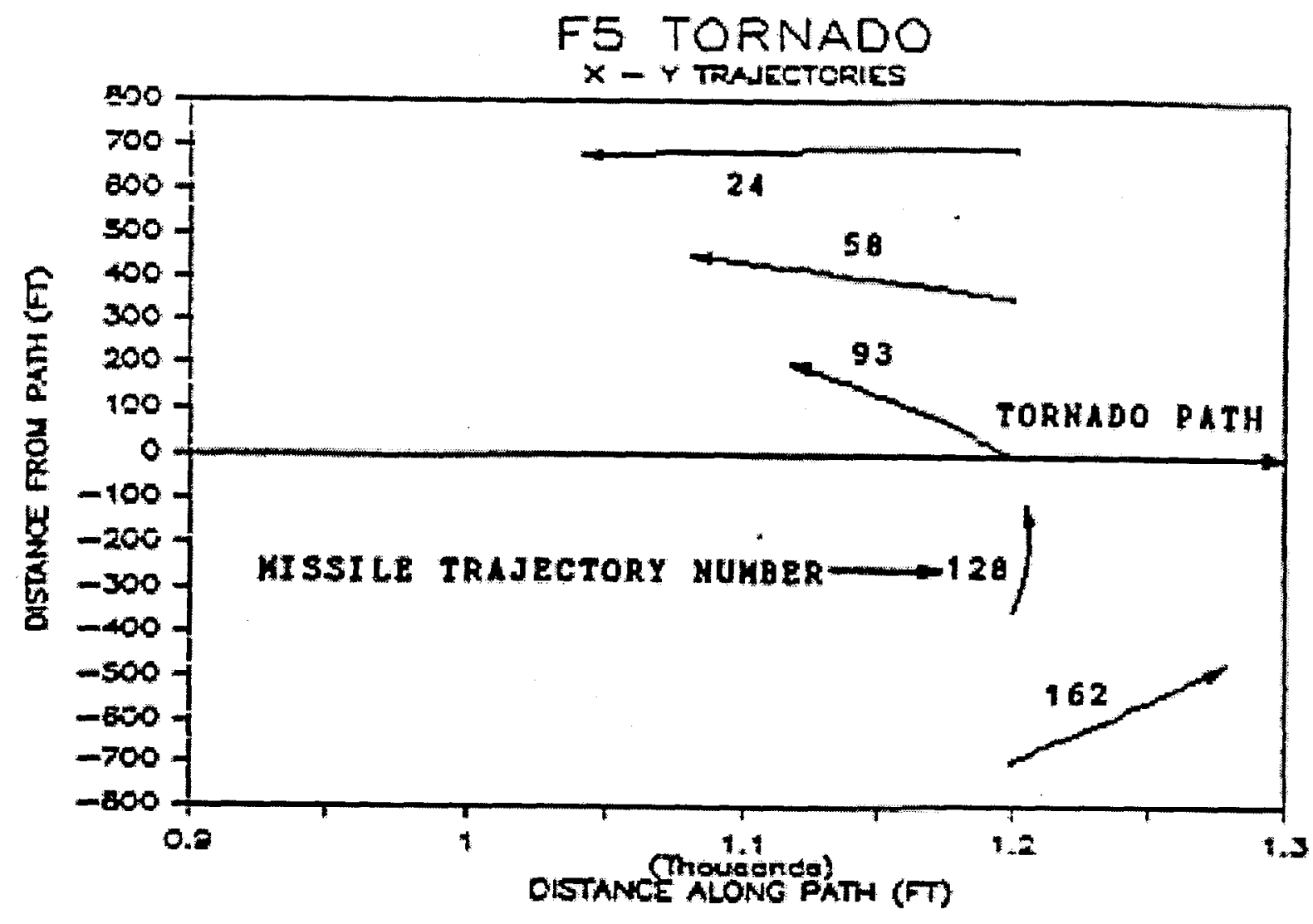

FIGURE 3.9 TYPICAL TRAJECTORIES OF 3-in. dia. STEEL PIPE MISSILES LOCATED AT VARIOUS DISTANCES FROM F5 TORNADO PATH CENTERLINE 
release results in a very rapid acceleration. The pipe missiles typically were lifted from 8 to $11 \mathrm{ft}$ above their release elevation. Upon falling to the ground they reached a maximum vertical speed of $40 \mathrm{mph}$ at impact with the ground.

Table 3.6 Results of Trajectory Calculations for 3 in. dia. Steel Pipe in $F 5$ Tornado

\begin{tabular}{|cc|c|c|c|}
\hline $\begin{array}{c}\text { Initial Position } \\
\mathbf{Y} \\
(\mathbf{f t})\end{array}$ & $\begin{array}{c}\mathbf{Z} \\
(\mathbf{f t})\end{array}$ & $\begin{array}{c}\text { Maximum } \\
\text { Horizontal Speed } \\
(\mathbf{m} \mathbf{p h})\end{array}$ & $\begin{array}{c}\text { Maximum } \\
\text { Vertical Speed } \\
(\mathbf{m p h})\end{array}$ & $\begin{array}{c}\text { Maximum } \\
\text { Height } \\
(\mathbf{f t})\end{array}$ \\
\hline 690 & 12 & & & \\
350 & 12 & 71 & 26 & 24 \\
0 & 12 & 69 & 27 & 26 \\
-350 & 12 & 70 & 26 & 23 \\
-690 & 12 & 68 & 27 & 25 \\
& & 67 & 25 & 23 \\
690 & 50 & 87 & 39 & 60 \\
350 & 50 & 84 & 38 & 61 \\
0 & 50 & 85 & 40 & 60 \\
-350 & 50 & 80 & 39 & 60 \\
-690 & 50 & 75 & 40 & 59 \\
& & & & 24 \\
690 & 12 & 71 & 26 & 31 \\
690 & 20 & 73 & 29 & 41 \\
690 & 30 & 77 & 32 & 50 \\
690 & 40 & 81 & 35 & 60 \\
690 & 50 & 87 & 39 & \\
\hline
\end{tabular}

Missile Release Wind Speed: $150 \mathrm{mph}$

Translational Speed: $50 \mathrm{mph}$ 
Table 3.7 Frequency Histogram of 3-in. Diameter Steel Pipe Missile that released in an F5 Tornado

\begin{tabular}{|c|c|c|c|}
\hline Missile Speed (mph) & $\begin{array}{l}\text { No. of Missiles } \\
\text { Released }\end{array}$ & $\begin{array}{l}\text { Percent } \\
\text { Released (\%) }\end{array}$ & $\begin{array}{l}\text { Cumulative Percent } \\
\text { Released (\%) }\end{array}$ \\
\hline $65-69$ & 35 & 14 & 14 \\
\hline $70-74$ & 54 & 21 & 35 \\
\hline $75-79$ & 44 & 17 & 56 \\
\hline $80-84$ & 86 & 34 & 1.0 \\
\hline $85-89$ & 37 & 14 & \\
\hline Total & 256 & & \\
\hline
\end{tabular}

\subsubsection{Rational for Impact Speed Recommendations}

The probability of the $2 \times 4$ timber missile achieving an impact speed of $181 \mathrm{mph}$ in an F3 tornado is very small. Factors affecting the probability of a missile achieving some threshold impact speed are given below:

1. Probability of wind speed to release and accelerate the missile,

2. Probability that missile will release, and

3. Probability that a missile is at some critical location to be released and accelerated.

Because of these reasons, it is entirely too conservative to select the maximum possible impact speed for design purposes.

Missile barriers are discussed in detail in Chapter 4. The Minimum wall configuration to stop a $15 \mathrm{lb} 2 \times 4$ timber missile is an 8 -in. CMU wall with \#4 rebar grouted in each vertical cell. This wall will stop the missile at any impact speed, large or small. At impact specds below about $135 \mathrm{mph}$, the wall stops the missile with no damage 
to the wall and minimum damage to the missile. At impact speeds greater than $135 \mathrm{mph}$, the wall is not damaged, but missile splinters into many small pieces. Thus, the same minimum wall configuration is adequate for all predicted impact speeds of the $2 \times 4$ timber missiles. The recommended missile criteria for both PC3 and PC4 SSCs is $2 \times 4$ timber missile (15 lb.) at $100 \mathrm{mph}$ impact speeds at any height up to $200 \mathrm{ft}$ above ground.

The probability of the 3-in. diameter steel pipe missile achieving an impact speed of $87 \mathrm{mph}$ in an F5 tornado is significantly smaller than the $2 \times 4$ timber missile reaching $181 \mathrm{mph}$ in an F3 tornado. Unlike the timber missile, the steel pipe does not shatter into splinters. The mass of the wall barrier must be larger for the high speed impacts than required for smaller impact speeds.

Because the design tornado wind speed for PC4 SCC's is an F4 rather than an F5 tornado, the recommended design impact speed for PC4 is a 3-in. diameter steel pipe (75 lb) at 75mph. The design wind speed for PC3 SSCs is an F3 tornado. The F3 tornado is not nearly as wide as the F5 (see Table 3.3). The number of pipe missiles distributed in an F3 tornado is much less and the maximum impact speed is somewhat less. The recommended missile impact speed is $50 \mathrm{mph}$ for PC3 SSCs. The pipe missile is elevated by the wind about $10 \mathrm{ft}$ in an F5 tornado (see Appendix B). If a missile is released at $50 \mathrm{ft}$, it falls as it accelerates horizontally. By the time the pipe reaches a speed of $75 \mathrm{mph}$ in a F4 tornado, its height above ground is $30 \mathrm{ft}$ or less. Likewise, by the time a pipe reaches $50 \mathrm{mph}$ in an F3 tornado its height above ground is $30 \mathrm{ft}$ or less. Thus, the recommended maximum height of the 3-in. diameter pipe is $30 \mathrm{ft}$ and $50 \mathrm{ft}$ for PC3 and PC4 SSCs, respectively. 


\section{TORNADO MISSILE IMPACT CRITERIA}

\subsection{Introduction}

As discussed earlier, missiles transported by a tornado can vary in size and weight. Upon impact, a missile can spall, scab, penetrate or perforate a wall or roof structure as illustrated in Figure 4.1. Impact test data have been published on light and heavyweight missiles. Beason, Lynn and Minor (1976) tested lightweight missiles in the form or roof gravel impacting in window glass. Heavyweight missile impact tests were conducted by Vassallo (1975) Stephenson (1975) tested one 74 lb, 3-in. diameter steel pipe among his other tests. No other test data on 3-in. diameter pipe impacts was available, thus leaving a large gap in test data for this projectile and suggesting the need for further impacting testing.

Information gathered from impact tests reported herein will benefit engineers and contractors in the design and/or evaluation of SSCs required to resist tornado-generated missiles. The data will enable engineers to optimize their designs and avoid over design of SSCs. In evaluating existing SSCs, designers will be able to determine safe areas for occupant protection and sensitive materials during a tornado event. Finally, recommendations are prescribed that establish minimum barrier standards for impact of both the $2 \times 4$ timber plank and the 3 -in. diameter steel pipe. These standards satisfy DOE STD 1020-94 impact criteria.

The objectives of this experimental study are as follows:

1. Impact clay brick, concrete masonry, and reinforced concrete wall sections with 3-in. diameter steel pipe at various impact speeds 


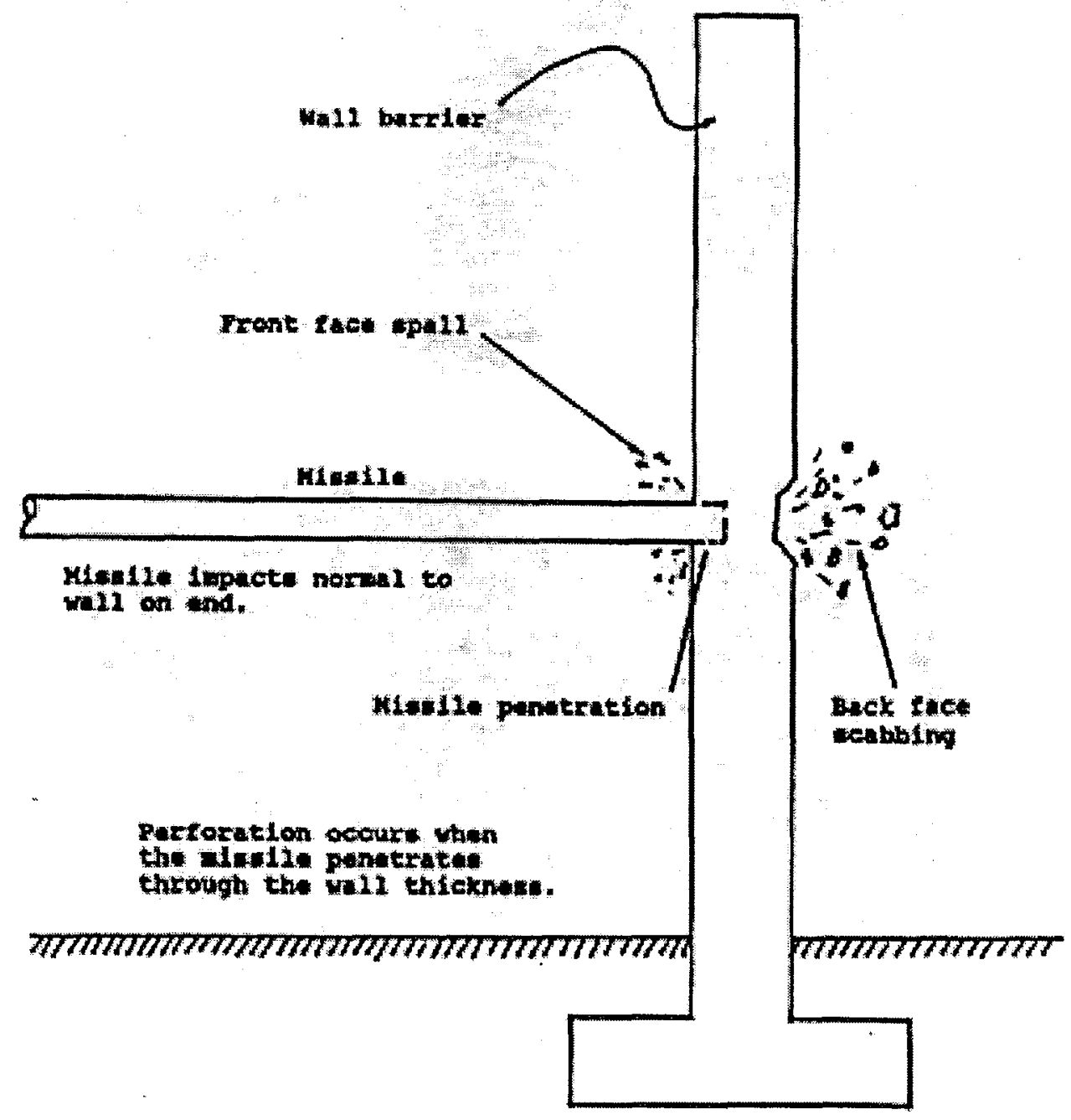

FIGURE 4.1 MISSILE IMPACT NOMENCLATURE 
2. examine the effect of different rebar patterns in concrete barriers

3. identify specific wall and roof barriers that are capable of safely resisting impact of missiles specified in DOE 1020-94.

To accomplish these objectives, twelve test specimens of various configurations were constructed in accordance with industry standards. Each was impacted by a steel pipe shot from an air-actuated cannon at a specified impact speed. Damage was identified as hairline cracks, penetration, front face spall, back face scabbing, or perforation. These data are then used with existing $15 \mathrm{lb} 2 \times 4 \mathrm{in}$. impact test data to formulate a complete set of medium weight missile impact standards.

The scope of this study is limited to testing barriers required to meet criteria specified in DOE STD 1020-94. A review and assimilation of test results for the $15 \mathrm{lb}$ $2 \times 4$ in. timber plank missile is included, but the study mainly concentrates on the impact resistance of clay brick masonry, concrete masonry, and reinforced concrete barriers to the steel pipe missile. Neither the wind forces necessary to pick up and transport a steel pipe, nor the probability of such a missile event is addressed in this study. For SSCs classified PC4, the $3000 \mathrm{lb}$ automobile traveling at an impact speed of $25 \mathrm{mph}$ requires structural responsc calculations that are also beyond the scopc of these project (see, for example, McDonald and Zang, 1993).

Subsequent chapters contain the following information: Section 4.2 reviews previous research relating to missile impact, while Section 4.3 explains design of the experiment. Section 4.4 describes the test facilty, and Section 4.5 focuses on the laboratory procedures and test panel construction. Section 4.6 presents the data from each test and examines the results of these experiments. A summary of results and a 
minimum impact criteria chart for the $2 \times 4$ plank and steel pipe missiles are given in Section 4.7. Finally, Section 4.8 provides the conclusion and recommendations.

\subsection{Review of Previous Research}

The impact of lightweight and heavyweight missiles has been studied previously. Lightweight missiles typically damage window glass. Heavyweight projectiles are tested for design of nuclear power plants. Impact tests of medium weight missiles are treated in this report.

\subsubsection{Previous Research on $2 \times 4$ Timber Plank Impacts}

Bailey (1984) conducted tests on typical residential walls using $15 \mathrm{lb}, 2 \times 4$ timber missiles. These tests were conducted in the Tornado Missile Impact Facility at Texas Tech University. In his research, Bailey tested barriers made of stucco, lapboard, plywood, masonite, concrete masonry, and clay brick masonry, which characterize typical residential exterior walls as defined in Architectural Graphic Standards (1981). Table 4.1 shows that most walls tested were perforated at about $50 \mathrm{mph}$ except the clay brick veneer wall was able to resist perforation of the $2 \times 4$ timber missile at speeds up to $120 \mathrm{mph}$.

White (1986) continued Bailey's research by testing a more extensive set of concrete masonry unit (CMU) walls for resistance to the $15 \mathrm{lb}, 2 \times 4$ timber plank. The CMU walls varied in thickness and amount of reinforcement. The walls that were reinforced and grouted provided substantial impact resistance. Most tests were conducted with the impact normal to the wall surface. A few tests shot provided impact at oblique 
angles to the wall. The normal impact turned out to be worst case. Most tests were conducted with a blunt-ended missile; others had a sharp, pointed end. The $2 \times 4$ missiles with pointed ends perforated the unreinforced CMU walls more easily than the bluntended ones, but it made little difference on the walls that were grouted. The results of White's impact tests are summarized in Table 4.2.

A series of unpublished impact tests on reinforced concrete panels were conducted at Texas Tech University in 1989 (Table 4.3 summarizes the results). Concrete compressive strength was a nominal 4000 psi. Rebar was Grade 40 . All panels were cured for at least 28 days. The panels were impacted normal to the surface, on end by a blunt ended $2 \times 4$ timber missile weighing 15 lbs. The 4-in. thick unreinforced test panel was impacted at $122 \mathrm{mph}$. The missile did not penetrate the concrete, but a vertical crack propagated through the panel thickness. The $2 \times 4$ timber missile was reduced to splinters. Number three rebar (3/8-in. diameter) was added to the second 4 -in. thick test panel. It experienced no damage when impacted at $121 \mathrm{mph}$. A second shot at $147 \mathrm{mph}$ on the same panel produced hairline cracks on the back face. The missiles were splintered. A 6-in. panel with similar reinforcement experienced no damage from the impact of the $2 \times 4$ timber plank. From these and other tests with similar results it was concluded that 4-in. reinforced concrete slab with a minimum reinforcement of \# 3 rebar at 6 -in. on center each way in center of slab is sufficient to stop the $15 \mathrm{lb}, 2 \times 4$ timber missile at impact speeds expected in tornado winds. 
Table 4.1 Impact Speed to Perforate Typical Residential Wall Panels (Bailey, 1984), (2x4 - 15 Ib. Timber Missile)

\begin{tabular}{|l|c|}
\hline \multicolumn{1}{|c|}{ Panel Description } & $\begin{array}{c}\text { Perforation } \\
\text { Velocity } \\
\text { (mph) }\end{array}$ \\
\hline Masonite Siding & 54 \\
Insulation Board / Masonite Siding & 54 \\
Plywood (1/2 in.) / Masonite Siding & 52 \\
Plywood (1/2 in.) & 52 \\
Plywood (3/4 in.) & 53 \\
Stucco Wall & 53 \\
Lapboard Siding & 53 \\
Insulation Board / Lapboard Siding & 52 \\
Brick Veneer & 122 \\
\hline
\end{tabular}

All barriers constructed on a $2 \times 4$ stud frame. 
Table 4.2 Impact Speed to Perforate CMU Walls

(White, 1986), (2x4 - 15 Ib. Timber Missile)

\begin{tabular}{|l|c|}
\hline \multicolumn{1}{|c|}{ Barrier Description } & $\begin{array}{c}\text { Perforation Velocity } \\
\text { (mph) }\end{array}$ \\
\hline 8-in. Wall & $>130$ \\
Grout and \#4 rebar in every cell & $>130$ \\
Grout only in every cell, no rebar & 65 \\
Grout and \#4 rebar in every other cell & $* *$ \\
Unreinforced & $* *$ \\
12-in. Wall & 60 \\
Grout and \#4 rebar in every cell & $>130$ \\
Grout only in every cell, no rebar & \\
Grout and \#4 rebar in every other cell & \\
Horizontal Joint Reinforcement only & \\
Unreinforced $^{* *}$ & 70 \\
\hline
\end{tabular}

* Although walls were not perforated, they suffered severe cracking

** Impact point was on cells which were not reinforced and grouted 
Table 4.3 Tornado Missile Impact Tests on Reinforced Concrete Panels (Texas Tech University, 1989), (2x4 - 15 Ib. Timber Missile)

\begin{tabular}{|c|c|c|}
\hline Barrier Description & $\begin{array}{c}\text { Impact Velocity } \\
\text { (mph) }\end{array}$ & Results \\
\hline $\begin{array}{l}\text { 4-in. thick. rReinforced concrete panel; } \\
\text { \#3 reinforcing bars spaced 6-in. o.c. each way } \\
\text { and placed in the middle of the panel - Test\#1 }\end{array}$ & 121 & $\begin{array}{l}\text { No damage; the } 2 \times 4 \text { timber plank } \\
\text { was reduced to splinters. }\end{array}$ \\
\hline $\begin{array}{l}\text { 4-in. thick, reinforced concrete panel; } \\
\text { \#3 reinforcing bars spaced 6-in. o.c. each way } \\
\text { and placed in the middle of the panel - Test\#2 }\end{array}$ & 147 & $\begin{array}{l}\text { Hairline cracks on the back face; the } \\
2 \times 4 \text { timber plank was reduced to } \\
\text { splinters. }\end{array}$ \\
\hline 4-in. thick. unreinforced concrete panel; & 122 & $\begin{array}{l}\text { No penetration, but a } 0.24 \text {-in. vertical } \\
\text { crack propagated through the panel; } \\
\text { the } 2 \times 4 \text { timber missile was reduced } \\
\text { to splinters. }\end{array}$ \\
\hline $\begin{array}{l}\text { 6-in. thick, reinforced concrete panel; } \\
\text { \#3 reinforcing bars spaced 6-in. o.c. each way } \\
\text { and placed in the middle of the panel. }\end{array}$ & 140 & $\begin{array}{l}\text { No damage; the } 2 \times 4 \text { timber missile } \\
\text { was reduced to splinters. }\end{array}$ \\
\hline
\end{tabular}




\subsubsection{Previous Research on 3-in. Diameter Steel Pipe Impacts}

A single impact test using a 3 -in. diameter Schedule 40 steel pipe missile weighing 75 lbs was conducted by Stevenson (1975). The 12-in. thick reinforced concrete test panel was struck by the pipe at a speed of $142 \mathrm{mph}$. Damage to the panel consisted of a 4.6 in. penetration crater at the impact point and hairline cracks on the back face. Although this test gave an indication of the impact resistance of reinforced concrete walls to steel pipe impacts, more data are needed on reinforced concrete panels with smaller thicknesses, along with concrete masonry and clay brick masonry walls. Also, pipe impact speeds slower than in Stevenson's test were needed to establish wall barrier design criteria in accordance with minimum missile criteria specified in DOE STD 102094.

\subsubsection{Impact Equations}

Two emperical equations have been proposed for predicting the impact resistance of concrete panels to tornado generated missiles. The equations are commonly known as the Rotz equation and Modified NDRC Equation. Vassolla (1975), conducted impact tests using medium and heavyweight missiles. The tests involved 8-in. diameter timber utility poles, 8 in. diameter steel pipes, and solid steel slugs impacting on 9 -ft by $9-\mathrm{ft}$ reinforced concrete panels. The panels were 12,18 , or 24 in. thick. These impact tests yielded data on both local damage and structural response effects on the panels. Local damage turned out to be the dominant damage factor for these missilcs. 
Rotz (1975) used data from the Vassolla tests to develop an empirical equation for determining the thickness of reinforced concrete slabs required to prevent back face scabbing from the impact of steel pipe missiles. The equation is:

$$
\mathrm{T}_{\mathrm{bs}}=5.44 * \mathrm{~W}^{0.4} * \mathrm{~V}_{\mathrm{s}}^{0.65} /\left(\mathrm{f}^{1} \mathrm{c}^{0.5} * \mathrm{D}^{0.2}\right)
$$

where:

$\mathrm{T}_{\mathrm{bs}}=$ thickness of concrete at threshold of back face scabbing, in.

$\mathrm{W}=$ missile weight, $\mathrm{lb}$

$\mathrm{D}=$ missile diameter, in

$\mathrm{V}_{\mathrm{s}}=$ missile impact speed fps

$\mathrm{f}^{1}{ }_{\mathrm{c}}=$ concrete compressive strength (psi)

Although Rotz developed this equation from 8-in. diameter steel pipe impact tests, he suggests that the equation is valid for other pipe diameters.

The Rotz equation has limitations. Because the equation is not non-dimensional, it can theoretically apply only to the slab thickness and missiles tested in Vassallo's research. Additional tests that could confirm the applicability of the Rotz equation to other missiles, impact speeds and slab thickness did not exist prior to the present study. Despite these limitations, the Rotz equation has potential application to 3-in. diameter pipes and reinforced concrete barriers.

The National Defense Research Committee (NDRC) formula, which was originally based on ballistic missile tests, was later modified by Kennedy (1975) to be applicable for tornado generated missiles. The modified formula is follows:

$$
t_{s} / D=7.91(X / D)-5.06(X / D)^{2} \quad \text { for } t^{s} / D<3
$$

or 


$$
t_{s} / D=2.12+1.36(X / D) \quad \text { for } t^{s} / D>3
$$

where:

$t_{s}=$ thickness for threshold of back face scabbing in.

$\mathrm{D}=$ missile diameter in.

$X=$ depth of penetration in.

$\mathrm{X}$ is found from the following formula:

$\mathrm{G}(\mathrm{X} / \mathrm{D})=\left(\mathrm{KND}^{0.02} \mathrm{~W}(\mathrm{~V} / 1000)^{1.8}\right) / \mathrm{D}^{3}$

where:

$$
\begin{aligned}
& V=\text { missile velocity fps } \\
& G(X / D)=(X / 2 D)^{2} \quad \text { for } X / D \leq 2.0 \quad \text { or } \\
& G(X / D)=(X / D-1) \quad \text { for } X / D>2.0 \\
& N=\text { shape factor of } 0.72 \text { for blunt-ended missiles } \\
& W=\text { weight of missiles } 1 b \\
& K=180 /\left(f^{1}\right)^{0.5} \\
& f^{1}{ }_{c}=\text { compressive strength of concrete psi }
\end{aligned}
$$

Figure 4.2 compares the threshold of back face scabbing thickness of reinforced concrete barriers as predicted by the Rotz equation and the modified NDRC equation for 3-in. diameter steel pipes. The results from the two equations are similar, although the Modified NDRC equation predicts a slightly larger (more conservative) concrete thickness for 3-in. diameter pipes impacting at the same speed. The Rotz equation was used to estimate test barrier thickness in the design of experiments for the research reported herein. 
Both the Rotz and the modified NDRC equations give reasonable predictions of concrete wall and roof panel thickness for protection against 3-in. diameter steel pipe impacts. The results are conservative when compared to impact test results.

\subsection{Design of Experiment}

The primary objective of the Texas Tech University test was is to identify wall and roof panels that are capable of resisting impact by 3-in. diameter steel pipe as specified in DOE STD 1020-94. In addition, several rebar patterns were considered for their effect on impact resistance. To accomplish these objectives, a series of reinforced concrete and masonry panels were designed, constructed, and tested. Design of the test program is described in this section.

Several variables influenced the design of the reinforced concrete and masonry test panels. DOE STD 1020-94 specifies that panels must resist the impact of 3-in. diameter steel pipe at speeds of 35,50 , or $75 \mathrm{mph}$. The different impact speeds translate into different impact loads which, in turn, affect panel thickness and strength requirements. Concrete, masonry and steel strengths, as well as the percent of steel and its arrangement within the panel, are all parameters that affect panel impact resistance. The missile impact angle (normal or oblique) also affects the damage inflicted on the test panel. 


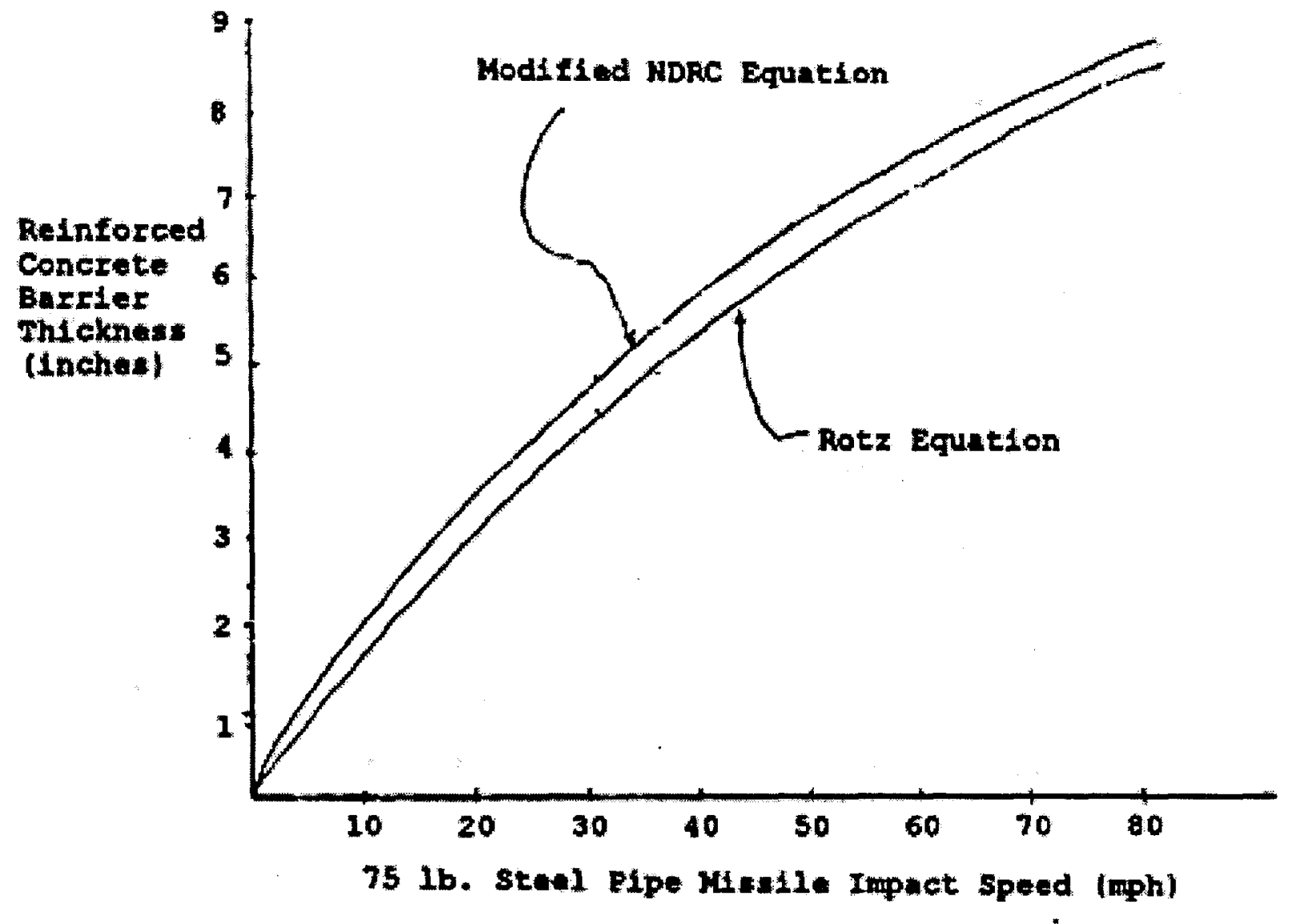

FIGURE 4.2 COMPARISON OF ROTZ AND MODIFIED NDRC EQUATIONS FOR THRESHOLD OF BACK FACE SCABBING 
Test panel designs were targeted to be close to the threshold of failure, but should not fail. Failure is define as the threshold impact velocity to produce back face scabbing rather than perforation. Back face scabbing dislodges pieces of the panel that become missiles capable of injuring people or damaging objects or equipment inside the building. Material strengths of the panels were held constant to minimize the number of variables in the tests. The strength characteristics are similar to those found in typical building construction.

The concrete panels were reinforced with close to the minimum percentage of steel allowed by the American Concrete Institute (ACI) 318-89 Building Code Requirements. Concrete panels containing approximately $0.50 \%$, steel are determined as shown in Appendix E. Providing the same percentage of steel in each test specimen allowed for panel consistency and comparability. In addition, the minimum amount of steel reinforcement represents the minimum strength case. This case was chosen so that minimum criteria for impact resistant barriers could be identified.

Masonry panels were reinforced according to current industry standards. Previous impact tests on masonry walls also influenced the amount of reinforcement in the wall panels.

All test panels were impacted with a blunt-ended missile striking on end, normal to the wall. During a tornado event, the wind transports missiles by random tumbling; the missiles rarely strike on end and normal to the wall. Normal impact is considered the worst case.

Each test panel was assigned an identification symbol. The first part identifies the panel construction. CR stands for reinforced concrete construction and CMU represents 
concrete masonry construction $\mathrm{CBM}$ and $\mathrm{CBCMU}$ refer to clay brick masonry and clay. brick/concrete masonry unit construction, respectively. The second part of the test panel symbol identifies slab thickness and panel number. For example, CR-8.1 indicates a reinforced concrete slab 8 -in. thick and is the first with these characteristics. The following paragraphs describe the test panels.

\subsubsection{Reinforced Concrete Panels}

Eight reinforced concrete panels of different thicknesses were constructed to resist 3-in. diameter steel pipe impacts. Panel thicknesses were chosen to resist impact speeds of 35,50 , and $75 \mathrm{mph}$. Concrete thickness required to prevent back face scabbing were estimated using the Rotz equation. Each panel was 39-in. x 39-in. Descriptions of the eight concrete test panels are presented in Table 4.4.

Three 6-in. reinforced concrete panels were constructed to test the steel pipe impact at $35 \mathrm{mph}$. The Rotz equation predicted that a 4.98 -in. thick slab was required to prevent back face scabbing. In order to assure a design that would not fail, a 6-in. thickness was selected. Three 6-in. slabs were constructed. Each had the same percentage of steel, but a different arrangement of the reinforcing bars.

Three 8-in. reinforced concrete panels were designed to resist impact of the steel pipe traveling $50 \mathrm{mph}$. The Rotz equation predicted that a 6.29 -in. thickness was required to resist back face scabbing. An 8-in. panel was chosen to ensure that a failure did not occur. Arrangements of the reinforcing steel had specific objectives. In CR-8.1 and CR-8.2, the effect of 9-in. and 12-in. reinforcing spacing (each way) was examined. The effect of reinforcing near both faces of the concrete was studied in CR-8.3. 
Table 4.4 Reinforced Concrete Panel Construction

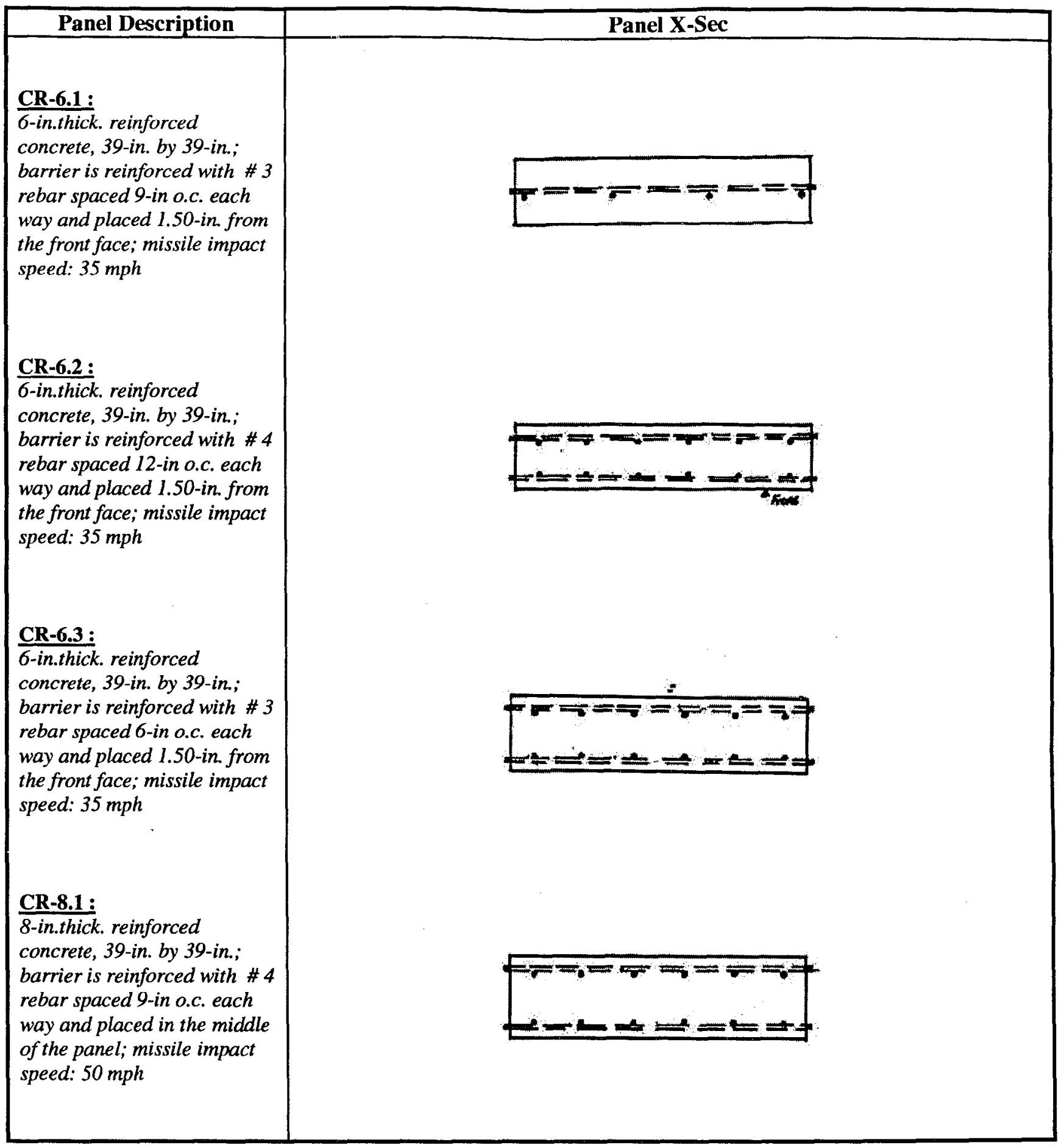


Table 4.4 Reinforced Concrete Panel Construction (cont.)

\begin{tabular}{|c|c|}
\hline Panel Description & Panel X-Sec \\
\hline $\begin{array}{l}\text { CR-8.2: } \\
\text { 8-in.thick. reinforced } \\
\text { concrete, } 39 \text {-in. by } 39 \text {-in.; } \\
\text { barrier is reinforced with \# } 4 \\
\text { rebar spaced } 12 \text {-in o.c. each } \\
\text { way and placed in the middle } \\
\text { of the panel; missile impact } \\
\text { speed: } 50 \text { mph }\end{array}$ & $\Delta+x \rightarrow-2=0=0$ \\
\hline $\begin{array}{l}\text { CR-8.3: } \\
\text { 8-in.thick. reinforced } \\
\text { concrete, 39-in. by } 39 \text {-in.; } \\
\text { barrier is reinforced with \# } 3 \\
\text { rebar spaced } 12 \text {-in o.c. each } \\
\text { way and placed 1.50-in. from } \\
\text { the front face; missile impact } \\
\text { speed: } 50 \text { mph }\end{array}$ & $\Rightarrow=\Rightarrow=\Rightarrow$ \\
\hline $\begin{array}{l}\text { CR-9.(1\&2): } \\
\text { 9-in.thick. reinforced } \\
\text { concrete, } 39 \text {-in. by } 39 \text {-in.; } \\
\text { barrier is reinforced with \# } 4 \\
\text { rebar spaced 6-in o.c. each } \\
\text { way and placed } 1.50 \text {-in. from } \\
\text { the front face; missile impact } \\
\text { speed: } 75 \text { mph }\end{array}$ & $F F \equiv \equiv \equiv \equiv \equiv$ \\
\hline $\begin{array}{l}\text { CR-10.1: } \\
\text { I0-in.thick. reinforced } \\
\text { concrete, } 39 \text {-in. by } 39 \text {-in.; } \\
\text { barrier is reinforced with \# } 4 \\
\text { rebar spaced 6-in o.c. each } \\
\text { way and placed 1.50-in. from } \\
\text { the front face; missile impact } \\
\text { speed: } 75 \text { mph }\end{array}$ & \\
\hline
\end{tabular}


The last two reinforced concrete panels were built to resist a $75 \mathrm{mph}$ impact speed. The Rotz equation predicted that an 8.21-in. slab was required to resist back face scabbing. Slabs with thicknesses of 9-in. and 10-in. were constructed. The 10-in. barrier was designed to further ensure satisfactory impact resistance. The rebar arrangement was the same in both panels. Each had No. 4 rebar at 6-in. o.c. each way placed 1.5 -in. from each face.

\subsubsection{Reinforced Masonry Panels}

Four masonry wall panels were built to test impacts of the steel pipe missiles.

Two panels were constructed with concrete masonry units (CMUs), while the other two consisted of a clay brick cavity wall and a clay brick/CMU combination. Reinforced masonry walls are widely used industrial applications. Unfortunately, there is no equation to estimate panel thickness to resist back face scabbing, as did the Rotz equation for reinforced concrete panels.

A schedule of the masonry wall panel construction is presented in Table 4.5. An 8-in. and a 12-in. CMU wall were built to resist the steel pipe impacting at 50 and 75 mph, respectively. Both the 8-in. and 12-in. nominal wall thicknesses are industry standards in construction. The CMU panels were 48 in. x 48 in.. All vertical cells in each wall were reinforced with \# 4 rebar and filled with grout. Horizontal reinforcement consisted of truss-type joint reinforcement, which was placed at every second course.

A 9.5-in. clay brick cavity wall and a 12-in. clay brick/CMU combination wall were designd to resist the $50 \mathrm{mph}$ impact of the steel pipe. The cavity wall was 52-in. high $x$ 48-in. wide, while the combination wall was 48 -in. $x$ 48-in. The cavity wall was 
filled with grout and reinforced with vertical rebar. Horizontal reinforcement consisted of truss-type joint reinforcement placed at every fifth brick course. The CMU's in the combination wall were reinforced in the same way as the other two CMU walls. A single wythe of brick was mortared to the front face of the CMU wall. Horizontal truss-type joint reinforcement tied the CMU and brick wythes together; it was placed in every second CMU course.

\subsection{Experimental Facility}

The Tornado Missile Impact Facility (TMIF) at Texas Tech University simulates tornado generated missile impacts on wall or roof components. It contains an airactuated cannon that can accelerate a $15 \mathrm{lb} 2 \times 4$ timber plank or a $75 \mathrm{lb} 3$-in. diameter steel pipe up to speeds of $150 \mathrm{mph}$ and $75 \mathrm{mph}$, respectively. The facility is located in the basement of the Civil Engineering Testing Laboratory in the east chamber under the structural test deck. Plan and elevation views of the TMIF are shown in Figures 4.3 and 4.4. The test chamber is $60 \mathrm{ft}$ long, $9 \mathrm{ft}$ wide, and $7 \mathrm{ft}$ high. The TMIF facility consists of four primary components:

1. Missile launcher (cannon)

2. Control panel

3. Reaction frame

4. Timing gate 


\section{Table 4.5 Reinforced Masonry Barrier Schedule}

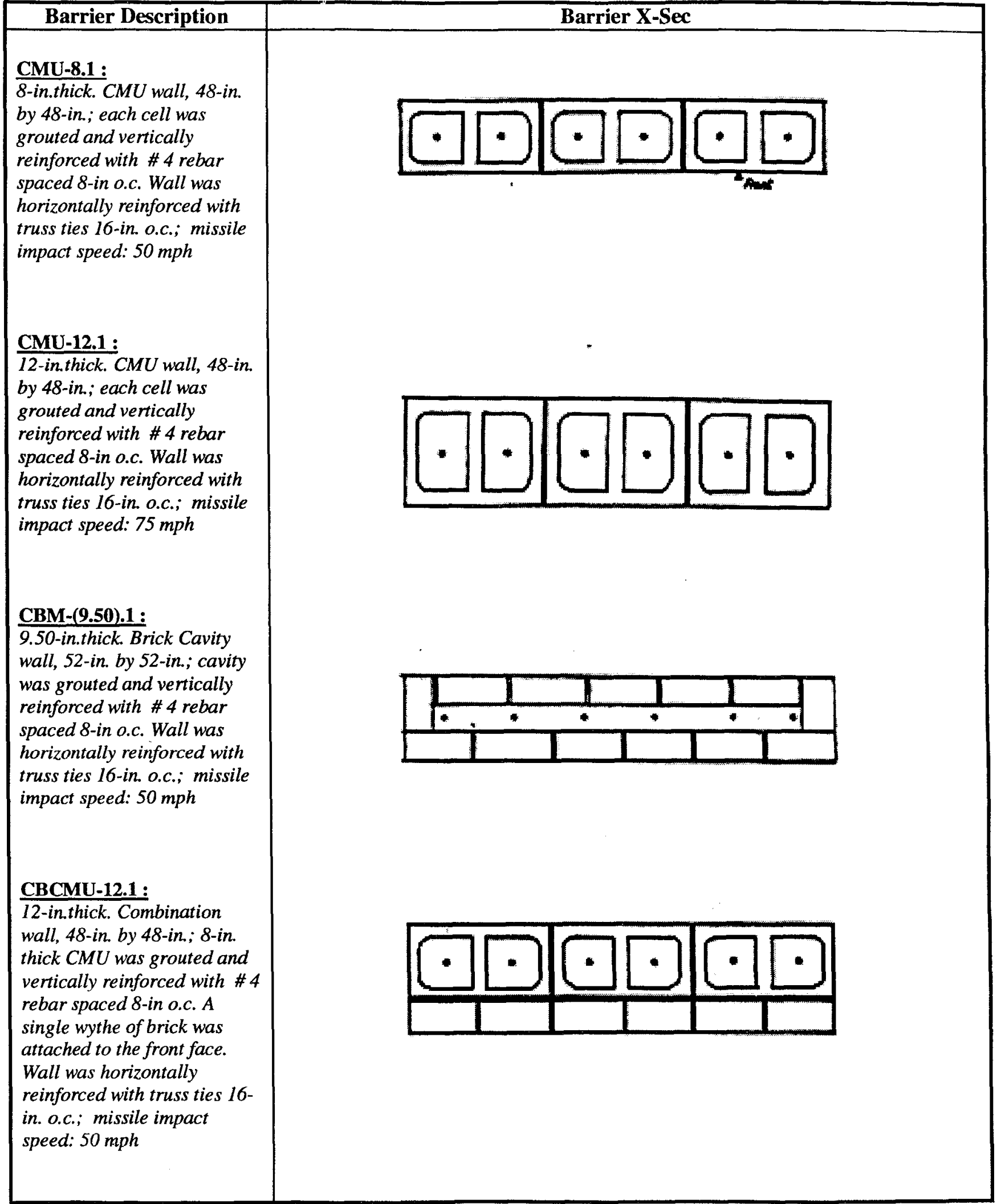


Table 4.6 Reinforcing Arrangement Comparison

\begin{tabular}{|c|c|c|c|c|}
\hline $\begin{array}{l}\text { Panel } \\
\text { Thick }\end{array}$ & $\begin{array}{c}\text { Reinforcing } \\
\text { Arrangement }\end{array}$ & $\begin{array}{c}\text { Missile } \\
\text { Impact Speed } \\
\text { (mph) }\end{array}$ & $\begin{array}{l}\text { Panel Damage } \\
\text { Description }\end{array}$ & Comments \\
\hline \multirow{3}{*}{ 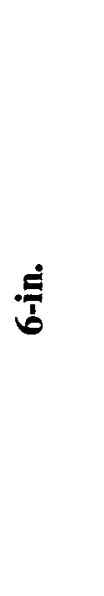 } & $\begin{array}{l}\text { CR-6.1: \#3 spaced 9-in. } \\
\text { o.c. each way, 1.5-in. from } \\
\text { panel front face }\end{array}$ & 35 & $\begin{array}{l}0.25 \text {-in. penetration; } 0.19 \text {-in. wide } \\
\text { radial cracks on back face, total } \\
\text { propagation }\end{array}$ & $\begin{array}{l}\text { Reinforcement in front face } \\
\text { reduced penetration depth }\end{array}$ \\
\hline & $\begin{array}{l}\text { CR-6.2: \#3 spaced 12-in. } \\
\text { o.c. each way, } 1.50 \text {-in. } \\
\text { from panel back face }\end{array}$ & 36 & $\begin{array}{l}0.38 \text {-in. penetration; } 0.06 \text {-in. wide } \\
\text { radial cracks on back face, total } \\
\text { propagation }\end{array}$ & $\begin{array}{l}\text { Reinforcement in back face } \\
\text { reduced radial crack size }\end{array}$ \\
\hline & $\begin{array}{l}\text { CR-6.3: \#4 spaced 9-in. } \\
\text { o.c. each way, } 1.50 \text {-in. } \\
\text { from panel back face }\end{array}$ & 37 & $\begin{array}{l}0.38 \text {-in. penctration; } 0.06 \text {-in. wide } \\
\text { radial cracks on back face, total } \\
\text { propagation }\end{array}$ & $\begin{array}{l}\text { Reinforcement in back facc } \\
\text { reduced radial crack size; } \\
\text { closer rebar spacing did not } \\
\text { influence damage }\end{array}$ \\
\hline \multirow{3}{*}{$\frac{\pi}{\infty}$} & $\begin{array}{l}\text { CR-8.1: \#4 spaced 9-in. } \\
\text { o.c. each way, in the } \\
\text { middle of panel }\end{array}$ & 44 & $\begin{array}{l}0.38 \text {-in. penetration; } 0.06 \text {-in. wide } \\
\text { radial cracks on back face, total } \\
\text { propagation }\end{array}$ & $\begin{array}{l}\text { Closer rebar spacing } \\
\text { appeared to reduce } \\
\text { penetration depth }\end{array}$ \\
\hline & $\begin{array}{l}\text { CR-8.2: \#4 spaced 12-in. } \\
\text { o.c. each way, in the } \\
\text { middle of panel }\end{array}$ & 44 & $\begin{array}{l}0.63 \text {-in. penetration; } 0.09 \text {-in. wide } \\
\text { radial cracks on back face, total } \\
\text { propagation }\end{array}$ & \\
\hline & $\begin{array}{l}\text { CR-8.3: \#4 spaced 12-in. } \\
\text { o.c. each way, } 1.50 \text {-in. } \\
\text { from each panel face }\end{array}$ & 50 & $\begin{array}{l}0.69 \text {-in. penetration; } 0.09 \text {-in. wide } \\
\text { radial cracks on back face, } 3 / 4 \\
\text { propagation }\end{array}$ & $\begin{array}{l}\text { Double rebar mats prevented } \\
\text { total propagation of cracks }\end{array}$ \\
\hline \multirow{2}{*}{$\dot{a}$} & $\begin{array}{l}\text { CR-9.1: \#4 spaced 12-in. } \\
\text { o.c. each way, } 1.50 \text {-in. } \\
\text { from each panel face }\end{array}$ & 50 & $\begin{array}{l}0.44 \text {-in. penetration; hairline radial } \\
\text { cracks on back face, } 1 / 2 \text { propagation }\end{array}$ & $\begin{array}{l}\text { Double rebar mats again } \\
\text { resist crack propagation } \\
\text { through panel }\end{array}$ \\
\hline & $\begin{array}{l}\text { CK-9.2: \#4 spaced 12-in. } \\
\text { o.c. each way, } 1.50 \text {-in. } \\
\text { from each panel face }\end{array}$ & 78 & $\begin{array}{l}1.50 \text {-in. penetration; scabbing, } 1.0 \text {-in. } \\
\text { by } 0.50 \text {-in. fragments. }\end{array}$ & $\begin{array}{l}\text { Double rebar mats again } \\
\text { resist crack propagation } \\
\text { through panel }\end{array}$ \\
\hline$\dot{\dot{g}}$ & $\begin{array}{l}\text { CR-10.1: \#4 spaced 12-in. } \\
\text { o.c. each way, } 1.50 \text {-in. } \\
\text { from each panel face }\end{array}$ & 74 & $\begin{array}{l}0.81 \text {-in. penetration; hairline radial } \\
\text { cracks on back face, } 1 / 2 \text { propagation }\end{array}$ & $\begin{array}{l}\text { Double rebar mats again } \\
\text { resist crack propagation } \\
\text { through panel }\end{array}$ \\
\hline
\end{tabular}




\subsubsection{Missile Launcher}

The missile launcher (sea Figure 4.5) is an air cannon that propels a missile to the desired impact speed. Air pressure is built up in a 60- gallon tank (see Figure 4.6). A 4in. diameter Schedule 80 Polyvinyl Chloride (PVC) manifold links the air tank to the back end of a 4 -in. diameter solid core ball valve (see Figure 4.7). The ball valve rapidly releases the compressed air when the firing mechanism is activated. Attached to the front end of the valve is a 4-in. diameter $\mathbf{x} 20$-ft long PVC pipe, which serves as the cannon barrel. Test missiles are muzzle-loaded into the barrel. The barrel is held by two supports, one at the middle of the barrel and one at the breech end. The breech support is braced against horizontal recoil by three angle struts that run along the floor to the back wall of the chamber. Both barrel supports are also braced against vertical recoil with sand bags.

To accelerate a missile to some desire speed, compressed air in the tank is released by remotely opening the ball valve. The ball valve is opened by a lever arm that is actuated by an air cylinder. A round plywood sabot is attached to the back end of the missile to prevent air from flowing through or around the end of the missile.

\subsubsection{Control Panel}

The control panel (see Figure 4.8) contains all the instrumentation and controls needed to safely fire missile and measure its impact speed. It is located outside the test chamber in an adjacent cell, well protected from missile impact debris. Along with air pressure control, the panel also controls electrical power for the firing mechanism and two safety releases. The control panel contains the following: 


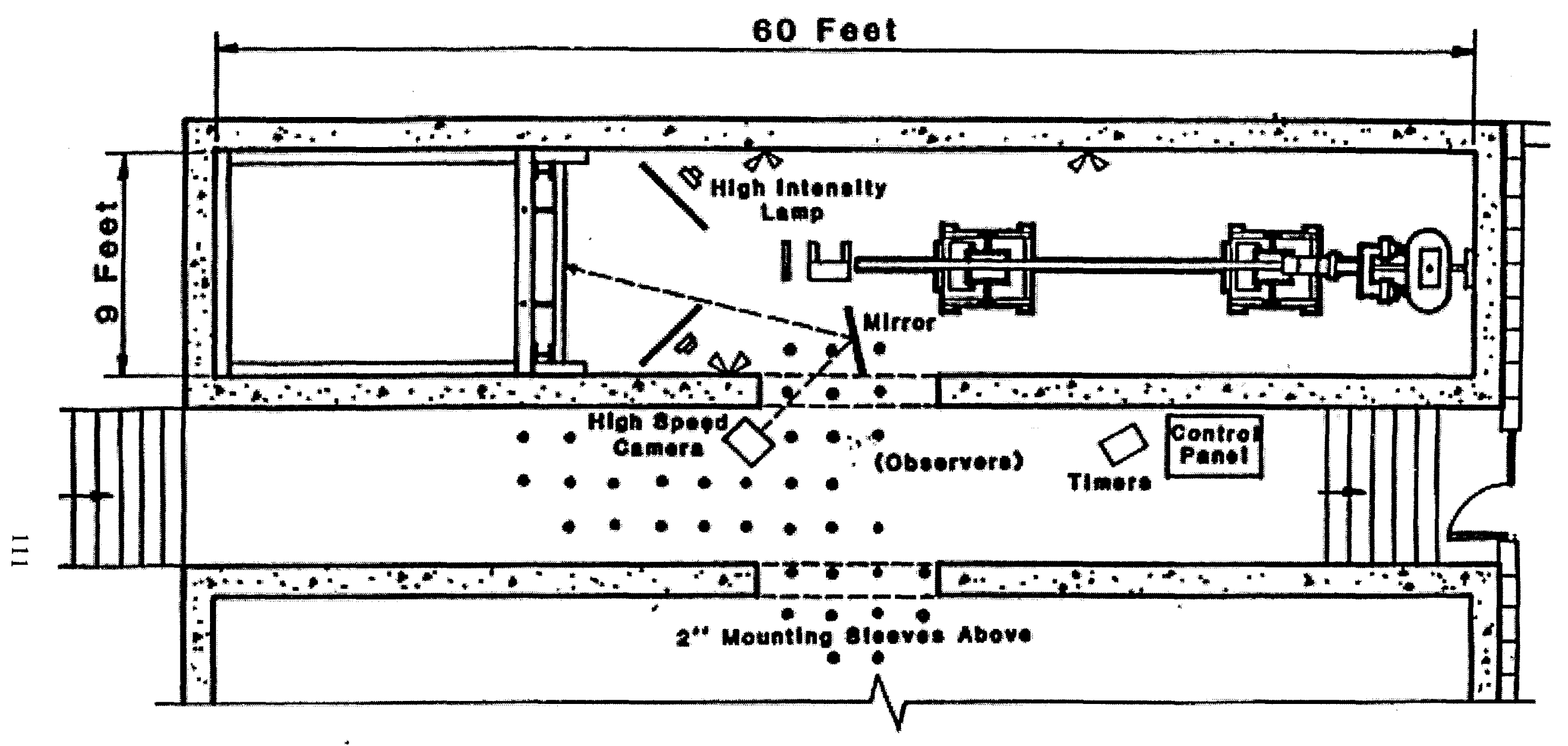

FIGURE 4.3 PLAN VIEW OF MISSILE LAUNCHING FACILITY 
FIGURE 4.4 ELEVATION OF MISSILE LAUNCHING FACILITY

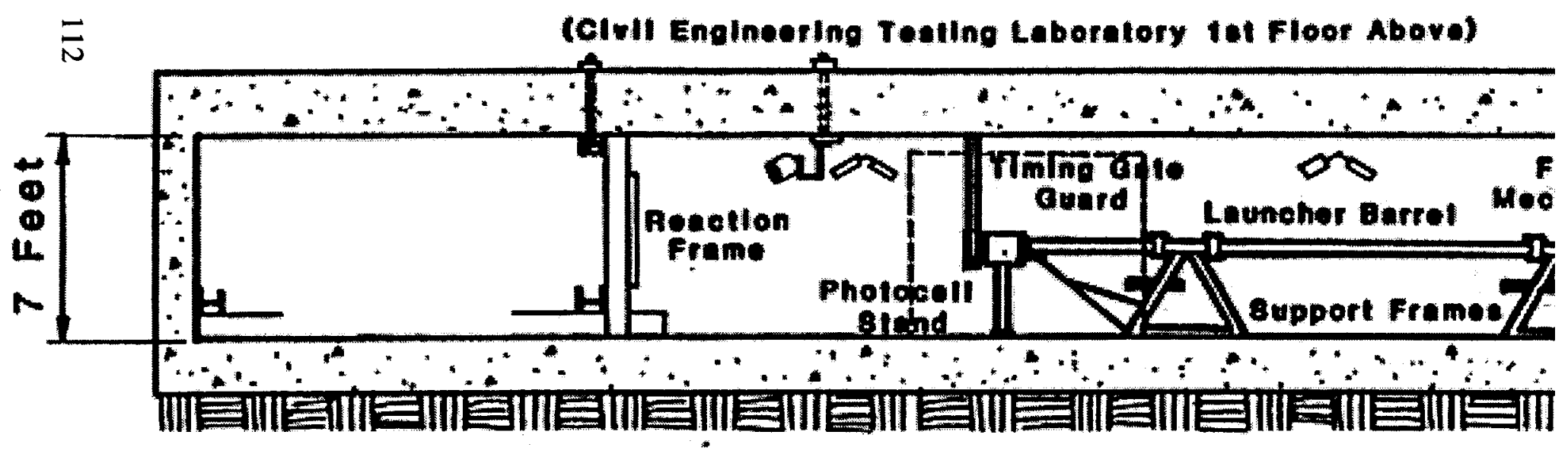



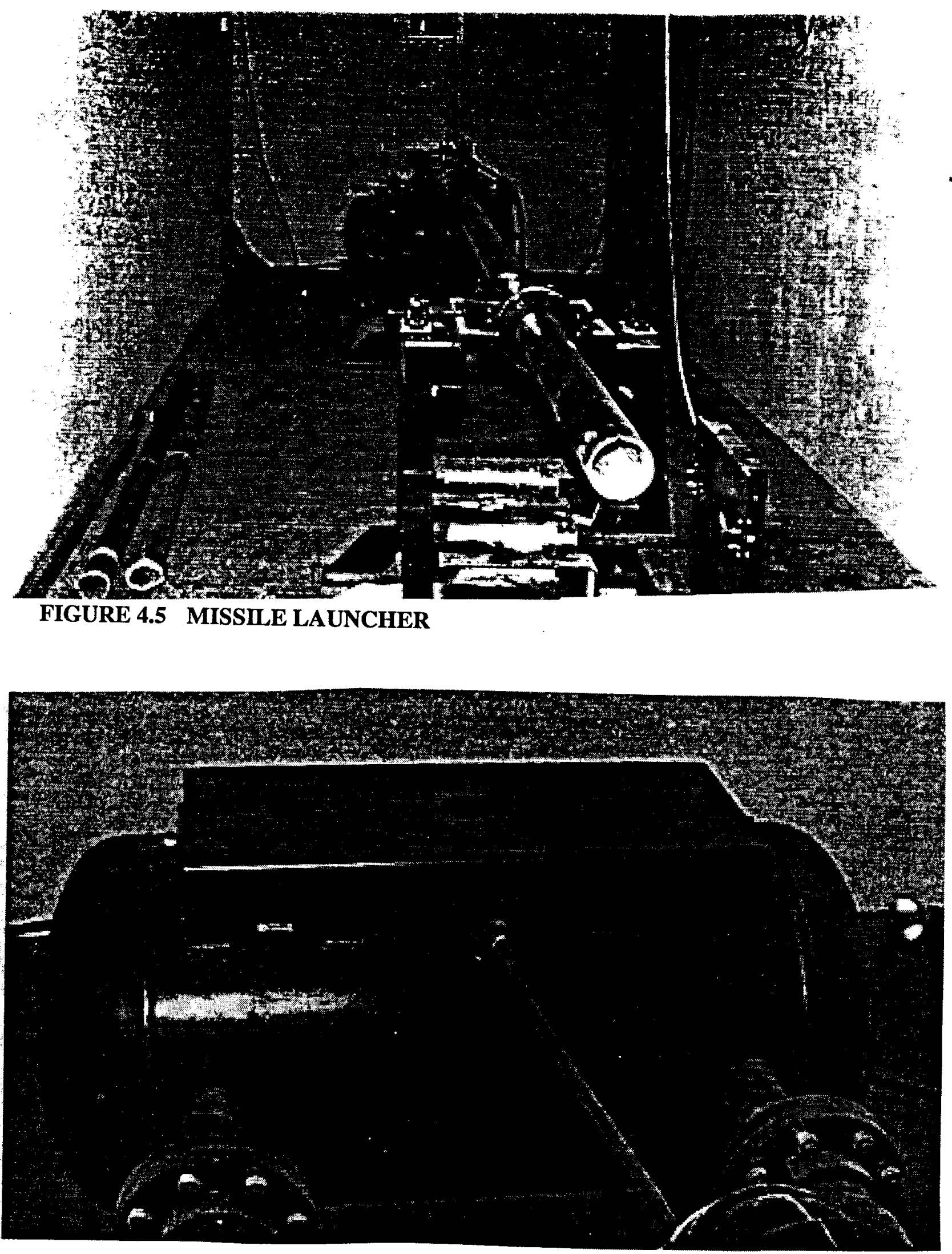

FIGURE 4.6 AIR TANK 


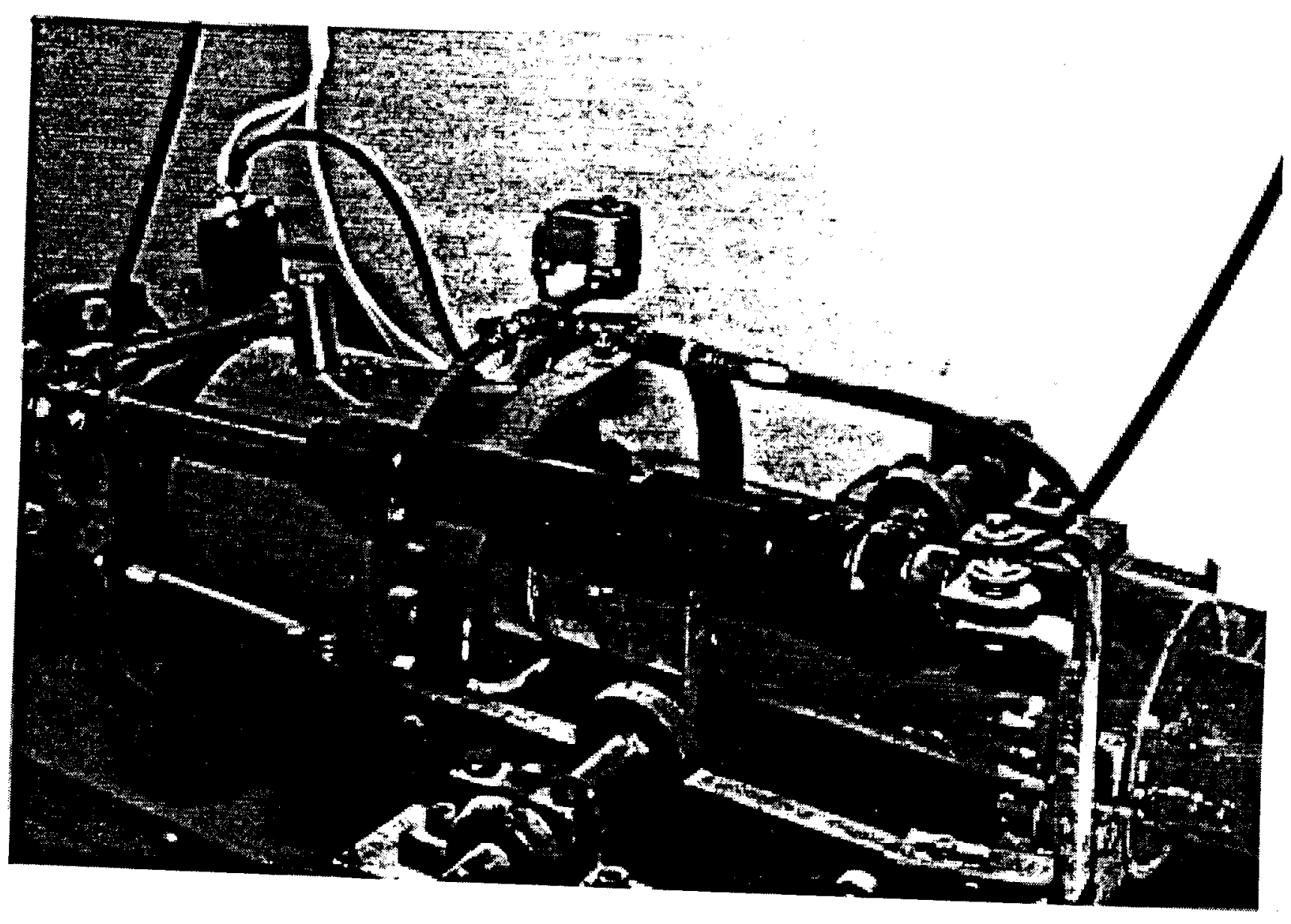

FIGURE 4.7 BALL VALVE ASSEMBLIES 


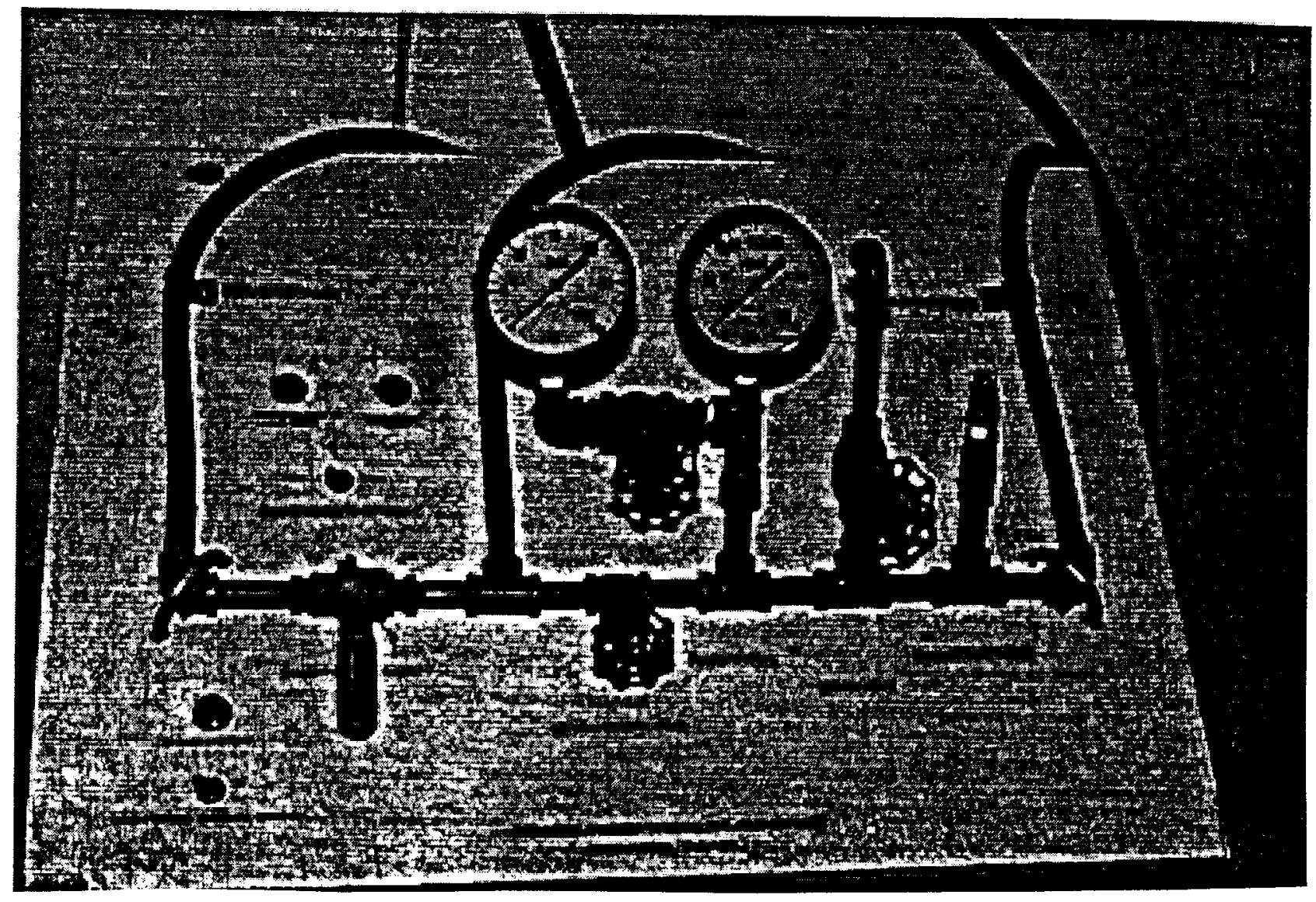

FIGURE 4.8 CONTROL PANEL 
1. Valves for pressurizing and releasing pressure in air the tank

2. A "trigger" that remotely opens the valve and "fires" the missile

3. Electrical switches that control a high speed movie camera

4. A pressure release valve

5. Indicator lights that show if the firing sequence was properly executed.

\subsubsection{Reaction Frame}

A Reaction frame provides rigid support for the test specimens (see Figure 4.9). The vertical members are W8x18 steel wide-flange beams; the horizontal members are W6x30. The base of the frame is supported by steel members that extend to the north end wall of the test cell. The top is fastened by bolts through sleeves in the ceiling. A hand wench attached to the top horizontal beam lifts test specimens for mounting in the reaction frame. A specimen rests on two $L 21 / 2 \times 21 / 2$ - in. angle seats that are welded to the bottom horizontal beams. Four C-clams secure the specimen to the two vertical beams. Once the test panel is in place, the reaction frame provides simple support conditions around the perimeter of the specimen.

\subsubsection{Missile Velocity Measurement System}

A photoelectric timing gate is used to measure the speed of the missile as its trailing end clears the barrel. At the end of the barrel, two light beams shine on two pairs of photo cells (see Figure 4.10), which are located one foot apart. The light beams are blocked by the missile as it leaves the barrel. When the trailing end of the missile passes the first pair of photo cells, the light beams starts the two independent timers (Figure 
4.11). When the end of the missile passes the second pair of photocells, the light beam stops the timer. The resulting measurement in milliseconds is the time for the trailing end of the missile to travel one foot. The reciprocal of this value is the speed of the missile in feet per second which is than be converted to miles per hour. Light emitting diodes on a circuit board indicate light source interruption, indicating that the timing circuits operated properly.

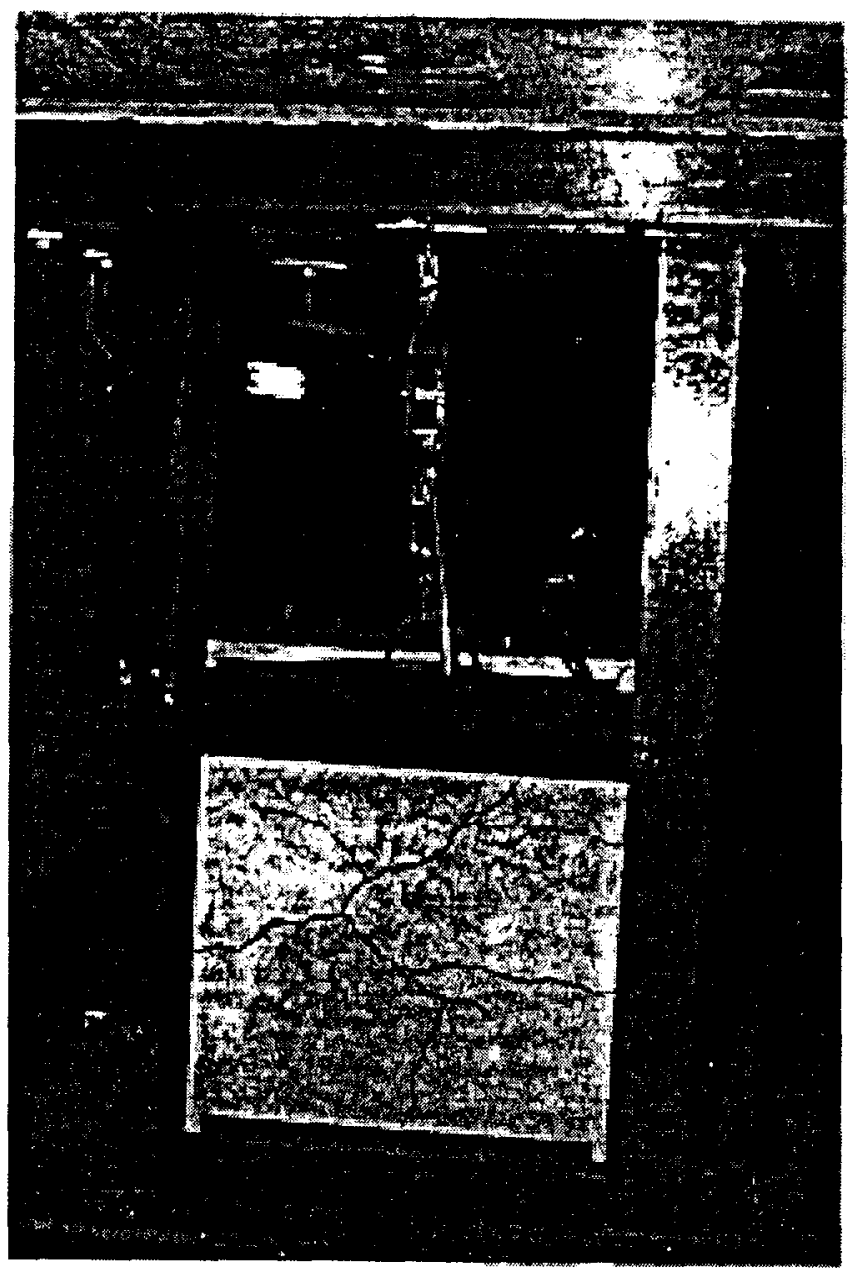

FIGURE 4.9 BACK SIDE OF REACTION FRAME 


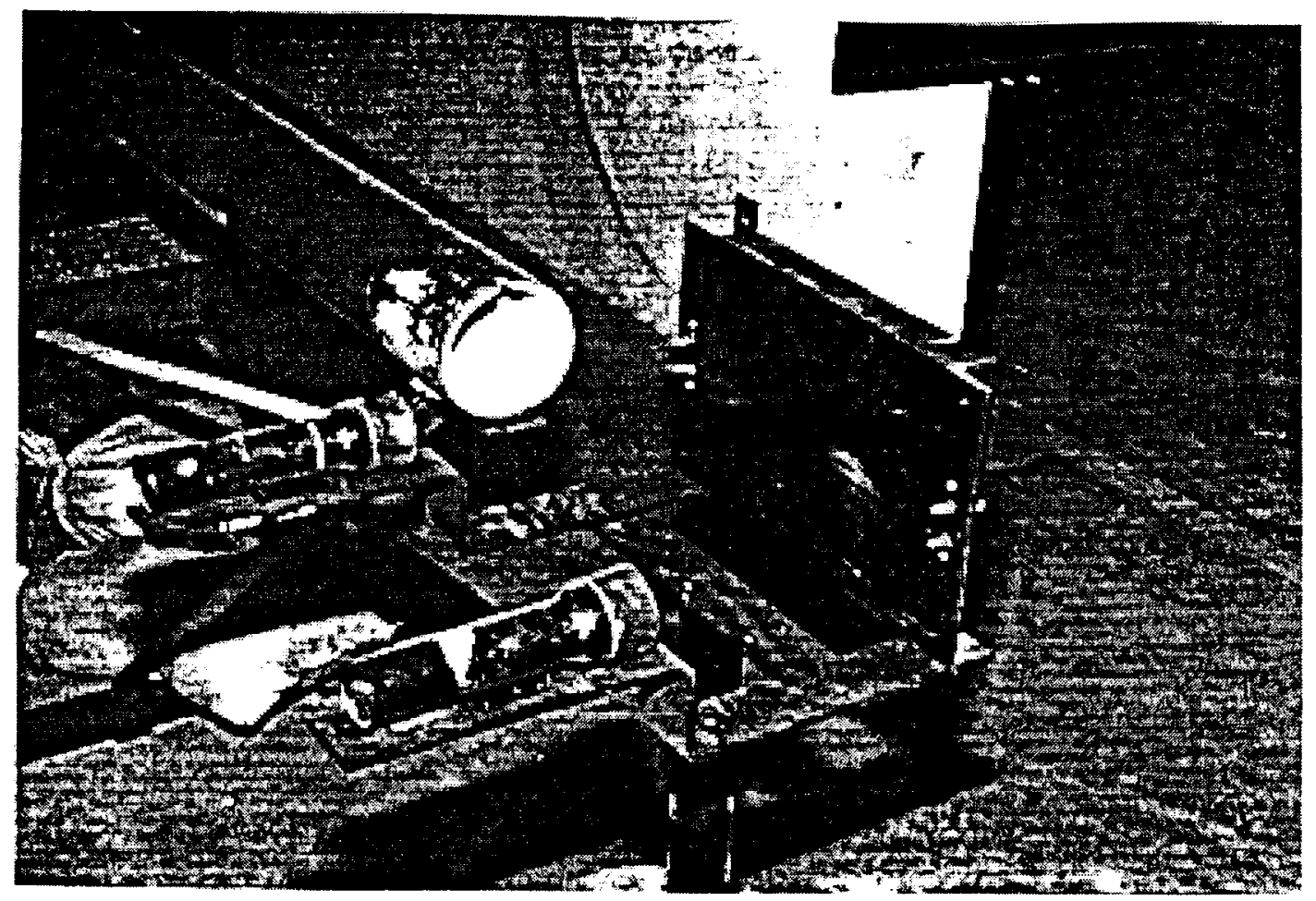

\section{FIGURE 4.10 TIMING GATES}

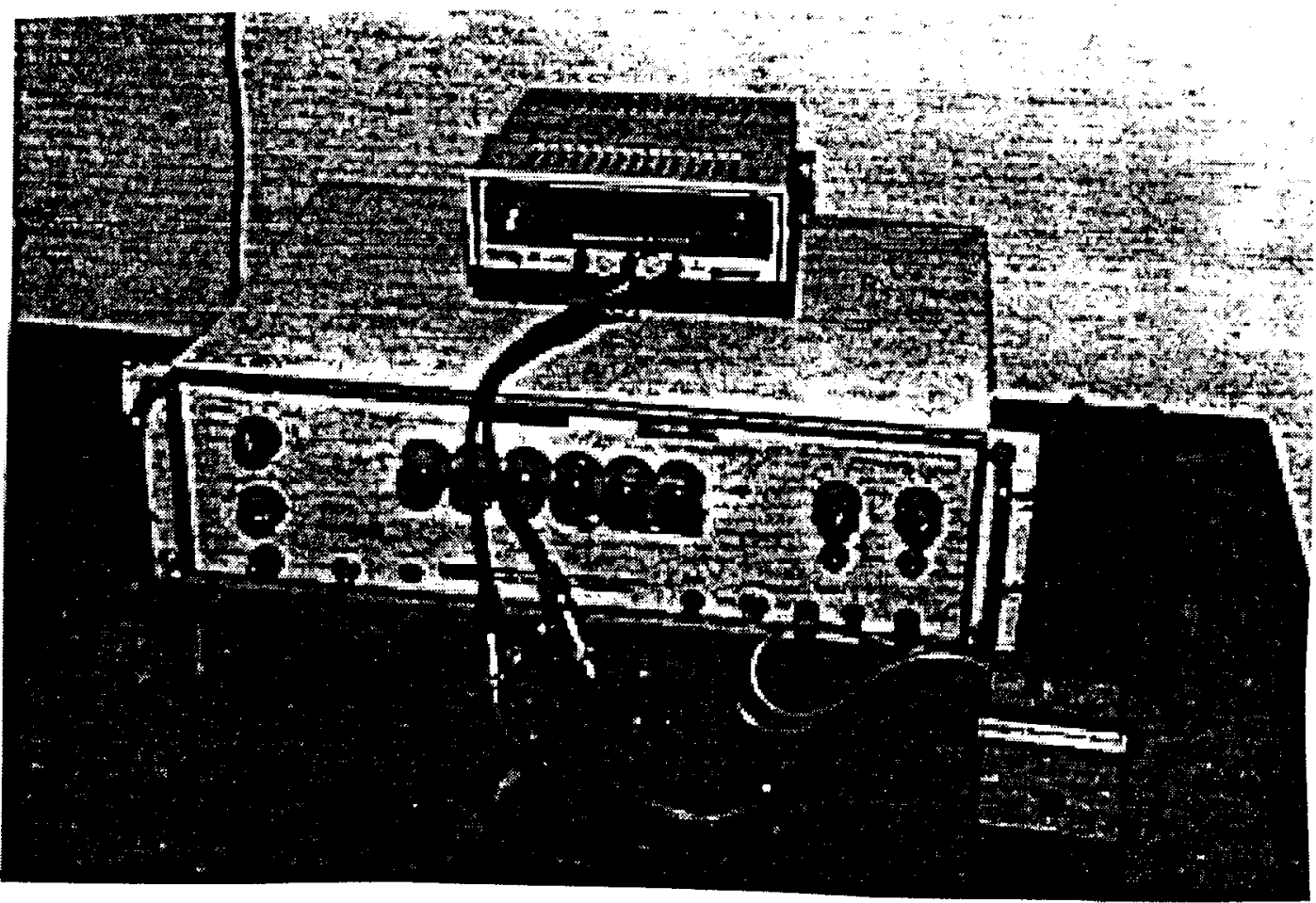

FIGURE 4. $11 \quad$ TIMERS 
The missile speed measuring system is calibrated by connecting an oscilloscope to the photocells. When the missile is fired, the wavelength frequency in milliseconds is compared to the missile speed measuring system's readings. Errors ranged from 0.74 mph at $20 \mathrm{mph}$ missile speed to $1.04 \mathrm{mph}$ at $75 \mathrm{mph}$ missile speed. See Appendix G for calibration test results.

The end of the cannon barrel is located so the missile impacts the test specimen within two to three feet after clearing the barrel. Hence, the missile speeds measured by the timing gate are essentially the impact speed of the missile.

\subsection{Material Properties and Procedures}

\subsubsection{Construction of Test Panels}

Eight 39-in.x39-in. reinforced concrete panels were cast in the Civil Engineering Testing lab. Grade 40 reinforcing bars were placed in each form; concrete was placed from the same batch mix to ensure that the concrete properties in all of the panels were the same. The concrete was obtained from a commercial ready-mix plant and had a target compressive strength of 4000 psi. After curing for 28 days in a $70^{\circ} \mathrm{F}$ environment, the concrete slabs were lowered to the basement and moved one at a time into the test chamber.

The concrete block (CMU) and clay brick masonry wall sections were built in the cell adjacent to the test chamber by a journeyman mason. The CMU blocks and the clay bricks were laid in a running bond pattern with Type $S$ mortar. Grade 40 reinforcing bars and grout meeting ASTM 476 specififications were placed in the wall sections. The panels were allowed to cure for at least seven days before testing. For both the concrete 
and masonry wall sections, standard construction practices were followed. Care was taken not to subject the panels to excessive loads during the movement. Samples of concrete, mortar, and grout were tested in the Texas Tech Civil Engineering Testing Laboratory. ASTM testing procedures were followed. Properties of the CMU block and clay bricks were obtained from tests performed on the material supplied.

\subsubsection{Material Properties}

The ready-mix concrete used in the construction of eight concrete test panels had a target compressive strength of 4000 psi 28 days. The mix design consisted of Type I Portland cement, sand, gravel (approximately 1.0-in. diameter), water, and Pozz LL761 and MBVR admixtures.

The masonry test panels consisted of CMUs, clay brick, mortar, grout, and rebar. The CMU widths were a nominal 8 in. and 12 in. The standard clay bricks were 2.25 in. high by 3.625 in. wide by 7.75 in. long. The Type $S$ mortar contained specific volumes of Type III Portland cement, sand, hydrated lime, and water. The grout contained specific volumes of Type I Portland cement with high early strength admixture, sand, pea gravel, and water.

The 3-in. diameter pipe missiles were approximately $10 \mathrm{ft}$ long. The Schedule 40 pipe weighs $7.58 \mathrm{lbs} / \mathrm{ft}$. The pipe had an outside diameter of 3.50in., an inside diameter of 3.07 in., and a cross sectional area of 2.23 in. $^{2}$. A pipe missile was not used more than three times became after each test, the impacted end was sawed to remove deformed material. 


\subsubsection{Testing Procedures}

An established testing procedure was followed to ensure accurate and repeatable test results. The test procedure can be divided into three main activities:

1. Prelaunch

2. Launch

3. Post launch

Detail description of the procedures are presented below.

\subsubsection{Prelaunch}

To start, a barrier is selected and mounted on the reaction frame, with four Cclams. The missile is weighed and a plywood sabot is attached to the end of the pipe. The missile impact speed is achieved by pressuring the air tank to a predetermined value. An air pressure versus missile velocity curve gives the appropriate air tank pressure. This curve was acquired by making a number of test shots at different pressures. Experience with this approach allows the missile to be fired within $\pm 2 \mathrm{mph}$ of the desired impact velocity. Still photographs of the panels are taken before the test. The VHS video camera is set up along with a high speed movie camera.. Timing gate light sources, timers, and circuit boards are turned on to activate the missile velocity measurement system. The timers are zeroed and the circuit board is reset. Finally, the missile is loaded into the barrel. 


\subsubsection{Launch}

To initiate the launch sequence the bleeder valve is closed and the air tank pressure control valve is opened. During pressurization, the video camera is turned on. The air tank control valve is closed when desired pressure is reached. The system is now ready to fire. Three seconds before firing, the high-speed camera is turned on. The missile is launched by quickly rotating the trigger control, which opens the valve between the air tank and the barrel. The released air pressure pushes against the sabot as the missile accelerates through the $20 \mathrm{ft}$ long barrel. The timing gate measures the missile speed as the trailing end of the missile clears barrel. After impact, the trigger is returned to the closed position and the bleeder valve is opened to release any pressure that remains in the air tank.

\subsubsection{Post Launch}

The timers are read and their values recorded. The power to the microswitch is also turned off. The operator then enters the chamber and resets the firing mechanism valve to the closed position. Still photographs and video footage of specimen are obtained. The speed of the missile is obtained using the average of the two timer readings and converting to miles per hour. Crack patterns, penetration depth, the debris shape and size, and other damage characteristics are recorded in detail on the test data sheet. The missile launching facility is then inspected for damage and the debris from the test is cleaned up. 


\subsubsection{Data Collection}

All data associated with an impact test are recorded on a test data sheet. These sheets are presented in Appendix C. Test data sheet information includes panel characteristics, missile characteristics, launch data, impact data, and other forms of documentation. Panel characteristics, include size, composition, strength, and age of the panel. The launch data include air tank pressure readings, missile velocity, and any additional comments made about the launch. Impact data consists of information on spall, penetration, scabbing, or perforation, along with information and comments concerning damage to the panels. Since the primary objective of these tests was to identify panels that would survive the missile impact, strains, accelerations, and contact pressures were not measured. The final documentation on the test data sheet describes the photographs, video and high speed movies that were obtained as part of the test.

Video and high speed movies record the visual aspects of the impact tests. The video camera records every impact test in "real time," while the high speed movic camera records the impact in extremely slow motion. The 16-mm high speed camera, called a Fastax camera, operates at 18,000 frames per minute (a shutter speed of 1/3000 sec.). Minute details of missile/barrier interaction during the impact can be observed in the high speed films.

\subsubsection{Quality Assurance}

A pre-planned program of quality assurance (QA) was developed as part of the test program. Great care was taken in the construction of the concrete and masonry panels. Where applicable, ASTM test procedures were followed to obtain the material 
properties. The panels were carefully mounted on the reaction frame to assure uniform support around all four sides of the test specimen. The timing system used to measure the impact velocity of the missile was calibrated prior to conducting the test series. Each experiment was meticulously recorded in the form of physical measurements, photographs, videos, and highspeed movies. All tests were witnessed and certified by the laboratory supervisor. A general certification of the test data is found in Appendix C.

\subsection{Test Results}

Fourteen impact tests were conducted on the twelve different test panels. Careful examination of each test panel revealed the extent of damage and the panel's resistance to impact. The effects of the various rebar patterns in the reinforced concrete panels were noted. From results of these tests, those panel configurations that satisfy the missile criteria of DOE STD 1020-94 are identified. These panel recommendations are presented in Section 4.7.

\subsubsection{6-In. Reinforced Concrete Slabs}

Three 6-in. reinforced concrete panels were designed and constructed to resist the 35 mph vertical impact speed of the steel pipe missiles specified by DOE STD 1020-94 . In addition, each slab contained a different reinforcing arrangement to determine the effect, if any, on impact resistance.

All three slabs successfully withstood the impact of the pipe missile traveling at approximately $36 \mathrm{mph}$. The missile struck near the center of each panel at a point between the reinforcing bars. The back face of each panel remained intact with no 
scabbing. Only minor damage was inflicted on the slabs. Radical cracks were observed on the back of the panel. Figures 4.12 through 4.17 show the results of the impact tests on the 6-in. concrete panels.

Minor damage included pipe penetration of the front faces Panel RC-6.1, with reinforcement 1.5 in. from the front face, had a 0.25 -in. depth of missile penetration. The other two panels, which had their reinforcement 1.5 in. from the back face, both had a 0.38-in. depth of penetration on the front face.

All three panels had radial tensile cracks on their back face. Not all of the radial cracks propagated through the panel thickness. The vertical and horizontal cracks tended to pass completely through the panel thickness. Crack propagation was determined by tracing the crack continuously from front face to the back face. The fact that CR-6.1 had a larger tensile cracks than the other two panels could be due to the reinforcement being placed near the front face in CR-6.1. Since the concrete had no steel near the back face, the impact caused larger cracks on the back face of CR-6.1, as opposed to the other two panels that did not have steel near the back face. The closer spacing of smaller bars in CR-6.3 (\#3's, 6 in. o.c.) did not appear to make a difference in crack pattern when compared to CR-6.2(\#4's,12 in. o.c). The percent steel in the two slabs was the same.

\subsubsection{Eight -In. Reinforced Concrete Panels}

Three 8-in. reinforced concrete panels were designed and constructed to resist the $50 \mathrm{mph}$ impact of the steel pipe missile as required by DOE STD 1020-94. Each 8-in. panel had different rebar bar patterns. 

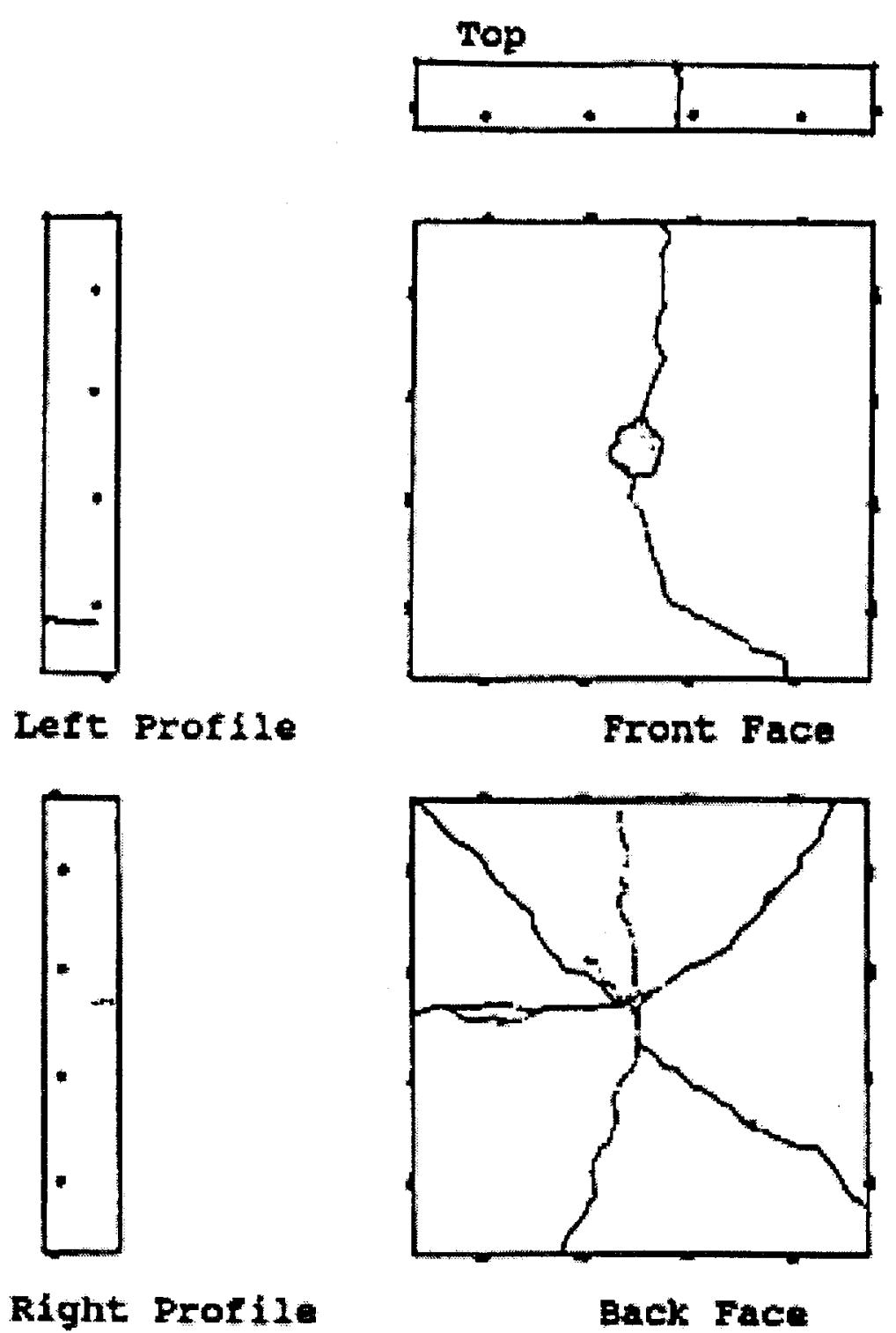

\begin{tabular}{|c|c|l|}
\hline \multicolumn{1}{|c|}{$\begin{array}{c}\text { Barrier } \\
\text { Description }\end{array}$} & $\begin{array}{c}\text { Missile } \\
\text { Speed (mph) }\end{array}$ & Barrier Impact Damage \\
\hline $\begin{array}{l}\text { 6-in. slab with \#3's } \\
\text { 9-in. o.c. each way, }\end{array}$ & 35 & $\bullet 0.25$ in. penetration \\
1.5-in. from front face. & & $\begin{array}{l}\text { Radial cracks with a 0.19 } \\
\text { in. maximum width of } \\
\text { cracks } \\
\text { propagated through slab }\end{array}$ \\
\hline
\end{tabular}

FIGURE 4.12 CR-6.1 DATA 


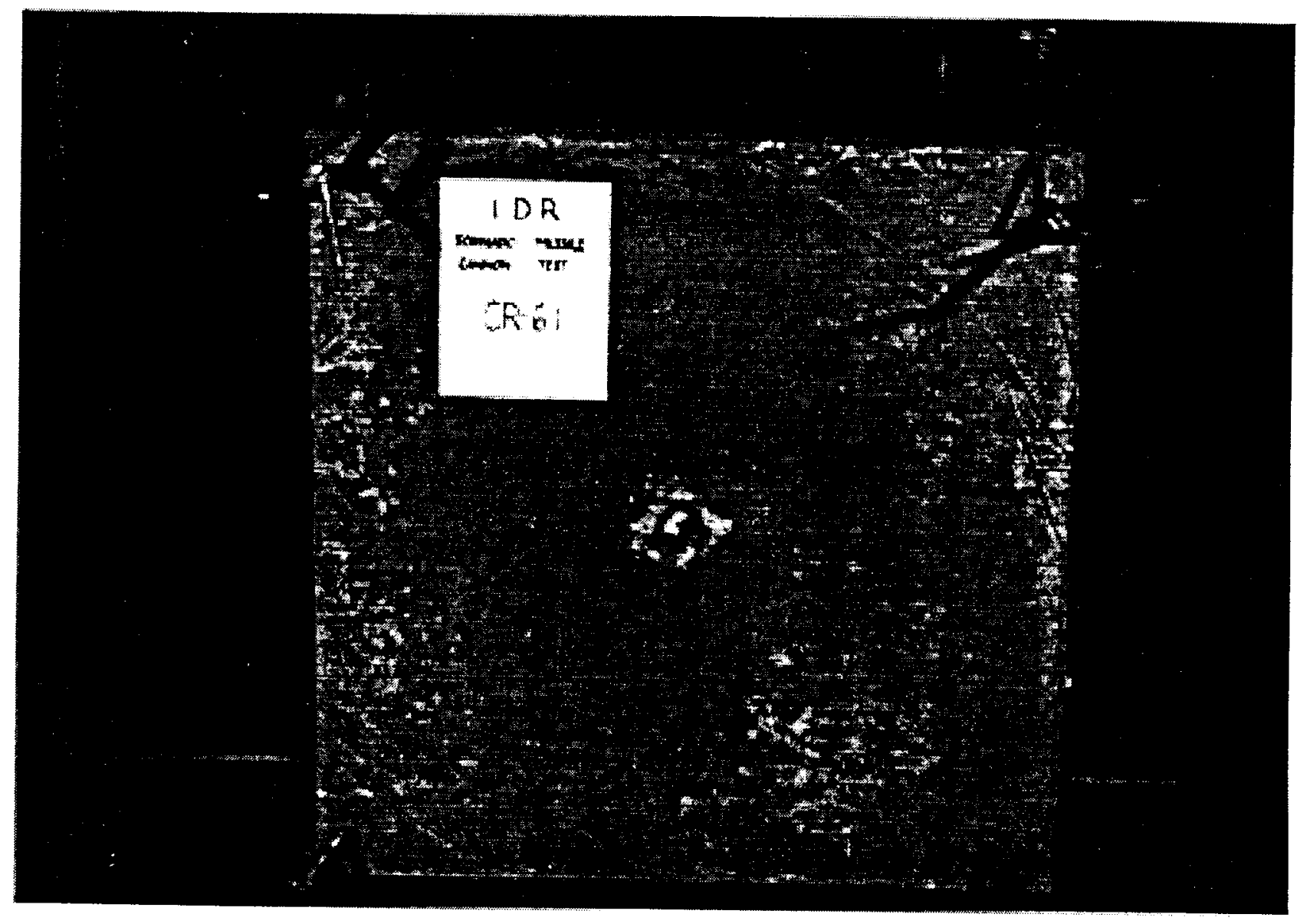

FIGURE 4.13a FRONT FACE OF CR-6.1 


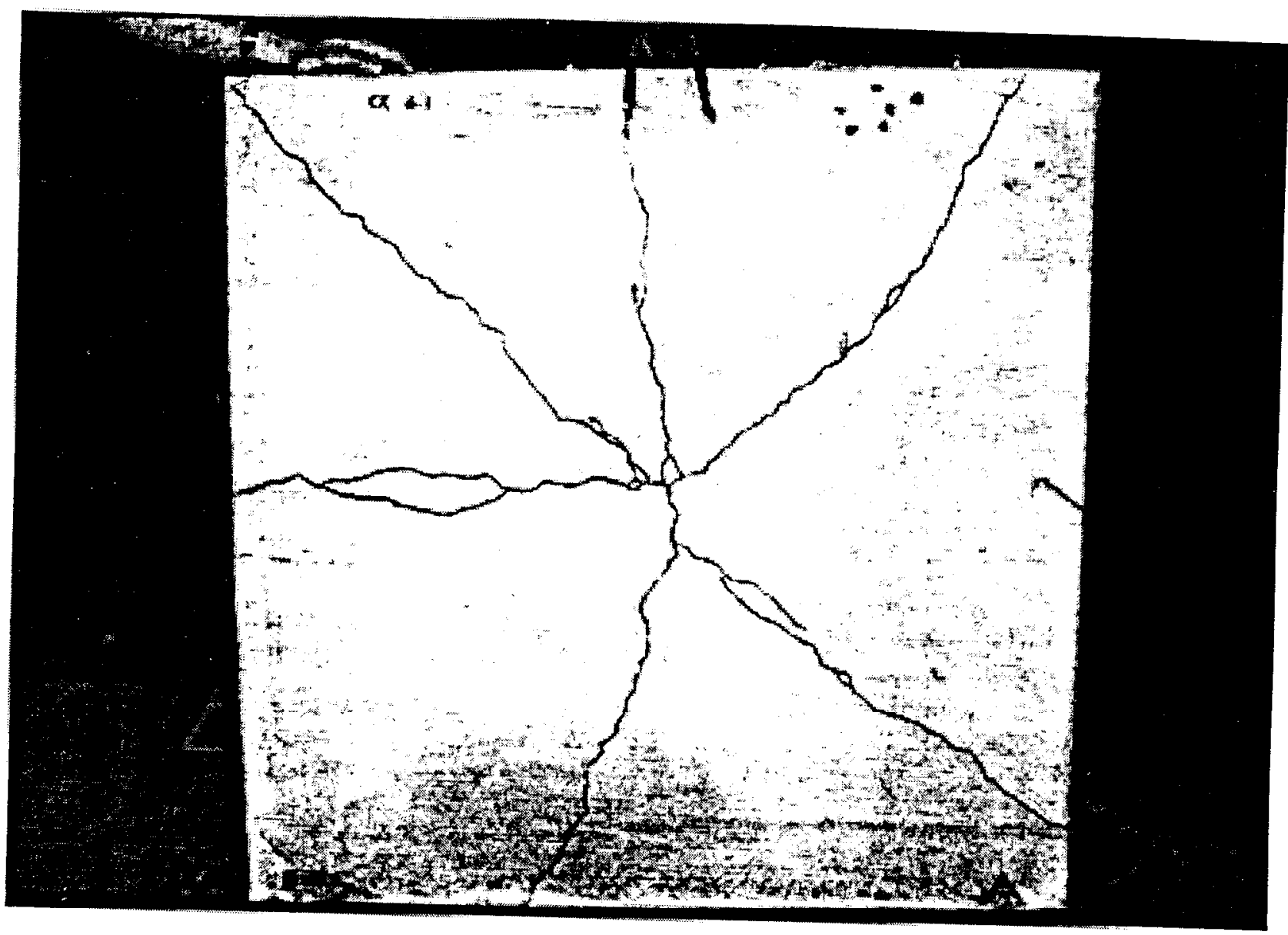

FIGURE 4.13b BACK FACE OF CR-6.1 


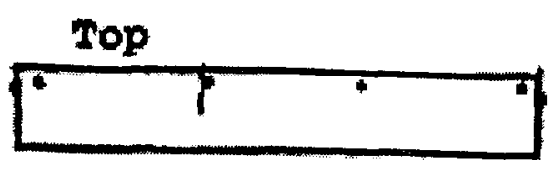

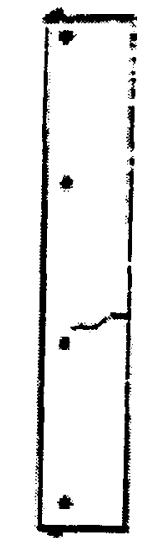

Left Profile

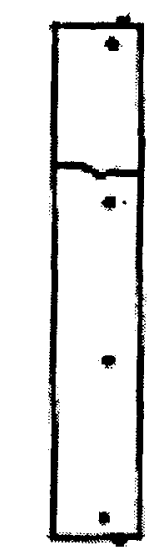

Right Profile

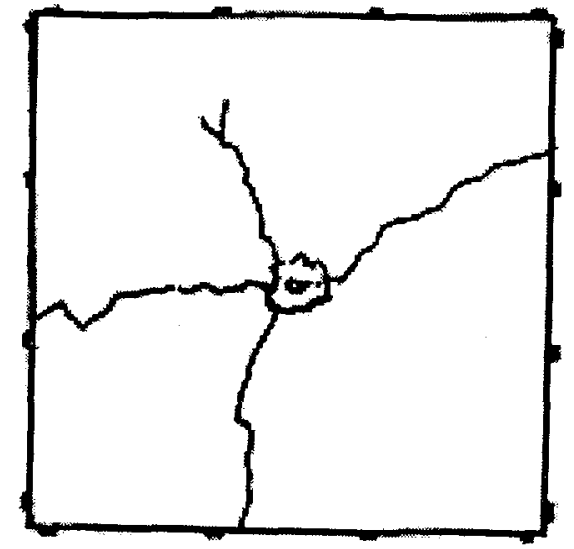

Front Face

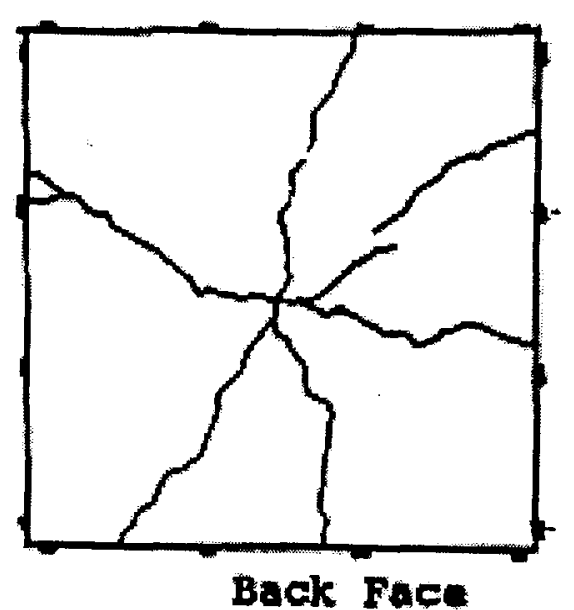

\begin{tabular}{|c|c|c|}
\hline $\begin{array}{c}\text { Barrier } \\
\text { Description }\end{array}$ & $\begin{array}{c}\text { Missile } \\
\text { Speed (mph) }\end{array}$ & Barrier Impact Damage \\
\hline $\begin{array}{l}\text { 6-in. slab with \#4's } \\
12 \text {-in. o.c. each way, } \\
1.5 \text {-in. from back face. }\end{array}$ & 36 & $\begin{array}{l}\text { - } 0.38 \text { in. penetration } \\
\text { - Radial cracks with a } 0.06 \\
\text { in. maximum width of } \\
\text { cracks } \\
\text { propagated through slab }\end{array}$ \\
\hline
\end{tabular}

FIGURE 4.14 CR-6.2 DATA 


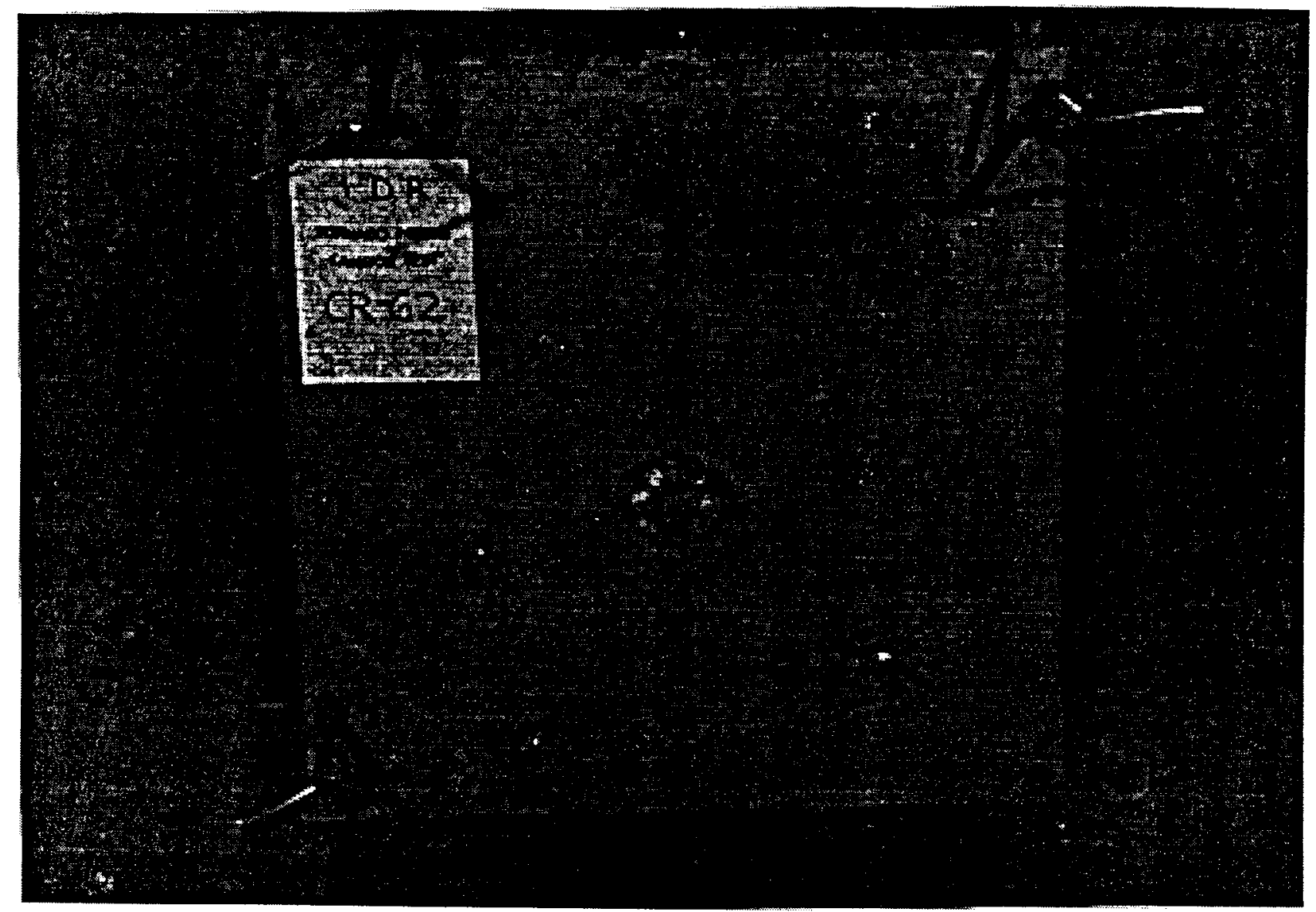

FIGURE 4.15a FRONT FACE OF CR-6.2 


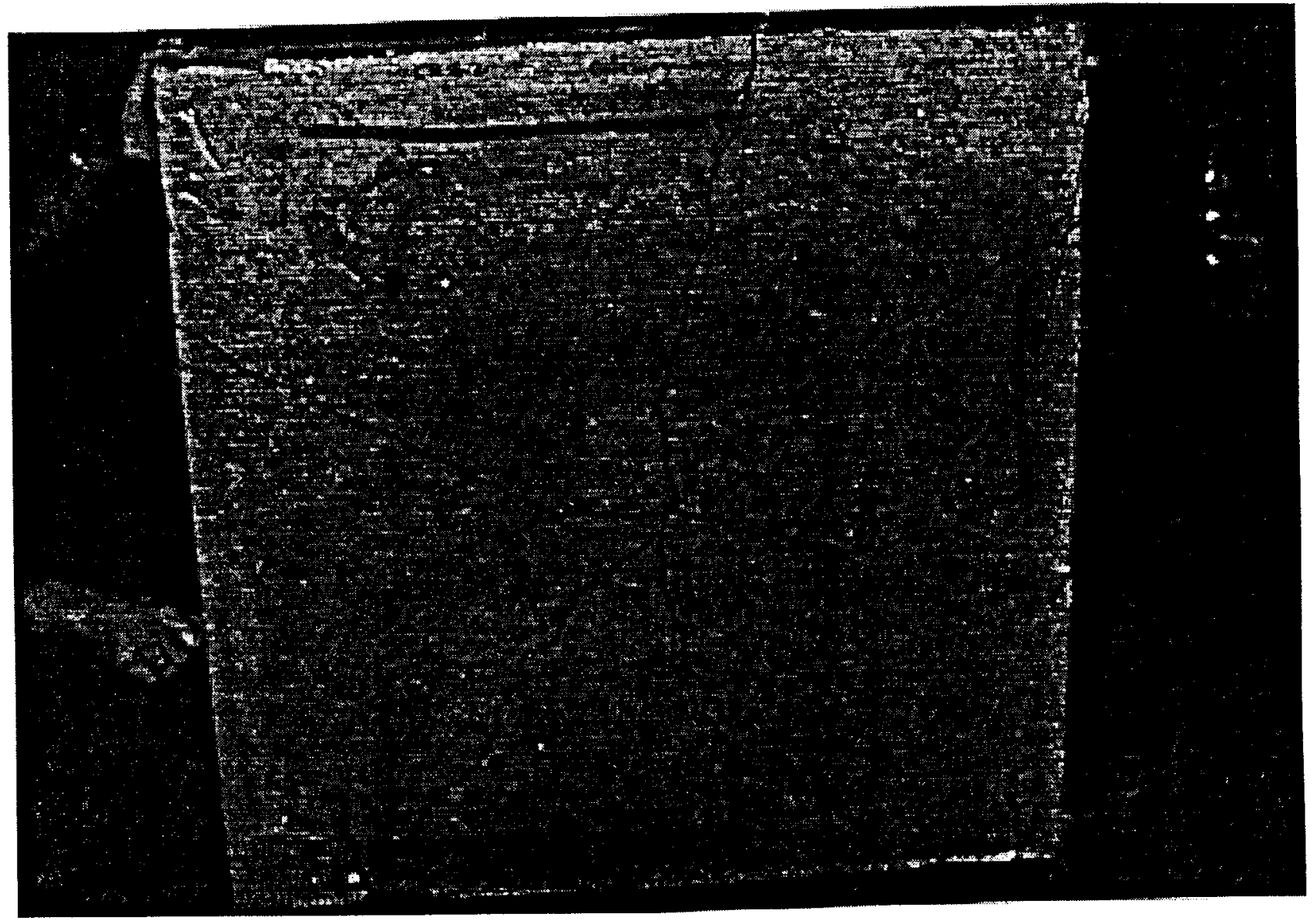

FIGURE 4.15b BACK FACE OF CR-6.2 

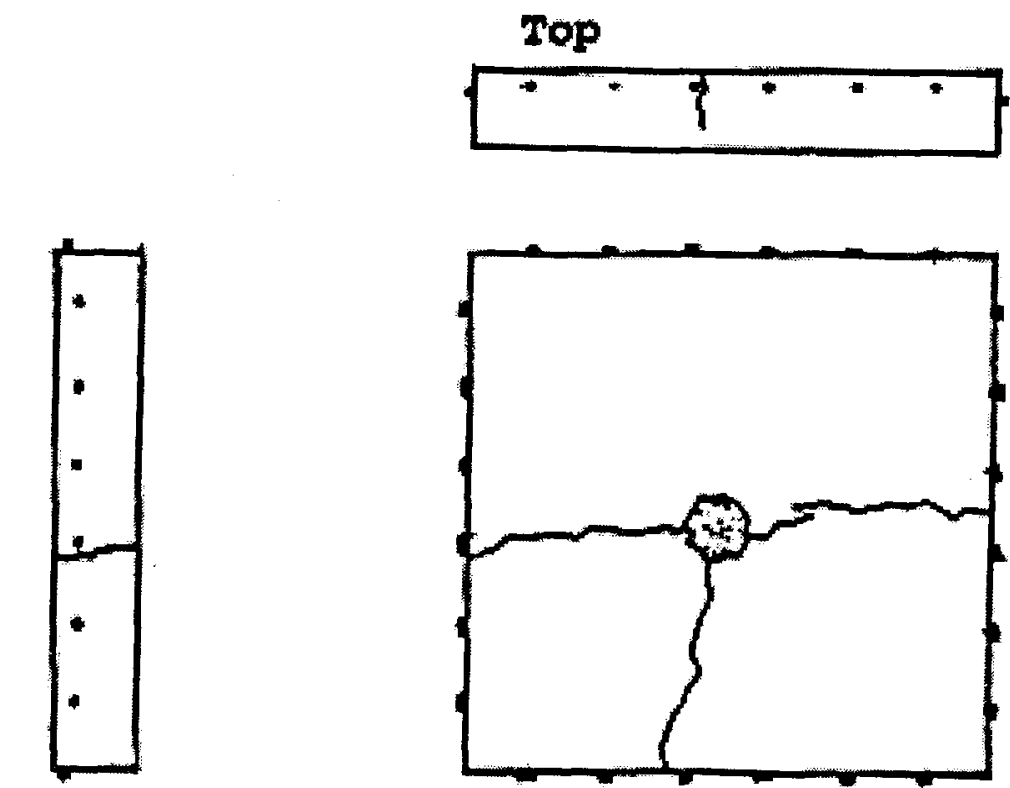

Lete Protile
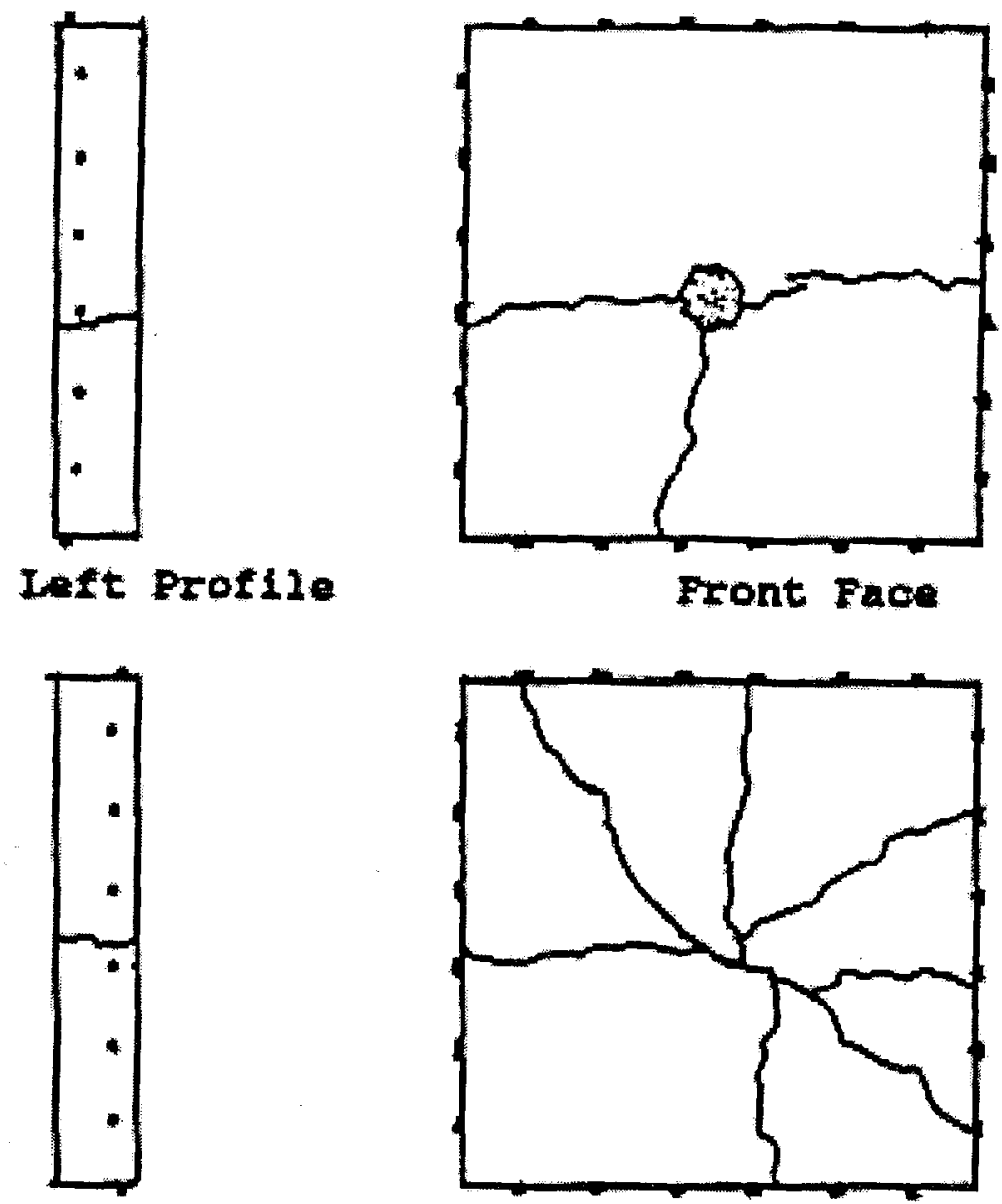

Right Profile

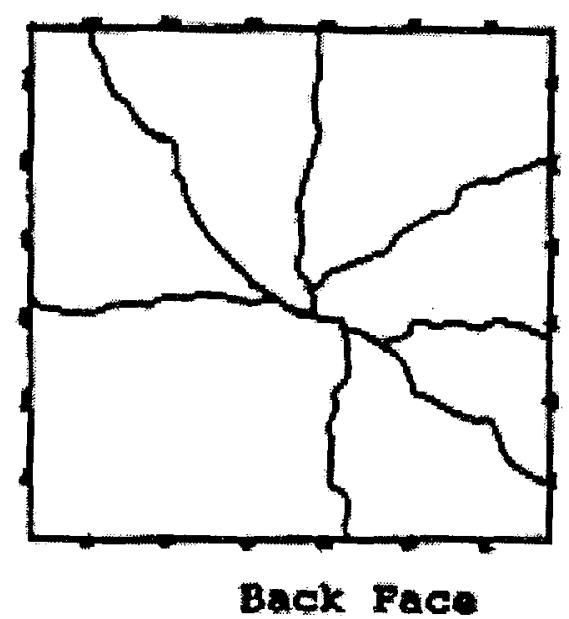

\begin{tabular}{|l|c|l|}
\hline \multicolumn{1}{|c|}{$\begin{array}{c}\text { Barrier } \\
\text { Description }\end{array}$} & $\begin{array}{c}\text { Missile } \\
\text { Speed (mph) }\end{array}$ & Barrier Impact Damage \\
\hline $\begin{array}{l}\text { 6-in. slab with \#3's } \\
\text { 6-in. o.c. each way, }\end{array}$ & 37 & $\bullet 0.38$ in. penetration \\
1.5-in. from back face. & & $\begin{array}{l}\text { Radial cracks with a 0.06 } \\
\text { in. maximum width of } \\
\text { cracks } \\
\text { propagated through slab }\end{array}$ \\
\hline
\end{tabular}

FIGURE 4.16 CR-6.3 DATA 


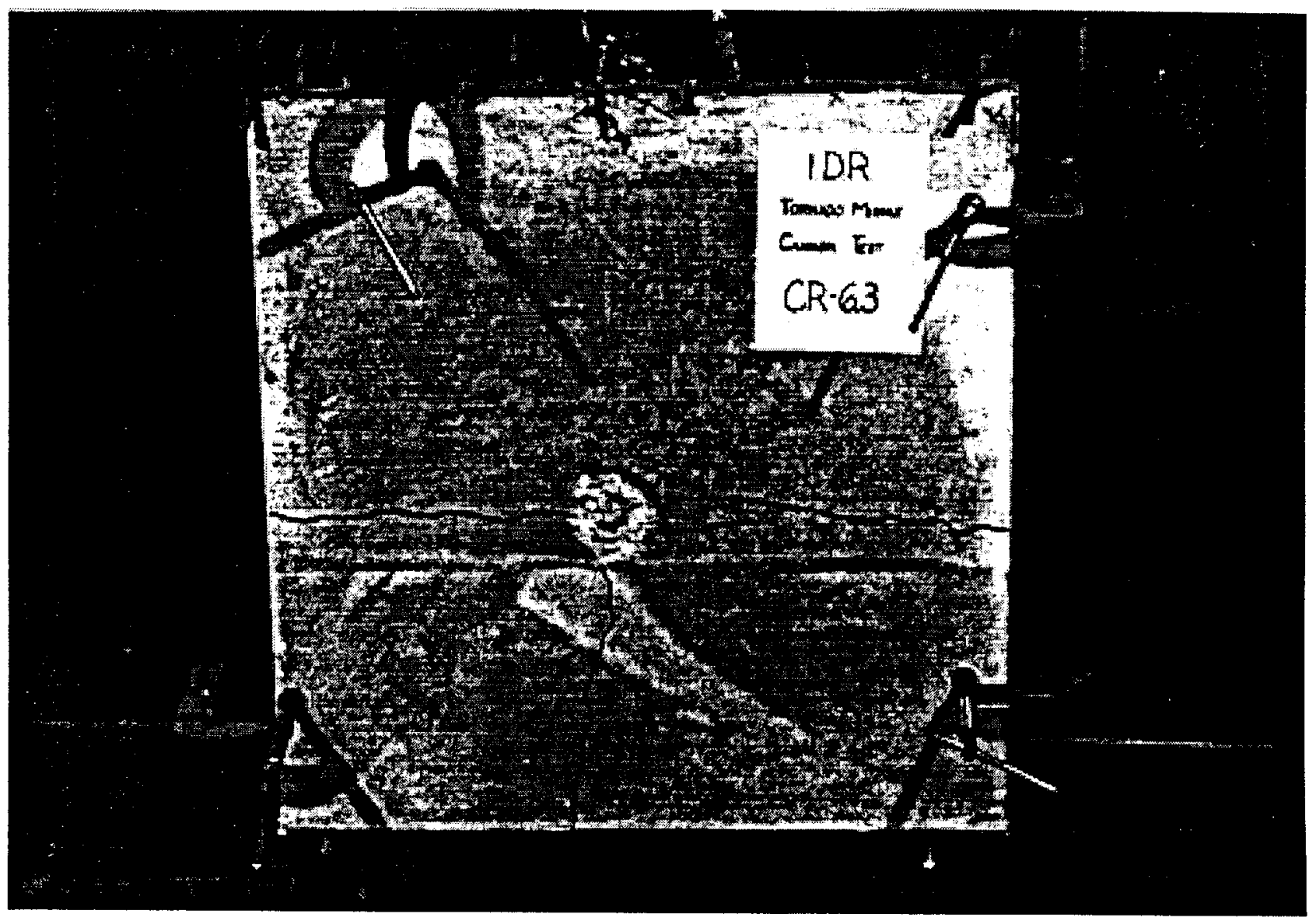

FIGURE 4.17a. FRONT FACE OF CR-6.3 


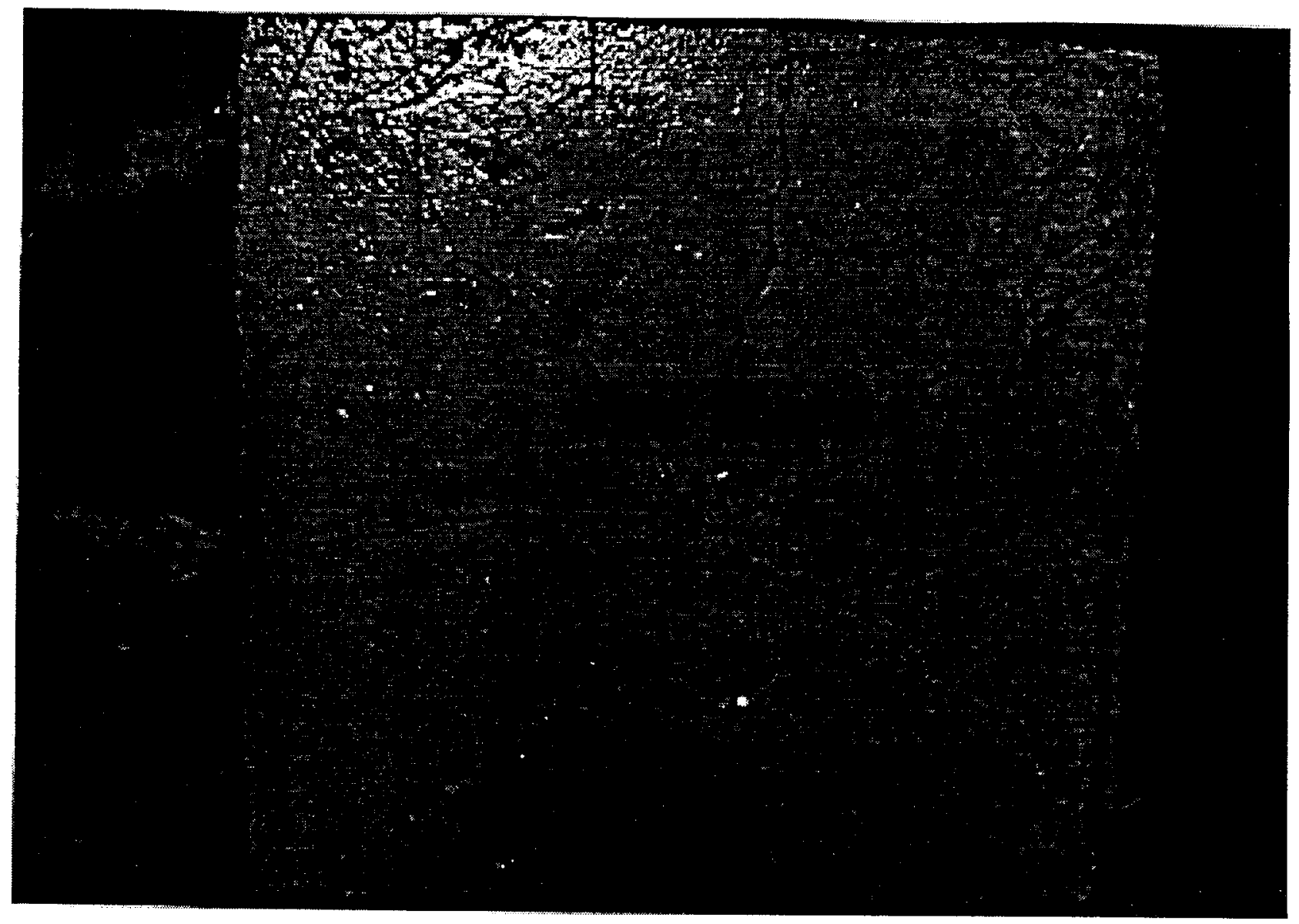

FIGURE 4.17b. BACK FACE OF CR-6.3 
All three 8-in. panels successfully resisted impact of the pipe missiles without back face scabbing. The impact speed of the first two panels tested fell slightly below the targeted speed of $50 \mathrm{mph}$. Panel RC-8.3 was impacted at a slightly larger speed (50 mph) than other two (44 mph). The results of the missile impacts on the 8-in. panels are shown in Figures 4.18 through 4.23. Each panel exhibited a penetration crater on the front face. Radial cracks were found on the back face of each panel due to tensile stresses set up in the panels. These cracks propagated through the thicknesses of panels CR-8.1 and CR8.2, but cracking in CR-8.3 only propagated three quarters of the way through its thickness because of the reinforcing near the front face. The maximum crack width was about the same in all three panels.

CR-8.1 appeared to resist impact slightly better than CR-8.2 because of the closer steel spacing. CR-8.3 (reinforcement placed 1.5 in. from each face) had a larger penetration depth but no cracks on the front face. The larger penetration depth was likely due to the higher impact speed. The absence of cracks on the front face was due to the presence of rebar near the front face. Thus, the reinforcing pattern in CR-8.3 appears to be the best of the three.

\subsubsection{Nine-In. Reinforced Concrete Panels}

The 9-in. (Figure 4.24) panel was first impacted at $50 \mathrm{mph}(\mathrm{CR}-9.1)$ in order to compare results with the 8-in. panel (CR-8.3). At $50 \mathrm{mph}$, the impact on CR-9.1 produced a 0.44 in. penetration on the front face and hairline radial tensile cracks on the back face that only propagated halfway through thickness. With this small amount damage, it was decided the impact the 9-in. panel a second time at $75 \mathrm{mph}$. 


\section{Top}
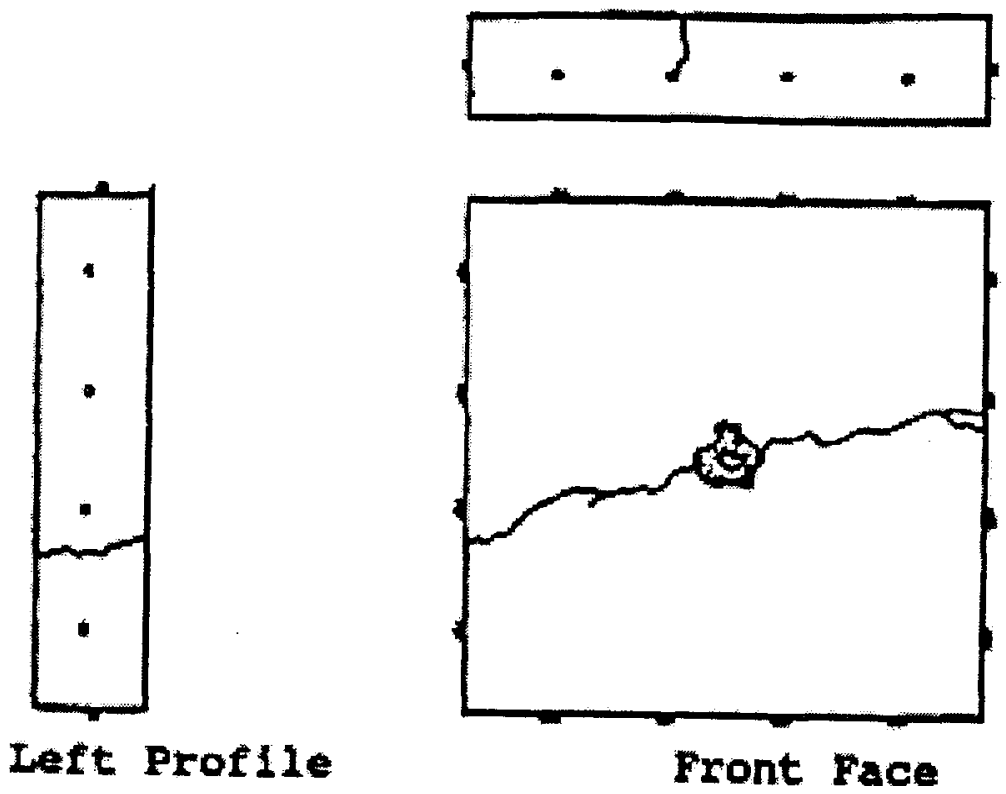

Left Profile
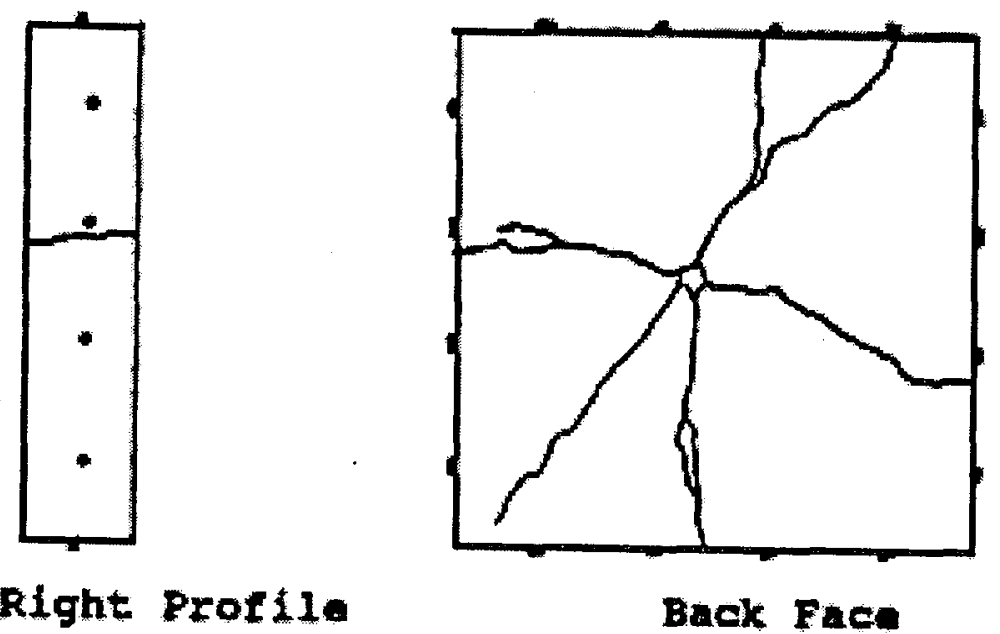

Right Profila

Back Face

\begin{tabular}{|l|c|l|}
\hline \multicolumn{1}{|c|}{$\begin{array}{c}\text { Barrier } \\
\text { Description }\end{array}$} & $\begin{array}{c}\text { Missile } \\
\text { Speed (mph) }\end{array}$ & Barrier Impact Damage \\
\hline $\begin{array}{l}\text { 8-in. slab with \#4's } \\
\text { 9-in. o.c. each way, placed } \\
\text { in the middle of slab. }\end{array}$ & 44 & $\bullet 0.38$ in. penetration \\
& & $\begin{array}{l}\text { Radial cracks with a 0.06 } \\
\text { in. maximum width of } \\
\text { cracks } \\
\text { propagated through slab }\end{array}$ \\
\hline
\end{tabular}

FIGURE 4.18 CR-8.1 DATA 


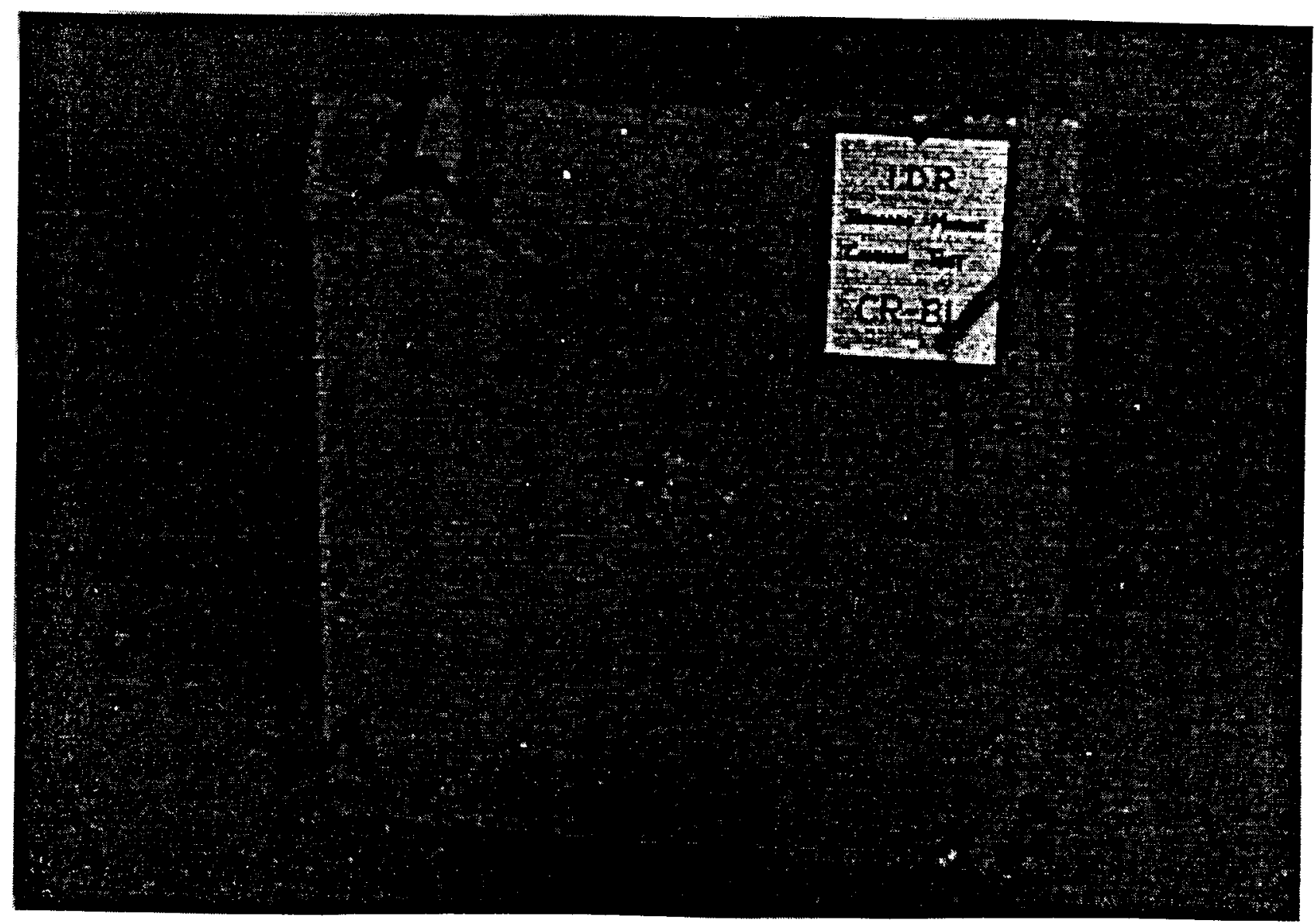

FIGURE 4.19a. FRONT FACE OF CR-8.1 


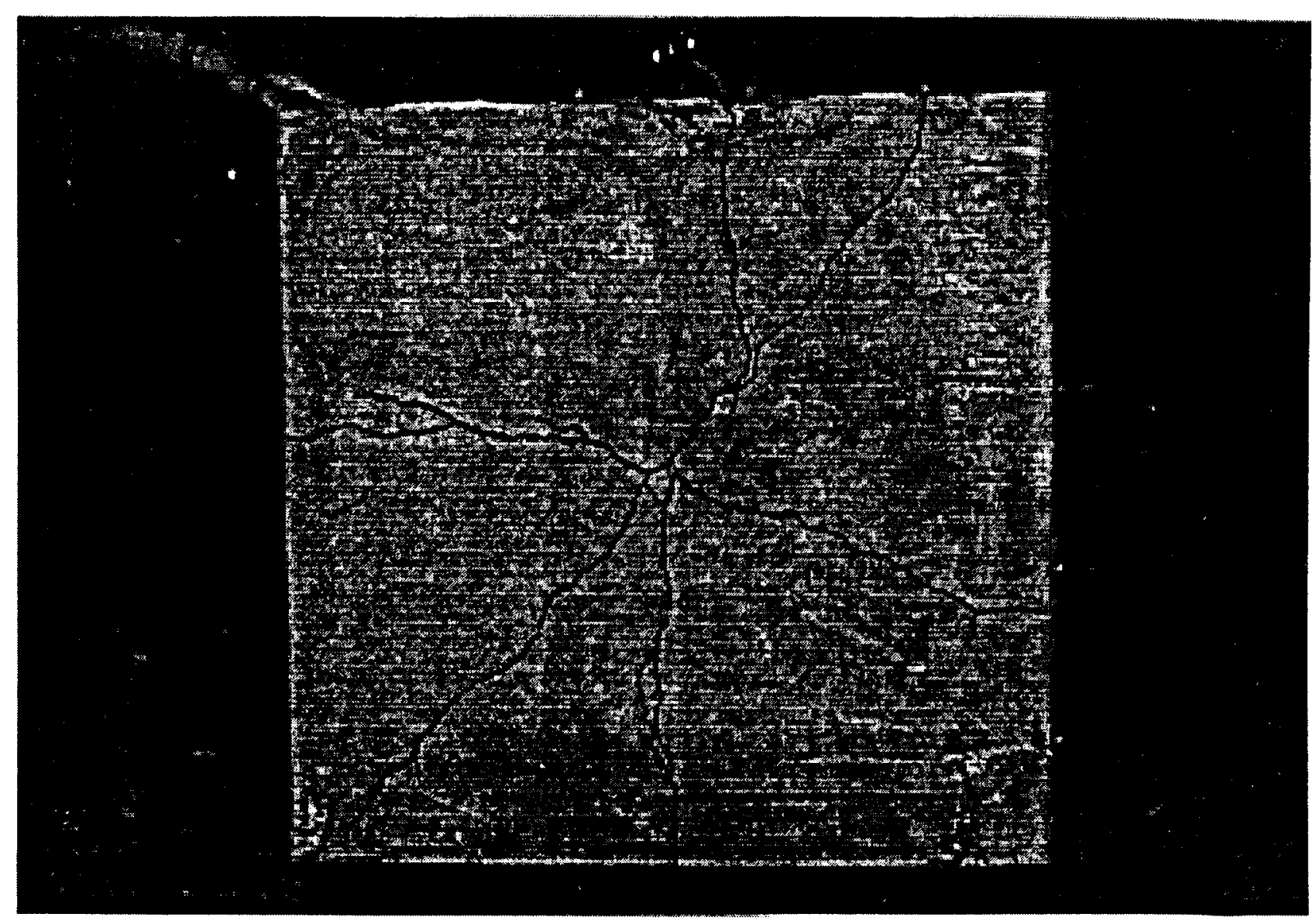

\section{FIGURE 4.19b BACK FACE OF CR-8.1}



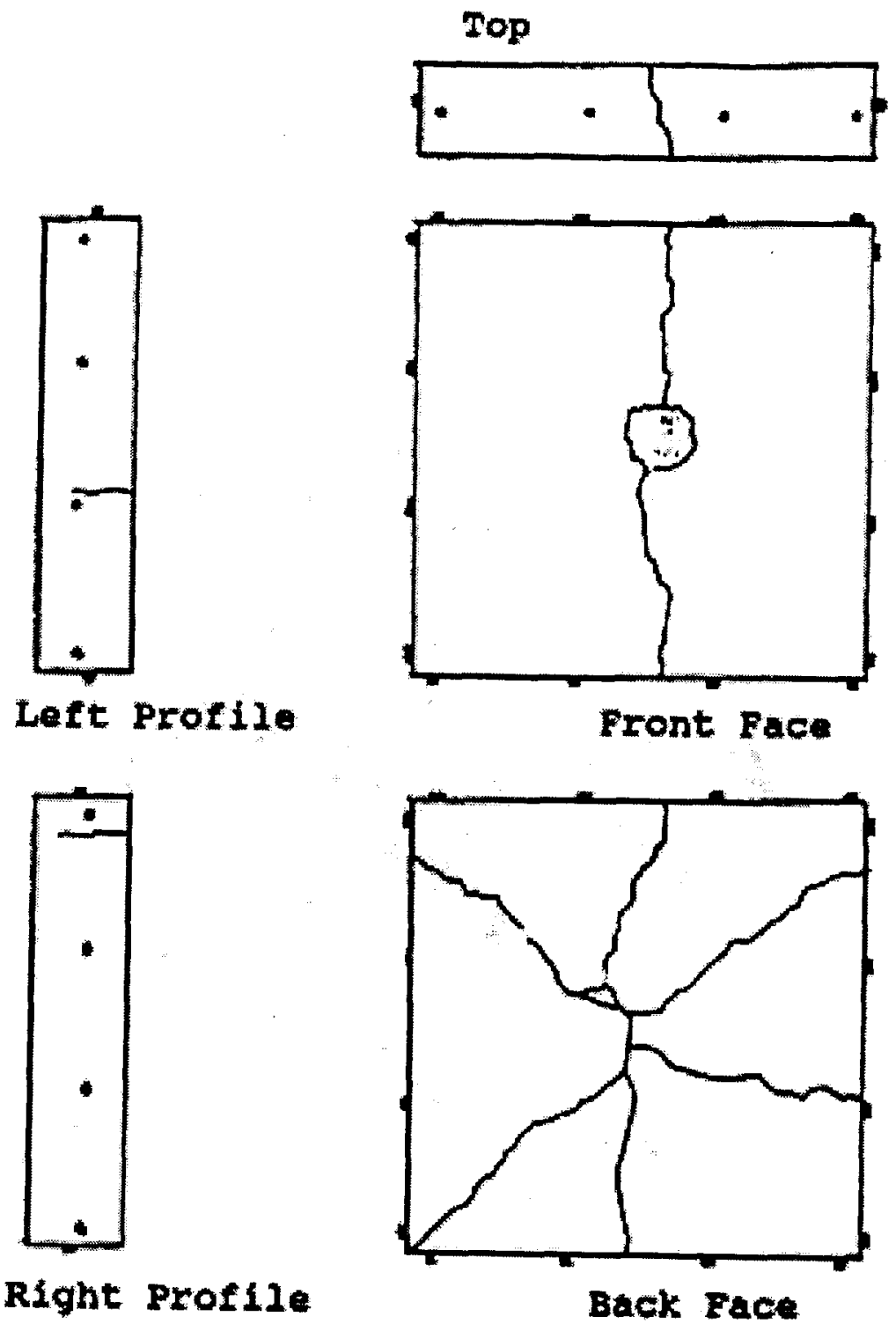

\begin{tabular}{|l|c|l|}
\hline \multicolumn{1}{|c|}{$\begin{array}{c}\text { Barrier } \\
\text { Description }\end{array}$} & $\begin{array}{c}\text { Missile } \\
\text { Speed (mph) }\end{array}$ & Barrier Impact Damage \\
\hline $\begin{array}{l}\text { 8-in. slab with \#4's } \\
\text { 12-in. o.c. each way, } \\
\text { placed } \\
\text { in the middle of slab. }\end{array}$ & 44 & $\bullet 0.63$ in. penetration \\
& & $\begin{array}{l}\text { Radial cracks with a 0.06 } \\
\text { in. maximum width of } \\
\text { cracks } \\
\text { propagated through slab }\end{array}$ \\
\hline
\end{tabular}

FIGURE 4.20 CR-8.2 DATA 


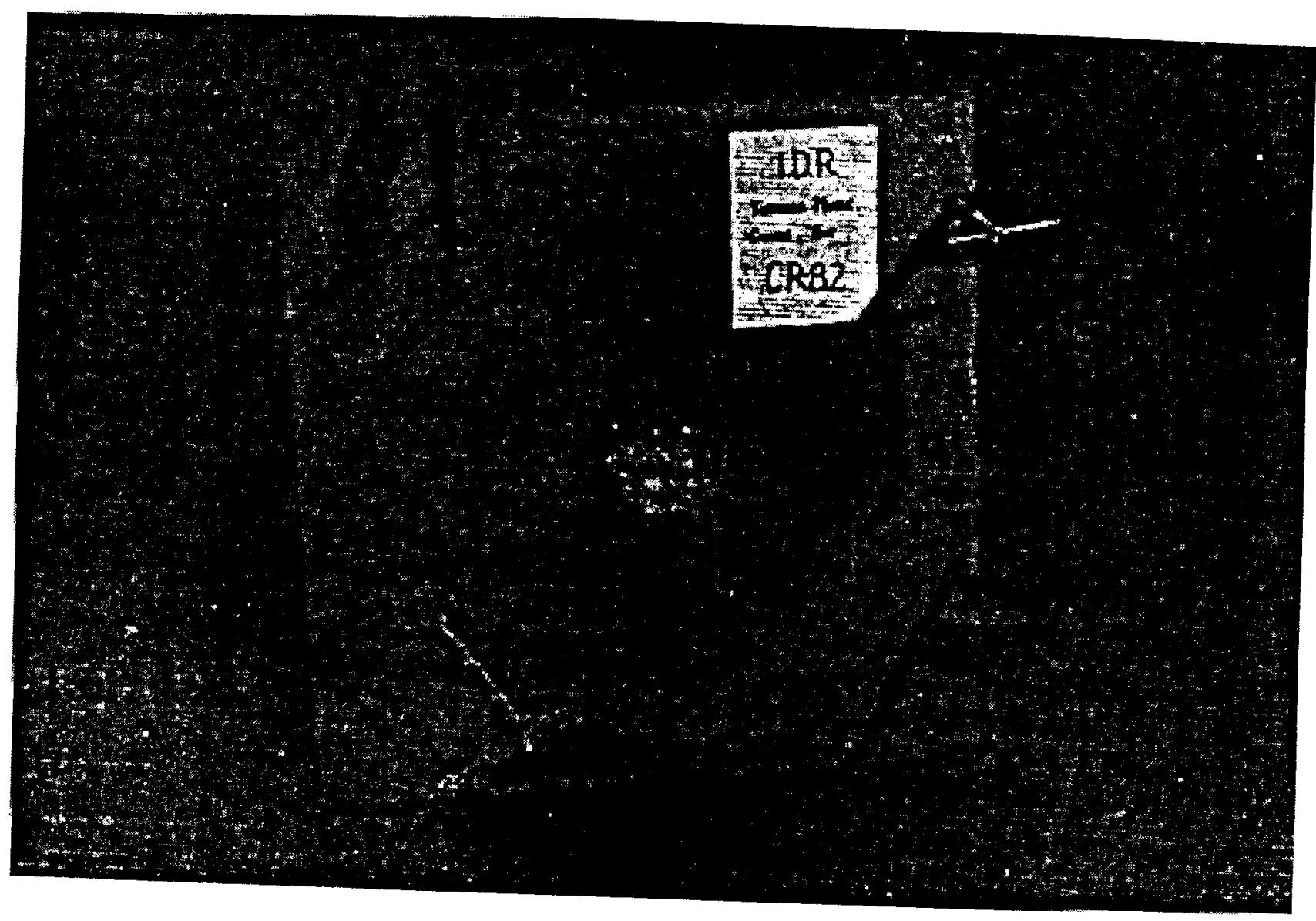

FIGURE 4.21a. FRONT FACE OF CR-8.2 


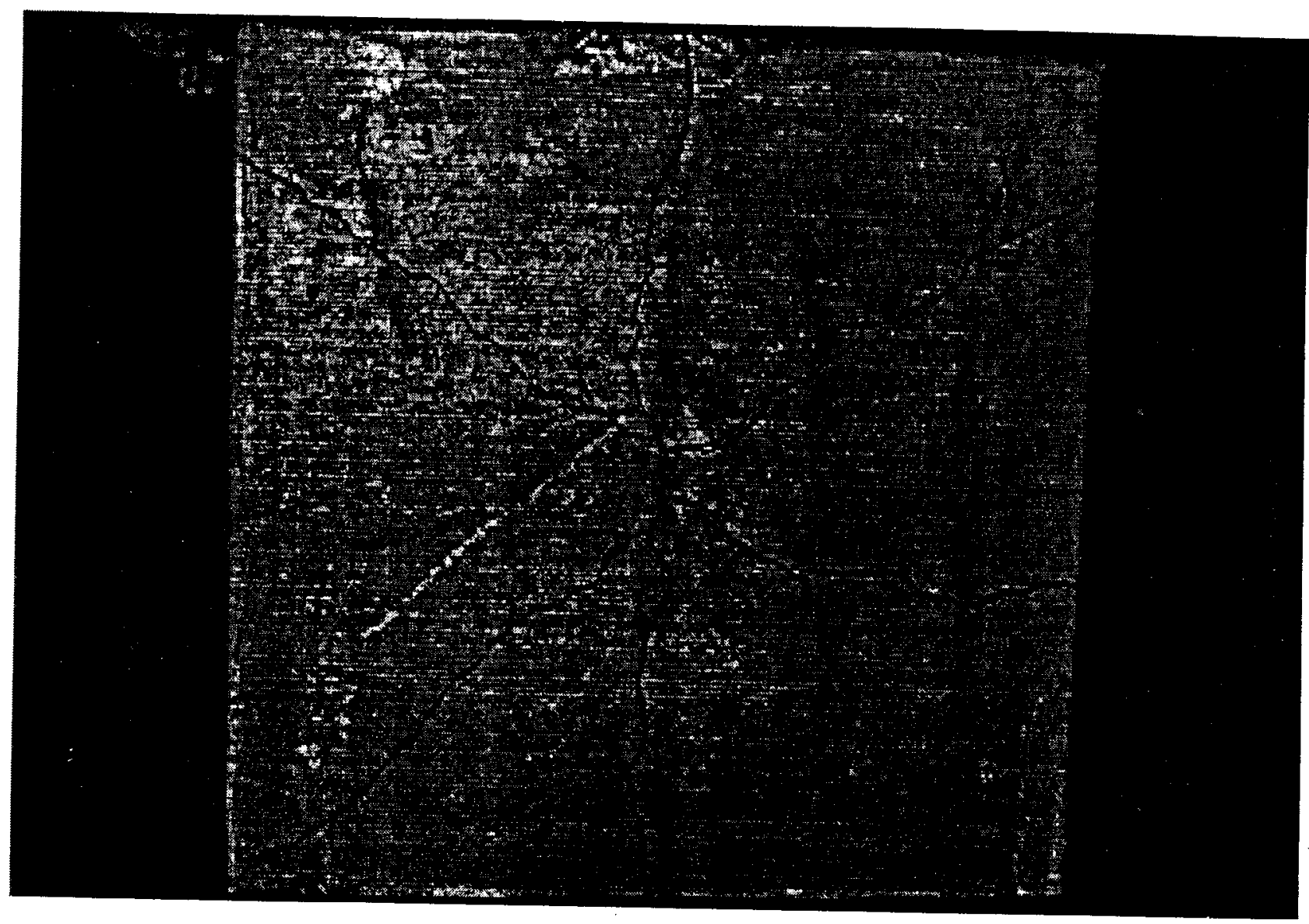

\section{FIGURE 4.21b BACK FACE OF CR-8.2}




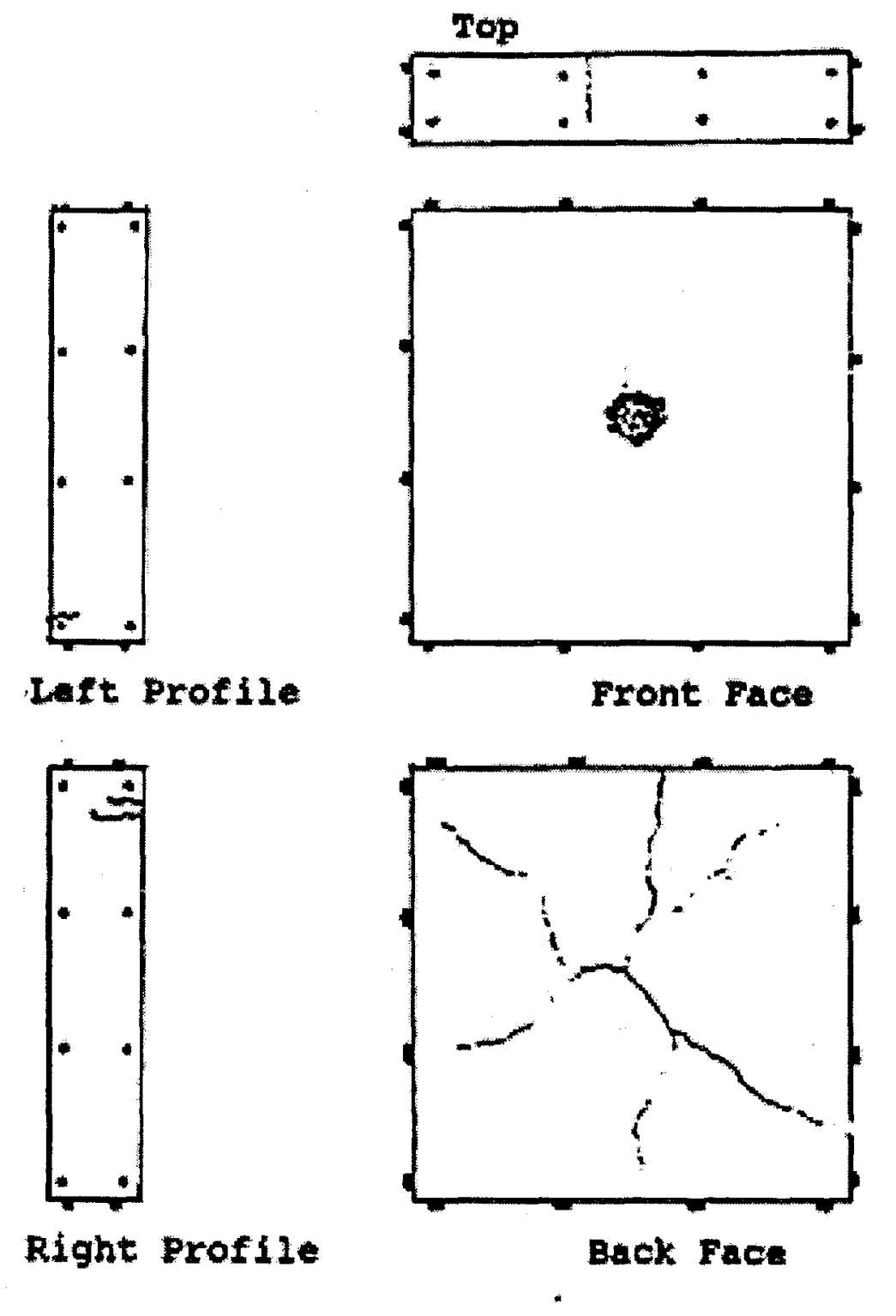

\begin{tabular}{|c|c|c|}
\hline $\begin{array}{c}\text { Barrier } \\
\text { Description }\end{array}$ & $\begin{array}{c}\text { Missile } \\
\text { Speed (mph) }\end{array}$ & Barrier Impact Damage \\
\hline $\begin{array}{l}8 \text {-in. slab with \#3's } \\
12 \text {-in. o.c. each way, placed } \\
1.5 \text {-in. from each face. }\end{array}$ & 50 & $\begin{array}{l}\text { - } 0.69 \text { in. penetration } \\
\text { - Radial cracks with a } 0.09 \\
\text { in. maximum width of } \\
\text { cracks } \\
\text { propagated through } 3 / 4 \text { of } \\
\text { slab width }\end{array}$ \\
\hline
\end{tabular}

\section{FIGURE 4.22 CR-8.3 DATA}




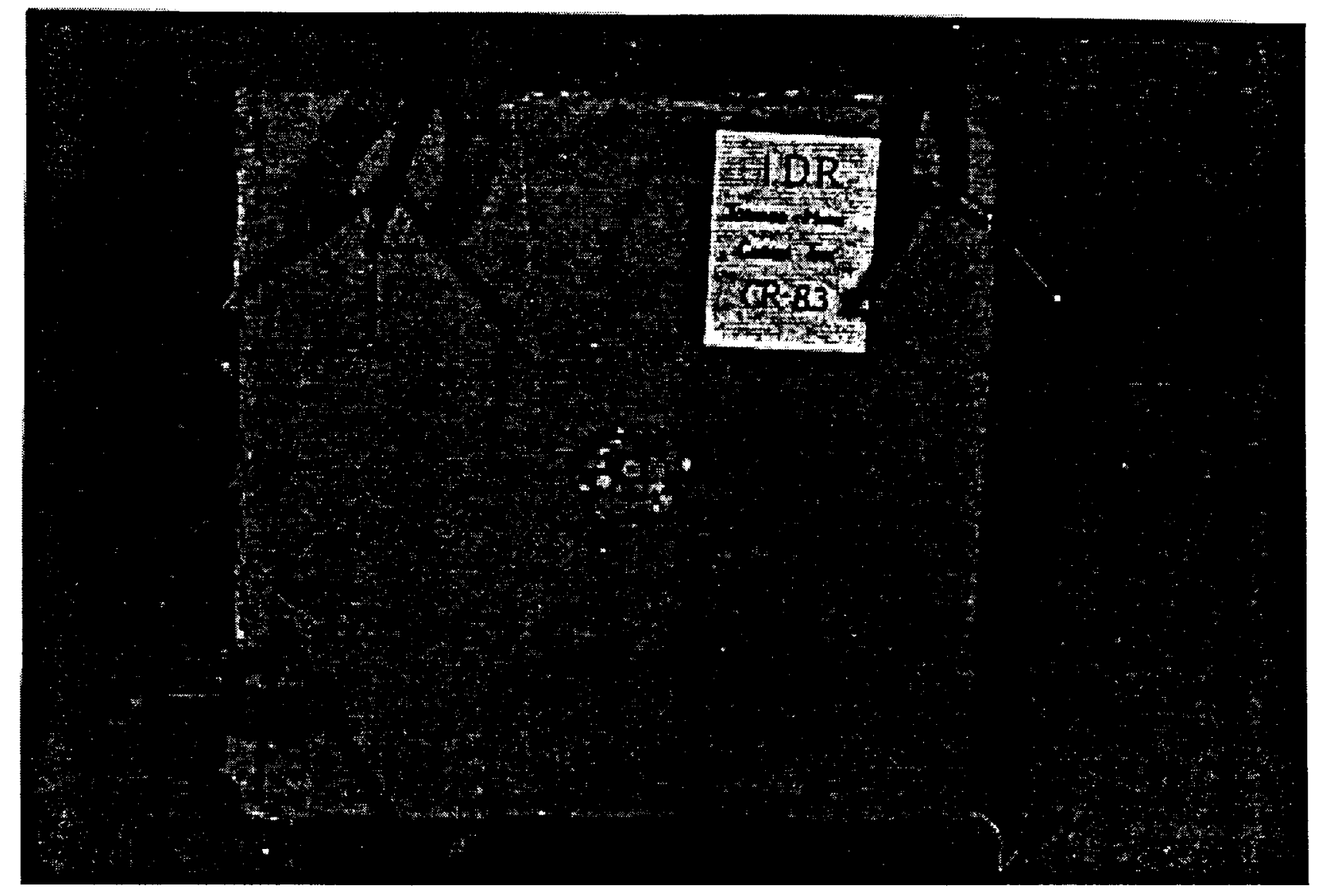

FIGURE 4.23a FRONT FACE OF CR-8.3 


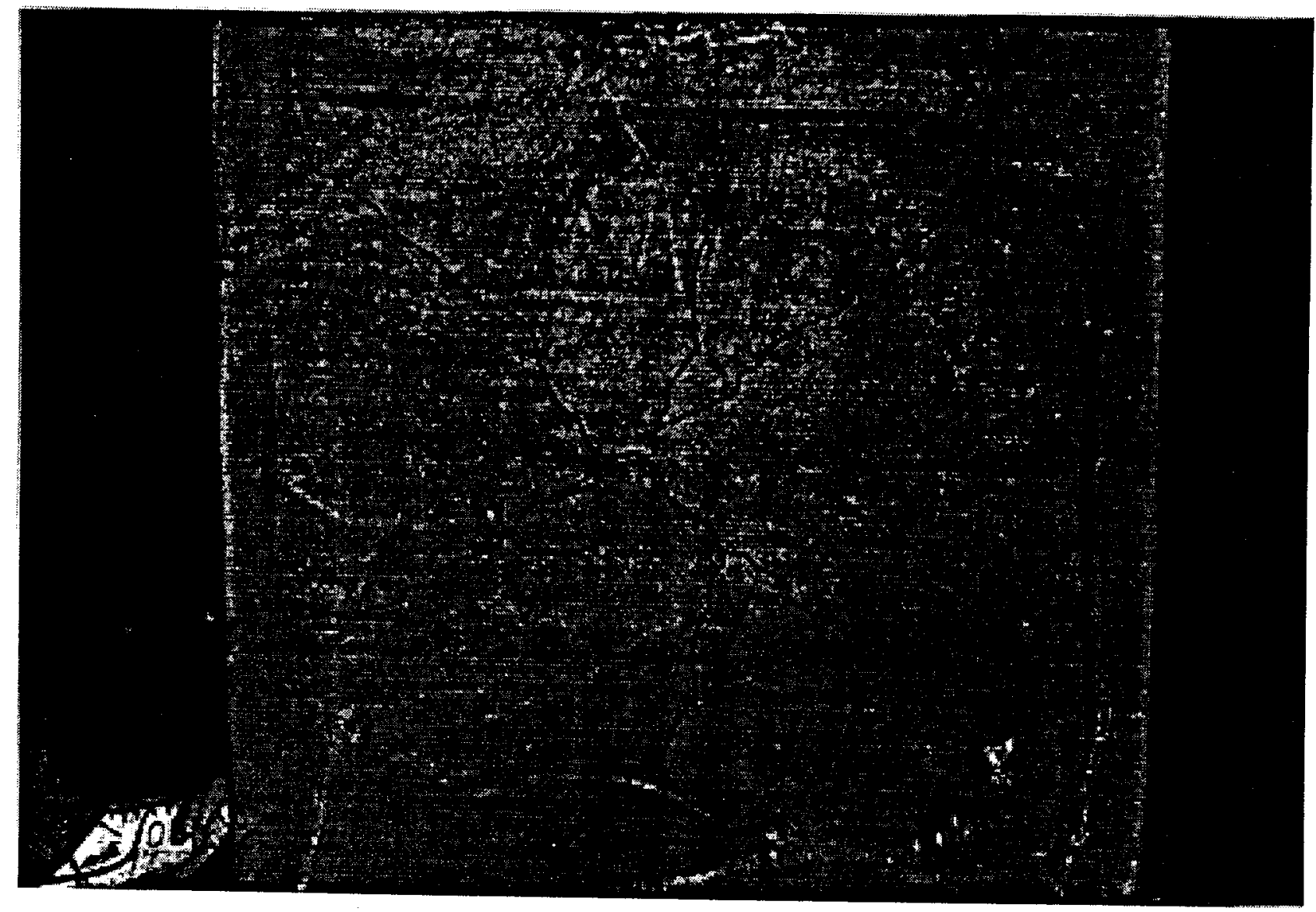

\section{FIGURE 4.23b BACK FACE OF CR-8.3}


The 9-in. panel was impacted again at the same location at a speed of $78 \mathrm{mph}$ (RC-9.2). The penetration depth increased to $1.50 \mathrm{in}$. and radial cracks increased to a point where several scabbing fragments with dimensions of $1.00 \mathrm{in.}$ by $0.5 \mathrm{in}$. ejected from the back face. This second impact at $78 \mathrm{mph}$ was judged to be very near the threshold speed for back face scabbing.

A single impact test, CR-10.1, was performed on the 10-in. panel (see Figures 4.27,4.28a and 4.28b), which resulted in no back face scabbing. The pipe, at a speed of $74 \mathrm{mph}$, hit the panel $4.5 \mathrm{in}$. to the right of center. The missile penetrated $0.81 \mathrm{in}$. and produced hairline cracks on the back face. The cracks perforated through less than half the thickness.

Thus, both the 9-in. and 10 in. panels successfully resisted the $75 \mathrm{mph}$ pipe impact. The 10-in. panel performed slightly better than the 9-in., as expected.

\subsubsection{Concrete Reinforcing Patterns}

Some reinforcing arrangements proved to be slightly more effective than others in improving impact resistance. Table 4.6 presents the different arrangements for each panel and the corresponding damage inflicted. The test results suggest that steel reinforcement placed in the middle or back face of the panel appear to be effective in reducing crack width. Reinforcing steel placed at both front face and back face appeared to negate crack propagation. Panels with the closest steel spacing showed signs of improved impact resistance, but results were not conclusive. 


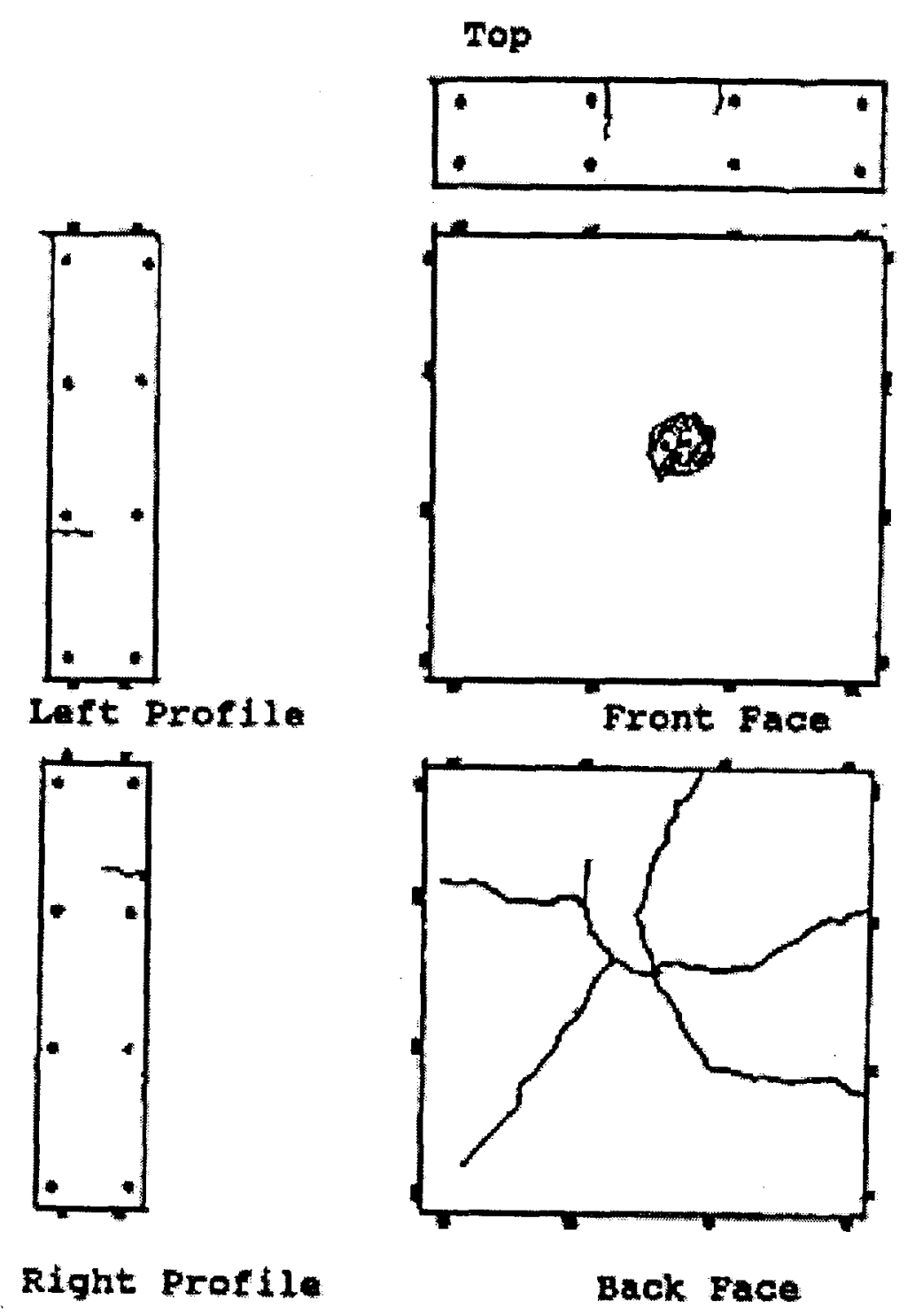

\begin{tabular}{|l|c|l|}
\hline \multicolumn{1}{|c|}{$\begin{array}{c}\text { Barrier } \\
\text { Description }\end{array}$} & $\begin{array}{c}\text { Missile } \\
\text { Specd (mph) }\end{array}$ & Barrier Impact Damage \\
\hline $\begin{array}{l}\text { 9-in. slab with \#4's } \\
\text { 12-in. o.c. each way, placed } \\
\text { 1.5-in. from each face. }\end{array}$ & 50 & $\bullet 0.44$ in. penetration \\
& & $\begin{array}{l}\text { Hairline radial cracks } \\
\text { propagating through half } \\
\text { the slab thickness }\end{array}$ \\
\hline
\end{tabular}

FIGURE 4.24 CR-9.1 (NO PHOTOS AVAILABLE) 

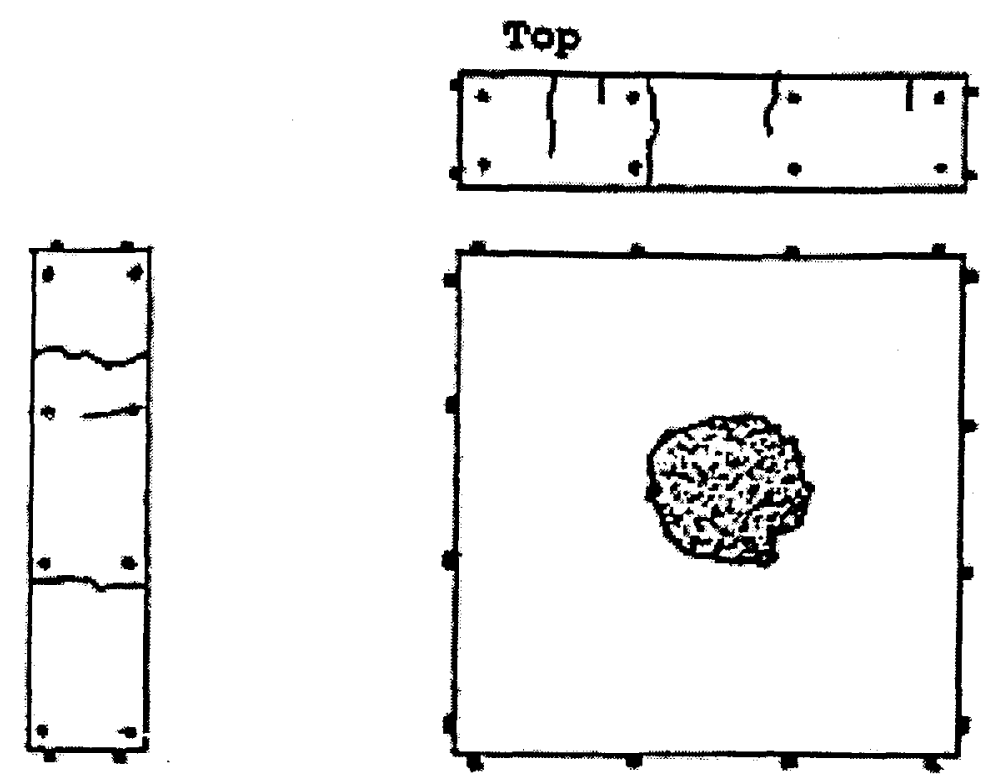

Left Profile
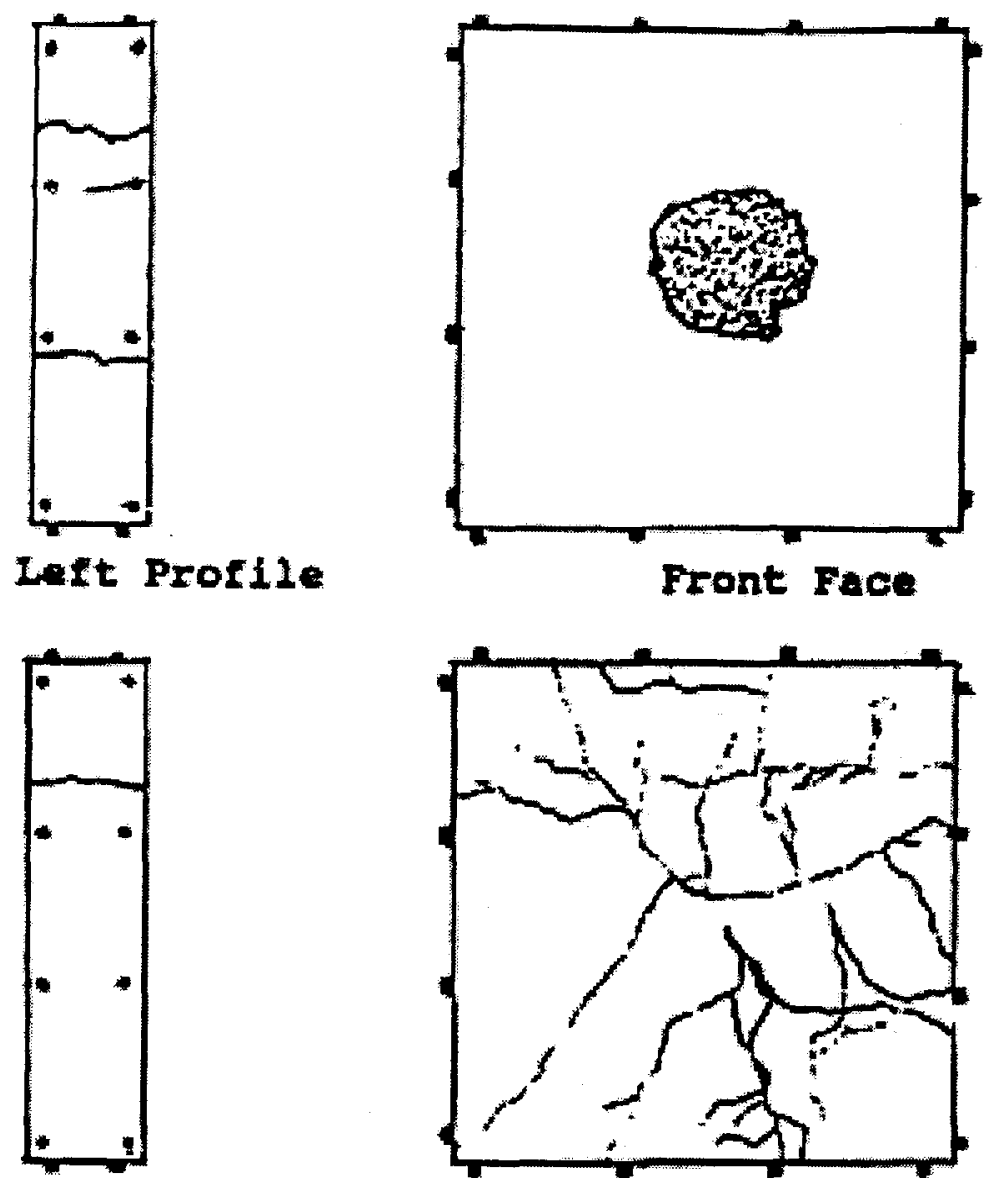

Right Protile

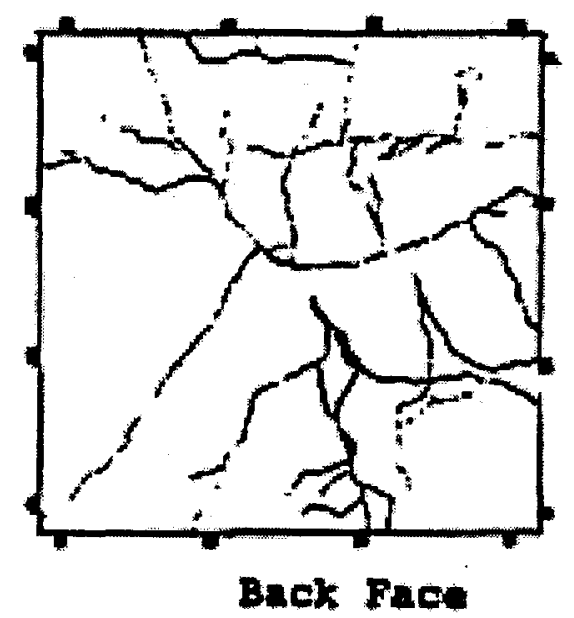

\begin{tabular}{|l|c|c|}
\hline \multicolumn{1}{|c|}{$\begin{array}{c}\text { Barrier } \\
\text { Description }\end{array}$} & $\begin{array}{c}\text { Missile } \\
\text { Speed (mph) }\end{array}$ & Barrier Impact Damage \\
\hline $\begin{array}{l}\text { 9-in. slab with \#4's } \\
\text { 12-in. o.c. each way, placed } \\
\text { 1.5-in. from each face. }\end{array}$ & 78 & $\bullet 1.5$ in. penetration \\
& & $\begin{array}{l}\text { Radial cracks with scabbing, } \\
\text { scab fragments had } \\
\text { dimensions of (1.0x0.5)-in. }\end{array}$ \\
\hline
\end{tabular}

\section{FIGURE 4.25 CR-9.2}




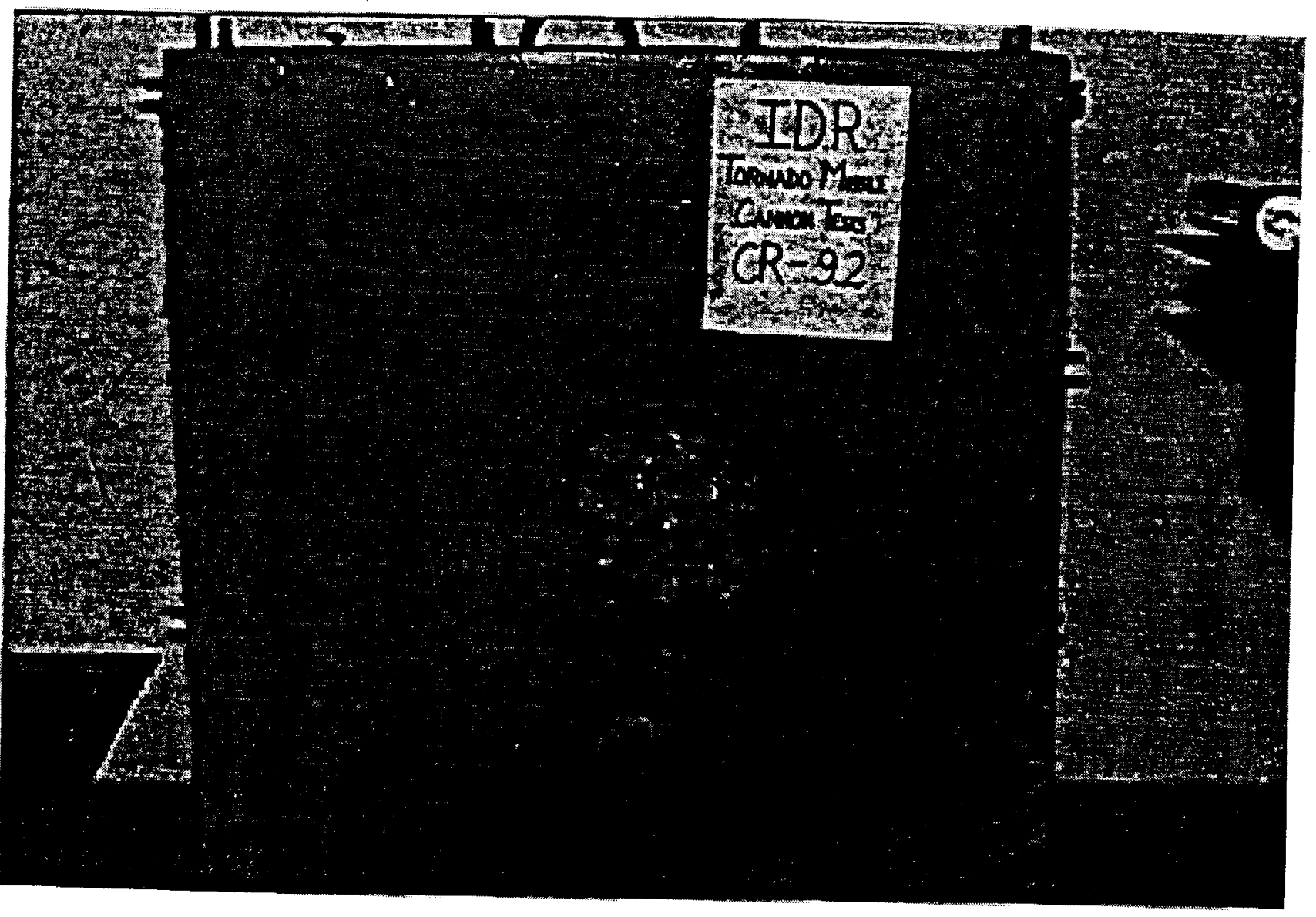

FIGURE 4.26a FRONT FACE OF A CR-9.2 


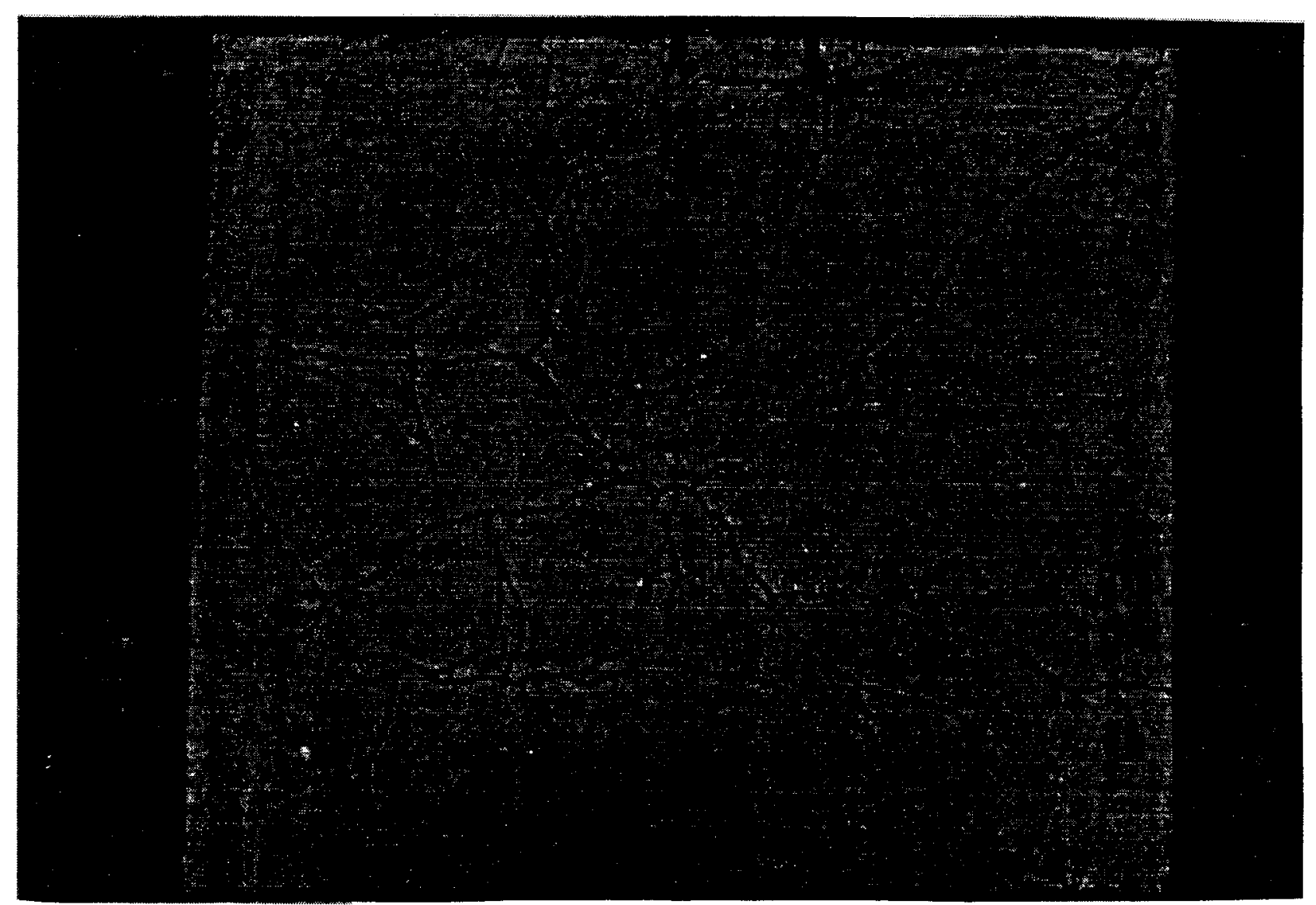

FIGURE 4.26b BACK FACE OF CR-9.2 

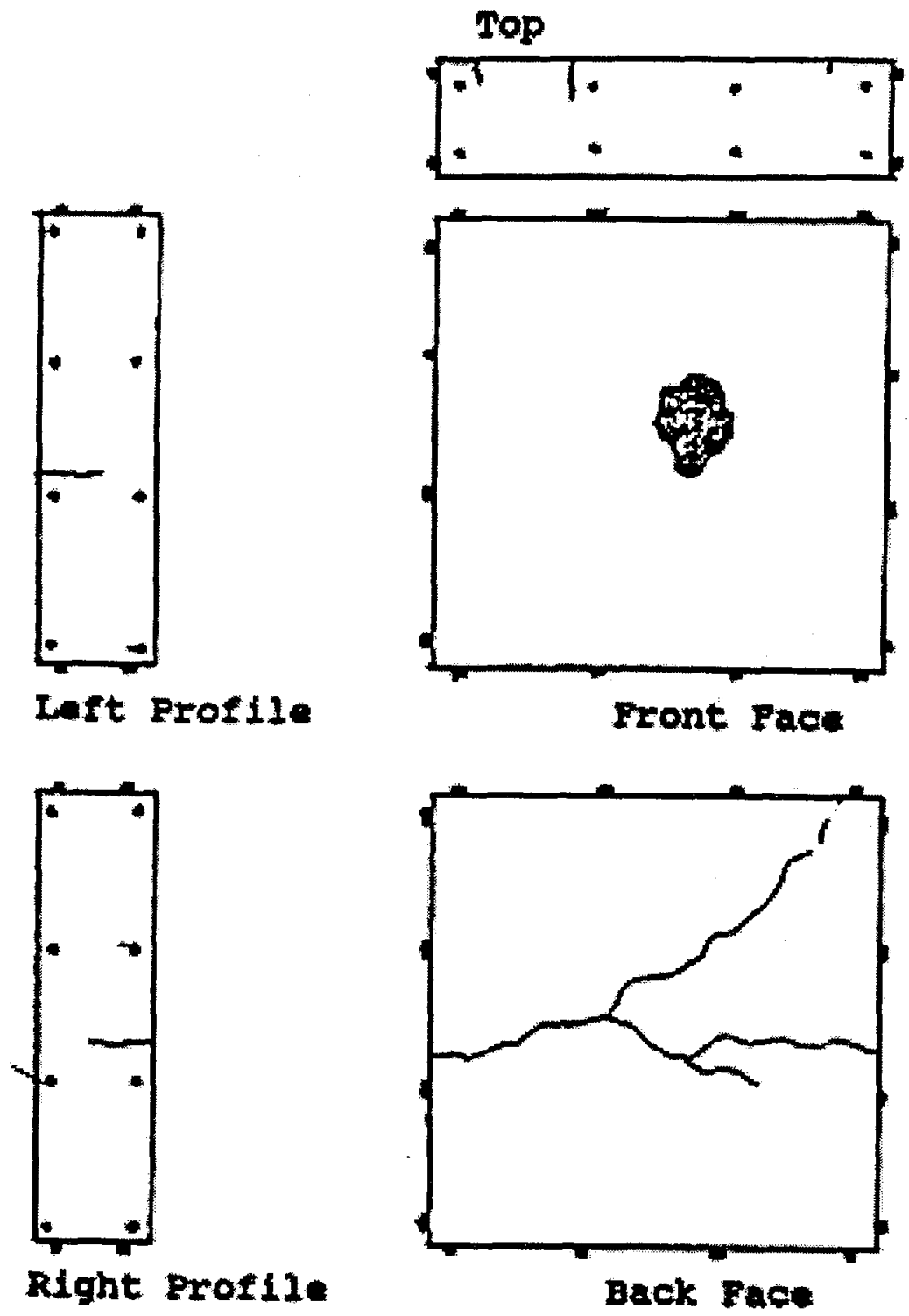

\begin{tabular}{|c|c|c|}
\hline $\begin{array}{c}\text { Barrier } \\
\text { Description }\end{array}$ & $\begin{array}{c}\text { Missile } \\
\text { Speed (mph) }\end{array}$ & Barrier Impact Damage \\
\hline $\begin{array}{l}10 \text {-in. slab with \#4's } \\
12 \text {-in. o.c. each way, placed } \\
1.5 \text {-in. from each face. }\end{array}$ & 74 & $\begin{array}{l}\text { - } 0.81 \text { in. penetration } \\
\text { Radial cracks with } \\
\text { hairline width, cracks } \\
\text { did not propagated } \\
\text { through slab }\end{array}$ \\
\hline
\end{tabular}

FIGURE 4.27 CR-10.1 DATA 


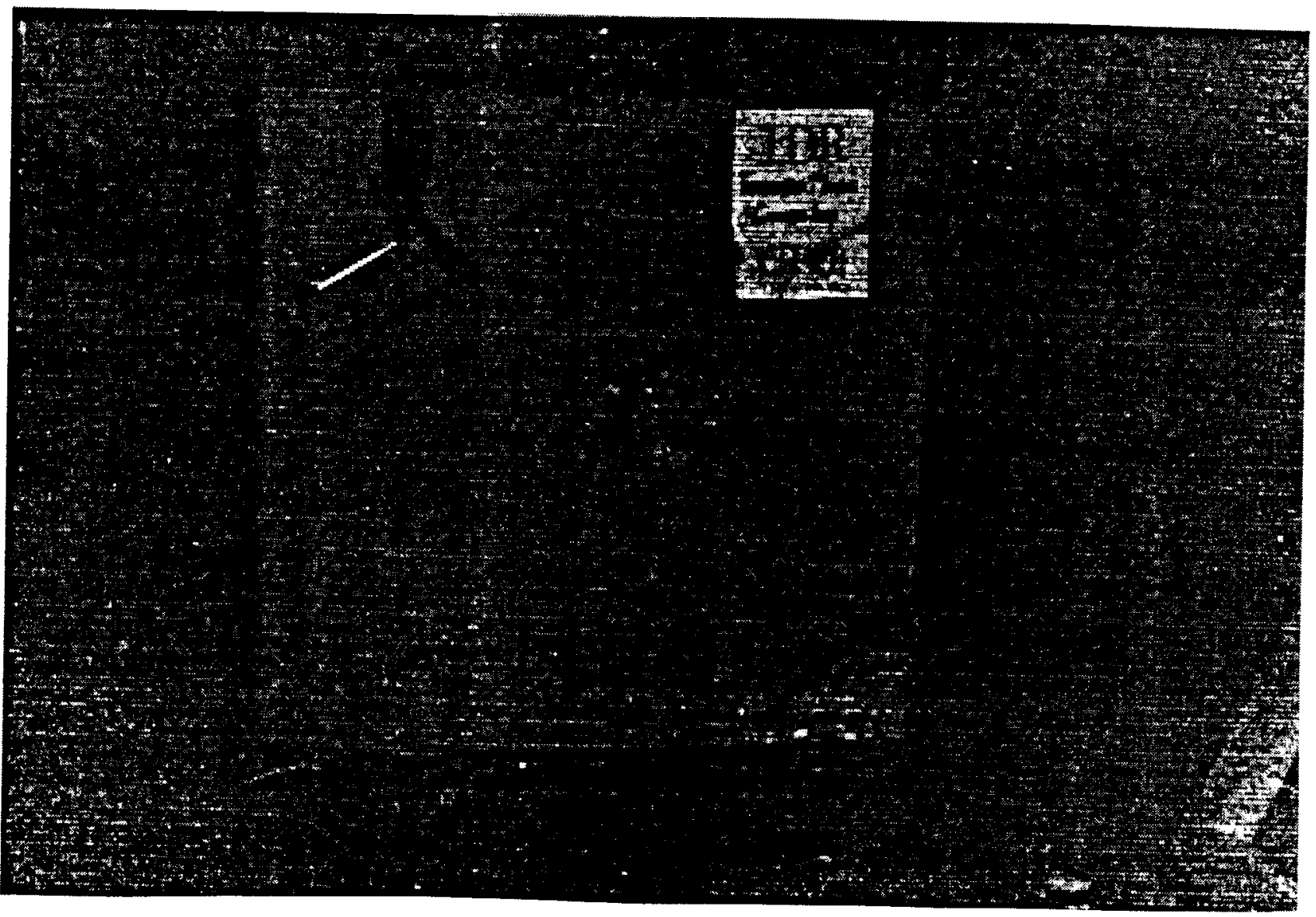

FIGURE 4.28a. FRONT FACE OF CR-10.1 


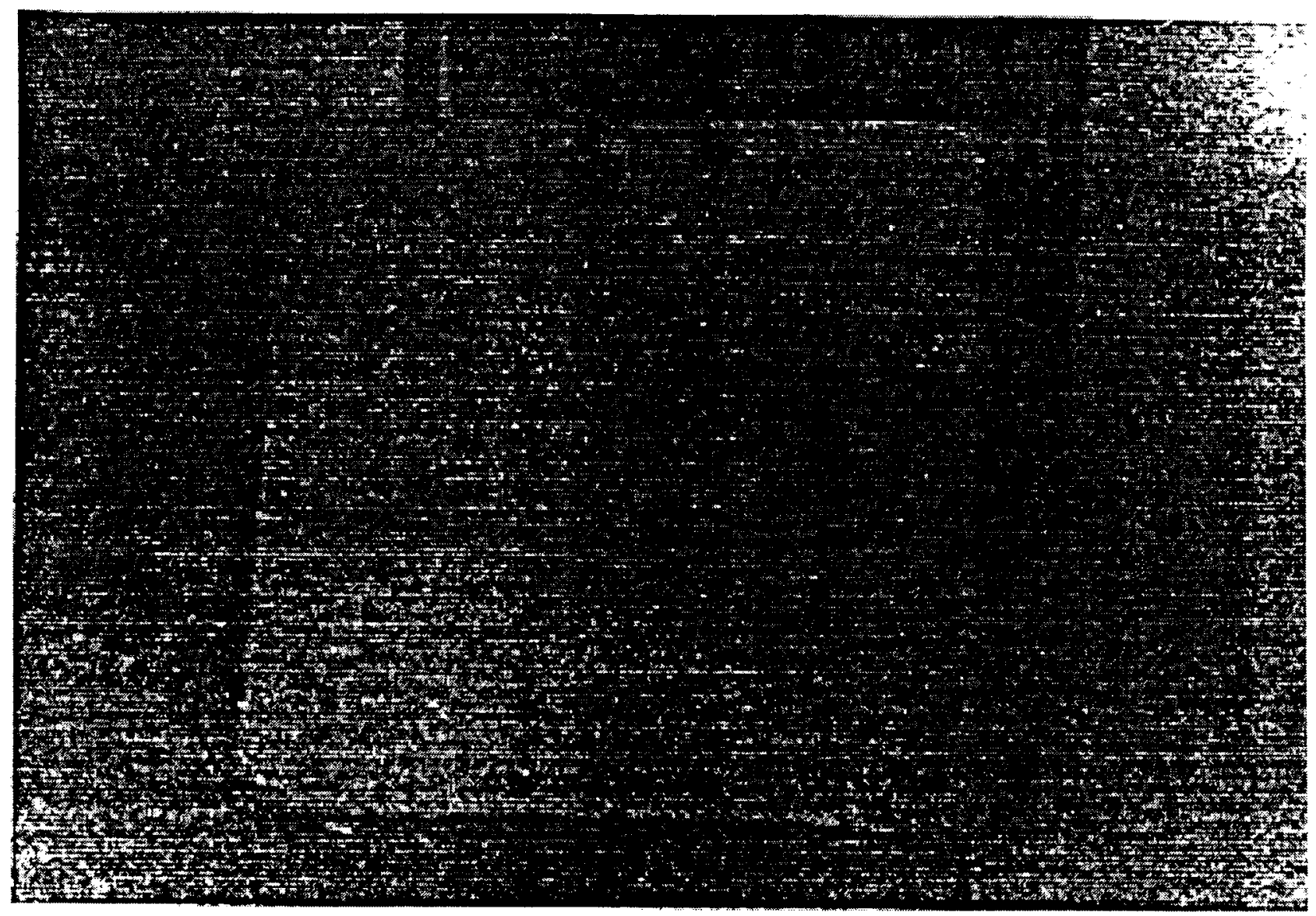

FIGURE 4.28b BACK FACE OF CR-10.1 
Table 4.6 Reinforcing Arrangement Comparison

\begin{tabular}{|c|c|c|c|c|}
\hline $\begin{array}{l}\text { Panel } \\
\text { Thick }\end{array}$ & $\begin{array}{c}\text { Reinforcing } \\
\text { Arrangement }\end{array}$ & $\begin{array}{c}\text { Missile } \\
\text { Impact Speed } \\
\text { (mph) }\end{array}$ & $\begin{array}{l}\text { Panel Damage } \\
\text { Description }\end{array}$ & Comments \\
\hline \multirow{3}{*}{$\frac{\dot{E}}{b}$} & $\begin{array}{l}\text { CR-6.1: \#3 spaced 9-in. } \\
\text { o.c. each way, 1.5-in. from } \\
\text { panel front face }\end{array}$ & 35 & $\begin{array}{l}0.25 \text {-in. penetration; } 0.19 \text {-in. wide } \\
\text { radial cracks on back face, total } \\
\text { propagation }\end{array}$ & $\begin{array}{l}\text { Reinforcement in front face } \\
\text { reduced penetration depth }\end{array}$ \\
\hline & $\begin{array}{l}\text { CR-6.2: \#3 spaced 12-in. } \\
\text { o.c. each way, } 1.50 \text {-in. } \\
\text { from panel back face }\end{array}$ & 36 & $\begin{array}{l}0.38 \text {-in. penetration; } 0.06 \text {-in. wide } \\
\text { radial cracks on back face, total } \\
\text { propagation }\end{array}$ & $\begin{array}{l}\text { Reinforcement in back face } \\
\text { reduced radial crack size }\end{array}$ \\
\hline & $\begin{array}{l}\text { CR-6.3: \#4 spaced 9-in. } \\
\text { o.c. each way, } 1.50 \text {-in. } \\
\text { from panel back face }\end{array}$ & 37 & $\begin{array}{l}0.38 \text {-in. penetration; } 0.06 \text {-in. wide } \\
\text { radial cracks on back face, total } \\
\text { propagation }\end{array}$ & $\begin{array}{l}\text { Reinforcement in back face } \\
\text { reduced radial crack size; } \\
\text { closer rebar spacing did not } \\
\text { influence damage }\end{array}$ \\
\hline \multirow{3}{*}{ 素 } & $\begin{array}{l}\text { CR-8.1: \#4 spaced 9-in. } \\
\text { o.c. each way, in the } \\
\text { middle of panel }\end{array}$ & 44 & $\begin{array}{l}0.38 \text {-in. penetration; } 0.06 \text {-in. wide } \\
\text { radial cracks on back face, total } \\
\text { propagation }\end{array}$ & $\begin{array}{l}\text { Closer rebar spacing } \\
\text { appeared to reduce } \\
\text { penetration depth }\end{array}$ \\
\hline & $\begin{array}{l}\text { CR-8.2: \#4 spaced 12-in. } \\
\text { o.c. each way, in the } \\
\text { middle of panel }\end{array}$ & 44 & $\begin{array}{l}0.63 \text {-in. penetration; } 0.09 \text {-in. wide } \\
\text { radial cracks on back face, total } \\
\text { propagation }\end{array}$ & \\
\hline & $\begin{array}{l}\text { CR-8.3: \#4 spaced 12-in. } \\
\text { o.c. each way, } 1.50 \text {-in. } \\
\text { from each panel face }\end{array}$ & 50 & $\begin{array}{l}0.69 \text {-in. penetration; } 0.09 \text {-in. wide } \\
\text { radial cracks on back facc, } 3 / 4 \\
\text { propagation }\end{array}$ & $\begin{array}{l}\text { Double rebar mats prevented } \\
\text { total propagation of cracks }\end{array}$ \\
\hline \multirow{2}{*}{ 㐫 } & $\begin{array}{l}\text { CR-9.1: \#4 spaced 12-in. } \\
\text { o.c. each way, } 1.50 \text {-in. } \\
\text { from each panel face }\end{array}$ & 50 & $\begin{array}{l}0.44 \text {-in. penetration; hairline radial } \\
\text { cracks on back face, } 1 / 2 \text { propagation }\end{array}$ & $\begin{array}{l}\text { Double rebar mats again } \\
\text { resist crack propagation } \\
\text { through panel }\end{array}$ \\
\hline & $\begin{array}{l}\text { CR-9.2: \#4 spaced 12-in. } \\
\text { o.c. each way, } 1.50 \text {-in. } \\
\text { from each panel face }\end{array}$ & 78 & $\begin{array}{l}1.50 \text {-in. penetration; scabbing, } 1.0 \text {-in. } \\
\text { by } 0.50 \text {-in. fragments. }\end{array}$ & $\begin{array}{l}\text { Double rebar mats again } \\
\text { resist crack propagation } \\
\text { through panel }\end{array}$ \\
\hline 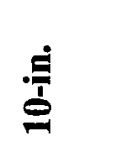 & $\begin{array}{l}\text { CR-10.1: \#4 spaced 12-in. } \\
\text { o.c. each way, } 1.50 \text {-in. } \\
\text { from each panel face }\end{array}$ & 74 & $\begin{array}{l}0.81 \text {-in. penetration; hairline radial } \\
\text { cracks on back face, } 1 / 2 \text { propagation }\end{array}$ & $\begin{array}{l}\text { Double rebar mats again } \\
\text { resist crack propagation } \\
\text { through panel }\end{array}$ \\
\hline
\end{tabular}




\subsubsection{Reinforced Masonry Panels}

Four reinforced masonry wall panels were designed and constructed to resist the $50 \mathrm{mph}$ and $75 \mathrm{mph}$ impacts of the pipe missile as required by DOE STD 1020-94 for PC3 and PC4 SSCs. Two panels were constructed of reinforced and grouted CMUs. The other two consisted of a clay brick cavity wall and a clay brick veener/CMU combination wall.

The 8-in. CMU wall (CMU-8.1)was perforated by the steel pipe at an impact speed of $51 \mathrm{mph}$ (see Figures 4.29, 4.30a, and 4.30b). This was the only wall in the test series that was perforated. Large pieces of block and grout weighing between 7 and $14 \mathrm{lb}$ were found 8 to $10 \mathrm{ft}$ behind the panel. A vertical crack passed through the impact point and propagated through the wall thickness. The missile perforation produced a 4-in. diameter entrance hole on the front face. A volume of material 25.2 in. by 14.5-in. in a conical, oval shape was ejected from the back face. The impact point was between the vertical rcinforcing bars, which represents a worst case location.

Two impact tests were performed on the 12-in. CMU wall. In the test, the pipe missile accidentally struck the metal rebound guard that protects the timing gate. The missile was due to missile launcher recoil. After striking the rebound guard, the missile hit the test panel at an unknown velocity that was estimated at less than $20 \mathrm{mph}$. The missile penetrated 0.50 . Into the panel at a point 3.50 in.to the right of center and one-half inch from where a vertical rebar was located. The impact caused a 0.13 in. wide vertical crack on the back face.

Before the second test, the slab was moved about 4-in. to the left to avoid the previous impact point. Since CMU -8.1 was perforated at $50 \mathrm{mph}$, it was assumed that 
CMU-12.2 would not withstand a $75 \mathrm{mph}$ impact without scabbing. Therefore, a CMU12.2 was struck at an impact speed of $59 \mathrm{mph}, 6$-in. to the left of center and 2 -in. from a vertical rebar. This impact caused a 1.38 penetration and a large vertical crack on the back face. Small block and grout fragments weighing less than $0.6 \mathrm{lb}$ ejected from the back face, indicating that the scabbing threshold was near $60 \mathrm{mph}$. The crack and scabbing pattern, as illustrated in Figures 4.31, 4.32a and 4.32b, appeared to independent of damage created by the first impact. The vertical cracking on this panel and on the 8in. CMU panel suggest that both panels need additional horizontal joint reinforcement to mitigate cracks.

Neither of the CMU barriers performed as expected. CMU-8. 1 could not resist the $50 \mathrm{mph}$ pipe missile. CMU-12.2 could not resist the $75 \mathrm{mph}$ impact without significant scabbing. However, since the scabbing threshold velocity for the 12 -in. CMU was approximately $60 \mathrm{mph}$, this panel satisfies the $50 \mathrm{mph}$ impact criteria of the steel pipe missile.

\subsection{Recommended Missile barriers}

Based on data from literature and results of impact tests at Texas Tech University, the following guidelines are recommended for missile barriers to resist missiles specified in DOE STD 1020-94 

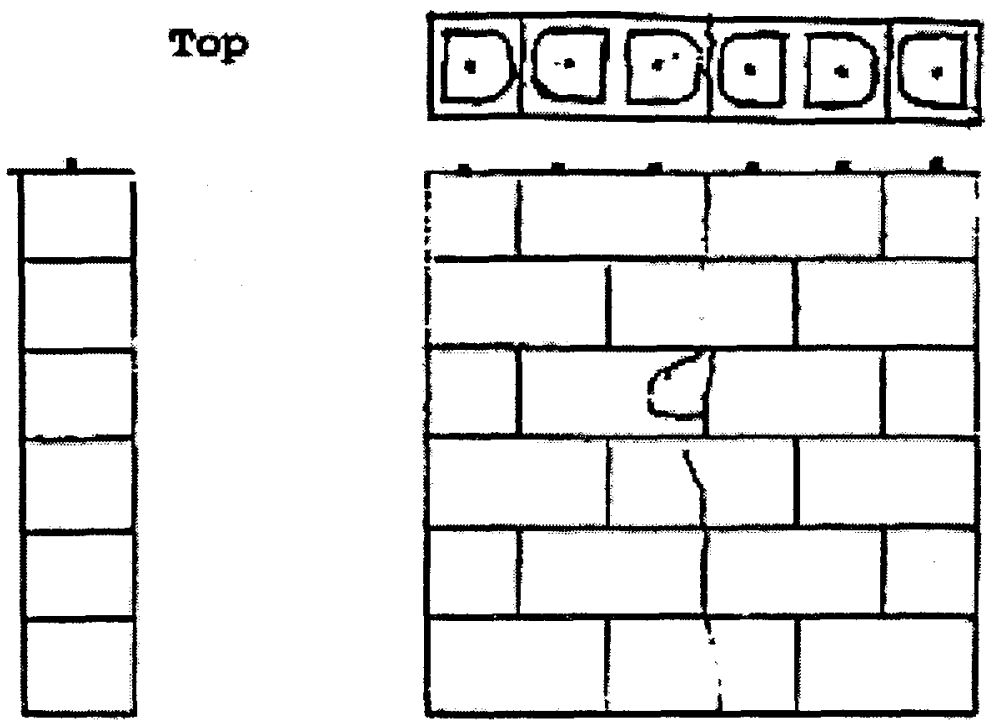

Left Profile

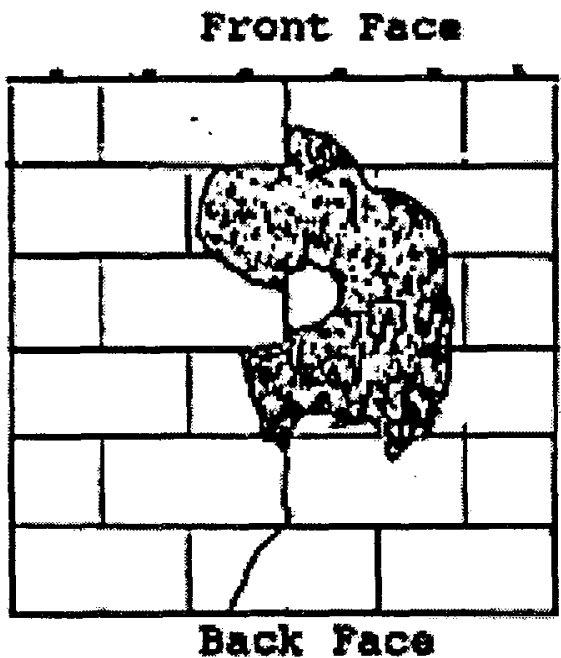

Right Profile

$$
\text { Back Pace }
$$

\begin{tabular}{|c|c|c|}
\hline $\begin{array}{l}\text { Barrier } \\
\text { Description }\end{array}$ & $\begin{array}{l}\text { Misila } \\
\text { Speed }\end{array}$ & Barrier Impact Damage \\
\hline $\begin{array}{l}\text { in. groutad cut } \\
\text { wal with } 4 \text { 'b } \\
\text { in. o.c. } \\
\text { horizontal ties } 16 \\
\text { in. o.c. }\end{array}$ & $51 \mathrm{mph}$ & $\begin{array}{l}\text {-Total perforation } \\
\text {-Pieces of scabbing teighing } \\
\text { betueen } 7 \text { and } 14 \text { lbs. } \\
\text { - Entrance hola: } 4 \text { in. ala.. } \\
\text { exit hole: } 25.5 \text { in. } \% 14.5 \\
\text { in. oval }\end{array}$ \\
\hline
\end{tabular}

FIGURE 4.29 CMU-8.1 DATA 


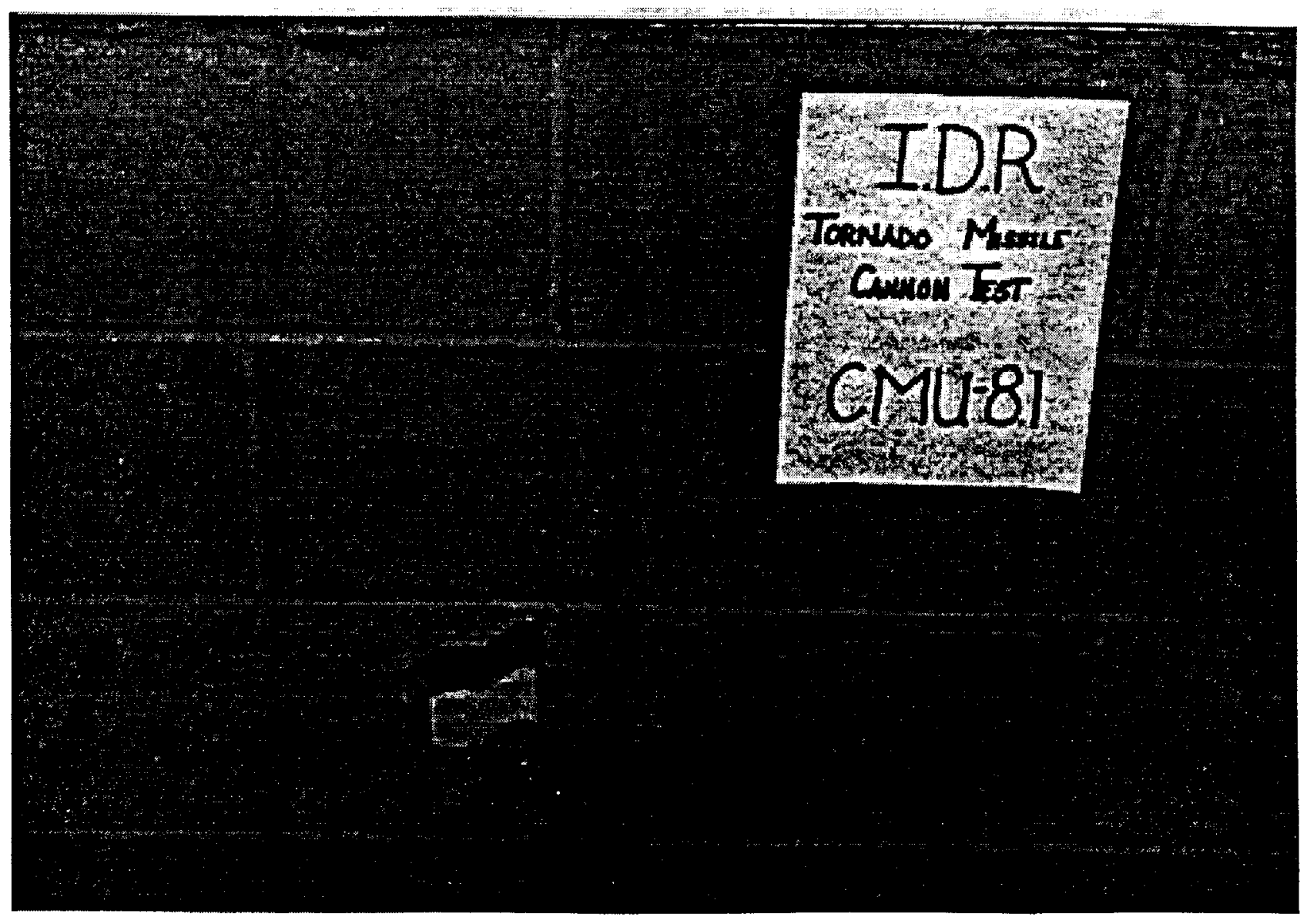

FIGURE 4.30a. FRONT FACE OF CMU- 8.1 


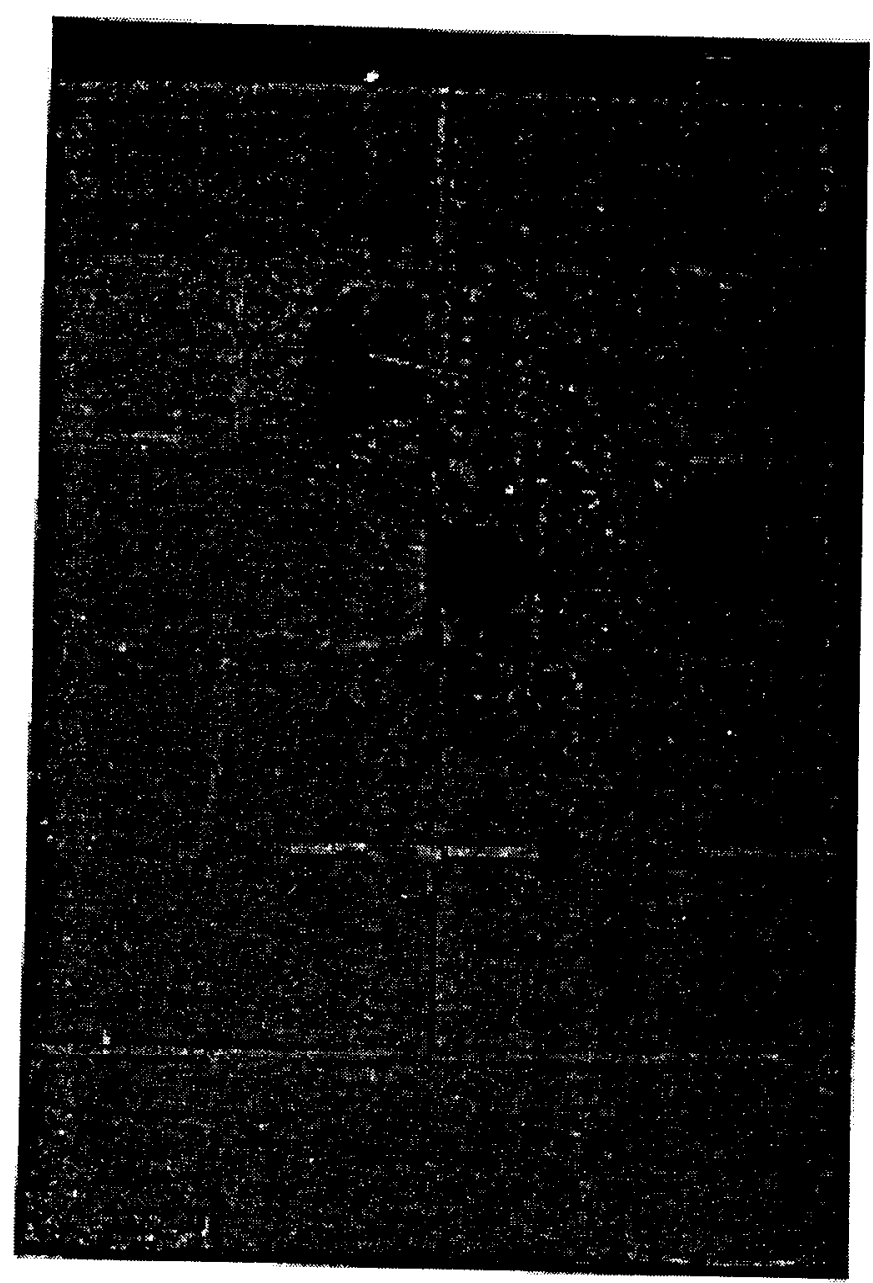

FIGURE 4.30b. BACK FACE OF CMU-8.1 


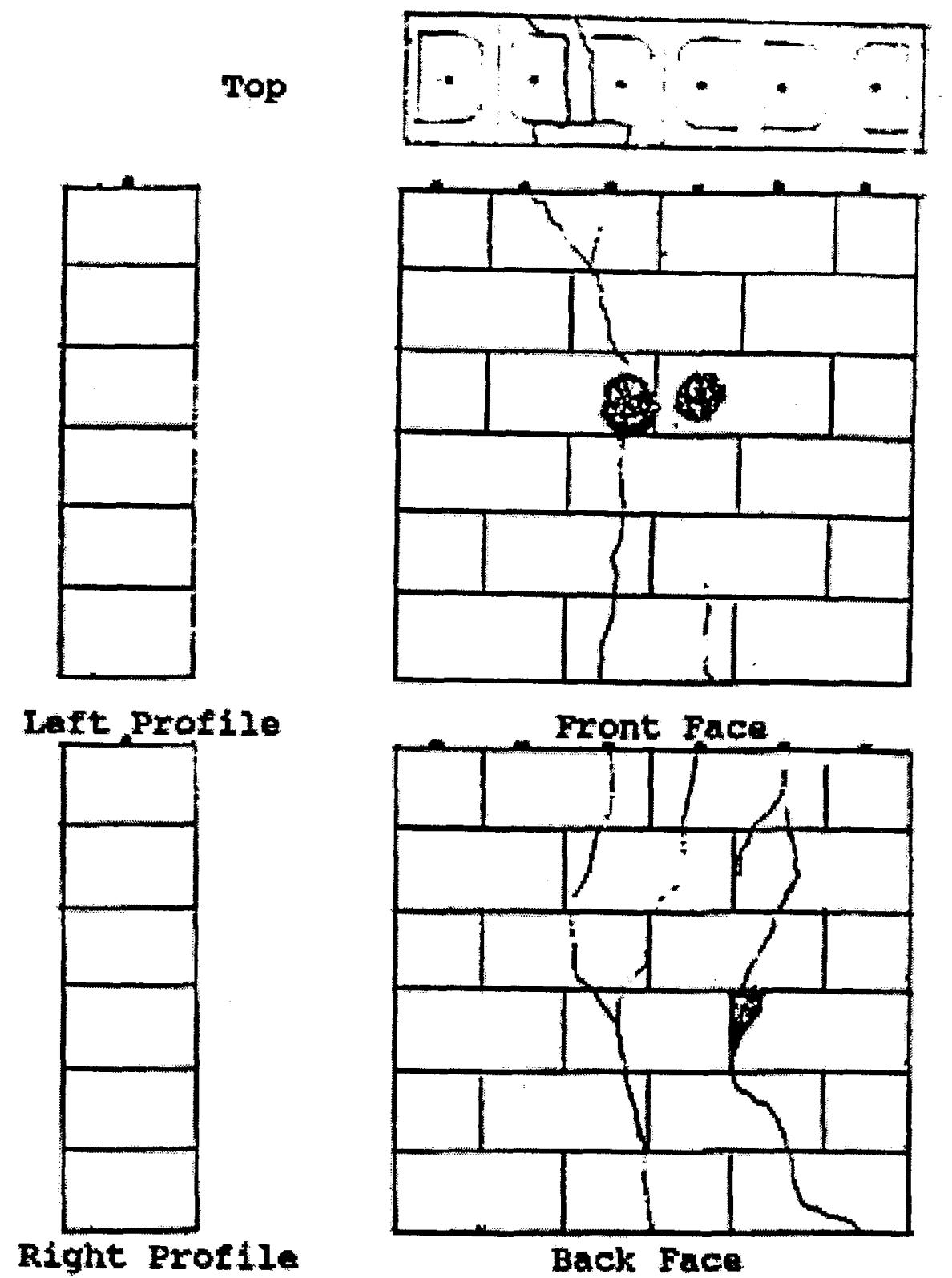

\begin{tabular}{|l|c|c|}
\hline \multicolumn{1}{|c|}{\begin{tabular}{c}
\multicolumn{1}{|c|}{ Barricr } \\
Description
\end{tabular}} & \multicolumn{1}{|c|}{$\begin{array}{c}\text { Missile } \\
\text { Speed (mph) }\end{array}$} & Barrier Impact Damage \\
\hline $\begin{array}{l}\text { 12 -in. grouted CMU wall } \\
\text { with \#4's, 8in.o.c. } \\
\text { horizontal } \\
\text { ties 16-in. o.c.. }\end{array}$ & 59 & $\bullet 1.38$ in. penetration \\
& & $\begin{array}{l}\text { Threshold of scabbing } \\
\text { reached, scabbing pieces } \\
\text { weighed up to 0.6 lbs. }\end{array}$ \\
\hline
\end{tabular}

FIGURE 4.31 CMU-12.2 DATA 


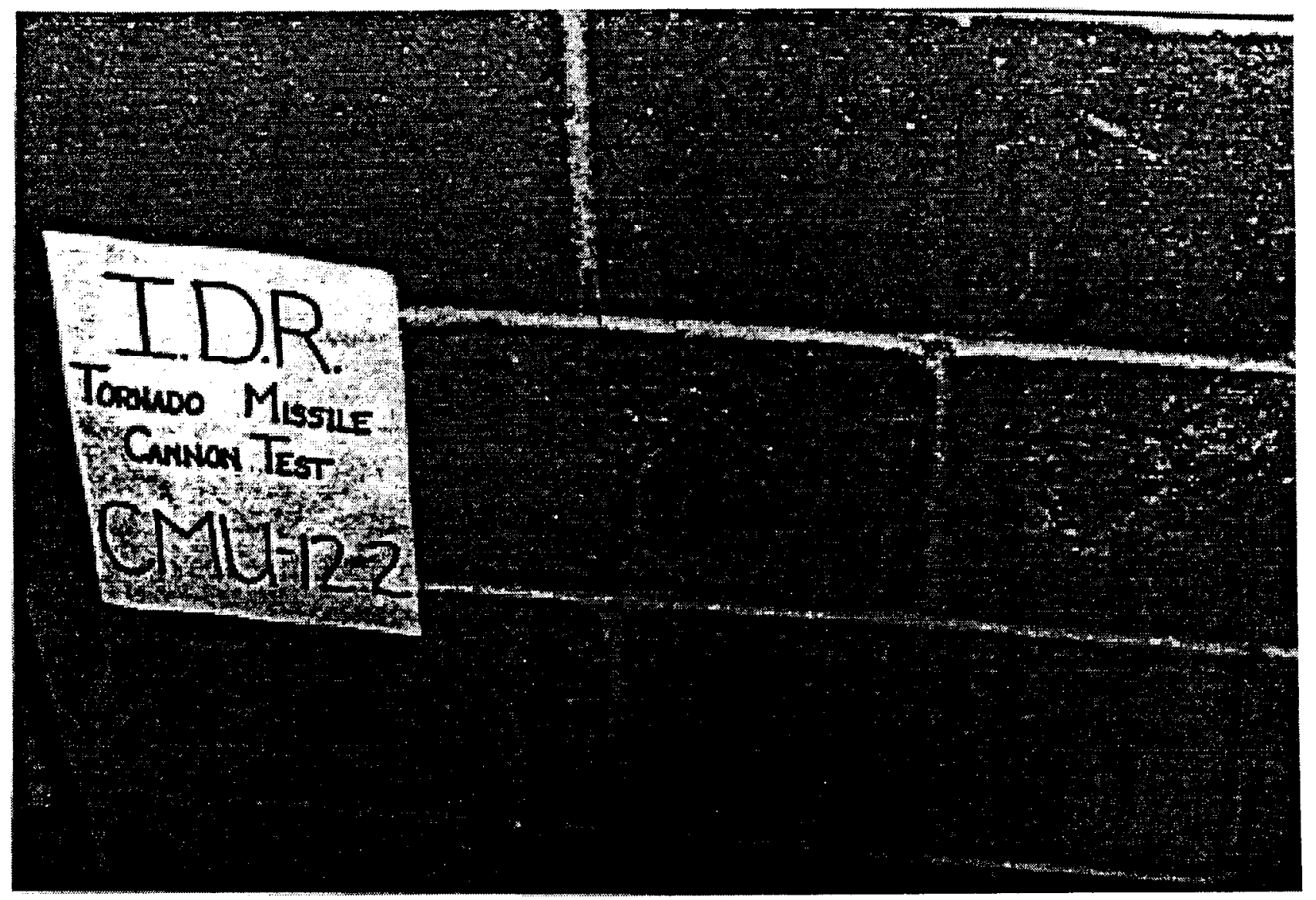

FIGURE 4.32a FRONT FACE OF CMU-12.2 

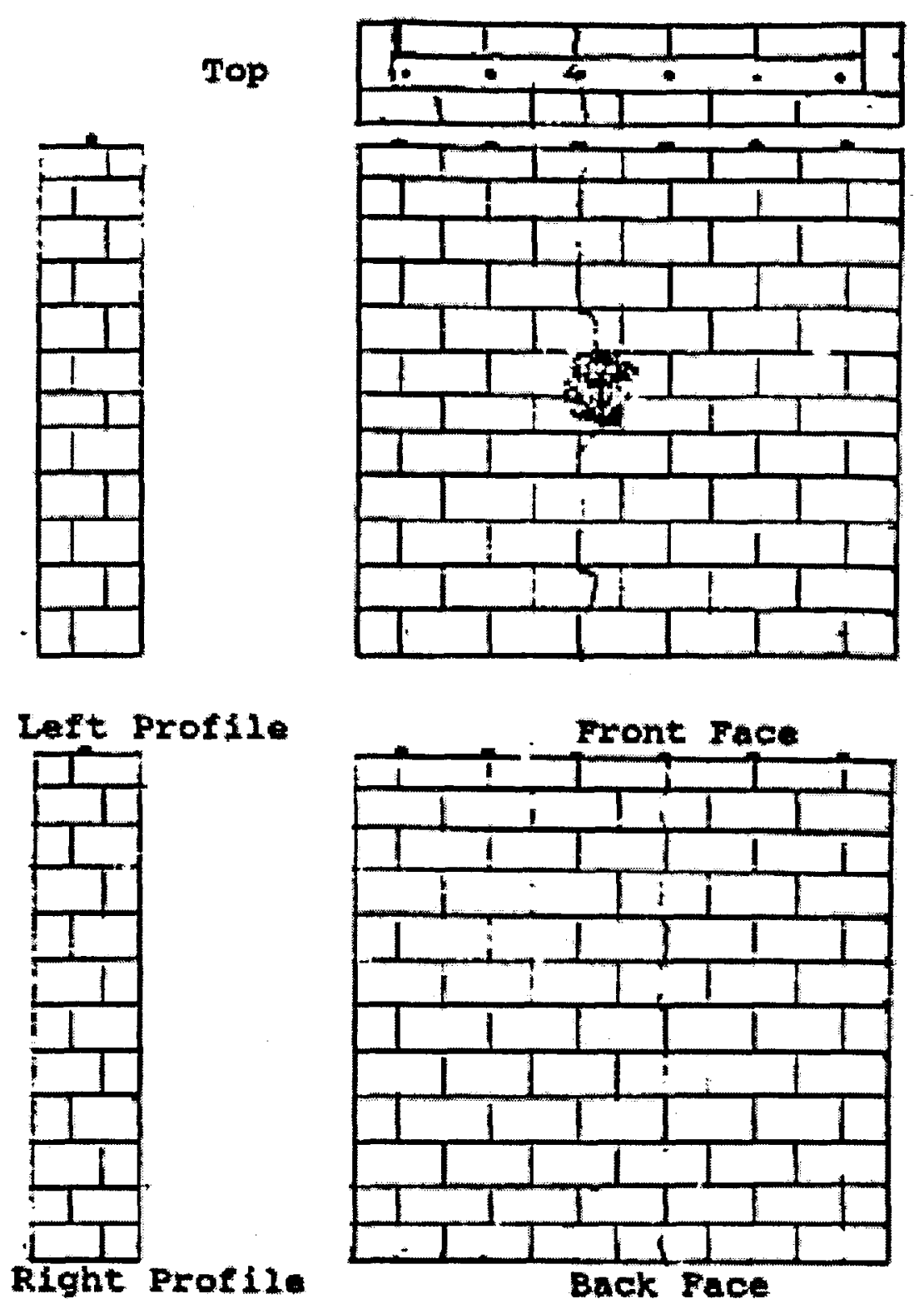

\begin{tabular}{|l|c|c|}
\hline \multicolumn{1}{|c|}{\begin{tabular}{c}
\multicolumn{1}{|c|}{ Barrier } \\
Description
\end{tabular}} & \multicolumn{1}{c|}{$\begin{array}{c}\text { Missile } \\
\text { Speed (mph) }\end{array}$} & Barrier Impact Damage \\
\hline $\begin{array}{l}\text { 9.5-in. brick cavity wall } \\
\text { (grouted ) with \#4's, }\end{array}$ & 50 & $\bullet$ 1.13-in. penetration \\
$\begin{array}{l}\text { 8in.o.c. and } \\
\text { horizontal ties 16-in. o.c. }\end{array}$ & $\begin{array}{l}\text { Vertical crack with 0.25- } \\
\text { in. width, crack propagated } \\
\text { through wall }\end{array}$ \\
\hline
\end{tabular}

FIGURE 4.33 CBM-(9.5).1 DATA 


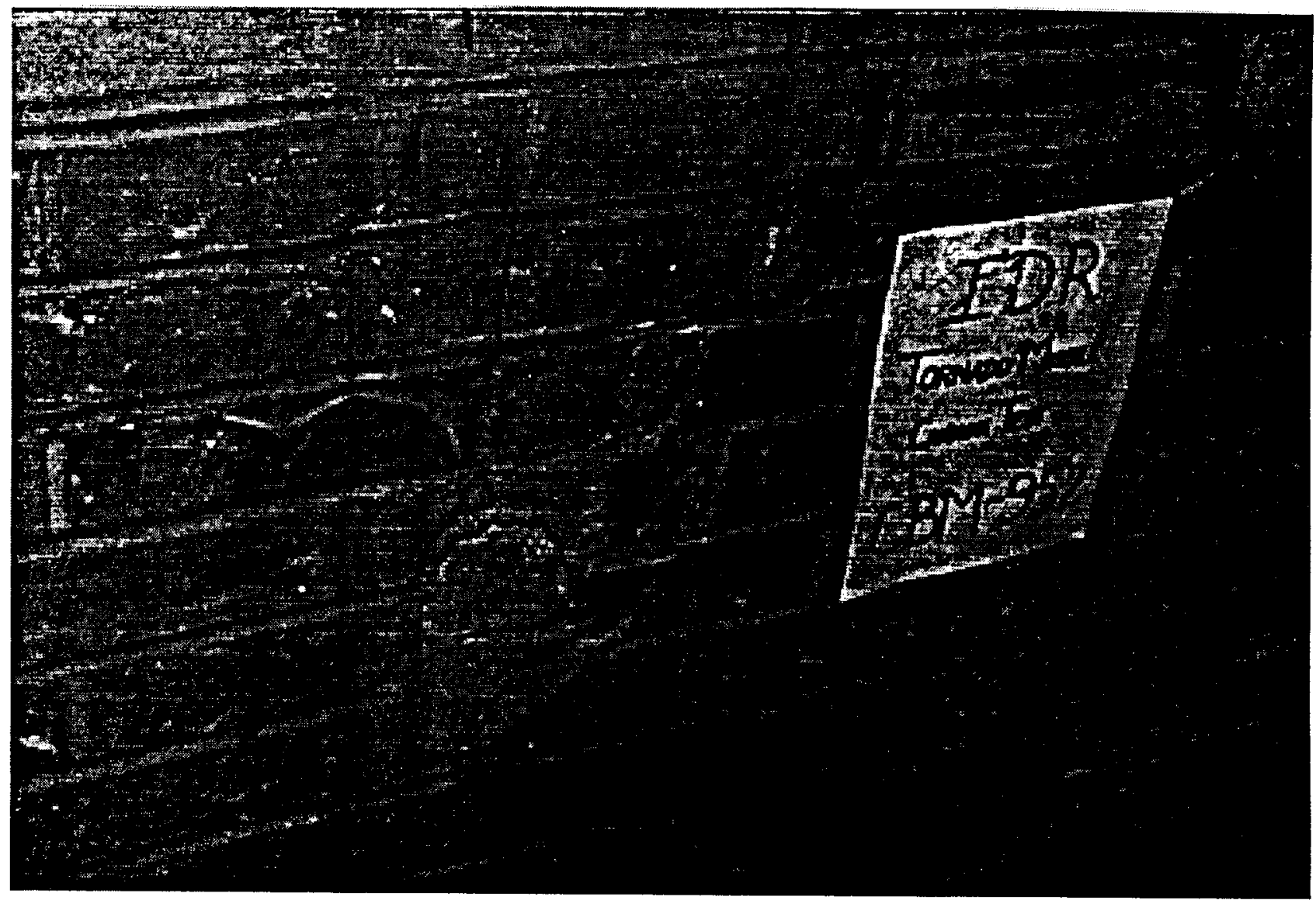

FIGURE 4.34a. FRONT FACE OF CBM-(9.5).1 


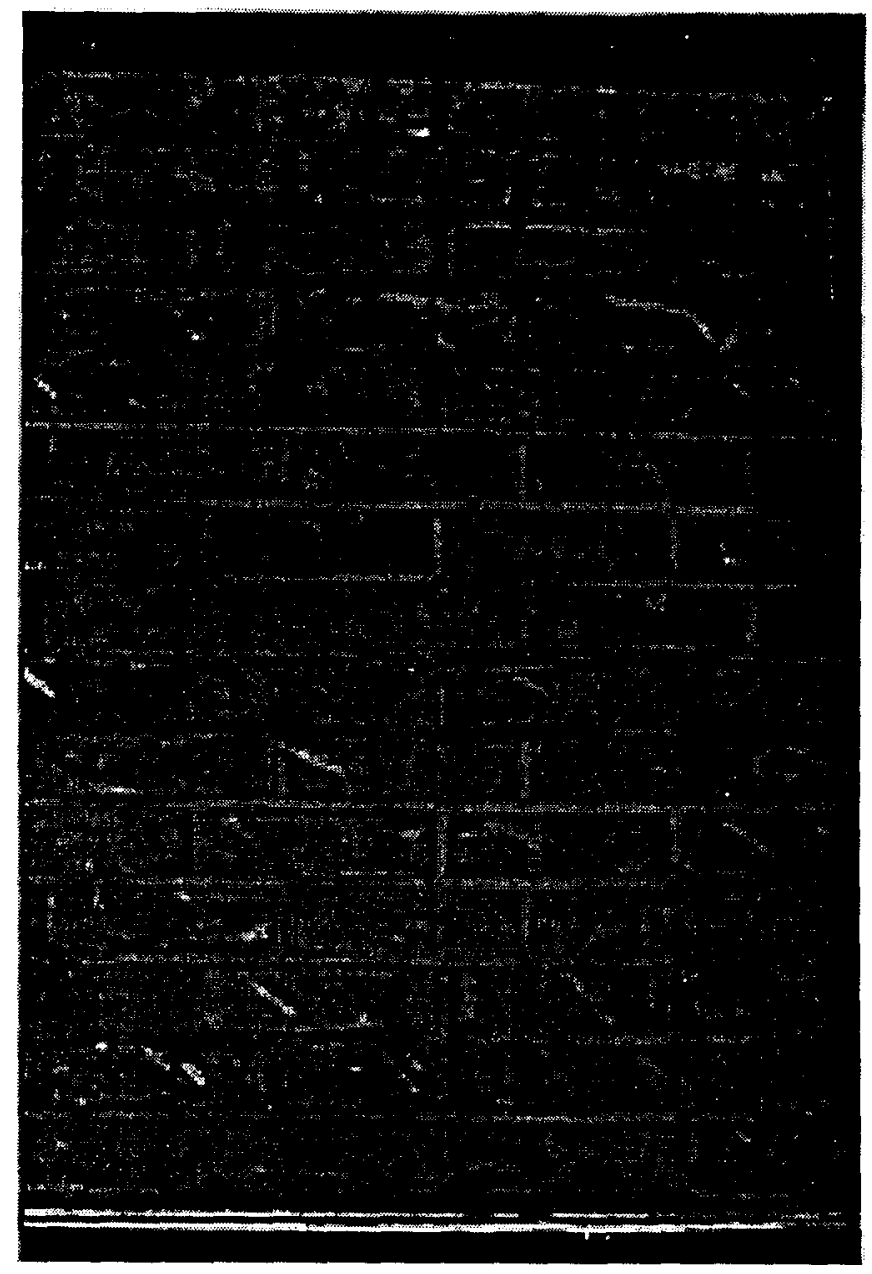

FIGURE 4.34b. BACK FACE OF CBM-(9.5).1 

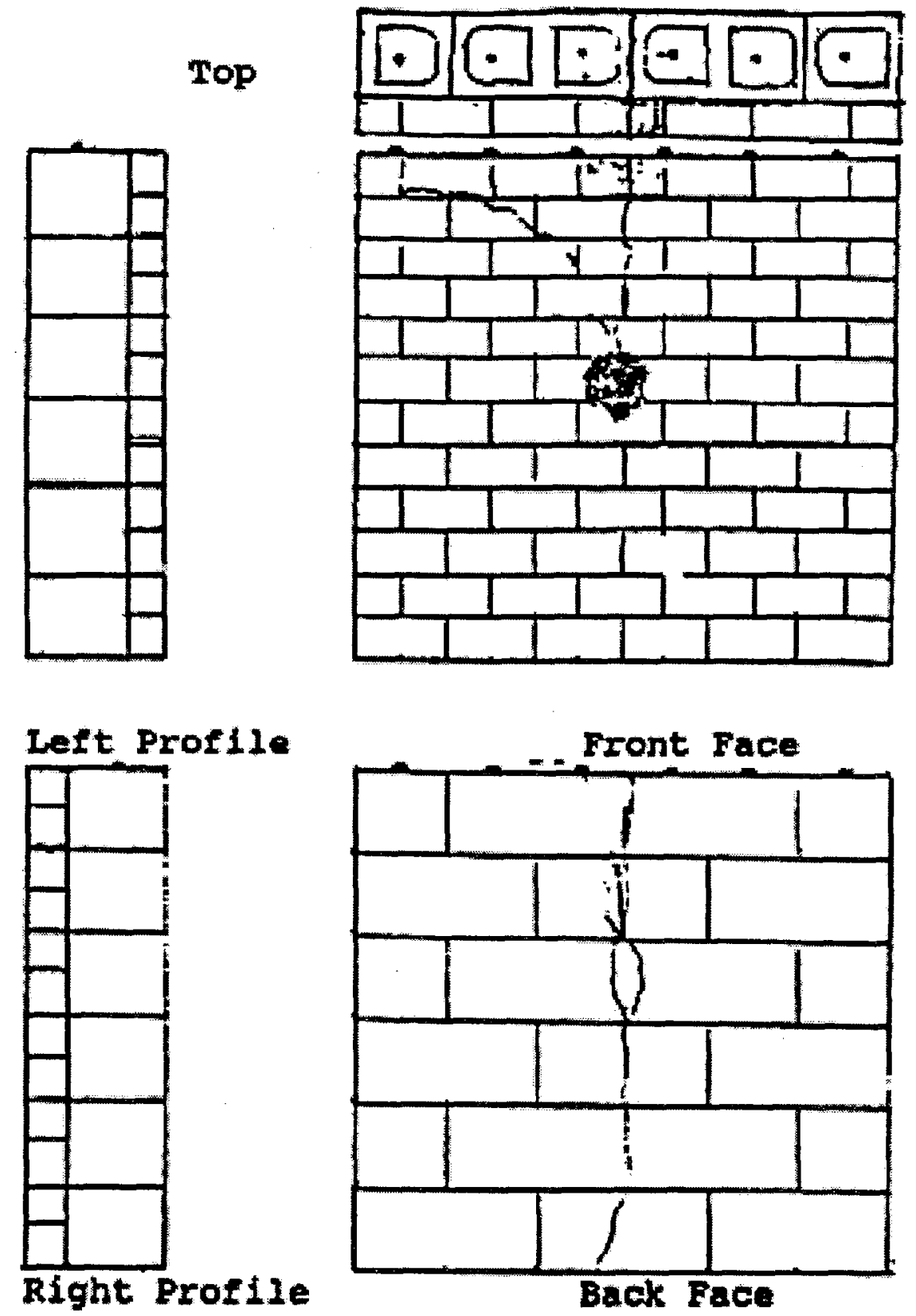

\begin{tabular}{|l|c|l|}
\hline \multicolumn{1}{|c|}{\begin{tabular}{c}
\multicolumn{1}{|c|}{ Barrier } \\
Description
\end{tabular}} & \multicolumn{1}{c|}{$\begin{array}{c}\text { Missile } \\
\text { Speed (mph) }\end{array}$} & Barrier Impact Damage \\
\hline $\begin{array}{l}\text { 8-in. grouted CMU wall } \\
\text { with \#4's, 8in.o.c. } \\
\text { horizontal } \\
\text { ties 16-in. o.c. single brick } \\
\text { wythe } \\
\text { on the front face }\end{array}$ & 50 & $\bullet 1.13$-in. penetration \\
& & $\begin{array}{l}\text { Vertical crack with max. } \\
\text { width of 0.38-in.crack } \\
\text { propagatcd through wall }\end{array}$ \\
\hline
\end{tabular}

FIGURE 4.35 CBCMU-12.1 DATA 


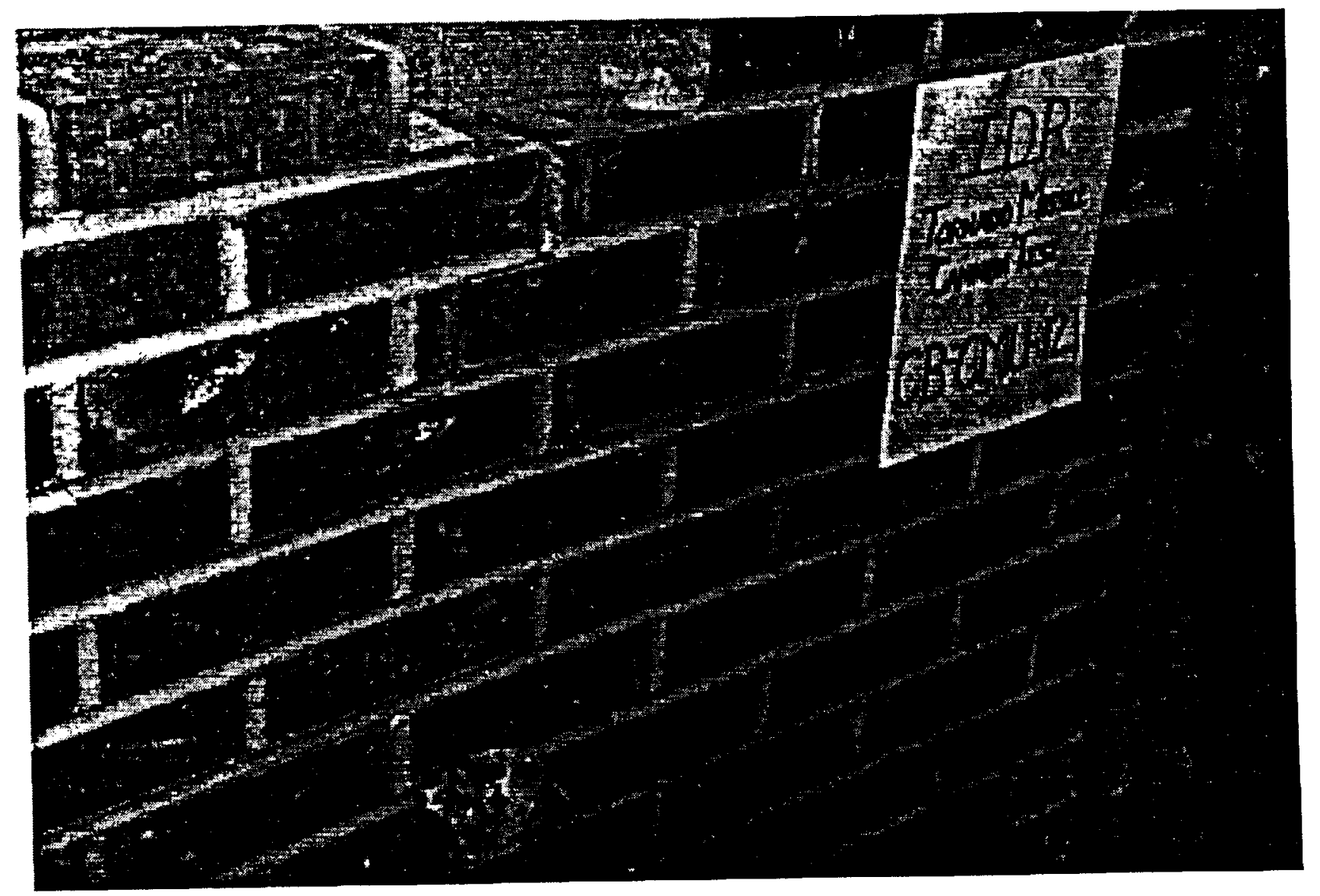

FIGURE 4.36a. FRONT FACE OF CBCMU-12.1 


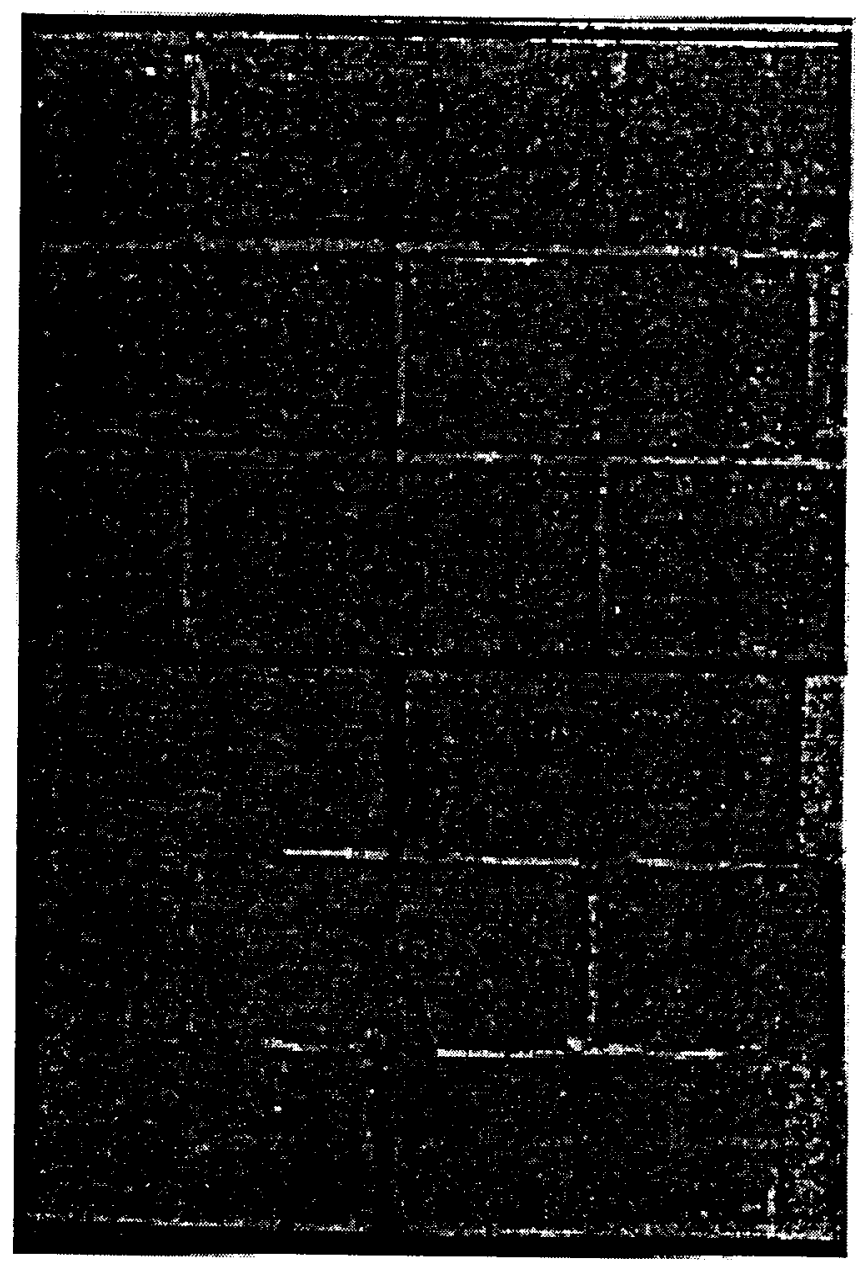

FIGURE 4.36b. BACK FACE OF CBCMU-12.1 


\subsubsection{Barriers for Performance Category 3}

The missile criteria is

Horizontal Missile Component:

$2 \times 4$ timber (15 lb.) at $100 \mathrm{mph}$, maximum height above ground $150 \mathrm{ft}$.

Recommended Barrier:

1. 8-in. CMU wall with one \#4 rebar grouted in each vertical call and trussed horizontal joint reinforcement at 16 in. on center,

2. Single wythe brick veneer attached to stud wall with metal ties,

3. 4-in. concrete slab with \# 3rebar at 6 in. on center each in the middle of slab.

\section{Vertical Missile Component}

$2 \times 4$ timber $(15 \mathrm{lb})$ at $100 \mathrm{mph}$

Recommended Barrier:

1. 4-in. concrete slab with \# 3 rebar at 6 in.on center each in the middle of slab.

Horizontal Missile Component:

3-in. diameter steel pipe $\mathrm{lb}$ at $50 \mathrm{mph}$; maximum height above ground $75 \mathrm{ft}$.

Recommended Barrier:

1. 12-in. CMU wall with \#4 rebar in each vertical cell and grouted; \#4 rebar horizontal at 8 in. on center.

2. Nominal 12-in. wall consisting of 8 -in. CMU with \#4 rebar in each vertical cell and grouted; \#4 rebar horizontal at 8 in. on center; single wythe clay brick masonry on outside face of wall; horizontal ties at 16 in. on center

3. 9.5-in. reinforced brick cavity wall with \#4 rebar at 8-in. center each way in the cavity; cavity filled with 2500 psi concrete; horizontal ties at 16 in. on center, 
4. 8-in. concrete slab with \# 4 rebar in on center each way 1.5 in. from inside.

Vertical Component:

3-in. diameter steel pipe $75 \mathrm{lb}$. At $35 \mathrm{mph}$

Recommended Barrier:

1. 6-in. concrete slab with \#4 rebar at 12 in. on center each way $1.5 \mathrm{in}$. from inside face.

\section{Wind-borne Missile}

$2 \times 4$ timber (15) at $50 \mathrm{mph}$; maximum height above ground $30 \mathrm{ft}$.

Recommended Barriers:

1. 8-in. CMU wall with one \#4 rebar grouted in each vertical cell

2. Single wythe brick veneer attached to stud wall with metal ties

3. 4-in. concrete slab with \# 3 rebar at 6 in.on center each in the middle of slab

\subsubsection{Barriers for Performance Category 4}

The Missile Criteria is

Horizontal Missile Component:

$2 \times 4$ timber (15 lb.) at $150 \mathrm{mph}$, maximum height above ground $200 \mathrm{ft}$.

Recommended Barrier:

1. 6-in. concrete slab with \# 4 rebar in on center each way 1.5 in. in the middle of the slab.

2. 8-in. CMU wall with one \#4 rebar grouted in each vertical cell and horizontal trussed joint reinforcement at 16 in. on center.

Vertical Component:

$2 \times 4$ timber (15 lb.) at $100 \mathrm{mph}$ 
Recommended Barrier:

1. 4-in. concrete slab with \#3 rebar at 6 in. on center each in the middle of the slab

Horizontal Missile Component:

3-in. diameter steel pipe $75 \mathrm{lb}$. At $75 \mathrm{mph}$; maximum height above ground $100 \mathrm{ft}$.

Recommended Barrier:

1. 10-in. concrete slab with \#4 rebar at 12 in. on center each way 1.5 in. from inside face.

\section{Vertical Component:}

3-in. diameter steel pipe $75 \mathrm{lb}$. At $50 \mathrm{mph}$

1. 8 -in. concrete slab with \#4 rebar at 8 in. on center each way 1.5 in. from inside face.

\section{Windborne Missile}

$2 \times 4$ timber (15 lb.) at $50 \mathrm{mph}$ maximum height above ground $30 \mathrm{ft}$.

1. 8-in. CMU wall with \#4 rebar grouted in each vertical cell,

2. Single wythe brick veneer attached to stud wall with metal ties

3. 4-in. concrete slab with \# 3 rebar at 6 in.on center each in the middle of slab. 


\section{REFERENCES}

ASCE, 1990: Minimum Design Loads for Buildings and Other Structures, ASCE 7-88, American Society of Civil Engineers, Denton, VA.

Bates, F.C. and Swanson, A.E. 1967: Tornado Design Consideration for Nuclear Power Plants, The American Nuclear Society's Annual Meeting, Chicago, IL.

Bailey, James R., 1984. 'Wall Barrier Resistance to the Impact of Tornado Missiles," Master's Thesis, Department of Civil Engineering, Texas Tech University, Lubbock, Texas

Beason, W. Lynn, and Minor, Joseph E., 1976. "Window Glass Failures in Windstorms," Journal of the Structural Division, American Society of Civil Engineers, New York.

Beeth, D.R. and Hobbs, S.H., 1975: Analysis of Tornado Generated Missiles, Tropical Report B \& R-001, Brown and Root, Inc., Houston, TX.

Breen, John E., Chairman, 1989. "Building Code Requirements for Reinforced Concrete (ACI 318-89) and Commentary (ACI 318R-89), American Concrete Institute, Detroit, Michigan.

Burdette, E.G., James, R.A., and Sun, C.N., 1974: The Generation of Missiles, Division of Engineering Design Report TVA-TR-74-1, Tennessee Valley Authority, Oak Ridge, TN.

Coats, D.W., and Munag, R.C., 1985: Natural Phenomena Hazards Modeling Project:

Extreme Wind / Tornado Hazard Models for Department of Energy Situ, UCRL-53526, Rev1., Lawrence Livermore National Laboratory, Livermore, CA.

Costello, J.F., 1976: "Trajectories of Tornado-Borne Missiles," Proceedings of the Symposium on Tornadoes: Assessment of Knowledge and Implications for Man, Texas Tech University, Lubbock, TX.

DOE, 1993: Natural Phenomena Hazard Performance Categorization Guidelines for structure, Systems and Components DOE-STD-1021-93, U.S. Department of Energy, Washington, DC 20585

DOE, 1994: Natural Phenomena Hazard Design and Evaluation Criteria for Department of Energy Facilities, DOE-STD-1020-94, U.S. Department of Energy, Washington, DC 20585.

Fujita, T.T., 1970: "The Iubbock Tornadoes: A Study of Suction Spots," Weatherwise, Vol. 23, No. 4. 
Fujita, T.T., 1971: Proposed Characterization of Tornadoes and Hurricanes by Area and Intensity, SMRP Research Paper No. 90, University of Chicago, Chicago, IL.

Fujita, T.T., 1971: Proposed Characterization of Tornadoes and Hurricanes by Area and Intensity, SMRP Research Paper No. 91, University of Chicago, Chicago, IL.

Fujita, T.T., 1978: Workbook of Tornado and High Winds for Engineering Applications, University of Chicago, SMRP Research Paper 165, Chicago, IL.

Fujita, T.T., 1979: Preliminary Report of the Bossier City Tornado of December 3, 1978, SMRP Research Paper 169, The University of Chicago, Chicago, IL.

Harris, Philip Lloyd, 1978. "The Effects of Thickness and Temper on the Resistance of Glass to Small Missile Impact," Master's Thesis, Department of Civil Engineering, Texas Tech University, Lubbock, Texas.

Hoecker, W.H., Jr., 1960: "Wind Speed and Air Flow Patterns in the Dallas Tornado of April 2, 1957," Monthly Weather Review, Vol. 88, No. 5, pp. 167-180.

Iotti, R.C., 1975: Design Basis Velocities of Tornado Generated Missiles, paper presented at Annual Conference of American Nuclear Society, New Orleans, LA.

Johnson, B. and Abbot, 1977: Monte Carlo Simulation of Tornado Missiles, Pilgrim Nuclear Power Plant, SAI, San Francisco, CA.

Kapur, K.C. and Lamberson, L.R., 1978: Reliability in Engineering Design, Department of Industrial Engineering and Operations Research, Wayne State University, MI.

Kennedy, R.P., 1975. "A Review of Procedures for the Analysis and Design of Concrete Structures to Resist Missile Impact Effects," Holmes and Narver, Inc., Anaheim, California.

Kennedy, R.P., McCann, M.W., McDonald, J.R., Murray, R.C., Short, S.A., 1989. "Design and Evaluation Guidelines for Department of Energy Facilities Subjected to Natural Phenomena Hazard," Interim Report UCRL 15910, U.S. Department of Energy, Lawrence Livermore National Laboratory, Livermore, California.

Lee, A.J.H., 1973: A General Study of Tornado Generated Missiles, ASCE Specialty Conference on Structural Design of Nuclear Power Plant Facilities, Chicago, IL.

Lewellen, W.S., 1976: "Theoretical Models of the Tornado Vortex," Proceeding of the Symposium on Tornadoes, Assessment of Knowledge and Implications for Man, Texas Tech University, Lubbock, TX. 
Lindgren, B.W., 1982: Statistical Theory, Second Edition, The Macmillan Company, New York, Collier-Macmillan I imited, Iondon.

?Luan, P-H, 1987: Estimate of Missile speeds in Tornadoes, MS Thesis in Civil Engineering, Txas Tech University, Lubbock, TX.

Malaeb, D.A., 1980: Simulation of Tornado-Generated Missiles, MS Thesis in Civil Engineering, Texas Tech University, Lubbock, TX.

?Mantu, E.H., Jr., Beckerly, J.g., and Sanders, K.E., 1974: Technical Basis for Interim Regional tornado Criteria, WASH-1300, U.S. Nuclear Regulatory Commission, Washington, DC.

McDonald, James R., 1976. "Tornado Generated Missiles and Their Effects," Symposium on Tornadoes: Assessment of Knowledge and Implications for Man, Texas Tech University, Lubbock, Texas.

McDonald, J.R., 1981: "Incredible Tornado-Generated Missiles," Proceedings, $4^{\text {th }}$ U.S. National Conference on Wind Engineering Research, Vol. I, pp. 29-36, University of Washington, Seattle, WA.

McDonald J.R., 1983: A Methodology for Tornadoes Hazard Probability Assessment, prepared for Nuclear Regulatory Commission, Institute for Disaster Research, Texas Tech University, Lubbock, TX.

McDonald, J.R., 1985: "Extreme Winds and Tornadoes," Design and Evaluation of Building and Structures, Institute for Disaster Research, Texas Tech University, Lubbock, TX.

McDonald, J.R., and Norville, H.S., 1981: Potential Tornado Missiles at the Water Pit Facility, Puget South Naval Shipyard, Bremerton, Washington, prepared for Vitro Engineering Corporation, Richland, WA.

Mehta, Kishor C., Minor, Joseph E., and McDonald, James R., 1975. "Interim Guidelines for Building Occupant Protection from Tornadoes and Extreme Winds," Document TR83A prepared by the Civil Defence Preparedness Agency, Baltimore, Maryland.

Minor, J.E., Mehta, K.C., and McDonald, J.R., 1977: The Tornado: An EngineeringOriented Perspective, NOAA Technical Memorandum, ERL NSSL-82, National Severe Storms Laboratory, Norman, OK.

NRC, 1975: Missiles Generated by Natural Phenomena, U.S. Nuclear Regulatory Commission, Standard Review Plan, Revision 1, Office of Nuclear Reactor Regulation, Washington, DC. 
Paddleford, D.F., 1969: Characteristics of Tornado Generated Missiles, Nuclear Energy System, Westinghouse Electric Corporation, WCAP-7897.

Ravindra, M.K., and Nafdag, A.M., (with contributions from J.R., McDonald)., 1990: State-of -the Art and Current Research Activities in Extreme Winds Relating to Design and Evaluations of Nuclear Power Plants, NUREG/CR 5497 Office of Nuclear Regulatory Research, U.S. Nuclear Regulatory Commission, Washington, DC.

Redmann, G.H., Radbill, J.R., Marte, J.E., Degarabedian, P., and Fendell, F.E., 1976: Wind Field and Trajectory Models for Tornado Propelled Objects, Electrical Power Research Institute, Technical Report 1, Palo Alto, CA.

Simiu, E. and Cordes, M., 1976: Tornado Borne Missile Speeds, Institute for Basic Standards, National Bureau of Standards, prepared for the U.S. NRC, Washington, DC.

Plummer, H.C., 1962. Brick and Tile Engineering, Brick Institute of America, McLean, Virginia.

Rotz, J.V., 1975. "Results of Missile Impact Tests on Reinforced Concrete Panels," ASCE Specialty Conference on Structural Design of Nuclear Plant Facilities, Volume 1-A, New Orleans, Louisiana.

Stephenson, A.E., June, 1975. "Tornado Vulnerability of Nuclear Productin Facilities," Interim Report prepared by the Environmental Test Department, Sandia Laboratories, Tonapah, Nevada.

Stephenson, A.E., July, 1977. "Full-Scale Tornado Missile Impact Tests," Electrical Power Research Institute, Final Report, Project No. 399, Sandia Laboratories, Tonopah, Nevada.

Twisdale, L.A. and Dunn, W.L., 1981: Tormado Missile Simulation and Design Methodology, EPRI NP-2005, Electrical Power Research Institute, Palo Alto, CA.

USNRC, 1971: Design Basis Tornado for Nuclear Power Plants, Regulatory Guide 1.76, Directorate of Regulatory Standards, Washington, Dc.

USNRC, 1975: Standard Review Plan, Office of Nuclear Reactor Regulations, U.S. Nuclear Regulatory Commission, Washington, DC.

Vassallo, F.A., 1975. "Missile Impact Testing of Reinforced Concrete Panels," Calspan Corporation, Report No. HC-5609-D-1, Buffalo, New York.

Walpole, R.E. and Myers, R.H., 1985: Probability and Statistics for Engineers and Scientists, Third Edition, Macmillan Publishing Company, New York, NY. 
White, Bradford L., 1986. "Impact Resistance of Concrete Masonry Walls to Tornado. Generated Missiles," Master's Thesis, Department of Civil Engineering, Texas Tech University, Lubbock, Texas. 


\title{
APPENDIX A \\ DISTRUBUTION OF TIMBER MISSILES TABLES:
}

\author{
A-1 Hubbard, Texas Tornado (F2) \\ A-2 Sweetwater, Texas Tornado (F3) \\ A-3 Wichita Falls, Tornado (F4)
}


Table A-1. Missile Data for Hubbard, Texas Tornado (F2)

\begin{tabular}{|c|c|c|c|c|}
\hline Missile No. & $\begin{array}{c}\text { Length } \\
\text { (ft.) }\end{array}$ & $\begin{array}{l}\text { Width } \\
\text { (in.) }\end{array}$ & $\begin{array}{l}\text { Equiv. } \\
\text { Thick. } \\
\text { (in.) }\end{array}$ & $\begin{array}{c}\text { Weight } \\
\text { (Ib.) }\end{array}$ \\
\hline 1 & 8.16 & 4.92 & 1.53 & 13.32 \\
\hline 2 & 6.12 & 4.08 & 1.54 & 8.32 \\
\hline 3 & 4.08 & 2.40 & 1.57 & 3.33 \\
\hline 4 & 4.08 & 2.40 & 1.57 & 3.33 \\
\hline 5 & 2.72 & 4.08 & 1.54 & 3.70 \\
\hline 6 & 4.76 & 3.24 & 1.55 & 5.18 \\
\hline 7 & 8.84 & 5.76 & 1.53 & 16.83 \\
\hline 8 & 3.74 & 6.48 & 1.03 & 5.43 \\
\hline 9 & 10.20 & 6.48 & 1.03 & 14.82 \\
\hline 10 & 3.40 & 4.08 & 1.54 & 4.62 \\
\hline 11 & 8.16 & 2.40 & 1.58 & 6.70 \\
\hline 12 & 3.06 & 2.88 & 1.52 & 2.91 \\
\hline 13 & 3.40 & 6.48 & 1.03 & 4.94 \\
\hline 14 & 4.08 & 4.08 & 1.54 & 5.55 \\
\hline 15 & 3.40 & 4.92 & 1.53 & 5.55 \\
\hline 16 & 5.44 & 3.24 & 1.55 & 5.92 \\
\hline 17 & 6.80 & 3.24 & 1.55 & 7.40 \\
\hline 18 & 5.78 & 5.76 & 1.53 & 11.01 \\
\hline 19 & 3.74 & 4.08 & 1.54 & 5.10 \\
\hline 20 & 6.12 & 3.24 & 1.56 & 6.70 \\
\hline 21 & 8.84 & 2.40 & 1.57 & 7.21 \\
\hline 22 & 6.80 & 7.32 & 1.03 & 11.11 \\
\hline 23 & 3.06 & 7.32 & 1.03 & 5.00 \\
\hline 24 & 4.08 & 4.08 & 1.54 & 5.55 \\
\hline 25 & 4.08 & 3.24 & 1.55 & 4.44 \\
\hline 26 & 3.40 & 3.24 & 1.55 & 3.70 \\
\hline 27 & 5.44 & 2.40 & 1.57 & 4.44 \\
\hline 28 & 2.72 & 3.24 & 1.55 & 2.96 \\
\hline 29 & 3.40 & 2.40 & 1.57 & 2.77 \\
\hline 30 & 4.76 & 2.40 & 1.57 & 3.88 \\
\hline 31 & 4.76 & 3.24 & 1.56 & 5.20 \\
\hline 32 & 4.76 & 3.24 & 1.56 & 5.20 \\
\hline 33 & 5.44 & 3.24 & 1.55 & 5.92 \\
\hline 34 & 2.72 & 4.92 & 1.53 & 4.44 \\
\hline 35 & 8.84 & 6.48 & 1.03 & 12.84 \\
\hline 36 & 3.40 & 4.08 & 1.54 & 4.62 \\
\hline 37 & 4.76 & 3.24 & 1.55 & 5.18 \\
\hline 38 & 6.80 & 8.16 & 1.54 & 18.50 \\
\hline 39 & 7.48 & 5.76 & 1.53 & 14.24 \\
\hline 40 & 8.16 & 4.08 & 1.54 & 11.10 \\
\hline
\end{tabular}


Table A-1 Missile Data for Hubbard, Texas Tornado (F2) (cont.)

\begin{tabular}{|c|c|c|c|c|}
\hline Missile No. & $\begin{array}{c}\text { Length } \\
\text { (ft.) }\end{array}$ & $\begin{array}{c}\text { Width } \\
\text { (in.) }\end{array}$ & $\begin{array}{c}\text { Equiv. } \\
\text { Thick. } \\
\text { (in.) }\end{array}$ & $\begin{array}{c}\text { Weight } \\
\text { (Ib.) }\end{array}$ \\
\hline & & & & \\
$\mathbf{4 1}$ & 9.52 & 4.92 & 1.53 & 15.54 \\
$\mathbf{4 2}$ & 4.76 & 4.92 & 1.53 & 7.77 \\
$\mathbf{4 3}$ & 8.84 & 4.08 & 1.54 & 12.02 \\
$\mathbf{4 4}$ & 6.80 & 6.48 & 1.03 & 9.88 \\
$\mathbf{4 5}$ & 6.80 & 5.76 & 1.53 & 12.95 \\
$\mathbf{4 6}$ & 3.06 & 4.92 & 1.53 & 4.99 \\
$\mathbf{4 7}$ & 5.44 & 5.76 & 1.53 & 10.36 \\
$\mathbf{4 8}$ & 10.88 & 8.16 & 1.03 & 19.75 \\
$\mathbf{4 9}$ & 3.40 & 7.32 & 1.03 & 5.55 \\
$\mathbf{5 0}$ & $\mathbf{6 . 1 2}$ & 5.76 & 1.53 & 11.65 \\
$\mathbf{5 1}$ & 6.12 & 3.24 & 1.55 & 6.66 \\
$\mathbf{5 2}$ & 3.40 & 3.24 & 1.55 & 3.70 \\
$\mathbf{5 3}$ & 4.08 & 5.76 & 1.53 & 7.77 \\
$\mathbf{5 4}$ & 4.76 & 3.24 & 1.55 & 5.18 \\
$\mathbf{5 5}$ & 5.44 & 7.32 & 1.03 & 8.89 \\
$\mathbf{5 6}$ & 6.46 & 6.48 & 1.03 & 9.38 \\
$\mathbf{5 7}$ & 8.16 & 7.32 & 1.03 & 13.33 \\
$\mathbf{5 8}$ & 3.40 & 6.48 & 1.03 & 4.94 \\
$\mathbf{5 9}$ & 4.08 & 3.24 & 1.55 & 4.44 \\
$\mathbf{6 0}$ & 5.44 & 3.24 & 1.55 & 5.92 \\
$\mathbf{6 1}$ & 3.40 & 7.32 & 1.03 & 5.56 \\
$\mathbf{6 2}$ & 10.20 & 4.92 & 1.53 & 16.65 \\
$\mathbf{6 3}$ & 7.48 & 5.76 & 1.53 & 14.24 \\
$\mathbf{6 4}$ & 4.08 & 2.40 & 1.57 & 3.33 \\
$\mathbf{6 5}$ & 4.76 & 4.92 & 1.53 & 7.77 \\
$\mathbf{6 6}$ & 4.42 & 6.48 & 1.03 & 6.42 \\
$\mathbf{6 7}$ & 3.40 & 4.92 & 1.53 & 5.55 \\
$\mathbf{6 8}$ & 6.12 & 3.24 & 1.55 & 6.66 \\
$\mathbf{6 9}$ & 4.08 & 3.24 & 1.55 & 4.44 \\
$\mathbf{7 0}$ & 6.12 & 5.76 & 1.53 & 11.65 \\
& & & & \\
$\mathbf{A v e r a g e}$ & $\mathbf{5 . 4 4}$ & & & $\mathbf{7 . 7 4}$ \\
& & & & \\
\hline
\end{tabular}


Table A-2 Missile Data for Sweetwater, Texas Tornado (F3)

\begin{tabular}{|c|c|c|c|c|}
\hline Missile No. & $\begin{array}{c}\text { Length } \\
\text { (ft.) }\end{array}$ & $\begin{array}{c}\text { Width } \\
\text { (in.) }\end{array}$ & $\begin{array}{c}\text { Equiv. } \\
\text { Thick. } \\
\text { (in.) }\end{array}$ & $\begin{array}{c}\text { Weight } \\
\text { (Ib.) }\end{array}$ \\
\hline 1 & 9.65 & 10.56 & 1.02 & 22.61 \\
\hline 2 & 9.21 & 7.92 & 1.03 & 16.20 \\
\hline 3 & 10.53 & 9.48 & 1.03 & 22.20 \\
\hline 4 & 10.53 & 9.96 & 1.03 & 23.43 \\
\hline 5 & 7.68 & 6.36 & 1.02 & 10.79 \\
\hline 6 & 7.02 & 8.40 & 1.03 & 13.20 \\
\hline 7 & 8.34 & 9.96 & 1.03 & 18.55 \\
\hline 8 & 12.30 & 4.68 & 1.56 & 19.40 \\
\hline 9 & 8.34 & 3.72 & 1.52 & 10.24 \\
\hline 10 & 11.41 & 3.12 & 1.56 & 12.01 \\
\hline 11 & 9.65 & 3.72 & 1.52 & 11.85 \\
\hline 12 & 10.09 & 3.12 & 1.56 & 10.62 \\
\hline 13 & 8.77 & 4.68 & 1.56 & 13.86 \\
\hline 14 & 6.14 & 5.28 & 1.02 & 7.19 \\
\hline 15 & 5.26 & 4.68 & 1.56 & 8.31 \\
\hline 16 & 4.39 & 5.28 & 1.02 & 5.14 \\
\hline 17 & 4.83 & 4.20 & 1.54 & 6.77 \\
\hline 18 & 5.26 & 3.12 & 1.56 & 5.54 \\
\hline 19 & 4.83 & 5.76 & 1.03 & 6.22 \\
\hline 20 & 4.39 & 5.28 & 1.02 & 5.14 \\
\hline 21 & 4.83 & 5.28 & 1.02 & 5.65 \\
\hline 22 & 15.79 & 5.28 & 1.02 & 18.50 \\
\hline 23 & 7.90 & 3.12 & 1.56 & 8.31 \\
\hline 24 & 6.14 & 4.20 & 1.54 & 8.62 \\
\hline 25 & 4.83 & 3.72 & 1.52 & 5.93 \\
\hline 26 & 10.97 & 3.12 & 1.56 & 11.55 \\
\hline 27 & 13.16 & 3.72 & 1.52 & 16.17 \\
\hline 28 & 7.90 & 3.12 & 1.56 & 8.31 \\
\hline 29 & 7.90 & 5.28 & 1.02 & 9.25 \\
\hline 30 & 8.77 & 4.20 & 1.54 & 12.32 \\
\hline 31 & 9.65 & 3.72 & 1.52 & 11.86 \\
\hline 32 & 4.83 & 5.76 & 1.03 & 6.22 \\
\hline 33 & 9.21 & 4.20 & 1.54 & 12.93 \\
\hline 34 & 7.46 & 5.76 & 1.03 & 9.61 \\
\hline 35 & 12.72 & 3.12 & 1.56 & 13.40 \\
\hline 36 & 7.02 & 4.20 & 1.54 & 9.85 \\
\hline 37 & 6.58 & 3.72 & 1.53 & 8.10 \\
\hline 38 & 13.16 & 2.64 & 1.53 & 11.55 \\
\hline 39 & 5.70 & 7.32 & 1.03 & 9.35 \\
\hline 40 & 8.77 & 4.20 & 1.54 & 12.32 \\
\hline 41 & 6.58 & 3.72 & 1.52 & 8.08 \\
\hline 42 & 4.83 & 4.68 & 1.56 & 7.62 \\
\hline 43 & 4.39 & 4.68 & 1.56 & 6.93 \\
\hline 44 & 4.83 & 3.72 & 1.52 & 5.93 \\
\hline 45 & 7.46 & 4.20 & 1.54 & 10.47 \\
\hline 46 & 8.34 & 3.72 & 1.52 & 10.24 \\
\hline 47 & 5.26 & 5.28 & 1.03 & 6.17 \\
\hline 48 & 4.39 & 5.28 & 1.02 & 5.14 \\
\hline 49 & 7.90 & 3.72 & 1.52 & 9.70 \\
\hline 50 & 5.27 & 2.64 & 1.53 & 4.62 \\
\hline
\end{tabular}


Table A-2 Missile Data for Sweetwater, Texas Tornado (F3) (cont.)

\begin{tabular}{|c|c|c|c|c|}
\hline Missile No. & $\begin{array}{l}\text { Length } \\
\text { (ft.) }\end{array}$ & $\begin{array}{l}\text { Width } \\
\text { (in.) }\end{array}$ & $\begin{array}{c}\text { Equiv. } \\
\text { Thick. } \\
\text { (in.) }\end{array}$ & $\begin{array}{c}\text { Weight } \\
\text { (Ib.) }\end{array}$ \\
\hline 51 & 5.70 & 5.28 & 1.02 & 6.68 \\
\hline 52 & 6.14 & 3.12 & 1.56 & 6.47 \\
\hline 53 & 3.95 & 3.12 & 1.56 & 4.16 \\
\hline 54 & 6.14 & 3.72 & 1.52 & 7.54 \\
\hline 55 & 6.14 & 5.28 & 1.02 & 7.19 \\
\hline 56 & 6.14 & 4.68 & 1.56 & 9.70 \\
\hline 57 & 6.58 & 3.72 & 1.53 & 8.10 \\
\hline 58 & 4.56 & 3.48 & 1.53 & 5.25 \\
\hline 59 & 3.80 & 3.60 & 1.56 & 4.62 \\
\hline 60 & 4.56 & 1.80 & 1.56 & 2.77 \\
\hline 61 & 3.80 & 5.52 & 1.52 & 6.93 \\
\hline 62 & 5.32 & 3.24 & 1.52 & 5.66 \\
\hline 63 & 4.56 & 4.56 & 1.54 & 6.93 \\
\hline 64 & 4.56 & 2.76 & 1.54 & 4.20 \\
\hline 65 & 2.66 & 3.60 & 1.56 & 3.24 \\
\hline 66 & 3.80 & 7.32 & 1.02 & 6.17 \\
\hline 67 & 3.04 & 3.60 & 1.56 & 3.70 \\
\hline 68 & 6.46 & 3.24 & 0.85 & 3.87 \\
\hline 69 & 4.95 & 6.36 & 0.15 & 1.03 \\
\hline 70 & 3.04 & 4.56 & 1.54 & 4.62 \\
\hline 71 & 3.04 & 4.08 & 1.54 & 4.15 \\
\hline 72 & 2.66 & 3.60 & 1.56 & 3.24 \\
\hline 73 & 4.56 & 3.60 & 1.56 & 5.55 \\
\hline 74 & 2.66 & 3.60 & 1.56 & 3.24 \\
\hline 75 & 4.56 & 3.48 & 1.53 & 5.25 \\
\hline 76 & 3.04 & 5.52 & 1.53 & 5.55 \\
\hline 77 & 3.80 & 6.36 & 1.03 & 5.40 \\
\hline 78 & 3.04 & 2.76 & 1.52 & 2.77 \\
\hline 79 & 3.04 & 8.16 & 1.03 & 5.55 \\
\hline 80 & 2.66 & 6.36 & 1.03 & 3.78 \\
\hline 81 & 5.32 & 3.60 & 1.56 & 6.47 \\
\hline 82 & 3.04 & 6.36 & 1.03 & 4.32 \\
\hline 83 & 4.56 & 3.60 & 1.56 & 5.55 \\
\hline 84 & 2.28 & 5.52 & 1.54 & 4.20 \\
\hline 85 & 2.28 & 8.16 & 1.03 & 4.16 \\
\hline 86 & 2.66 & 2.76 & 1.53 & 2.43 \\
\hline 87 & 2.66 & 3.60 & 1.56 & 3.24 \\
\hline 88 & 3.04 & 8.16 & 1.03 & 5.55 \\
\hline Average & 6.20 & & & 8.32 \\
\hline
\end{tabular}


Table A-3 Missile Data for Wichita Falls, Texas Tornado (F4)

\begin{tabular}{|c|c|c|c|c|}
\hline Missile No. & $\begin{array}{l}\text { Length } \\
\text { (ft.) }\end{array}$ & $\begin{array}{l}\text { Width } \\
\text { (in.) }\end{array}$ & $\begin{array}{l}\text { Equiv. } \\
\text { Thick. } \\
\text { (in.) }\end{array}$ & $\begin{array}{c}\text { Weight } \\
\text { (Ib.) }\end{array}$ \\
\hline 1 & 6.15 & 2.64 & 1.54 & 5.40 \\
\hline 2 & 6.53 & 3.48 & 1.55 & 7.62 \\
\hline 3 & 9.22 & 3.96 & 1.53 & 12.13 \\
\hline 4 & 4.61 & 6.12 & 1.54 & 9.43 \\
\hline 5 & 11.53 & 4.44 & 1.52 & 16.83 \\
\hline 6 & 4.61 & 6.12 & 0.77 & 4.71 \\
\hline 7 & 6.53 & 6.12 & 0.77 & 6.68 \\
\hline 8 & 4.61 & 3.48 & 1.55 & 5.38 \\
\hline 9 & 7.69 & 6.96 & 0.77 & 8.98 \\
\hline 10 & 11.53 & 7.92 & 0.77 & 15.16 \\
\hline 11 & 10.73 & 4.44 & 1.52 & 15.66 \\
\hline 12 & 6.92 & 4.44 & 1.52 & 10.10 \\
\hline 13 & 6.15 & 4.44 & 1.52 & 8.97 \\
\hline 14 & 8.46 & 4.44 & 1.52 & 12.34 \\
\hline 15 & 6.15 & 8.76 & 0.77 & 8.99 \\
\hline 16 & 5.38 & 5.28 & 1.53 & 9.43 \\
\hline 17 & 10.76 & 7.44 & 0.77 & 13.35 \\
\hline 18 & 7.69 & 5.28 & 1.53 & 13.47 \\
\hline 19 & 5.77 & 6.96 & 0.77 & 6.74 \\
\hline 20 & 10.76 & 3.48 & 1.55 & 12.56 \\
\hline 21 & 9.22 & 6.12 & 0.77 & 9.43 \\
\hline 22 & 5.38 & 2.64 & 1.53 & 4.72 \\
\hline 23 & 4.61 & 3.48 & 1.55 & 5.38 \\
\hline 24 & 13.07 & 7.44 & 0.77 & 16.21 \\
\hline 25 & 6.15 & 9.60 & 0.77 & 9.89 \\
\hline 26 & 5.38 & 8.28 & 0.77 & 7.46 \\
\hline 27 & 5.38 & 7.92 & 0.77 & 7.08 \\
\hline 28 & 3.84 & 3.48 & 1.55 & 4.48 \\
\hline 29 & 3.84 & 7.92 & 0.77 & 5.05 \\
\hline 30 & 4.61 & 19.32 & 0.77 & 14.82 \\
\hline 31 & 15.37 & 6.96 & 0.78 & 17.97 \\
\hline 32 & 3.84 & 1.80 & 1.50 & 2.25 \\
\hline 33 & 3.08 & 0.96 & 0.77 & 3.59 \\
\hline 34 & 3.84 & 4.44 & 1.52 & 5.61 \\
\hline 35 & 3.84 & 6.96 & 0.78 & 4.49 \\
\hline 36 & 7.69 & 2.64 & 1.53 & 6.75 \\
\hline 37 & 8.47 & 6.96 & 0.77 & 9.88 \\
\hline 38 & 12.30 & 7.92 & 0.77 & 16.17 \\
\hline 39 & 5.38 & 6.12 & 0.77 & 5.50 \\
\hline 40 & 4.61 & 3.96 & 1.53 & 6.06 \\
\hline 41 & 4.61 & 6.12 & 0.77 & 4.71 \\
\hline 42 & 4.10 & 9.60 & 0.94 & 8.03 \\
\hline 43 & 10.76 & 4.44 & 1.52 & 15.70 \\
\hline 44 & 8.47 & 7.92 & 0.77 & 11.12 \\
\hline 45 & 3.84 & 4.44 & 1.52 & 5.61 \\
\hline 46 & 5.38 & 4.44 & 1.52 & 7.87 \\
\hline 47 & 6.15 & 8.76 & 0.77 & 8.99 \\
\hline 48 & 6.92 & 4.44 & 1.52 & 10.10 \\
\hline 49 & 3.84 & 9.60 & 0.77 & 6.18 \\
\hline 50 & 4.61 & 4.44 & 1.52 & 6.73 \\
\hline
\end{tabular}


Table A-3 Missile Data for Wichita Falls Texas Tornado (F4) (cont.)

\begin{tabular}{|c|c|c|c|c|}
\hline Missile No. & $\begin{array}{l}\text { Length } \\
\text { (ft.) }\end{array}$ & $\begin{array}{c}\text { Width } \\
\text { (in.) }\end{array}$ & $\begin{array}{l}\text { Equiv. } \\
\text { Thick. } \\
\text { (in.) }\end{array}$ & $\begin{array}{c}\text { Weight } \\
\text { (Ih.) }\end{array}$ \\
\hline 51 & 2.31 & 11.40 & 0.95 & 4.38 \\
\hline 52 & 6.15 & 6.12 & 0.93 & 6.29 \\
\hline 53 & 11.53 & 3.48 & 1.40 & 13.45 \\
\hline 54 & 7.69 & 9.60 & 0.59 & 12.36 \\
\hline 55 & 5.38 & 6.96 & 2.07 & 6.29 \\
\hline 56 & 6.92 & 9.60 & 0.33 & 11.12 \\
\hline 57 & 5.38 & 4.44 & 1.29 & 7.85 \\
\hline 58 & 3.84 & 4.44 & 1.46 & 5.61 \\
\hline 59 & 5.38 & 4.44 & 1.74 & 7.85 \\
\hline 60 & 10.76 & 4.44 & 1.46 & 15.70 \\
\hline 61 & 13.84 & 6.12 & 0.85 & 14.14 \\
\hline 62 & 4.61 & 7.92 & 1.28 & 6.06 \\
\hline 63 & 6.15 & 4.44 & 1.52 & 8.97 \\
\hline 64 & 6.15 & 4.44 & 2.09 & 8.97 \\
\hline 65 & 4.61 & 4.44 & 2.03 & 6.73 \\
\hline 66 & 3.84 & 4.44 & 2.55 & 5.61 \\
\hline 67 & 6.20 & 5.28 & 1.88 & 10.86 \\
\hline 68 & 6.15 & 5.28 & 1.91 & 10.77 \\
\hline 69 & 2.69 & 6.96 & 1.66 & 3.14 \\
\hline 70 & 13.84 & 6.96 & 0.60 & 16.17 \\
\hline 71 & 10.76 & 9.60 & 0.42 & 17.30 \\
\hline 72 & 4.61 & 4.44 & 1.06 & 6.73 \\
\hline 73 & 5.38 & 3.48 & 1.33 & 6.28 \\
\hline 74 & 5.38 & 5.28 & 2.63 & 9.43 \\
\hline 75 & 6.92 & 6.96 & 0.95 & 8.08 \\
\hline 76 & 6.92 & 4.44 & 1.12 & 5.05 \\
\hline 77 & 6.92 & 8.76 & 0.54 & 10.11 \\
\hline 78 & 6.92 & 8.76 & 0.34 & 10.11 \\
\hline 79 & 3.08 & 7.92 & 0.96 & 4.04 \\
\hline 80 & 6.92 & 7.44 & 1.33 & 8.58 \\
\hline 81 & 14.61 & 7.92 & 0.72 & 19.20 \\
\hline 82 & 11.53 & 7.92 & 0.11 & 15.16 \\
\hline 83 & 17.68 & 9.60 & 0.10 & 28.42 \\
\hline 84 & 8.46 & 7.92 & 0.39 & 11.12 \\
\hline 85 & 6.15 & 6.96 & 0.48 & 7.19 \\
\hline 86 & 8.46 & 6.96 & 0.53 & 9.88 \\
\hline 87 & 7.67 & 6.96 & 0.85 & 8.96 \\
\hline 88 & 3.84 & 6.96 & 2.79 & 4.49 \\
\hline 89 & 6.15 & 6.96 & 0.59 & 7.19 \\
\hline 90 & 6.20 & 8.76 & 0.51 & 9.06 \\
\hline 91 & 5.38 & 7.92 & 0.51 & 7.08 \\
\hline 92 & 6.15 & 6.96 & 0.87 & 7.19 \\
\hline 93 & 8.46 & 8.76 & 0.98 & 12.36 \\
\hline 94 & 3.84 & 8.76 & 1.53 & 5.62 \\
\hline 95 & 4.61 & 4.44 & 1.26 & 6.73 \\
\hline 96 & 6.92 & 5.28 & 0.99 & 12.12 \\
\hline 97 & 5.39 & 5.28 & 1.46 & 9.43 \\
\hline 98 & 6.92 & 5.28 & 1.28 & 12.12 \\
\hline 99 & 6.15 & 7.92 & 0.59 & 8.09 \\
\hline 100 & 9.22 & 7.92 & 0.43 & 12.13 \\
\hline
\end{tabular}


Table A-3 Missile Data for Wichita Falls Texas Tornado (F4) (cont.)

\begin{tabular}{|c|c|c|c|c|}
\hline Missile No. & $\begin{array}{l}\text { Length } \\
\text { (ft.) }\end{array}$ & $\begin{array}{l}\text { Width } \\
\text { (in.) }\end{array}$ & $\begin{array}{l}\text { Equiv. } \\
\text { Thick. } \\
\text { (in.) }\end{array}$ & $\begin{array}{c}\text { Weight } \\
\text { (Ib.) }\end{array}$ \\
\hline 101 & 3.84 & 4.44 & 1.52 & 5.61 \\
\hline 102 & 15.37 & 5.28 & 0.77 & 13.47 \\
\hline 103 & 17.68 & 4.44 & 0.76 & 12.90 \\
\hline 104 & 5.38 & 5.28 & 1.53 & 9.43 \\
\hline 105 & 7.69 & 8.76 & 0.77 & 11.23 \\
\hline 106 & 11.53 & 7.92 & 0.77 & 15.16 \\
\hline 107 & 6.15 & 6.96 & 0.78 & 7.19 \\
\hline 108 & 3.84 & 8.76 & 0.77 & 5.62 \\
\hline 109 & 4.61 & 4.44 & 1.52 & 6.73 \\
\hline 110 & 5.38 & 7.92 & 0.77 & 7.07 \\
\hline 111 & 4.61 & 6.12 & 0.77 & 4.71 \\
\hline 112 & 3.88 & 6.96 & 0.78 & 4.54 \\
\hline 113 & 11.53 & 6.12 & 0.77 & 11.79 \\
\hline 114 & 15.37 & 7.92 & 0.77 & 20.21 \\
\hline 115 & 10.76 & 6.12 & 0.77 & 11.00 \\
\hline 116 & 6.92 & 6.12 & 0.77 & 7.07 \\
\hline 117 & 15.37 & 7.92 & 0.77 & 20.21 \\
\hline 118 & 8.46 & 4.44 & 1.52 & 12.34 \\
\hline 119 & 5.38 & 6.96 & 0.78 & 6.29 \\
\hline 120 & 6.15 & 6.96 & 0.78 & 7.19 \\
\hline 121 & 7.69 & 6.12 & 0.77 & 7.86 \\
\hline 122 & 3.08 & 2.64 & 1.53 & 2.70 \\
\hline 123 & 4.61 & 6.96 & 0.78 & 5.39 \\
\hline 124 & 6.15 & 5.28 & 1.53 & 10.77 \\
\hline 125 & 5.38 & 6.96 & 0.78 & 6.29 \\
\hline 126 & 3.08 & 8.76 & 0.77 & 4.49 \\
\hline 127 & 6.92 & 8.76 & 0.77 & 10.11 \\
\hline 128 & 4.61 & 6.96 & 0.78 & 5.39 \\
\hline 129 & 3.15 & 13.20 & 0.77 & 6.90 \\
\hline 130 & 6.15 & 8.76 & 0.77 & 8.99 \\
\hline 131 & 6.92 & 8.76 & 0.77 & 10.11 \\
\hline 132 & 9.22 & 8.76 & 0.77 & 13.48 \\
\hline 133 & 5.38 & 5.28 & 1.53 & 9.43 \\
\hline 134 & 9.99 & 7.92 & 0.77 & 13.14 \\
\hline 135 & 6.92 & 8.76 & 0.77 & 10.11 \\
\hline 136 & 5.38 & 6.96 & 0.78 & 6.29 \\
\hline 137 & 4.61 & 9.60 & 0.77 & 7.41 \\
\hline 138 & 4.61 & 9.60 & 0.77 & 7.41 \\
\hline 139 & 5.38 & 4.44 & 1.52 & 7.86 \\
\hline 140 & 6.15 & 8.76 & 0.77 & 8.99 \\
\hline 141 & 4.61 & 5.28 & 1.53 & 8.08 \\
\hline 142 & 6.15 & 6.12 & 0.77 & 6.29 \\
\hline 143 & 4.61 & 6.12 & 0.77 & 4.71 \\
\hline Average & 6.94 & & & 9.20 \\
\hline
\end{tabular}




\section{APENDIX B \\ MAXIMUM SPEEDS AND HEIGHTS OF 15 POUND \\ 2X4 TIMBER MISSILE IN F3 TORNADO}

Tabulated below are calculated trajectory parameters of a $15 \mathrm{lb} 2 \times 4$ timber plank missiles that were picked up by the $\mathrm{f} 3$ tornado wind. The mean value, variance and the standard deviation are calculated from the trajectory data:

1. Numbers of missiles picked up ...... 141

2. Mean value:

$$
\begin{array}{cc}
\mathrm{n} & 141 \\
\sum \mathrm{X}_{\mathrm{i}} & \sum \mathrm{X}_{\mathrm{i}} \\
\mathrm{i}=1 & \mathrm{i}=1 \\
\mathrm{n} & \frac{\mathrm{i}=1}{141}=129
\end{array}
$$

3. Variance

$$
\begin{array}{ll}
\mathrm{n} & 141 \\
\mathrm{~S}=\frac{\mathrm{i}=1}{\mathrm{n}-1}= & \frac{\mathrm{i}=1}{140}=362
\end{array}
$$

4. Standard Deviation

$$
\sigma=(S)^{1 / 2}=(362)^{1 / 2}=19
$$

where

$\mathrm{X}_{\mathrm{i}}$ is missile horizontal speed, and

$\mathrm{n}$ is the number of missiles were picked up. 
Trajectory Parameters $15 \mathrm{lb}$. 2x4 Timber Missile, F3 Tornado

\begin{tabular}{|c|c|c|c|c|c|}
\hline $\begin{array}{l}\text { Missile } \\
\text { Spaced } \\
\text { Number }\end{array}$ & $\begin{array}{c}\text { Missile } \\
\text { Trajectory } \\
\text { Number }\end{array}$ & $\begin{array}{l}\text { Distance to } \\
\text { Tornado } \\
\text { Path (ft) }\end{array}$ & $\begin{array}{c}\text { Maximum } \\
\text { Horizontal } \\
\text { Speed (mph) }\end{array}$ & $\begin{array}{c}\text { Maximum } \\
\text { Vertical } \\
\text { Speed (mph) }\end{array}$ & $\begin{array}{l}\text { Maximum } \\
\text { Height } \\
\text { (ft) }\end{array}$ \\
\hline 1 & & 750 & & No & Release \\
\hline 2 & & 740 & & & \\
\hline 3 & & 730 & & & \\
\hline 4 & & 720 & & & \\
\hline 5 & & 710 & & & \\
\hline 6 & & 700 & & & \\
\hline 7 & & 690 & & & \\
\hline 8 & & 680 & & & \\
\hline 9 & & 670 & & & \\
\hline 10 & & 660 & & & \\
\hline 11 & & 650 & & & \\
\hline 12 & & 640 & & & \\
\hline 13 & & 630 & & & \\
\hline 14 & & 620 & & & \\
\hline 15 & & 610 & & & \\
\hline 16 & & 600 & & & \\
\hline 17 & & 590 & & & \\
\hline 18 & & 580 & & & \\
\hline 19 & & 570 & & & \\
\hline 20 & & 560 & & & \\
\hline 21 & & 550 & & & \\
\hline 22 & & 540 & & & \\
\hline 23 & & 530 & & & \\
\hline 24 & & 520 & & & \\
\hline 25 & & 510 & & & \\
\hline 26 & & 500 & & & \\
\hline 27 & & 490 & & & \\
\hline 28 & & 480 & & & \\
\hline 29 & & 470 & & & \\
\hline 30 & & 460 & & & \\
\hline 31 & & 450 & & & \\
\hline 32 & & 440 & & & \\
\hline 33 & & 430 & & & \\
\hline 34 & 1 & 420 & 181 & 36 & 200 \\
\hline 35 & 2 & 410 & 174 & 38 & 222 \\
\hline
\end{tabular}


Trajectory Parameters !5 lb. 2x4 Timber Missile, F3 Tornado continued:

\begin{tabular}{|c|c|c|c|c|c|}
\hline $\begin{array}{l}\text { Missile } \\
\text { Spaced } \\
\text { Number }\end{array}$ & $\begin{array}{c}\text { Missile } \\
\text { Trajectory } \\
\text { Number }\end{array}$ & $\begin{array}{l}\text { Distance to } \\
\text { Tornado } \\
\text { Path (ft) }\end{array}$ & $\begin{array}{c}\text { Maximum } \\
\text { Horizontal } \\
\text { Speed (mph) }\end{array}$ & $\begin{array}{c}\text { Maximum } \\
\text { Vertical } \\
\text { Speed (mph) }\end{array}$ & $\begin{array}{c}\text { Maximum } \\
\text { Height } \\
(\mathrm{ft}) \\
\end{array}$ \\
\hline 36 & 3 & 400 & 170 & 39 & 220 \\
\hline 37 & 4 & 390 & 172 & 39 & 226 \\
\hline 38 & 5 & 380 & 168 & 40 & 227 \\
\hline 39 & 6 & 370 & 167 & 40 & 229 \\
\hline 40 & 7 & 360 & 165 & 40 & 231 \\
\hline 41 & 8 & 350 & 162 & 40 & 235 \\
\hline 42 & 9 & 340 & 163 & 41 & 233 \\
\hline 43 & 10 & 330 & 161 & 41 & 238 \\
\hline 44 & 11 & 320 & 161 & 41 & 237 \\
\hline 45 & 12 & 310 & 159 & 41 & 243 \\
\hline 46 & 13 & 300 & 158 & 41 & 243 \\
\hline 47 & 14 & 290 & 157 & 41 & 243 \\
\hline 48 & 15 & 280 & 156 & 41 & 245 \\
\hline 49 & 16 & 270 & 155 & 41 & 245 \\
\hline 50 & 17 & 260 & 155 & 42 & 246 \\
\hline 51 & 18 & 250 & 154 & 42 & 248 \\
\hline 52 & 19 & 240 & 153 & 41 & 250 \\
\hline 53 & 20 & 230 & 153 & 42 & 252 \\
\hline 54 & 21 & 220 & 152 & 42 & 253 \\
\hline 55 & 22 & 210 & 153 & 41 & 256 \\
\hline 56 & 23 & 200 & 150 & 43 & 261 \\
\hline 57 & 24 & 190 & 149 & 42 & 259 \\
\hline 58 & 25 & 180 & 147 & 43 & 263 \\
\hline 59 & 26 & 170 & 145 & 42 & 266 \\
\hline 60 & 27 & 160 & 143 & 42 & 265 \\
\hline 61 & 28 & 150 & 142 & 43 & 260 \\
\hline 62 & 29 & 140 & 140 & 43 & 262 \\
\hline 63 & 30 & 130 & 139 & 42 & 264 \\
\hline 64 & 31 & 120 & 138 & 42 & 263 \\
\hline 65 & 32 & 110 & & 42 & 268 \\
\hline 66 & 33 & 100 & 136 & 43 & 270 \\
\hline 67 & 34 & 90 & 135 & 44 & 272 \\
\hline 68 & 35 & 80 & 135 & 44 & 275 \\
\hline 69 & 36 & 70 & 134 & 44 & 273 \\
\hline 70 & 37 & 60 & 133 & 42 & 275 \\
\hline
\end{tabular}


Trajectory Parameters $15 \mathrm{lb} .2 \times 4$ Timber Missile, F3 Tornado

\begin{tabular}{|c|c|c|c|c|c|}
\hline $\begin{array}{l}\text { Missile } \\
\text { Spaced } \\
\text { Number }\end{array}$ & $\begin{array}{l}\text { Missile } \\
\text { Trajectory } \\
\text { Number }\end{array}$ & $\begin{array}{c}\text { Distance to } \\
\text { T'ornado } \\
\text { Path (ft) }\end{array}$ & $\begin{array}{c}\text { Maximum } \\
\text { Horizontal } \\
\text { Speed (mph) }\end{array}$ & $\begin{array}{c}\text { Maximum } \\
\text { Vertical } \\
\text { Speed (mph) }\end{array}$ & $\begin{array}{l}\text { Maximum } \\
\text { Height } \\
\text { (ft) }\end{array}$ \\
\hline 71 & 38 & 50 & 132 & 43 & 274 \\
\hline 72 & 39 & 40 & 132 & 41 & 266 \\
\hline 73 & 40 & 30 & 131 & 41 & 263 \\
\hline 74 & 41 & 20 & 132 & 40 & 261 \\
\hline 75 & 42 & 10 & 132 & 40 & 262 \\
\hline 76 & 43 & 0 & 132 & 40 & 259 \\
\hline 77 & 44 & -10 & 132 & 40 & 261 \\
\hline 78 & 45 & -20 & 131 & 40 & 256 \\
\hline 79 & 46 & -30 & 131 & 41 & 260 \\
\hline 80 & 47 & -40 & 130 & 40 & 255 \\
\hline 81 & 48 & -50 & 130 & 40 & 253 \\
\hline 82 & 49 & -60 & 129 & 40 & 245 \\
\hline 83 & 50 & -70 & 130 & 40 & 249 \\
\hline 84 & 51 & -80 & 129 & 39 & 240 \\
\hline 85 & 52 & -90 & 128 & 39 & 244 \\
\hline 86 & 53 & -100 & 127 & 40 & 243 \\
\hline 87 & 54 & -110 & 127 & 39 & 237 \\
\hline 88 & 55 & -120 & 128 & 39 & 233 \\
\hline 89 & 56 & -130 & 127 & 39 & 230 \\
\hline 90 & 57 & -140 & 128 & 38 & 227 \\
\hline 91 & 58 & -150 & 127 & 38 & 222 \\
\hline 92 & 59 & -160 & 128 & 38 & 223 \\
\hline 93 & 60 & -170 & 127 & 38 & 219 \\
\hline 94 & 61. & -180 & 130 & 38 & 218 \\
\hline 95 & 62 & -190 & 129 & 37 & 214 \\
\hline 96 & 63 & -200 & 130 & 38 & 215 \\
\hline 97 & 64 & -210 & 129 & 37 & 211 \\
\hline 98 & 65 & -220 & 130 & 37 & 210 \\
\hline 99 & 66 & -230 & 131 & 37 & 208 \\
\hline 100 & 67 & -240 & 133 & 37 & 205 \\
\hline 101 & 68 & -250 & 132 & 37 & 207 \\
\hline 102 & 69 & -260 & 133 & 37 & 205 \\
\hline 103 & 70 & -270 & 134 & 36 & 206 \\
\hline 104 & 71 & -280 & 135 & 37 & 207 \\
\hline 105 & 72 & -290 & 136 & 37 & 204 \\
\hline
\end{tabular}


Trajectory Parameters $15 \mathrm{lb} .2 \times 4$ Timber Missile, F3 Tornado

\begin{tabular}{|c|c|c|c|c|c|}
\hline $\begin{array}{l}\text { Missile } \\
\text { Spaced } \\
\text { Number }\end{array}$ & $\begin{array}{c}\text { Missile } \\
\text { Trajectory } \\
\text { Number }\end{array}$ & $\begin{array}{c}\text { Distance to } \\
\text { Tornado } \\
\text { Path (ft) }\end{array}$ & $\begin{array}{c}\text { Maximum } \\
\text { Horizontal } \\
\text { Speed (mph) }\end{array}$ & $\begin{array}{c}\text { Maximum } \\
\text { Vertical } \\
\text { Speed (mph) }\end{array}$ & $\begin{array}{c}\text { Maximum } \\
\text { Height } \\
(\mathrm{ft}) \\
\end{array}$ \\
\hline 106 & 73 & -300 & 138 & 37 & 201 \\
\hline 107 & 74 & -310 & 138 & 37 & 198 \\
\hline 108 & 75 & -320 & 146 & 37 & 193 \\
\hline 109 & 76 & -330 & 148 & 37 & 190 \\
\hline 110 & 77 & -340 & 123 & 37 & 185 \\
\hline 111 & 78 & -350 & 122 & 38 & 180 \\
\hline 112 & 79 & -360 & 122 & 36 & 65 \\
\hline 113 & 80 & -370 & 123 & 34 & 68 \\
\hline 114 & 81 & -380 & 122 & 32 & 65 \\
\hline 115 & 82 & -390 & 121 & 29 & 63 \\
\hline 116 & 83 & -400 & 120 & 30 & 64 \\
\hline 117 & 79 & -410 & 121 & 30 & 64 \\
\hline 118 & 80 & -420 & 120 & 29 & 63 \\
\hline 119 & 81 & -430 & 119 & 29 & 63 \\
\hline 120 & 82 & -440 & 120 & 30 & 63 \\
\hline 121 & 88 & -450 & 119 & 29 & 63 \\
\hline 122 & 89 & -450 & 118 & 29 & 62 \\
\hline 123 & 90 & -470 & 119 & 29 & 63 \\
\hline 124 & 91 & -480 & 118 & 29 & 63 \\
\hline 125 & 92 & -490 & 118 & 29 & 63 \\
\hline 126 & 93 & -500 & 117 & 29 & 62 \\
\hline 127 & 94 & -510 & 117 & 29 & 61 \\
\hline 128 & 95 & -520 & 117 & 29 & 61 \\
\hline 129 & 96 & -530 & 117 & 29 & 61 \\
\hline 130 & 97 & -540 & 116 & 29 & 61 \\
\hline 131 & 98 & -550 & 116 & 29 & 62 \\
\hline 132 & 99 & -560 & 115 & 29 & 62 \\
\hline 133 & 100 & -570 & 115 & 29 & 62 \\
\hline 134 & 101 & -580 & 115 & 29 & 61 \\
\hline 135 & 102 & -590 & 114 & 29 & 61 \\
\hline 136 & 103 & -600 & 114 & 29 & 62 \\
\hline 137 & 104 & -610 & 114 & 29 & 61 \\
\hline 138 & 105 & -620 & 114 & 28 & 61 \\
\hline 139 & 106 & -630 & 114 & 29 & 61 \\
\hline 140 & 107 & -640 & 113 & 29 & 61 \\
\hline
\end{tabular}


Trajectory Parameters $15 \mathrm{lb} .2 \times 4$ Timber Missile, F3 Tornado

\begin{tabular}{|c|c|c|c|c|c|}
\hline $\begin{array}{l}\text { Missile } \\
\text { Spaced } \\
\text { Number } \\
\end{array}$ & $\begin{array}{c}\text { Missile } \\
\text { Trajectory } \\
\text { Number }\end{array}$ & $\begin{array}{l}\text { Distance to } \\
\text { Tornado } \\
\text { Path (ft) }\end{array}$ & $\begin{array}{c}\text { Maximum } \\
\text { Horizontal } \\
\text { Speed (mph) }\end{array}$ & $\begin{array}{c}\text { Maximum } \\
\text { Vertical } \\
\text { Speed (mph) }\end{array}$ & $\begin{array}{c}\text { Maximum } \\
\text { Height } \\
\text { (ft) }\end{array}$ \\
\hline 141 & 108 & -650 & 113 & 28 & 61 \\
\hline 142 & 108 & -660 & 113 & 28 & 61 \\
\hline 143 & 110 & -670 & 113 & 28 & 61 \\
\hline 144 & 111 & -680 & 112 & 28 & 61 \\
\hline 145 & 112 & -690 & 112 & 28 & 60 \\
\hline 146 & 113 & -700 & 111 & 28 & 60 \\
\hline 147 & 114 & -710 & 111 & 28 & 60 \\
\hline 148 & 115 & -720 & 111 & 28 & 59 \\
\hline 149 & 116 & -730 & 111 & 28 & 60 \\
\hline 150 & 117 & -740 & 110 & 28 & 60 \\
\hline 151 & 118 & -750 & 110 & 28 & 60 \\
\hline 152 & 119 & -760 & 109 & 27 & 60 \\
\hline 153 & 120 & -770 & 110 & 28 & 59 \\
\hline 154 & 121 & -780 & 110 & 28 & 60 \\
\hline 155 & 122 & -790 & 109 & 28 & 60 \\
\hline 156 & 123 & -800 & 109 & 28 & 60 \\
\hline 157 & 124 & -810 & 109 & 28 & 60 \\
\hline 158 & 125 & -820 & & 28 & 60 \\
\hline 159 & 126 & -830 & 108 & 28 & 59 \\
\hline 160 & 127 & -840 & 108 & 28 & 59 \\
\hline 161 & 128 & -850 & 108 & 28 & 59 \\
\hline 162 & 129 & -860 & 108 & 28 & 59 \\
\hline 163 & 130 & -870 & 107 & 29 & 59 \\
\hline 164 & 131 & -880 & 107 & 28 & 59 \\
\hline 165 & 132 & -890 & 106 & 29 & 59 \\
\hline 166 & 133 & -900 & 106 & 28 & 59 \\
\hline 167 & 134 & -910 & 106 & 28 & 59 \\
\hline 168 & 135 & -920 & $\overline{106}$ & 29 & 58 \\
\hline 169 & 136 & -930 & 106 & 29 & 58 \\
\hline 170 & 137 & -940 & 105 & 29 & 58 \\
\hline 171 & 138 & -950 & 105 & 29 & 58 \\
\hline 172 & 139 & -960 & 105 & 28 & 58 \\
\hline 173 & 140 & -970 & 105 & 28 & 58 \\
\hline 174 & 141 & -980 & 104 & 28 & 58 \\
\hline $\begin{array}{l}175 \\
176 \\
177\end{array}$ & & $\begin{array}{l}-990 \\
-1000 \\
-1010\end{array}$ & & No & Release \\
\hline
\end{tabular}




\section{APPENDIX C \\ MAXIMUM SPEEDS AND HEIGHTS OF \\ 3 IN. DIA. STEEI. PIPE IN F5 TORNADO}

Tabulated below are calculated trajectory parameter of $3 \mathrm{in}$. diameter steel pipe missiles that were picked up by the $\mathrm{F} 5$ tornado wind. The mean value variance and the standard deviation are calculated from the trajectory data as follows:

1. Numbers of missiles were picked up ...... 256

2. Mean value

$$
\begin{aligned}
& \text { n } 256 \\
& \sum \mathrm{X}_{\mathrm{i}} \quad \sum \mathrm{X}_{\mathrm{i}} \\
& \mu=\frac{\mathrm{i}=1}{\mathrm{n}}=\frac{\mathrm{i}=1}{256}=78
\end{aligned}
$$

3. Variance

$$
\begin{gathered}
\mathrm{n} \\
\mathrm{S}=\frac{\mathrm{i}=1}{\mathrm{n}-1} \\
256 \\
=\frac{\mathrm{i}\left(\mathrm{X}_{\mathrm{i}}-\mu\right)^{2}}{255}=38
\end{gathered}
$$


4. Standard deviation

$\sigma=(S)^{1 / 2}=(38)^{1 / 2}=6$

where

$\mathrm{X}_{\mathrm{i}}$ is missile horizontal speed, and

$\mathrm{n} \quad$ is the number of missiles were picked up. 
Trajectory Parameters 3 in. Diameter steel Pipe F5 Tornado

\begin{tabular}{|c|c|c|c|c|c|}
\hline $\begin{array}{l}\text { Missile } \\
\text { Spaced } \\
\text { Number }\end{array}$ & $\begin{array}{l}\text { Missile } \\
\text { Trajectory } \\
\text { Number }\end{array}$ & $\begin{array}{l}\text { Distance to } \\
\text { Tornado } \\
\text { Path (ft) }\end{array}$ & $\begin{array}{l}\text { Maximum } \\
\text { Horizontal } \\
\text { Speed (mph) }\end{array}$ & $\begin{array}{l}\text { Maximum } \\
\text { Vertical } \\
\text { Speed (mph) }\end{array}$ & $\begin{array}{l}\text { Maximum } \\
\text { Height } \\
(\mathrm{ft})\end{array}$ \\
\hline 1 & & 1950 & & No & Release \\
\hline 2 & & 1940 & & . &. \\
\hline 3 & & 1930 & & . & . \\
\hline 4 & & 1920 & & . & . \\
\hline 5 & & 1920 & & . & - \\
\hline 6 & & 1900 & & . & . \\
\hline 7 & & 1890 & & . & . \\
\hline 8 & & 1880 & & . & . \\
\hline 9 & & 1870 & & . & . \\
\hline 10 & & 1860 & & . & . \\
\hline 11 & & 1850 & & . & . \\
\hline 12 & & 1840 & & . & . \\
\hline 13 & & 1830 & & . & . \\
\hline 14 & & 1820 & & . & . \\
\hline 15 & & 1810 & & . & . \\
\hline 16 & & 1800 & & . & . \\
\hline 17 & & 1790 & & . & . \\
\hline 18 & & 1780 & & . & . \\
\hline 19 & & 1770 & & . & . \\
\hline 20 & & 1760 & & $\cdot$ & . \\
\hline 21 & & 1750 & & . & . \\
\hline 22 & & 1740 & & . & . \\
\hline 23 & & 1730 & & . & . \\
\hline 24 & & 1720 & & • & . \\
\hline 25 & & 1710 & & $\cdot$ & $\cdot$ \\
\hline 26 & & 1700 & & . & . \\
\hline 27 & & 1690 & & • & . \\
\hline 28 & & 1680 & & . & . \\
\hline 29 & & 1670 & & . & . \\
\hline 30 & & 1660 & & - & . \\
\hline 31 & & 1650 & & . & . \\
\hline 32 & & 1640 & & . & . \\
\hline 33 & & 1630 & & $\cdot$ & . \\
\hline 34 & & 1620 & & • & . \\
\hline 35 & & 1610 & & . & . \\
\hline
\end{tabular}


Trajectory Parameters 3-in.Diameter steel Pipe F5 Tornado continued:

\begin{tabular}{|c|c|c|c|c|c|}
\hline $\begin{array}{l}\text { Missile } \\
\text { Spaced } \\
\text { Number }\end{array}$ & $\begin{array}{l}\text { Missile } \\
\text { Trajectory } \\
\text { Number }\end{array}$ & $\begin{array}{l}\text { Distance to } \\
\text { Tornado } \\
\text { Path (ft) }\end{array}$ & $\begin{array}{l}\text { Maximum } \\
\text { Horizontal } \\
\text { Speed (mph) }\end{array}$ & $\begin{array}{l}\text { Maximum } \\
\text { Vertical } \\
\text { Speed (mph) }\end{array}$ & $\begin{array}{l}\text { Maximum } \\
\text { Height } \\
(\mathrm{ft}) \\
\end{array}$ \\
\hline 36 & & 1600 & & No Release & No Release \\
\hline 37 & & 1590 & &. &. \\
\hline 38 & & 1580 & & . & . \\
\hline 39 & & 1570 & & . & . \\
\hline 40 & & 1560 & & $\cdot$ & . \\
\hline 41 & & 1550 & & . & . \\
\hline 42 & & 1540 & & . & . \\
\hline 43 & & 1530 & & . & . \\
\hline 44 & & 1520 & & . & . \\
\hline 45 & & 1510 & & . & . \\
\hline 46 & & 1500 & & . & . \\
\hline 47 & & 1490 & & . & . \\
\hline 48 & & 1480 & & . & . \\
\hline 49 & & 1470 & & . & . \\
\hline 50 & & 1460 & & . & . \\
\hline 51 & & 1450 & & . & . \\
\hline 52 & & 1440 & & . & . \\
\hline 53 & & 1430 & & . & . \\
\hline 54 & & 1420 & & . & . \\
\hline 55 & & 1410 & & . & . \\
\hline 56 & & 1400 & & . & . \\
\hline 57 & & 1390 & & . & . \\
\hline 58 & & 1380 & & . & . \\
\hline 59 & & 1370 & & . &. \\
\hline 60 & & 1360 & & · & $\cdot$ \\
\hline 61 & & 1350 & & . & . \\
\hline 62 & & 1340 & & . & . \\
\hline 63 & & 1330 & & . & . \\
\hline 64 & & 1320 & & . & $:$ \\
\hline 65 & & 1310 & & $\cdot$ & $\cdot$ \\
\hline 66 & & 1300 & & . & . \\
\hline 67 & & 1290 & & . & . \\
\hline 68 & & 1280 & & . & . \\
\hline 69 & & 1270 & & . & . \\
\hline 70 & & 1260 & & $\therefore$ & $\cdot$ \\
\hline
\end{tabular}


Trajectory Parameters 3-in. Diameter steel Pipe F5 Tornado continued:

\begin{tabular}{|c|c|c|c|c|c|}
\hline $\begin{array}{l}\text { Missile } \\
\text { Spaced } \\
\text { Number }\end{array}$ & $\begin{array}{l}\text { Missile } \\
\text { Trajectory } \\
\text { Number }\end{array}$ & $\begin{array}{l}\text { Distance to } \\
\text { Tornado } \\
\text { Path (ft) }\end{array}$ & $\begin{array}{l}\text { Maximum } \\
\text { Horizontal } \\
\text { Speed (mph) }\end{array}$ & $\begin{array}{l}\text { Maximum } \\
\text { Vertical } \\
\text { Speed (mph) }\end{array}$ & $\begin{array}{l}\text { Maximum } \\
\text { Height } \\
\text { (ft) }\end{array}$ \\
\hline 71 & & 1250 & & No Release & No Release \\
\hline 72 & & 1240 & &. &. \\
\hline 73 & & 1230 & & . & . \\
\hline 74 & & 1220 & & . & . \\
\hline 75 & & 1210 & & . & . \\
\hline 76 & & 1200 & & . &. \\
\hline 77 & & 1190 & &. & . \\
\hline 78 & & 1180 & & . & . \\
\hline 79 & & 1170 & & . & . \\
\hline 80 & & 1160 & & - & . \\
\hline 81 & & 1150 & & . & . \\
\hline 82 & & 1140 & & . & . \\
\hline 83 & & 1130 & & . & . \\
\hline 84 & & 1120 & & . & . \\
\hline 85 & & 1110 & & · & . \\
\hline 86 & & 1100 & & . & . \\
\hline 87 & & 1090 & & . & . \\
\hline 88 & & 1080 & & . & . \\
\hline 89 & & 1070 & & . & . \\
\hline 90 & & 1060 & & . & . \\
\hline 91 & & 1050 & & . & . \\
\hline 92 & & 1040 & & . & . \\
\hline 93 & & 1030 & & . & . \\
\hline 94 & & 1020 & & . & . \\
\hline 95 & & 1010 & & . & . \\
\hline 96 & 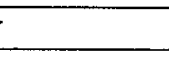 & 1000 & & . &. \\
\hline 97 & & 990 & & . & . \\
\hline 98 & & 980 & & . & . \\
\hline 99 & & 970 & & . & . \\
\hline 100 & & 960 & & . & $\cdot$ \\
\hline 101 & & 950 & & . & . \\
\hline 102 & & 940 & & . & . \\
\hline 103 & & 930 & & . & . \\
\hline 104 & 1 & 920 & 72 & 39 & 58 \\
\hline 105 & 2 & 910 & 73 & 38 & 58 \\
\hline
\end{tabular}


Trajectory Parameters 3-in.Diameter steel Pipe F5 Tornado continued:

\begin{tabular}{|c|c|c|c|c|c|}
\hline $\begin{array}{l}\text { Missile } \\
\text { Spaced } \\
\text { Number }\end{array}$ & $\begin{array}{l}\text { Missile } \\
\text { Trajectory } \\
\text { Number }\end{array}$ & $\begin{array}{l}\text { Distance to } \\
\text { Tornado } \\
\text { Path (ft) }\end{array}$ & $\begin{array}{l}\text { Maximum } \\
\text { Horizontal } \\
\text { Speed (mph) }\end{array}$ & $\begin{array}{l}\text { Maximum } \\
\text { Vertical } \\
\text { Speed (mph) }\end{array}$ & $\begin{array}{l}\text { Maximum } \\
\text { Height } \\
\text { (ft) }\end{array}$ \\
\hline 106 & 3 & 900 & 74 & 38 & 59 \\
\hline 107 & $\overline{4}$ & 890 & 75 & 38 & 59 \\
\hline 108 & 5 & 880 & 76 & 39 & 59 \\
\hline 109 & 6 & 870 & 77 & 39 & 59 \\
\hline 110 & 7 & 860 & 78 & 39 & 59 \\
\hline 111 & 8 & 850 & 79 & 39 & 59 \\
\hline 112 & 9 & 840 & 80 & 39 & 59 \\
\hline 113 & 10 & 830 & 80 & 39 & 59 \\
\hline 114 & 11 & 820 & 80 & 39 & 59 \\
\hline 115 & 12 & 810 & 81 & 38 & 59 \\
\hline 116 & 13 & 800 & 82 & 39 & 59 \\
\hline 117 & 14 & 790 & 83 & 38 & 59 \\
\hline 118 & 15 & 780 & 83 & 38 & 60 \\
\hline 119 & 16 & 770 & 83 & 38 & 60 \\
\hline 120 & 17 & 760 & 84 & 38 & 60 \\
\hline 121 & 18 & 750 & 83 & $\overline{38}$ & 60 \\
\hline 122 & 19 & 740 & 84 & 37 & 60 \\
\hline 123 & 20 & 730 & 85 & 37 & 60 \\
\hline 124 & 21 & 720 & 85 & 39 & 60 \\
\hline 125 & 22 & 710 & 86 & 38 & 60 \\
\hline 126 & $\overline{23}$ & 700 & 85 & 39 & 60 \\
\hline 127 & 24 & 690 & 87 & 38 & 60 \\
\hline 128 & 25 & 680 & 84 & & 60 \\
\hline 129 & $\overline{26}$ & 670 & 85 & $\overline{38}$ & 60 \\
\hline 130 & $\overline{27}$ & 660 & 84 & 38 & 60 \\
\hline 131 & 28 & 650 & $\overline{83}$ & 38 & 60 \\
\hline 132 & 29 & 640 & 84 & 38 & 61 \\
\hline 133 & $\overline{30}$ & 630 & 84 & 38 & 60 \\
\hline 134 & 31 & 620 & 83 & 38 & 60 \\
\hline 135 & 32 & 610 & 84 & 37 & 61 \\
\hline 136 & 33 & 600 & 83 & 38 & 60 \\
\hline 137 & 34 & 590 & 84 & 37 & 61 \\
\hline 138 & 35 & 580 & 84 & 37 & 60 \\
\hline 139 & 36 & 570 & 84 & 37 & 60 \\
\hline 140 & 37 & 560 & 83 & 38 & 60 \\
\hline
\end{tabular}


Trajectory Parameters 3-in.Diamter steel Pipe F5 Tornado continued:

\begin{tabular}{|c|c|c|c|c|c|}
\hline $\begin{array}{l}\text { Missile } \\
\text { Spaced } \\
\text { Number }\end{array}$ & $\begin{array}{l}\text { Missile } \\
\text { Trajectory } \\
\text { Number }\end{array}$ & $\begin{array}{l}\text { Distance to } \\
\text { Tornado } \\
\text { Path (ft) }\end{array}$ & $\begin{array}{l}\text { Maximum } \\
\text { Horizontal } \\
\text { Speed (mph) }\end{array}$ & $\begin{array}{l}\text { Maximum } \\
\text { Vertical } \\
\text { Speed (mph) }\end{array}$ & $\begin{array}{l}\text { Maximum } \\
\text { Height } \\
(\mathrm{ft})\end{array}$ \\
\hline 141 & 38 & 550 & 83 & 38 & 61 \\
\hline 142 & 39 & 540 & 84 & 37 & 61 \\
\hline 143 & 40 & 530 & 83 & 38 & 60 \\
\hline 144 & 41 & 520 & 83 & 38 & 61 \\
\hline 145 & 42 & 510 & 83 & 37 & 61 \\
\hline 146 & 43 & 500 & 83 & 39 & 61 \\
\hline 147 & 44 & 490 & 83 & 38 & 60 \\
\hline 148 & 45 & 480 & 83 & 38 & 61 \\
\hline 149 & 46 & 470 & 83 & 38 & 61 \\
\hline 150 & 47 & 460 & 83 & 38 & 61 \\
\hline 151 & 48 & 450 & 83 & 37 & 61 \\
\hline 152 & 49 & 440 & 84 & 39 & 61 \\
\hline 153 & 50 & 430 & 83 & 38 & 61 \\
\hline 154 & 51 & 420 & 84 & 38 & 61 \\
\hline 155 & $5 \overline{2}$ & 410 & 84 & 38 & 61 \\
\hline 156 & 53 & 400 & 83 & 39 & 60 \\
\hline 157 & 54 & 390 & 84 & 38 & 61 \\
\hline 158 & 55 & 380 & 84 & 38 & 61 \\
\hline 159 & 56 & 370 & 84 & 38 & 61 \\
\hline 160 & 57 & 360 & 85 & 38 & 61 \\
\hline 161 & 58 & 350 & 83 & 38 & 61 \\
\hline 162 & 59 & 340 & 84 & 38 & 61 \\
\hline 163 & 60 & 330 & 84 & 38 & 61 \\
\hline 164 & 61 & 320 & 84 & 38 & 61 \\
\hline 165 & 62 & 310 & 84 & 39 & 60 \\
\hline 166 & 63 & 300 & 84 & 39 & 60 \\
\hline 167 & 64 & 290 & 85 & 38 & 61 \\
\hline 168 & 65 & 280 & 85 & 38 & 61 \\
\hline 169 & 66 & 270 & 85 & 39 & 61 \\
\hline 170 & 67 & 260 & 84 & 39 & 60 \\
\hline 171 & 68 & 250 & 86 & 38 & 61 \\
\hline 172 & 69 & 240 & 85 & 39 & 61 \\
\hline 173 & 70 & 230 & 85 & 39 & 60 \\
\hline 174 & 71 & 220 & 86 & 39 & 61 \\
\hline 175 & 72 & 210 & 85 & 39 & 61 \\
\hline
\end{tabular}


Trajectory Parameters of 3-in. Dia. Steel Pipe in F5 Tornado (cont.)

\begin{tabular}{|c|c|c|c|c|c|}
\hline $\begin{array}{l}\text { Missile } \\
\text { Spaced } \\
\text { Number }\end{array}$ & $\begin{array}{l}\text { Missile } \\
\text { Trajectory } \\
\text { Number }\end{array}$ & $\begin{array}{l}\text { Distance to } \\
\text { Tornado } \\
\text { Path (ft) }\end{array}$ & $\begin{array}{l}\text { Maximum } \\
\text { Horizontal } \\
\text { Speed (mph) }\end{array}$ & $\begin{array}{l}\text { Maximum } \\
\text { Vertical } \\
\text { Speed (mph) }\end{array}$ & $\begin{array}{l}\text { Maximum } \\
\text { Height } \\
\text { (ft) }\end{array}$ \\
\hline 176 & 73 & 200 & 85 & 39 & 61 \\
\hline 177 & 74 & 190 & 86 & 39 & 61 \\
\hline 178 & 75 & 180 & 85 & 39 & 61 \\
\hline 179 & 76 & 170 & 86 & 39 & 60 \\
\hline 180 & 77 & 160 & 86 & 39 & 61 \\
\hline 181 & 78 & 150 & 85 & 40 & 61 \\
\hline 182 & 79 & 140 & 85 & 40 & 60 \\
\hline 183 & 80 & 130 & 85 & 39 & 61 \\
\hline 184 & 81 & 120 & 84 & 40 & 60 \\
\hline 185 & 82 & 11 & 86 & 40 & 61 \\
\hline 186 & 83 & 100 & 85 & 40 & 60 \\
\hline 187 & 84 & 90 & 85 & 40 & 61 \\
\hline 188 & 85 & 80 & 85 & 38 & 60 \\
\hline 189 & 86 & 70 & 85 & 40 & 61 \\
\hline 190 & 87 & 60 & 85 & 38 & 60 \\
\hline 191 & 88 & 50 & 85 & 40 & 61 \\
\hline 192 & 89 & 40 & 85 & 38 & 60 \\
\hline 193 & 90 & 30 & 85 & 40 & 60 \\
\hline 194 & 91 & 20 & 85 & 40 & 61 \\
\hline 195 & 92 & 10 & 84 & 38 & 60 \\
\hline 196 & 93 & 0 & 85 & 40 & 60 \\
\hline 197 & 94 & -10 & 84 & 39 & 61 \\
\hline 198 & 95 & -20 & 85 & 38 & 60 \\
\hline 199 & 96 & -30 & 85 & 40 & 60 \\
\hline 200 & 97 & -40 & 84 & 39 & 60 \\
\hline 201 & 98 & -50 & 84 & 38 & 60 \\
\hline 202 & 99 & -60 & 85 & 40 & 61 \\
\hline 203 & 101 & -70 & 83 & 39 & 60 \\
\hline 204 & 101 & -80 & 84 & 39 & 60 \\
\hline 205 & 102 & -90 & 84 & 38 & 60 \\
\hline 206 & 103 & -100 & 83 & 39 & 60 \\
\hline 207 & 104 & -110 & 83 & 39 & 60 \\
\hline 208 & 105 & -120 & 83 & 39 & 60 \\
\hline 209 & 106 & -130 & 84 & 38 & 61 \\
\hline 210 & 107 & -140 & 82 & 39 & 60 \\
\hline
\end{tabular}


Trajectory Paramctcrs of 3-in. Dia. Steel Pipe in F5 Tornado (cont.)

\begin{tabular}{|c|c|c|c|c|c|}
\hline $\begin{array}{l}\text { Missile } \\
\text { Spaced } \\
\text { Number } \\
\end{array}$ & $\begin{array}{l}\text { Missile } \\
\text { Trajectory } \\
\text { Number } \\
\end{array}$ & $\begin{array}{l}\text { Distance to } \\
\text { Tornado } \\
\text { Path (ft) }\end{array}$ & $\begin{array}{l}\text { Maximum } \\
\text { Horizontal } \\
\text { Speed (mph) }\end{array}$ & $\begin{array}{l}\text { Maximum } \\
\text { Vertical } \\
\text { Speed (mph) }\end{array}$ & $\begin{array}{l}\text { Maximum } \\
\text { Height } \\
\text { (ft) }\end{array}$ \\
\hline 211 & 108 & -150 & 83 & 39 & 60 \\
\hline 212 & 109 & -160 & 83 & 39 & 60 \\
\hline 213 & 110 & -170 & 83 & 38 & 60 \\
\hline 214 & 111 & -180 & 82 & 38 & 61 \\
\hline 215 & 112 & -190 & 82 & 39 & 60 \\
\hline 216 & 113 & -200 & 82 & 39 & 60 \\
\hline 217 & 114 & -210 & 82 & 39 & 60 \\
\hline 218 & 115 & -220 & 82 & 39 & 61 \\
\hline 219 & 116 & -230 & 82 & 39 & 60 \\
\hline 220 & 117 & -240 & 82 & 39 & 60 \\
\hline 221 & 118 & -250 & 81 & 39 & 60 \\
\hline 222 & 119 & -260 & 80 & 39 & 60 \\
\hline 223 & 120 & -270 & 80 & 39 & 60 \\
\hline 224 & 121 & -280 & 80 & 39 & 60 \\
\hline 225 & 122 & -290 & 80 & 39 & 60 \\
\hline 226 & 123 & -300 & 80 & 39 & 60 \\
\hline 227 & 124 & -310 & 81 & 39 & 59 \\
\hline 228 & 125 & -320 & 80 & 39 & 60 \\
\hline 229 & 126 & -330 & 80 & 39 & 60 \\
\hline 230 & 127 & -340 & 80 & 39 & 60 \\
\hline 231 & 128 & -350 & 80 & 39 & 60 \\
\hline 231 & 129 & -360 & 80 & 39 & 60 \\
\hline 233 & 130 & -370 & 80 & 39 & 60 \\
\hline 234 & 133 & -380 & 80 & 39 & 60 \\
\hline 235 & 132 & -390 & 79 & 39 & 60 \\
\hline $2 \overline{36}$ & 133 & -400 & 79 & 39 & 60 \\
\hline 237 & 134 & -410 & 79 & 39 & 60 \\
\hline 238 & 135 & -420 & 78 & 39 & 60 \\
\hline 239 & 136 & -430 & 78 & 39 & 60 \\
\hline 240 & 137 & -440 & 78 & 39 & 59 \\
\hline 241 & 138 & -450 & 78 & 40 & 59 \\
\hline 242 & 139 & -460 & 78 & 40 & 59 \\
\hline 243 & 140 & -470 & 78 & 39 & 60 \\
\hline 244 & 141 & -480 & 77 & 39 & 60 \\
\hline 245 & 142 & -490 & 78 & 39 & 60 \\
\hline
\end{tabular}


Trajectory Parameters of 3-in. Dia. Steel Pipe in F5 Tornado (cont.)

\begin{tabular}{|c|c|c|c|c|c|}
\hline $\begin{array}{l}\text { Missile } \\
\text { Spaced } \\
\text { Number }\end{array}$ & $\begin{array}{l}\text { Missile } \\
\text { Trajectory } \\
\text { Number }\end{array}$ & $\begin{array}{l}\text { Distance to } \\
\text { Tornado } \\
\text { Path (ft) }\end{array}$ & $\begin{array}{l}\text { Maximum } \\
\text { Horizontal } \\
\text { Speed (mph) }\end{array}$ & $\begin{array}{l}\text { Maximum } \\
\text { Vertical } \\
\text { Speed (mph) }\end{array}$ & $\begin{array}{l}\text { Maximum } \\
\text { Height } \\
\text { (ft) }\end{array}$ \\
\hline 246 & 143 & -500 & 78 & 40 & 60 \\
\hline 247 & 144 & -510 & 78 & 40 & 60 \\
\hline 248 & 145 & -520 & 77 & 40 & 59 \\
\hline 249 & 146 & -530 & 78 & 39 & 60 \\
\hline 250 & 147 & -540 & 78 & 39 & 60 \\
\hline 251 & 148 & -550 & 77 & 40 & 60 \\
\hline 252 & 149 & -560 & 77 & 40 & 59 \\
\hline 253 & 150 & -570 & 76 & 39 & 59 \\
\hline 254 & 151 & -580 & 78 & 40 & 60 \\
\hline 255 & 152 & -590 & 77 & 40 & 59 \\
\hline 256 & 153 & -600 & 76 & 40 & $5 \overline{9}$ \\
\hline 257 & 154 & -610 & 76 & 40 & 59 \\
\hline 258 & 155 & -620 & 77 & 40 & 60 \\
\hline 259 & 156 & -630 & 76 & 39 & 59 \\
\hline 260 & 157 & -640 & 75 & 40 & 59 \\
\hline 261 & 158 & -650 & 76 & 40 & 60 \\
\hline 262 & 159 & -660 & 76 & 40 & 59 \\
\hline 263 & 160 & -670 & 76 & 40 & 59 \\
\hline 264 & 161 & -680 & 75 & 39 & 59 \\
\hline 265 & 162 & -690 & 75 & 40 & 59 \\
\hline 266 & 163 & -700 & 75 & 40 & 59 \\
\hline 267 & 164 & -710 & 76 & 40 & 59 \\
\hline 268 & 165 & -720 & 76 & 40 & 59 \\
\hline 269 & 166 & -730 & 75 & 40 & 60 \\
\hline 270 & 167 & -740 & 75 & 39 & 59 \\
\hline 271 & 168 & -750 & 74 & 40 & 59 \\
\hline 272 & 169 & -760 & 75 & 40 & 59 \\
\hline 273 & 170 & -770 & 74 & 39 & 59 \\
\hline 274 & 171 & -780 & 75 & 40 & 60 \\
\hline 275 & 172 & -790 & 74 & 40 & 59 \\
\hline 276 & 173 & -810 & 74 & 40 & 59 \\
\hline 277 & 174 & -820 & 74 & 40 & 59 \\
\hline 278 & 175 & -830 & 74 & 40 & 58 \\
\hline 279 & 176 & -830 & 75 & 39 & 59 \\
\hline 280 & 177 & -840 & 74 & 40 & 59 \\
\hline
\end{tabular}


Trajcctory Parameters of 3-in. Dia. Steel Pipe in F5 Tornado (cont.)

\begin{tabular}{|c|c|c|c|c|c|}
\hline $\begin{array}{l}\text { Missile } \\
\text { Spaced } \\
\text { Number }\end{array}$ & $\begin{array}{l}\text { Missile } \\
\text { Trajectory } \\
\text { Number }\end{array}$ & $\begin{array}{l}\text { Distance to } \\
\text { Tornado } \\
\text { Path (ft) }\end{array}$ & $\begin{array}{l}\text { Maximum } \\
\text { Horizontal } \\
\text { Speed (mph) }\end{array}$ & $\begin{array}{l}\text { Maximum } \\
\text { Vertical } \\
\text { Speed (mph) }\end{array}$ & $\begin{array}{l}\text { Maximum } \\
\text { Height } \\
\text { (ft) }\end{array}$ \\
\hline 246 & 143 & -500 & 78 & 40 & 60 \\
\hline 247 & 144 & -510 & 78 & 40 & 60 \\
\hline 248 & 145 & -520 & 77 & 40 & 59 \\
\hline 249 & 146 & -530 & 78 & 39 & 60 \\
\hline 250 & 147 & -540 & 78 & 39 & 60 \\
\hline 251 & 148 & -550 & 77 & 40 & 60 \\
\hline 252 & 149 & -560 & 77 & 40 & 59 \\
\hline 253 & 150 & -570 & 76 & 39 & 59 \\
\hline 254 & 151 & -580 & 78 & 40 & 60 \\
\hline 255 & 152 & -590 & 77 & 40 & 59 \\
\hline 256 & 153 & -600 & 76 & 40 & 59 \\
\hline 257 & 154 & -610 & 76 & 40 & 59 \\
\hline 258 & 155 & -620 & 77 & 40 & 60 \\
\hline 259 & 156 & -630 & 76 & 39 & 59 \\
\hline 260 & 157 & -640 & 75 & 40 & 59 \\
\hline 261 & 158 & -650 & 76 & 40 & 60 \\
\hline 262 & 159 & -660 & 76 & 40 & 59 \\
\hline 263 & 160 & -670 & 76 & 40 & 59 \\
\hline 264 & 161 & -680 & 75 & 39 & 59 \\
\hline 265 & 162 & -690 & $\overline{75}$ & 40 & 59 \\
\hline 266 & 163 & -700 & 75 & 40 & 59 \\
\hline 267 & 164 & -710 & 76 & 40 & 59 \\
\hline 268 & 165 & -720 & 76 & 40 & 59 \\
\hline 269 & 166 & -730 & 75 & 40 & 60 \\
\hline 270 & 167 & -740 & 75 & 39 & 59 \\
\hline 271 & 168 & -750 & 74 & 40 & 59 \\
\hline 272 & 169 & -760 & 75 & 40 & 59 \\
\hline 273 & 170 & -770 & 74 & 39 & 59 \\
\hline 274 & 171 & -780 & 75 & 40 & 60 \\
\hline 275 & 172 & -790 & 74 & 40 & 59 \\
\hline 276 & 173 & -810 & 74 & 40 & 59 \\
\hline 277 & 174 & -820 & 74 & 40 & 59 \\
\hline 278 & 175 & -830 & 74 & 40 & 58 \\
\hline 279 & 176 & -830 & 75 & 39 & 59 \\
\hline 280 & 177 & -840 & 74 & 40 & 59 \\
\hline
\end{tabular}


Trajectory Parametcrs of 3-in. Dia. Steel Pipe in F5 Tornado (cont.)

\begin{tabular}{|c|c|c|c|c|c|}
\hline $\begin{array}{l}\text { Missile } \\
\text { Spaced } \\
\text { Number } \\
\end{array}$ & $\begin{array}{l}\text { Missile } \\
\text { Trajectory } \\
\text { Number }\end{array}$ & $\begin{array}{l}\text { Distance to } \\
\text { Tornado } \\
\text { Path (ft) }\end{array}$ & $\begin{array}{l}\text { Maximum } \\
\text { Horizontal } \\
\text { Speed (mph) }\end{array}$ & $\begin{array}{l}\text { Maximum } \\
\text { Vertical } \\
\text { Speed (mph) }\end{array}$ & $\begin{array}{l}\text { Maximum } \\
\text { Height } \\
\text { (ft) }\end{array}$ \\
\hline 281 & 178 & -850 & 73 & 38 & 59 \\
\hline 282 & 179 & -860 & 74 & 40 & 59 \\
\hline 283 & 180 & -870 & 74 & 40 & 58 \\
\hline 284 & 181 & -880 & 73 & 38 & 59 \\
\hline 285 & 182 & -890 & 74 & 40 & 59 \\
\hline 286 & 183 & -900 & 74 & 40 & 59 \\
\hline 287 & 184 & -910 & 74 & 38 & 58 \\
\hline 288 & 185 & -920 & 73 & 40 & 59 \\
\hline 289 & 186 & -930 & 73 & 40 & 59 \\
\hline 290 & 187 & -940 & 72 & 39 & 58 \\
\hline 291 & 188 & -950 & 72 & 38 & 59 \\
\hline 292 & 189 & -960 & 72 & 38 & 59 \\
\hline 293 & 190 & -970 & 72 & 39 & 58 \\
\hline 294 & 191 & -980 & 72 & 39 & 59 \\
\hline 295 & 192 & -99 & 72 & 39 & 59 \\
\hline 296 & 193 & -1000 & 72 & 39 & 59 \\
\hline 297 & 104 & -1110 & 72 & 39 & 59 \\
\hline 298 & 195 & -1020 & 71 & 39 & 59 \\
\hline 299 & 196 & -1030 & 72 & 38 & 59 \\
\hline 300 & 197 & -1040 & 72 & 39 & 58 \\
\hline 301 & 198 & -1050 & 72 & 39 & 59 \\
\hline 302 & 199 & -1060 & 72 & 39 & 59 \\
\hline 303 & 200 & -1070 & 72 & 39 & 59 \\
\hline 304 & 201 & -1080 & 72 & 39 & 58 \\
\hline 305 & 202 & -1090 & 71 & 39 & 59 \\
\hline 306 & 203 & -1100 & 72 & 38 & 59 \\
\hline 307 & 204 & -1110 & 72 & 39 & 59 \\
\hline 308 & 205 & -1120 & 71 & 39 & 58 \\
\hline 309 & 206 & -1130 & 71 & 39 & 59 \\
\hline 310 & 207 & -1140 & 71 & 39 & 59 \\
\hline 311 & 208 & -1150 & 71 & 38 & 59 \\
\hline 312 & 208 & -1160 & 71 & 39 & 59 \\
\hline 313 & 210 & -1170 & 70 & 39 & 59 \\
\hline 314 & 211 & -1180 & 70 & 39 & 58 \\
\hline 315 & 212 & -1190 & 70 & 39 & 58 \\
\hline
\end{tabular}


Trajectory Parameters of 3-in. Dia. Stcel Pipe in F5 Tornado (cont.)

\begin{tabular}{|c|c|c|c|c|c|}
\hline $\begin{array}{l}\text { Missile } \\
\text { Spaced } \\
\text { Number }\end{array}$ & $\begin{array}{l}\text { Missile } \\
\text { Trajectory } \\
\text { Number }\end{array}$ & $\begin{array}{l}\text { Distance to } \\
\text { Tornado } \\
\text { Path (ft) }\end{array}$ & $\begin{array}{l}\text { Maximum } \\
\text { Horizontal } \\
\text { Speed (mph) }\end{array}$ & $\begin{array}{l}\text { Maximum } \\
\text { Vertical } \\
\text { Speed (mph) }\end{array}$ & $\begin{array}{l}\text { Maximum } \\
\text { I Ieight } \\
\text { (ft) }\end{array}$ \\
\hline 316 & 213 & -1200 & 70 & 39 & 58 \\
\hline 317 & 214 & -1210 & 70 & 39 & 59 \\
\hline 318 & 215 & -1220 & 70 & 39 & 58 \\
\hline 319 & 216 & -1230 & 70 & 39 & 58 \\
\hline 320 & 217 & -1240 & 69 & 39 & 58 \\
\hline 321 & 218 & -1250 & 70 & 39 & 58 \\
\hline 322 & 219 & -1260 & 70 & 39 & 58 \\
\hline 323 & 220 & -1270 & 70 & 38 & 58 \\
\hline 324 & 221 & -1280 & 70 & 39 & 58 \\
\hline 325 & 222 & -1290 & 69 & 39 & 58 \\
\hline 326 & 223 & -1300 & 70 & 39 & 58 \\
\hline 327 & 224 & -1310 & 69 & 39 & 58 \\
\hline 328 & 225 & -1320 & 69 & 39 & 58 \\
\hline 339 & 226 & -1330 & 69 & 39 & 57 \\
\hline 330 & 227 & -1340 & 69 & 38 & 58 \\
\hline 331 & 228 & -1350 & 69 & 39 & 58 \\
\hline 332 & 229 & -1360 & 69 & 39 & 58 \\
\hline 333 & 230 & -1370 & 68 & 39 & 58 \\
\hline 334 & 231 & -1380 & 68 & 38 & 57 \\
\hline 335 & 232 & -1390 & 68 & 39 & 58 \\
\hline 336 & 233 & -1400 & 68 & 39 & 58 \\
\hline 337 & 234 & -1410 & 68 & 39 & 58 \\
\hline 338 & 235 & -1420 & 68 & 39 & 58 \\
\hline 339 & 236 & -1430 & 68 & 39 & 58 \\
\hline 340 & 237 & -1440 & 68 & 38 & 58 \\
\hline 341 & 238 & -1450 & 68 & 39 & 58 \\
\hline 342 & 239 & -1460 & 68 & 38 & 58 \\
\hline 343 & 240 & -1470 & 67 & 39 & 58 \\
\hline \multicolumn{6}{|l|}{344} \\
\hline 345 & 242 & -1490 & 67 & 39 & 57 \\
\hline 346 & 243 & -1500 & 68 & 39 & 58 \\
\hline 347 & 244 & -1510 & 68 & 39 & 58 \\
\hline \multicolumn{6}{|l|}{348} \\
\hline 349 & & & & & \\
\hline 350 & 247 & -1540 & 67 & 39 & 57 \\
\hline
\end{tabular}


Trajectory Parameters of 3-in. Dia. Steel Pipe in F5 Tornado (cont.)

\begin{tabular}{|c|c|c|c|c|c|}
\hline $\begin{array}{l}\text { Missile } \\
\text { Spaced } \\
\text { Number }\end{array}$ & $\begin{array}{l}\text { Missile } \\
\text { Trajectory } \\
\text { Number }\end{array}$ & $\begin{array}{l}\text { Distance to } \\
\text { Tornado } \\
\text { Path (ft) }\end{array}$ & $\begin{array}{l}\text { Maximum } \\
\text { Horizontal } \\
\text { Speed (mph) }\end{array}$ & $\begin{array}{l}\text { Maximum } \\
\text { Vertical } \\
\text { Speed (mph) }\end{array}$ & $\begin{array}{l}\text { Maximum } \\
\text { Height } \\
\text { (ft) }\end{array}$ \\
\hline 351 & 248 & -1550 & 67 & 39 & 58 \\
\hline 352 & 249 & -1560 & 67 & 40 & 58 \\
\hline 353 & 250 & -1570 & 66 & 40 & 58 \\
\hline 354 & 251 & -1580 & 66 & 40 & 58 \\
\hline 455 & 252 & -1590 & 66 & 40 & 58 \\
\hline 356 & 253 & -1600 & 66 & 40 & 58 \\
\hline 357 & 254 & -1610 & 65 & 40 & 58 \\
\hline 358 & 255 & -1620 & 65 & 39 & 57 \\
\hline 358 & 256 & -1630 & 65 & 39 & 57 \\
\hline 360 & & -1640 & & & \\
\hline 361 & & -1650 & & & \\
\hline 362 & & -1660 & & & \\
\hline 363 & & -1670 & & & \\
\hline 364 & & -1680 & & & \\
\hline 365 & & -1690 & & & \\
\hline 366 & & -1700 & & & \\
\hline 367 & & -1710 & & & \\
\hline 368 & & -1720 & & & \\
\hline 369 & & -1730 & & & \\
\hline 370 & & -1740 & & & \\
\hline 371 & & -1750 & & & \\
\hline 372 & & -1760 & & & \\
\hline 373 & & -1770 & & & \\
\hline 374 & & -1780 & & & \\
\hline 375 & & -1790 & & & \\
\hline 376 & & -1800 & & & \\
\hline 377 & & -1810 & & & \\
\hline 378 & & -1820 & & & \\
\hline 379 & & -1830 & & & \\
\hline 380 & & -1840 & & & \\
\hline 381 & & -1850 & & & \\
\hline 382 & & -1860 & & & \\
\hline 383 & & 1870 & & & \\
\hline 384 & & -1880 & & & \\
\hline 385 & & -1890 & & & \\
\hline
\end{tabular}


Trajectory Parameters of 3-in. Dia. Steel Pipe in F5 Tornado (cont.)

\begin{tabular}{|c|c|c|c|c|c|}
\hline $\begin{array}{l}\text { Missile } \\
\text { Spaced } \\
\text { Number }\end{array}$ & $\begin{array}{l}\text { Missile } \\
\text { Trajectory } \\
\text { Number }\end{array}$ & $\begin{array}{l}\text { Distance to } \\
\text { Tornado } \\
\text { Path (ft) }\end{array}$ & $\begin{array}{l}\text { Maximum } \\
\text { Horizontal } \\
\text { Speed (mph) }\end{array}$ & $\begin{array}{l}\text { Maximum } \\
\text { Vertical } \\
\text { Speed (mph) }\end{array}$ & $\begin{array}{l}\text { Maximum } \\
\text { Height } \\
\text { (ft) }\end{array}$ \\
\hline 386 & & -1900 & & No & Release \\
\hline 387 & & -1910 & & . & . \\
\hline 388 & & -1920 & & . & . \\
\hline 389 & & -1930 & & . & . \\
\hline 390 & & -1940 & & . & . \\
\hline 391 & & -1950 & & . & . \\
\hline 392 & & -1960 & & . & . \\
\hline 393 & & -1970 & & . & . \\
\hline 394 & & -1980 & & . & . \\
\hline 395 & & -1990 & & . & . \\
\hline 396 & & -2000 & & . & . \\
\hline 397 & & -2010 & & . & . \\
\hline 398 & & -2020 & & . & . \\
\hline 399 & & -2030 & & . & . \\
\hline 400 & & -2040 & & . & . \\
\hline 401 & & -2050 & & . & . \\
\hline 402 & & -2060 & & . & . \\
\hline 403 & & -2070 & & . & . \\
\hline 404 & & -2080 & & . & . \\
\hline 405 & & -2090 & & . & . \\
\hline 406 & & -2100 & & . & . \\
\hline 407 & & -2110 & & . & . \\
\hline 408 & & -2120 & & . & . \\
\hline 409 & & -2130 & & . & . \\
\hline 410 & & -2140 & & . & . \\
\hline 411 & & -2150 & & . & . \\
\hline 412 & & -2160 & & . & . \\
\hline 413 & & -2170 & & . & . \\
\hline 414 & & -2180 & & . & . \\
\hline 415 & & -2190 & & . & . \\
\hline 416 & & -2200 & & . & . \\
\hline 417 & & -2210 & & . & . \\
\hline 418 & & -2220 & & . & . \\
\hline 419 & & -2230 & & . & . \\
\hline 420 & & -2240 & & . & \\
\hline
\end{tabular}


Trajectory Parameters of 3-in. Dia. Steel Pipe in F5 Tornado (cont.)

\begin{tabular}{|c|c|c|c|c|c|}
\hline $\begin{array}{l}\text { Missile } \\
\text { Spaced } \\
\text { Number }\end{array}$ & $\begin{array}{l}\text { Missile } \\
\text { Trajectory } \\
\text { Number }\end{array}$ & $\begin{array}{l}\text { Distance to } \\
\text { Tornado } \\
\text { Path (ft) }\end{array}$ & $\begin{array}{l}\text { Maximum } \\
\text { Horizontal } \\
\text { Speed (mph) }\end{array}$ & $\begin{array}{l}\text { Maximum } \\
\text { Vertical } \\
\text { Speed (mph) }\end{array}$ & $\begin{array}{l}\text { Maximum } \\
\text { Height } \\
\text { (ft) }\end{array}$ \\
\hline 421 & & -2250 & & No & Release \\
\hline 422 & & -2260 & & . &. \\
\hline 423 & & -2270 & & . & . \\
\hline 424 & & -2280 & & . & . \\
\hline 425 & & -2290 & & . & . \\
\hline 426 & & -2300 & & . & . \\
\hline 427 & & -2310 & & . & . \\
\hline 428 & & -2320 & & . & . \\
\hline 429 & & -2330 & & . & . \\
\hline 430 & & -2340 & & . &. \\
\hline 431 & & -2350 & & . & . \\
\hline 432 & & -2360 & & . & . \\
\hline 433 & & -2370 & & . & . \\
\hline 434 & & -2380 & & . & . \\
\hline 435 & & -2390 & & . & . \\
\hline 436 & & -2400 & & . & . \\
\hline 437 & & -2410 & &. & . \\
\hline 438 & & -2420 & & . & . \\
\hline 439 & & -2430 & &. & . \\
\hline 440 & & -2440 & & $\cdot$ & . \\
\hline 441 & & -2450 & & . & . \\
\hline 442 & & -2460 & & . & . \\
\hline 443 & & -2470 & & . & . \\
\hline 444 & & -2480 & & . & . \\
\hline 445 & & -2490 & & - & . \\
\hline 446 & & -2500 & & . & . \\
\hline 447 & & -2510 & & . & . \\
\hline 448 & & -2520 & & . & . \\
\hline 449 & & -2530 & & . & . \\
\hline 450 & & -2540 & & . & . \\
\hline 451 & & -2550 & & . & . \\
\hline 452 & & -2560 & & . & . \\
\hline 453 & & -2570 & & . & . \\
\hline 454 & & -2580 & & . & . \\
\hline 455 & & -2590 & & & . \\
\hline
\end{tabular}


Trajectory Parameters of 3-in. Dia. Steel, Pipe in F5 Tornado (cont.)

\begin{tabular}{|c|c|c|c|c|c|}
\hline $\begin{array}{l}\text { Missile } \\
\text { Spaced } \\
\text { Number }\end{array}$ & $\begin{array}{l}\text { Missile } \\
\text { Trajectory } \\
\text { Number }\end{array}$ & $\begin{array}{l}\text { Distance to } \\
\text { Tornado } \\
\text { Path (ft) }\end{array}$ & $\begin{array}{l}\text { Maximum } \\
\text { Horizontal } \\
\text { Speed (mph) }\end{array}$ & $\begin{array}{l}\text { Maximum } \\
\text { Vertical } \\
\text { Speed (mph) }\end{array}$ & $\begin{array}{l}\text { Maximum } \\
\text { Height } \\
\text { (ft) }\end{array}$ \\
\hline 456 & & -2600 & & No & Release \\
\hline 457 & & -2610 & & . & . \\
\hline 458 & & -2620 & & . & . \\
\hline 459 & & -2630 & & . & . \\
\hline 460 & & -2640 & & . & . \\
\hline 461 & & -2650 & & . & . \\
\hline 462 & & -2660 & & . & . \\
\hline 463 & & -2670 & & . & . \\
\hline
\end{tabular}




\section{.}




\section{APPENDIX D \\ DBT-77 TORNADO WINDFIELD MODEL}

A schematic diagram of the single vortex windfield model, DBT-77, is shown in Figure D-1. The model is an axis-symmetrical vortex with a cylindrical core. The core is divided into two parts: an inner core with radius $R_{n}$, and an outer core with radius $R_{0}$. Vertical motions are confined to the outer core. The inner core contains a region of rotational flow surrounded by the outer core, which contains irrotational flow. The inflow layer has a height $\mathrm{H}_{\mathrm{i}}$, where air feed into the outer core of the tornado and then flows vertically upward. Above the inflow layer, the flow is outward.

The tangential velocity component in this model is expressed as the product or two functions, each of which varies with height and radius. The tangential velocity is given by

$$
\mathrm{V}=\mathrm{F}(\mathrm{r}) \mathrm{F}(\mathrm{h}) \mathrm{V}_{\mathrm{m}}
$$

where $V_{m}$ is the maximum tangential wind speed; $F(r)$ and $F(h)$ are identified as radial and height function, respectively. They are given by

D-2

$$
\begin{aligned}
& F(r)=r \quad(r<1), \text { or } F(r)=1 / r \quad(r>1) \\
& F(h)=h^{k}(h<1), \text { or } F(h)=e^{-k(h-1)}(h>1)
\end{aligned}
$$

where $\mathrm{r}$ and $\mathrm{h}$ are the normalized radius and the normalized height, respectively, at which the tangential wind speed is calculated. Values of $k_{0}$ and $k$ are assumed to be $1 / 6$ and 0.03 in this model.

The radial wind speed is expressed in this model by

$$
\mathrm{U}=\mathrm{V} \tan \alpha
$$

where $\alpha$ is the crossing angle, which denotes the angle between the direction of the incoming air flow and a concentric circle of radius $r$ at their crossover point. In this model, $\alpha$ is assumed to be zero inside the inner core. It increases or decreases out ward within the outer core, reaching $\alpha_{\circ}$ at its outer edge. Outside the core, $\alpha_{0}$ is expressed by

$$
\tan \alpha_{\mathrm{o}}=-\mathrm{A}_{\mathrm{m}}\left(1-\mathrm{h}^{3 / 2}\right) \quad \text { inside inflow layer }
$$


$\tan \alpha_{0} B_{m}\left(1-e^{-k(h-1)}\right) \quad$ outside inflow layer

where $A_{m}$ and $B_{m}$ are positive nondimensional quantities called the "maximum inflow tangent" and the "maximum outer tangent," respectively. Values of $A_{m}$ and $B_{m}$ are assumed to be 0.75 and 0.0217 in this model.

The vertical velocity component inside the inner core and outside the outer core is assumed to be zero. Inside the outer core, the vertical velocity is expressed by D-4

$$
\mathrm{W}=\mathrm{W}_{\mathrm{o}} \mathrm{V}_{\mathrm{m}}
$$

where

$$
\begin{array}{ll}
\mathrm{w}_{\mathrm{o}}=0.0442\left(16 \mathrm{~h}^{7 / 6}-7 \mathrm{~h}^{8 / 3}\right) & \text { at inflow height } \\
\mathrm{w}_{\mathrm{o}}=0.398\left[2 \mathrm{e}^{-\mathrm{k}(\mathrm{h}-1)}-\mathrm{e}^{-2 \mathrm{k}(\mathrm{h}-1)}\right] & \text { at outflow height. }
\end{array}
$$




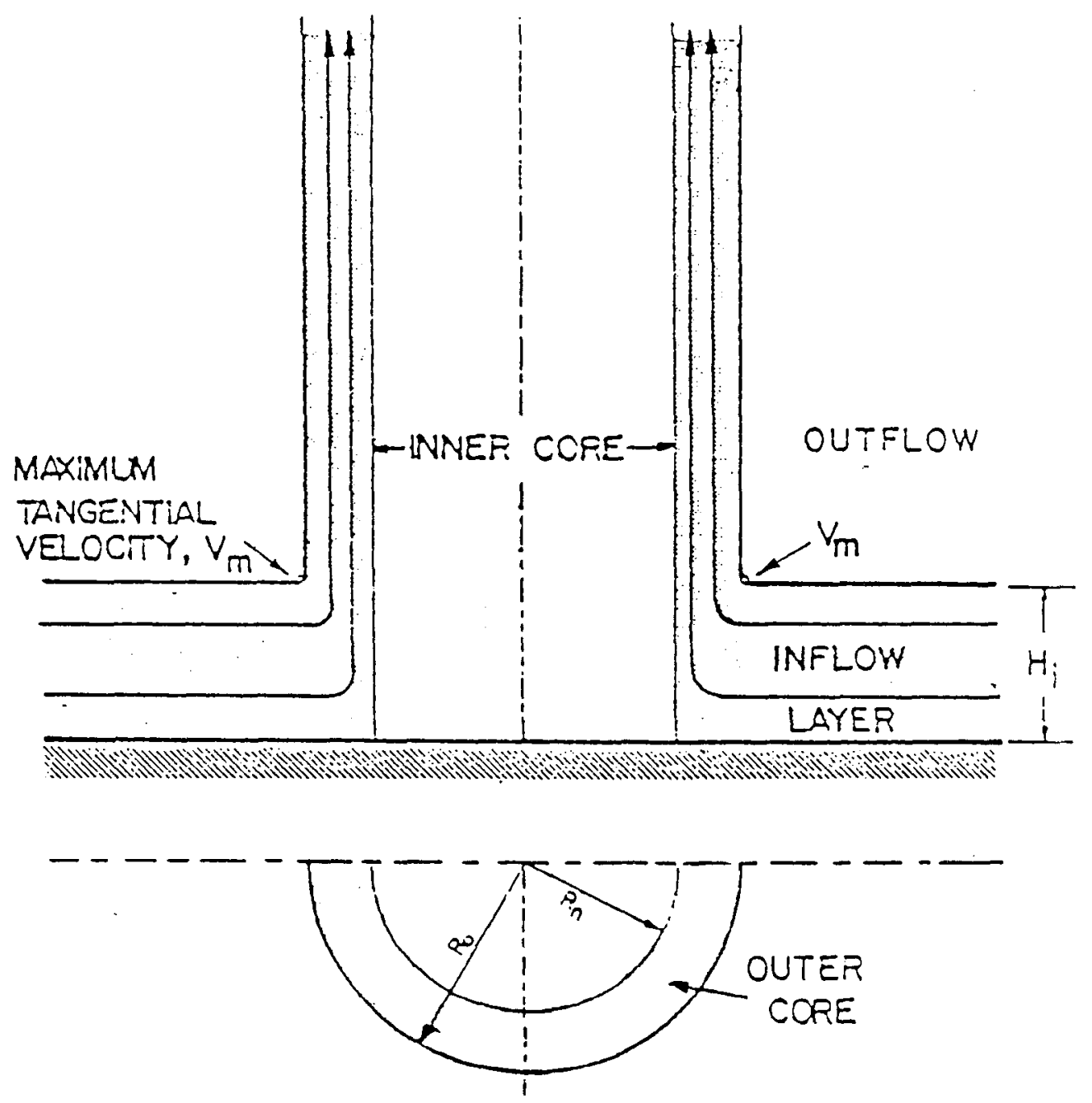

FIGURE D-1 FUJITA DBT-77 WIND FIELD MODEL

D-3 



\section{APENDIX E \\ PRESSURE VS. VELOCITY CALCULATIONS}

The pressure vs. velocity calculations are reproduced from Bailey's (1984) thesis.

Figure $\mathrm{Ej}-1$ shows the plot of the theoretical curve produced by these calculations. Also show is the pressure vs. velocity curve produced from actual testing.

By Newton's Second Law:

\section{CALCULATIONS}

$$
\mathrm{F}=\mathrm{ma}
$$

Assuming constant, rectilinear acceleration

over the length of the

barrel:

$$
\mathrm{v}^{2}=2 \mathrm{a}\left(\mathrm{x}-\mathrm{x}_{\mathrm{o}}\right)+\mathrm{v}_{\mathrm{o}}^{2}
$$

Rearranging, noting

$$
\mathrm{x}_{\mathrm{o}}=\mathrm{v}_{\mathrm{o}}=0 \text { : }
$$

$$
a=v^{2} /(2 x)
$$

Noting $\mathrm{x}=$ "length of

barrel," $L_{B}$ :

Since $\mathrm{P}_{\text {avg }}\left(\mathrm{A}_{\text {barrel }}\right)=\mathrm{F}_{\text {avg }}$ :

Substituting for a:

Noting volume, $V_{B}=A_{B} L_{B}$ :

By The Ideal Gas Law:

Assuming:

Substituting:

$$
\mathrm{a}=\mathrm{v}^{2} /\left(2 \mathrm{~L}_{\mathrm{B}}\right)
$$$$
\mathrm{P}_{\mathrm{avg}}\left(\mathrm{A}_{\mathrm{B}}\right)=\mathrm{ma}
$$$$
\mathrm{P}_{\mathrm{avg}}\left(\mathrm{A}_{\mathrm{B}}\right)=\mathrm{mv}^{2} /\left(2 \mathrm{~L}_{\mathrm{B}}\right)
$$$$
\mathrm{P}_{\mathrm{B}}=\mathrm{mv}^{2} /\left(2 \mathrm{~V}_{\mathrm{B}}\right)
$$$$
P_{f}=\frac{P_{i}\left(V_{\text {tan } k}\right)}{V_{\text {tan } k}+V_{\text {barrel }}}
$$

$$
P_{\text {avg }}=\frac{P_{f}+P_{i}}{2}
$$

$$
P_{\text {avg }}=\frac{P_{i}}{2}+\frac{P_{i} V_{T}}{2\left(V_{T}+V_{B}\right)}
$$

E-1 
Or:

$$
\mathrm{P}_{\mathrm{avg}}=\frac{\mathrm{P}_{\mathrm{i}}}{2}\left(1+\frac{\mathrm{V}_{\mathrm{T}}}{\mathrm{V}_{\mathrm{T}}+\mathrm{V}_{\mathrm{B}}}\right)
$$

Substituting:

$$
\frac{m v^{2}}{2 V_{B}}=\frac{P_{i}}{2}\left(1+\frac{V_{T}}{V_{T}+V_{B}}\right)
$$$$
\frac{m v^{2}}{V_{B}}=P_{i}\left(\frac{2 V_{T}+V_{B}}{V_{T}+V_{B}}\right)
$$

Thus:

$$
\mathrm{v}^{2}=\frac{\mathrm{P}_{\mathrm{i}}\left(\mathrm{V}_{\mathrm{B}}\right)}{\mathrm{m}}\left(\frac{2 \mathrm{~V}_{\mathrm{T}}+\mathrm{V}_{\mathrm{B}}}{\mathrm{V}_{\mathrm{T}}+\mathrm{V}_{\mathrm{B}}}\right)
$$

Let:

$$
\mathrm{k}=\mathrm{V}_{\mathrm{B}}\left(\frac{2 \mathrm{~V}_{\mathrm{T}}+\mathrm{V}_{\mathrm{B}}}{\mathrm{V}_{\mathrm{T}}+\mathrm{V}_{\mathrm{B}}}\right)\left(\mathrm{ft}^{3}\right)
$$

Therefore:

$$
\mathrm{v}^{2}=\frac{\mathrm{P}_{\mathrm{i}} \mathrm{k}}{\mathrm{m}}
$$

Or:

$$
v=\sqrt{\frac{P_{i} k}{m}}
$$

From calculations

Previously made:

$$
\mathrm{k}=3.239 \mathrm{ft}^{3}
$$

For readings made in psi, a unit conversion is required:

$$
\mathrm{P}_{\mathrm{i}}(\mathrm{psi}) \times 144 \mathrm{in}^{2} / \mathrm{ft}^{2}=\mathrm{P}_{\mathrm{i}}(\mathrm{psf})
$$

The mass of the missile is

found by dividing its

mass with gravity:

$$
\mathrm{m}=\frac{\mathrm{W}}{\mathrm{g}}=\frac{\mathrm{W}}{32.2}\left(\frac{\mathrm{lb} \mathrm{s}^{2}}{\mathrm{ft}}\right)
$$


After all substitutions and conversions:

$$
\mathrm{v}=\left[\frac{\mathrm{P}_{\mathrm{i}}}{\mathrm{W}}(32.2)(3.2239)(144)\right]^{1 / 2} \quad \text { Or }: \quad \mathrm{v}=122.55 \sqrt{\frac{\mathrm{P}_{\mathrm{i}}}{\mathrm{W}}}
$$

Where: $\quad \mathrm{P}=$ initial air pressure (psi)

$\mathrm{W}=$ weight of missile (lbs)

$\mathrm{v}=$ exit velocity of missile (fps)

(Note: To convert v(fps) to $\mathrm{v}(\mathrm{mph})$, multiply by 0.6818$)$. 

APPENDIX F

MATERIAL PROPERTIES

F-1 
The various materials used to construct the barriers are listed and described below. The properties of each material are given below. The properties of each material are given based on information provided by the supplier or from published sources.

\section{Concrete}

concrete with 400 psi target compressive strength @ 28 days ( 3 to 5 in. slump - 0.48 W/C ratio), cement-type I Portland ASTM C-150, Sand - RE Janes \#4 - 0, Gravel -RE Janes 1.0.in., Admix. Masterbuildres Pozz LL761 and MBVR; Proportions by volume are as follows:

$\begin{array}{ll}\text { Cement: } & 3.18 \mathrm{ft}^{3} \\ \text { Sand: } & 7.07 \mathrm{ft}^{3} \\ \text { Gravel: } & 10.60 \mathrm{ft}^{3} \\ \text { Water } & 4.80 \mathrm{ft}^{3} \\ \text { Pozz LL61: } \quad \text { (neg.- 180z.) } & \\ \text { MBVR:1,35 } \mathrm{ft}^{3}\end{array}$

Average compressive strength found from 6 in. diameter, 12 in. tall test cylinder samples was 4759 psi; average split tensile stress, which was found from 3 test cylinders, was 321 psi.

\section{$\underline{\text { Steel Rebar }}$}

$\# 3$ (0.375 in.) and \#4 (0.50 in.) diameter rebar; 40,000 psi steel; 42 in. and 52 in. lengths were cut from a $20 \mathrm{ft}$. length.

\section{Concrete Masonry Units}

8 in. and 12 in. thick standard and half blocks, average compressive strength of 3911 psi found from two test prisms (two CMU blocks filled with grout); prisms cured 60 days. 
Grout

one part of Portland cement Type I (with high early strength (7 days) admixture), 3 parts sand, 2 parts pea gravel; three test samples of grout having the dimensions 3 in. $x 3$ in.x 6 in. were taken; after 60 days, samples possessed an average compressive strength of 4072 psi.

Mortar

S type, $1 / 2$ part Portland Cement Type III, 4 parts sand, concave mortar joints; three test samples of mortar having dimensions 3 in. $x 3$ in .x 6 in. were taken; average compressive strength of samples was 1456 psi; samples cured 60 days.

Brick

Standard clay brick, 2.25 in $\times 3.625$ in. $\times 7.75$ in.; two test prisms consisting of 3 bricks/prism had a compressive strength (flatwise) of 4720 psi.

3 in. Diameter Steel Pipe

Schedule 40 steel pipe, ranging from 117 in. - 122 in. length, weighing $7.5 \mathrm{lbs}$. Per ft ., 3.5 in. outside diameter, 3.07 in. inside diameter, 0.216 in wall thickness, 
. 
CIVIL EAGINEERINKS TEBTING LABORATORY

Department of Civil Engineering

Texas Tech University

Lubbock, Texas 79409

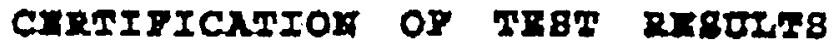

\section{Cl1ont, Lawrence Livermore National Laboratory}

Date: January 5, 1993

State of Texas

county of Lubbodk

James R. McDonald, P.E., being hly sworn, deposes and says that he 18 employed by Texas Teah University; that tornado misaile Impact tests of concrete and masonry wall epecimens were made under his supervision; that, to the best of his knowledge and belief, such tests were made in accordance with the particulars relating to such tests set forth in the specifications, and meet all requirements of the specifications. The results of such tests are shown in the Masters Thesls authored by Blail Nevins dated January 1993.

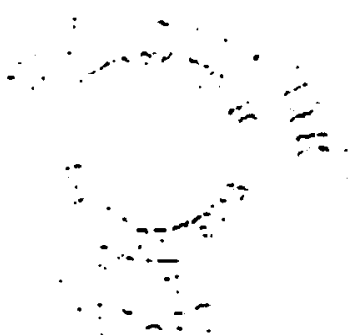

SIGNED:

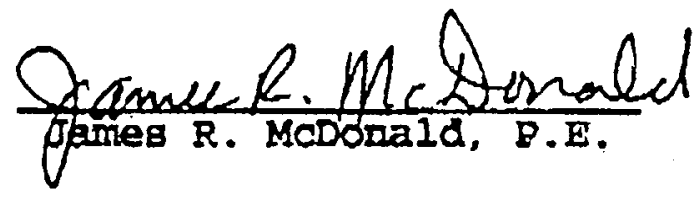

SUBSCRIBED AND 1993.

Ny Comission Expires:

$1-25 \cdot 93$

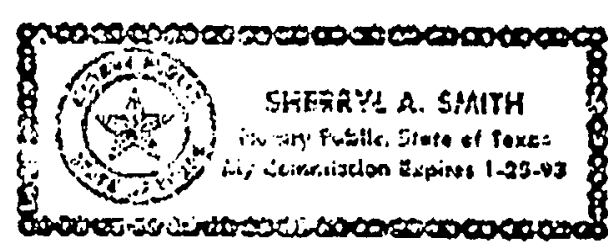

$\frac{\text { Sherrye } A \text {. Jonith }}{\text { Notary piblic of Texas }}$



APPENDIX G

DATA SHEETS

G-1 


\section{DATASHEET \\ TEST CR-6.1 \\ REINFORCED CONCRETE WALL \\ $12 / 10 / 90$}

Wall section:

Size:

39 in. $x 39$ in. concrete slab; 6

in. thick

Reinforcement: \#3's@9 in. o.c. each way placed

$1.5 \mathrm{in}$. from front face

Edge Support: $\quad$ Simply supported on all four sides

Age:

60 days

Strength:

Average compressive - 4759 psi;

Impact Point:

Average split tensile - 321 psi

Comments:

Center of slab

Impact point located between reinforcing bars

Missile:

Material:

Schedule 40 steel pipe

Size:

3 in. nominal diameter; 3.5 in.

Weight: 73.0 lbs. outside diameter; 119.5 in. long

End Shape:

Comments:

Blunt

after impact the pipe was 119.2 in.

length, 3.88 in. $x 3.38$ in oval

end shape

Launch Data:

Pressure:

Missile Velocity

$25 \mathrm{psi}$

Comments:

Impact Data:

Angle of Impact: $\quad 90^{\circ}$ - normal

Penetration:

0.375 in. deep x 5.0 in. diameter

Perforation:

No

Back Face Scabbing: No

Description of Response:

Vertical crack on front face and radical cracks on back face- crack propagation through slab. Maximum width of back face cracks was $3 / 16$ in.

Documentation:

High Speed Movies: No

VHS Video:

Front side - CR- 6.1

Still Photos:

CR- 6.1- 01 and CR - 6.1- 02 


\section{DATASHEET \\ TEST CR-6.2 \\ REINFORCED CONCRETE ROOF \\ $12 / 12 / 90$}

Wall section:

Size: $\quad 39$ in. $\times 39$ in. concrete slab; 6

in. thick

Reinforcement: \#4's@12 in. o.c. each way placed

1.5 in. from front face

Edge Support: $\quad$ Simply supported on all four sides

Age:

62 days

Strength:

Average compressive - 4759 psi;

Impact Point: $\quad$ Center of slab

Comments: $\quad$ Impact point located between reinforcing bars

Missile:

Material: $\quad$ Schedule 40 steel pipe

Size: $\quad 3$ in. nominal diameter; 3.5 in.

outside diameter; $118.5 \mathrm{in}$. long

Weight: $\quad 73.25$ lbs.

End Shape: Blunt

Comments: after impact the pipe was $118.4 \mathrm{in}$.

length, 3.5 in. $x 3.63$ in oval

end shape

Launch Data:

Pressure: $\quad 25 \mathrm{psi}$

Missile Velocity $\quad 37 \mathrm{mph}$

Comments:

Impact Data:

Angle of Impact: $\quad 90^{\circ}$-normal

Penetration: $\quad 0.375$ in. deep; cavity oval shape

Perforation: No

Back Face Scabbing: No

Description of Response:

Vertical crack on front face and radical cracks on back face- crack propagation through slab. Back face cracks had a maximum width of $1 / 16$ in.

Documentation:

High Speed Movies: No

VHS Video:

Front side - CR- 6.2

Still Photos:

CR- 6.2- 01 and CR - 6.2-02 


\section{DATA SHEET \\ TEST CR-6.3 \\ REINFORCED CONCRETE ROOF \\ $12 / 15 / 90$}

Wall section:

Size:

39 in. $x 39$ in. concrete slab; 6

in. thick

Reinforcement: \#3's@12 in. o.c. each way placed

1.5 in. from front face

Edge Support: $\quad$ Simply supported on all four sides

Age:

65 days

Strength:

Average compressive - 4759 psi;

Impact Point:

Average split tensile - 321 psi

Comments:

Center of slab

Impact point located between reinforcing bars

Missile:

Material: $\quad$ Schedule 40 steel pipe

Size: $\quad 3$ in. nominal diameter; 3.5 in.

Weight: $\quad 73.0 \mathrm{lbs}$.

End Shape: Blunt

Comments: after impact the pipe was 117.9 in.

length, 3.5 in. $x 3.63$ in oval

end shape

Launch Data:

Pressure: $\quad 25 \mathrm{psi}$

Missile Velocity $\quad 38 \mathrm{mph}$

Comments:

Impact Data:

Angle of Impact: $\quad 90^{\circ}$ - normal

Penetration: $\quad 0.375$ in. deep; cavity oval shape

Perforation: No

Back Face Scabbing: No

Description of Response:

Vertical crack on front face and radical cracks on back face- crack propagation through slab. Maximum width of back face cracks was $1 / 16$ in.

Documentation:

High Speed Movies: No

VHS Video: $\quad$ Front side - CR- 6.3

Still Photos: $\quad$ CR- 6.3-01 and CR $-6.3-02$ 


\section{DATASHEET \\ TEST CR-8.1 \\ REINFORCED CONCRETE SLAB \\ $12 / 18 / 90$}

Wall section:

Size: $\quad 39$ in. $\times 39$ in. concrete slab; 8

in. thick

Reinforcement: \#4's @ 9 in. o.c. each way placed

in middle of slab

Edge Support: $\quad$ Simply supported on all four sides

Age:

68 days

Strength:

Average compressive - 4759 psi;

Impact Point:

Average split tensile - 321 psi

Comments:

Center of slab

Impact point located between reinforcing bars

Missile:

Material:

Schedule 40 steel pipe

Size:

3 in. nominal diameter; 3.5 in.

Weight: $72.5 \mathrm{lbs}$. outside diameter; 117.5 in. long

End Shape:

Blunt

Comments:

after impact the pipe was 117.25 in.

length, 3.5 in. $x 3.75$ in oval

end shape

Launch Data:

Pressure:

Missile Velocity

Comments:

$30 \mathrm{psi}$

$44 \mathrm{mph}$

Impact Data:

Angle of Impact: $\quad 90^{\circ}$ - normal

Penetration: $\quad 0.375$ in. $x 5$ in. diameter

Perforation: No

Back Face Scabbing: No

Description of Response:

One horizontal crack on front face. Radical cracking on the back face.

Maximum width of back face cracks was $1 / 16$ in.

Documentation:

High Speed Movies: No

VHS Video:

Front side - CR- 8.1

Still Photos:

CR- 8.1- 01 and CR - 8.1- 02 


\section{DATA SHEET \\ TEST CR-8.2 \\ REINFORCED CONCRETE SLAB}

$12 / 20 / 90$

Wall section:

Size: $\quad 39$ in. $x 39$ in. concrete slab; 8

in. thick

Reinforcement: \#4's@12 in. o.c. each way placed

in middle of slab

Edge Support: $\quad$ Simply supported on all four sides

Age: 70 days

Strength:

Average compressive - $4759 \mathrm{psi}$;

Impact Point:

Average split tensile - 321 psi

Comments:

Center of slab

Impact point located between reinforcing bars

Missile:

Material: $\quad$ Schedule 40 steel pipe

Size: $\quad 3$ in. nominal diameter; 3.5 in.

outside diameter; 119.25 in. long

Weight: $\quad 79.5 \mathrm{lbs}$.

End Shape: Blunt

Comments: $\quad$ after impact the pipe was $119.10 \mathrm{in}$.

length, 3.5 in. $x 3.75$ in oval

end shape

Launch Data:

Pressure: $\quad 30 \mathrm{psi}$

Missile Velocity $\quad 44 \mathrm{mph}$

Comments:

Impact Data:

Angle of Impact: $\quad 90^{\circ}$ - normal

Penetration: $\quad 0.375$ in. deep cavity oval shape

Perforation: No

Back Face Scabbing: No

Description of Response:

One vertical crack on front face. Radical cracks on back face - crack propagation through

slab. Maximum width of back face cracks were hairline.

Documentation:

High Speed Movies: Fastax; front face through mirror -

CR -8.2

VHS Video: $\quad$ Front side - CR- 8.2

Still Photos: $\quad$ CR- 8.2- 01 and CR $-8.2-02$ 


\section{DATA SHEET \\ TEST CR - 8.3 \\ REINFORCED CONCRETE SLAB \\ $12 / 20 / 90$}

Wall section:

Size: $\quad 39$ in. $x 39$ in. concrete slab; 8

in. thick

Reinforcement: \#3's @ 12 in. o.c. each way each face, placed

1.5 in. away from each face

Edge Support: $\quad$ Simply supported on all four sides

Age:

70 days

Strength: $\quad$ Average compressive -4759 psi;

Average split tensile - 321 psi

Impact Point: $\quad$ Center of slab

Comments: Impact point located between reinforcing bars

Missile:

Material: $\quad$ Schedule 40 steel pipe

Size: $\quad 3$ in. nominal diameter; 3.5 in.

Weight: $\quad 79.5 \mathrm{lbs}$.

End Shape: Blunt

Comments: $\quad$ after impact the pipe was 119.13 in.

length, $3.5 \mathrm{in}$. diameter end shape

Launch Data:

Pressure: $\quad 38 \mathrm{psi}$

Missile Velocity $\quad 50 \mathrm{mph}$

Comments:

Impact Data:

Angle of Impact: $\quad 90^{\circ}$ - normal

Penetration: $\quad 0.69$ in.cavity oval shape 5 in. $x 7.5$ in.

Perforation: No

Back Face Scabbing: No

Description of Response:

No cracks on front face. Radical cracks on the back face.

Maximum width of radical cracks was $3 / 32$ in.

Documentation:

High Speed Movies: Fastax; front face through mirror -

CR -8.3

VHS Video: $\quad$ Front side - CR- 8.3

Still Photos: $\quad$ CR- 8.3-01 and CR $-8.3-02$ 


\section{DATA SHEET \\ TEST CR-9.1 \\ REINFORCED CONCRETE WALL \\ $1 / 16 / 90$}

Wall section:

Size:

39 in. $x 39$ in. concrete slab; 8

in. thick

Reinforcement: \#3's @ 12 in. o.c. each way each face, placed

1.5 in. away from each face

Edge Support: $\quad$ Simply supported on all four sides

Age: 70 days

Strength:

Average compressive - 4759 psi;

Average split tensile - 321 psi

Impact Point:

Center of slab

Comments:

Impact point located between reinforcing bars

Missile:

Material:

Schedule 40 steel pipe

Size:

3 in. nominal diameter; 3.5 in.

Weight: 79.0 lbs. outside diameter; $117.5 \mathrm{in}$. long

End Shape:

Blunt

Comments:

after impact the pipe was 117.38 in.

length, 3.25 in. $\times 3.75$ in.

oval end shape

Launch Data:

Pressure: $\quad 38 \mathrm{psi}$

Missile Velocity $\quad 50 \mathrm{mph}$

Comments:

Impact Data:

Angle of Impact: $\quad 90^{\circ}$ - normal

Penetration:

0.44 in.; cavity oval shape 5 in. $x 6.5$ in.

Perforation:

No

Back Facc Scabbing: No

Description of Response:

No cracks on front face. Radical hairline cracks on the back face.

Since there was virtually no damage from this impact, it was

decided to test again with a second shot. (see CR-9.2)

Documentation:

High Speed Movies: $\quad$ No

VHS Video: $\quad$ Front side - CR- 9.1

Still Photos: $\quad$ CR- 9.1-01 and CR - 9.1-02 


\section{DATA SHEET \\ TEST CR-9.2 \\ REINFORCED CONCRETE WALL \\ $2 / 1 / 91$}

Wall section:

Size:

39 in. $x 39$ in. concrete slab; 9

in. thick

Reinforcement: \#4's@12 in. o.c. each way each face, placed

1.5 in. away from each face

Edge Support: $\quad$ Simply supported on all four sides

Age:

113 days

Strength:

Average compressive - 4759 psi;

Impact Point: $\quad$ Center of slab

Comments: Impact point located between reinforcing bars

Missile:

Material: $\quad$ Schedule 40 steel pipe

Size: $\quad 3$ in. nominal diameter; 3.5 in.

Weight: $\quad 76.5 \mathrm{lbs}$.

End Shape: Blunt

Comments: after impact the pipe was $116.5 \mathrm{in}$.

length, 4.00 in. $x 3.75$ in.

oval end shape

Launch Data:

$\begin{array}{ll}\text { Pressure: } & 69 \mathrm{psi} \\ \text { Missile Velocity } & 78 \mathrm{mph}\end{array}$

Missile Velocity $\quad 78 \mathrm{mph}$

Comments:

Impact Data:

Angle of Impact: $\quad 90^{\circ}$ - normal

Penetration: $\quad 1.50$ in; cavity oval shape 9.5 in. $x 10.0$ in.

Perforation: No

Back Face Scabbing: Impact speed appears to be at threshold of scabbing; small 1 in.

$\mathrm{x} 0.5$ in. fragments were dislodged

from back face.

Description of Response:

No cracks on front face. Radical hairline cracks on the back face;

radical cracks $3 / 16$ in. width on back face.

Documentation:

High Speed Movies: No

VHS Video: $\quad$ Front side - CR- 9.2

Still Photos: $\quad$ CR- 9.2- 01 and CR $-9.2-02$ 


\section{DATA SHEET \\ TEST CR-10.1 \\ REINFORCED CONCRETE WALL \\ $2 / 1 / 91$}

Wall section:

Size:

39 in. $x 39$ in. concrete slab; 10

in. thick

Reinforcement: \#4's@12 in. o.c. each way each face, placed

1.5 in. away from each face

Edge Support: $\quad$ Simply supported on all four sides

Age: 113 days

Strength: $\quad$ Average compressive -4759 psi;

Impact Point: $\quad$ Center of slab

Comments: Impact point located between reinforcing bars

Missile:

Material: $\quad$ Schedule 40 steel pipe

Size: $\quad 3$ in. nominal diameter; $3.5 \mathrm{in.}$

Weight: $\quad 73.5 \mathrm{lbs}$.

End Shape: Blunt

Comments: $\quad$ after impact the pipe was $114.88 \mathrm{in}$.

length, 5.00 in. $x 3.75$ in.

oval end shape

Launch Data:

Pressure: $\quad 67 \mathrm{psi}$

Missile Velocity $\quad 74 \mathrm{mph}$

Comments:

Impact Data:

Angle of Impact: $\quad 90^{\circ}$ - normal

Penetration: $\quad 0.81 \mathrm{in}$; cavity oval shape 5.5 in. $\times 7.5$ in.

Perforation: No

Back Face Scabbing: No

Description of Response:

No cracks on front face. Radical hairline cracks on the back face.

Documentation:

High Speed Movies: No

VHS Video: $\quad$ Front side - CR- 10.1

Still Photos: $\quad$ CR- 10.1-01 and CR - 10.1-02 


\section{DATA SHEET \\ TEST CBM - (9.5).1 \\ REINFORCED BRICK CAVITY WALL $1 / 18 / 91$}

Wall section:

Size:

52 in. $x 48$ in. CMU block wall; 9.5

in. thick

Reinforcement:

Cavity filled with grout and \#4

rebar placed vertically 8 in. o.c.;

truss-type horizontal joint

reinforcement placed every $5^{\text {th }}$

course (16 in. o.c. vertically)

Edge Support: $\quad$ Simply supported on all four sides

Age: $\quad 77$ days

Strength: $\quad$ Average compressive - 4759 psi;

Impact Point: $\quad$ Center of wall

Comments: $\quad$ Impact point $5.0 \mathrm{in}$. left of center

but still between vertical rebar

Missile:

Material:

Size:

Schedule 40 steel pipe

3 in. nominal diameter; 3.5 in. outside diameter; 119.00 in. long

Weight: $\quad 79.0 \mathrm{lbs}$.

End Shape: Blunt

Comments: $\quad$ after impact the pipe was 118.88 in.

length, 3.50 in. $x 3.75$ in.

oval end shape

Launch Data:

Pressure: $\quad 38$ psi

Missile Velocity $\quad 50 \mathrm{mph}$

Comments:

Impact Data:

Angle of Impact: $\quad 90^{\circ}$ - normal

Penetration:

1.13 in; cavity oval shape 8.0 in. $x 5.0$ in.

Perforation:

No

Back Face Scabbing: No

Description of Response:

Hairline cracks on front face; vertical crack on back

face with maximum width of 0.25 in.

Documentation:

High Speed Movies: Fastax; left profile through mirror; CBM - (9.5). 1

VHS Video:

Front side - CBM - (9.5).1

Still Photos:

CBM - (9.5)- 01 and CBM - (9.5) - 02 


\section{DATA SHEET \\ TEST CBCMU - 12.1 \\ COMBINED CMU BLOCK AND BRICK VENEER WALL \\ $1 / 22 / 91$}

Wall section:

Size:

48 in. $x 48$ in. combined CMU

block wall; ( 8 in. thick) with one

wythe brick veneer on front face;

total thickness of wall was 12 in.

Reinforcement: $\quad$ Each vertical cell reinforced with one 4 in. rebar (8 in. 0.c.); each vertical cell filled with grout; truss-type horizontal joint reinforcement placed every other course (16 in. o.c. vertically)

Edge Support: Simply supported on all four sides

Age: 81 days

Strength: Average compressive: (grouted CMU) 3911 psi, (brick) 4720 psi

Impact Point: $\quad$ Center of wall

Comments:

Impact point located between reinforcing bars

Missile:

Material:

Size:

Weight:

End Shape:

Comments:
Schedule 40 steel pipe

3 in. nominal diameter; 3.5 in. outside diameter; 117.00 in. long 77.0 lbs.

Blunt

after impact the pipe was 116.88 in. length, 3.25 in. $x 3.75$ in. oval end shape

$38 \mathrm{psi}$

$50 \mathrm{mph}$

Pressure:

Missile Velocity

Comments:

Impact Data:

Angle of Impact:

$90^{\circ}$ - normal

Penetration:

2.13 in.

Perforation:

No

Back Face Scabbing:

Impact speed appears to be vary to threshold of back face scabbing (See Figure 31b)

Description of Response:

$3 / 8$ in. vertical crack on back face propagated through wall; brick at top course of wall

became dislodged

Documentation:

High Speed Movies: No

VHS Video:

Front side - CBCMU- 12.1

Still Photos:

CBCMU - 12.1- 01 and CBCMU- $12.1-02$ 


\section{DATA SHEET \\ TEST CMU - 12.1 \\ REINFORCED CMU BLOCK WALL \\ $1 / 29 / 91$}

Wall section:

Size:

Reinforcement:

48 in. $x 48$ in. CMU block wall; 12

in. thick

Each vertical cell reinforced with one 4 in. rebar ( 8 in. o.c.); each vertical cell filled with grout; truss-type horizontal joint reinforcement placed every other course (16 in. o.c. vertically)

Edge Support: $\quad$ Simply supported on all four sides

Age:

88 days

Strength:

Impact Point:

Average compressive - 3911 psi;

Center of wall (intended)

Comments:

Impact point moved 3.5 in. due missile striking rebound guard, but still between vertical rebar

Missile:

Material:

Size:

Weight:

End Shape:

Comments:

Schedule 40 steel pipe

3 in. nominal diameter; 3.5 in. outside diameter; 116.13 in. long 73.5 lbs.

Blunt

After impact the pipe was $116.00 \mathrm{in}$. length, $3.50 \mathrm{in.} \times 3.75 \mathrm{in}$. oval end shape

Launch Data:

Pressure:

Missile Velocity

Comments:

65 psi

Not recorded

Pipe struck metal rebound guard due to recoil. After striking guard, missile hit barrier at known impact speed estimate at least than $20 \mathrm{mph}$

Impact Data:

Angle of Impact: $\quad 90^{\circ}$ - normal

Penetration: $\quad 0.50$ in.

Perforation: No

Back Face Scabbing: No

Description of Response:

$1 / 8$ in. vertical crack on back face which propagated to the front face

Documentation:

High Speed Movies: No

VHS Video: $\quad$ Front side - CMU - 12.1

Still Photos: $\quad$ CMU $-12.1-01$ and CMU $-12.1-02$ 


\section{DATA SHEET \\ TEST CMU - 12.2 \\ REINFORCED BRICK CAVITY ROOF \\ $1 / 29 / 91$}

Wall section:

Size:

48 in. $x 48$ in. CMU block wall; 12 in. thick

Reinforcement:

Each vertical cell reinforced with one 4 in. rebar ( 8 in. o.c.);

each

vertical cell filled with grout; truss-type horizontal joint

Edge Support: reinforcement placed every other course (16 in. o.c. vertically)

Age: Simply supported on all four sides

Strength: 89 days Impact Point: Average compressive - 3911 psi; Center of wall

Commonts:

Impact point $6 \mathrm{in}$. left of center between reinforcing bars

Missile:

Material:

Schedule 40 steel pipe

Size:

Weight:

End Shape:

3 in. nominal diameter; 3.5 in. outside diameter; 115.75 in. long

$73.5 \mathrm{lbs}$.

Blunt

Comments:

After impact the pipe was 115.75 in. length, 3.50 in. $x 3.75$ in. oval end shape

Launch Data:

Pressure:

Missile Velocity

$50 \mathrm{psi}$

Comments:

$59 \mathrm{mph}$

Second Shot at wall

Impact Data:

Angle of Impact: $\quad 90^{\circ}$ - normal

Penetration:

$1.38 \mathrm{in}$.

Perforation: No

Back Face Scabbing: Yes, impact speed appears to be at threshold speed for scabbing

Description of Response:

Vertical cracks on front face and back face. Cracks

propagate through wall. Scabbing debris weighing $0.6 \mathrm{lbs}$.

Dislodged from back face. First shot at this wall (CMU-12.2)

did not appear to affect behavior to this second shot.

\section{Documentation:}

High Speed Movies: No

VHS Video:

Front side - CBM - 12.2

Still Photos:

CBCMU - 12.2- 01 and CMU-12.2 - 02 
APPENDIX $\mathrm{H}$

$2 \times 4$ TIMBER MISSILE IMPACTS ON

REINFORCED CONCRETE

H-1 
In 1989, two 4 in. and one 6 in. reinforced concrete slabs were impacted by $2 \times 4$ timber missiles in the Texas Tech Tornado Missile Impact Facility. The barriers, which had the same concrete mix design as the barriers used for the steel pipe missile tests, were all impacted in the center of the slab where no reinforcement was placed. One 4 in. slab was impacted by a $122 \mathrm{mph}$ timber. It suffered a large vertical crack that propagated through the slab. The slab had no reinforcement. The other 4 in. slab was impacted twice. In the first test, the $2 \times 4$ timber impacted at the speed of $121 \mathrm{mph}$. The slab experienced no damaged but the $2 \times 4$ timber was reduced to splinters. In the second test, the slab was impacted at a speed of $147 \mathrm{mph}$. The $2 \times 4$ timber disintegrated into splinters and only hairline cracks were found on the slab's back face. This slab was reinforced with \#3's at 6 in. on center, each way and placed in the middle of the slab. The last test was performed on a 6 in. reinforced slab. The reinforcement again consisted of \#3's 6 in. on center, each way and placed in the middle of the slab. Again, the impact reduced the $2 \times 4$ timber to splinters and the slab sustained no damage. These tests are detailed in the following test data sheets. 


\section{DATA SHEET \\ 4 in. CONCRETE SLAB \\ $11 / 89$}

Wall section:

Size:

36 in. $x$ 36in. concrete slab; 4

in. thick

Reinforcement: \#3's @ 6 in. o.c. each way placed in the middle of slab

Strength:

Average compressive - 4980 psi;

Impact Point:

Center of slab

Comments:

Impact point located

between reinforcing bars

Missile:

Material:

$2 \times 4$ timber, Douglas fir

Size:

Weight:

141.0 in. long

End Shape:

$13.5 \mathrm{lbs}$.

Comments:

Blunt

Launch Data:

Pressure:

$53 \mathrm{psi}$

Missile Velocity $\quad 122 \mathrm{mph}$

Comments:

Impact Data:

Angle of Impact: $\quad 90^{\circ}$ - normal

Penetration: No

Perforation: No

Back Face Scabbing: No

Description of Response:

Vertical cracks on back face propagate through the slab.

Width of vertical crack was 0.25 . the $2 \times 4$ timber

was reduced to splinters

Documentation:

High Speed Movies: No

VHS Video: No

Still Photos: $\quad$ Yes 


\section{DATA SHEET \\ 4 in. REINFORCED CONCRETE SLAB \\ $1^{\text {st }}$ TEST \\ $11 / 89$}

Wall section:

Size:

36 in. $x$ 36in. concrete slab; 4 in. thick

Reinforcement:

\#3's @ 6 in. o.c. each way placed in the middle of slab

Strength:

Impact Point:

Average compressive - $4980 \mathrm{psi}$;

Comments:

Center of slab

Impact point located between reinforcing bars

Missile:

Material:

Size:

Weight:

End Shape:

Comments:

$2 \times 4$ timber, Douglas fir

$141.0 \mathrm{in.}$ long

$13.5 \mathrm{lbs}$.

Blunt

Launch Data:

Pressure:

Missile Velocity

$53 \mathrm{psi}$

Comments:

Impact Data:

$\begin{array}{ll}\text { Angle of Impact: } & 90^{\circ} \text {-normal } \\ \text { Penetration: } & \text { No } \\ \text { Perforation: } & \text { No } \\ \text { Back Face Scabbing: } & \text { No }\end{array}$

Description of Response:

Slab suffered no damage. The $2 \times 4$ timber was reduced to splinters.

Documentation:

High Speed Movies: No

VHS Video: No

Still Photos: Yes 


\section{DATA SHEET \\ 4 in. REINFORCED CONCRETE SLAB \\ $2^{\text {nd }}$ TEST \\ $11 / 89$}

Wall section:

Size:

36 in. $x$ 36in. concrete slab; 4

in. thick

Reinforcement: \#3's @ 6 in. o.c. each way placed in the middle of slab

Strength:

Impact Point:

Average compressive - 4980 psi;

Comments:

Center of slab

Impact point located

between reinforcing bars

Missile:

Material: $\quad 2 \times 4$ timber, Douglas fir

Size:

Weight:

$14.25 \mathrm{lbs}$.

142.5 in. long

End Shape:

Blunt

Comments:

Launch Data:

Pressure:

Missile Velocity

Comments:

64 psi

$147 \mathrm{mph}$

Impact Data:

Angle of Impact: $\quad 90^{\circ}$-normal

Penetration: No

Perforation: No

Back Face Scabbing: No

Description of Response:

Hairline cracks on slab's back face. The $2 \times 4$ timber

was reduced to splinters

Documentation:

High Speed Movies: No

VHS Video:

No

Still Photos:

Yes 


\section{DATA SHEET \\ 4 in. REINFORCED CONCRETE SLAB \\ $12 / 89$}

Wall section:

Size:

36 in. $x$ 36in. concrete slab; 4

in. thick

Reinforcement:

\#3's @ 6 in. o.c. each way placed in the middle of slab

Strength:

Impact Point:

Comments:

Average compressive - 4980 psi;

Center of slab

Impact point located between reinforcing bars

Missile:

Material:

Size:

Weight:

End Shape:

Comments:

Launch Data:

Pressure:

$71 \mathrm{psi}$

Missile Velocity

$2 \times 4$ timber, Douglas fir

143.0 in. long

13.75 lbs.

Blunt

Comments:

Impact Data:

Angle of Impact: $\quad 90^{\circ}$ - normal

Penetration: No

Perforation: No

Back Face Scabbing: No

Description of Response:

Slab suffered no damage. The $2 \times 4$ timber was reduced to splinters

Documentation:

High Speed Movies: No

VHS Video: No

Still Photos: Yes 
APPENDIX I

PERCENT STEEL CALCULATIONS FOR

REINFORCED CONCRETE PANELS 
Each 39 in. slab contained approximately the minimum amount of reinforcement as specified by ACI 318-89. This minimum amount was $0.50 \%$. Table 10 gives the percent reinforcement for each slab tested.

Table I-1. Percent Reinforcement

\begin{tabular}{|l|l|c|}
\hline \multicolumn{1}{|c|}{ SLAB THICKNESS } & REINFORCEMENT & \% of STEEL \\
\hline CR-6.1: 6 in. Slabs & \#3's @ 9 in. o.c. each way & 0.54 \\
\hline CR-6.2: 6 in. Slab & \#4's @ 12 in. o.c. each way & 0.61 \\
\hline CR-6.3: 6 in. Slab & \#3's @ 9 in. o.c. each way & $0.41^{*}$ \\
\hline CR-8.1: 8 in. Slab & \#4's @ 9 in. o.c. each way & 0.54 \\
\hline CR-8.2: 8 in. Slab & \#4's @ 12 in. o.c. each way & $0.41^{*}$ \\
\hline CR-8.3: 8 in. Slab & \#3's @ 12 in. o.c. cach way & 0.73 \\
\hline CR-9.(1\&2): 9 in. Slab & \#4's @ 12 in. o.c. each way & 0.65 \\
\hline CR-10.1: 10 in. Slab & \#4's @ 12 in. o.c. each way & \\
\hline
\end{tabular}

Slabs with slightly less than minimum reinforcing according to $\mathrm{ACI}$ requirements performed as well as those with equal or greater amounts than the minimum. 
APPENDIX $\mathrm{J}$

CALIBRATION OF TIMERS 
Two timers record the missile velocity as the trailing end passes through the timing gate. To ensure accuracy of these timers, calibration tests are routinely conducted. An oscilloscope is used to independently measure the missile exit velocity. Oscilloscope leads are attached to one pair of photo cells. A short missile is fired and both the oscilloscope and one of the timers record the elapsed time through the gate in milli-seconds. The two measurements are compared and the percent difference is calculated. The test is repeated for the other timer. Table J-1 presents calibration test results made prior to the series of tests described. The percent difference in all cases is less than $3.6 \%$. 